\title{
AVAILABILITY AND QUALITY OF WATER FROM THE ALLUVIAL, GLACIAL-DRIFT, AND DAKOTA AQUIFERS AND WATER USE IN SOUTHWEST IOWA
}

by R.E. Hansen, C.A. Thompson, and P.E. VanDorpe

\section{U.S. GEOLOGICAL SURVEY}

Water-Resources Investigations Report 91-4156

Prepared in cooperation with the IOWA DEPARTMENT OF NATURAL RESOURCES, GEOLOGICAL SURVEY BUREAU

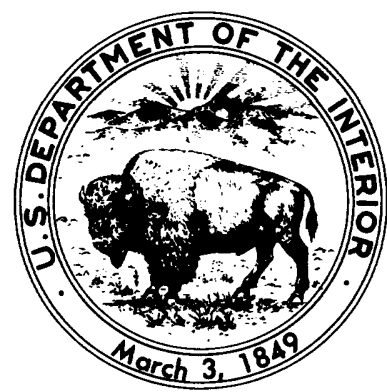

Iowa City, lowa 1992 


\section{U.S. DEPARTMENT OF THE INTERIOR \\ MANUEL LUJAN, JR., Secretary}

U.S. GEOLOGICAL SURVEY

Dallas L. Peck, Director

For additional information write to:

District Chief

U.S. Geological Survey

Rm. 269, Federal Building

400 South Clinton Street

Iowa City, Iowa 52244
Copies of this report can be purchased from:

U.S. Geological Survey

Open-File Reports

Earth Science Information Center

Box 25425

Denver, Colorado 80225 


\section{CONTENTS}

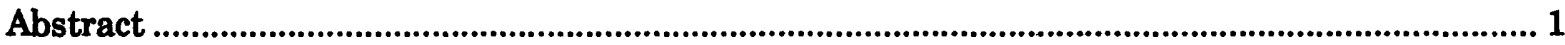

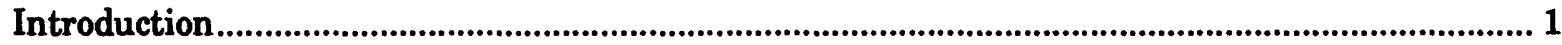

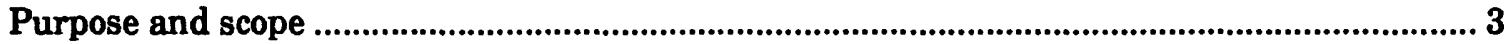

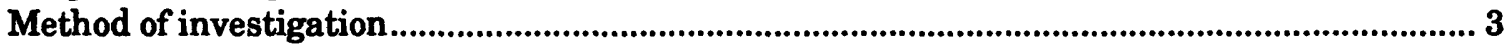

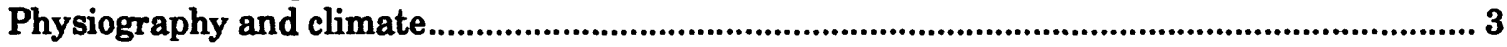

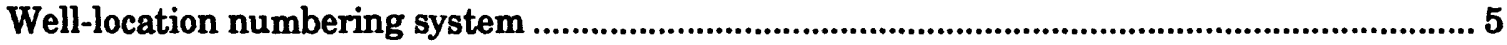

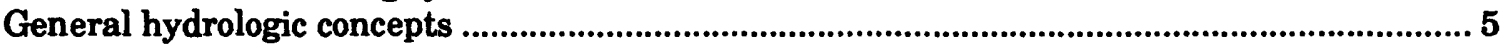

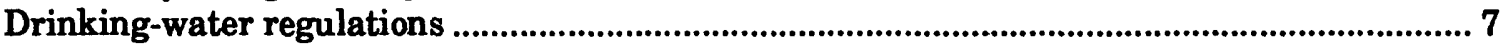

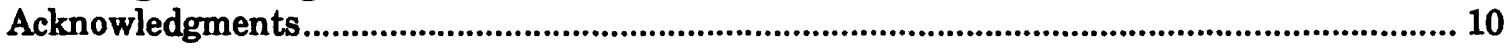

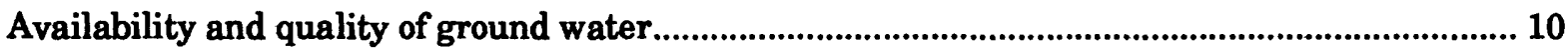

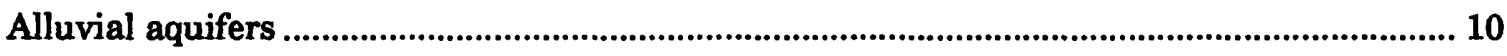

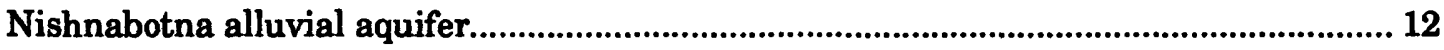

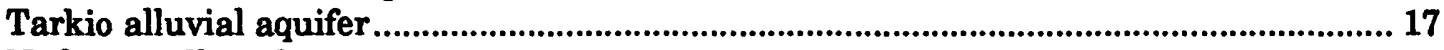

Nodaway alluvial aquifer............................................................................................................. 18

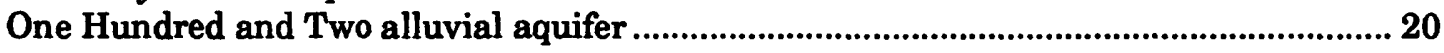

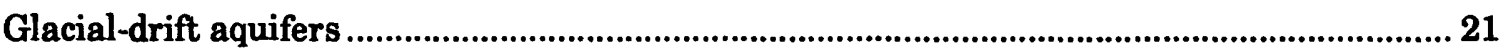

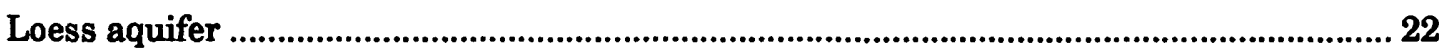

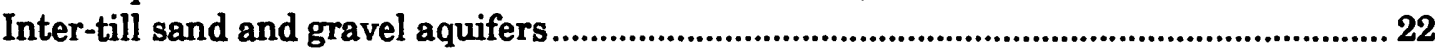

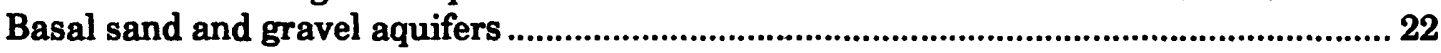

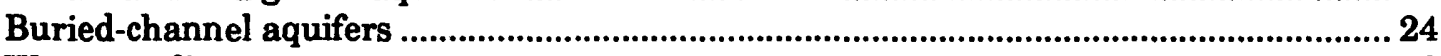

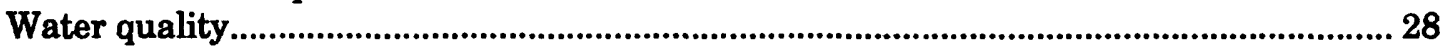

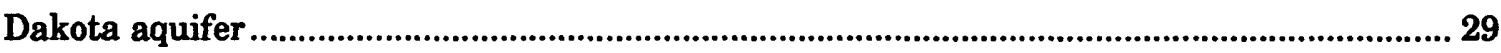

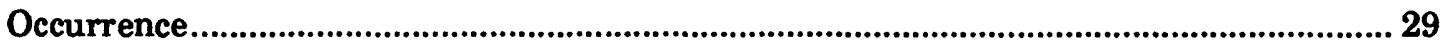

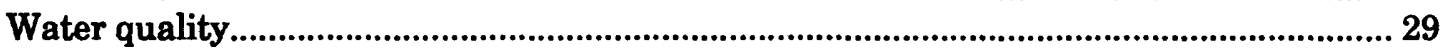

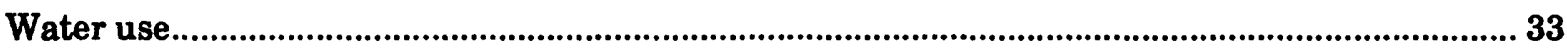

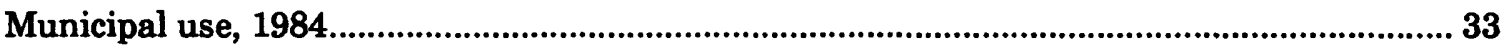

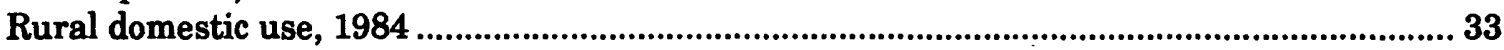

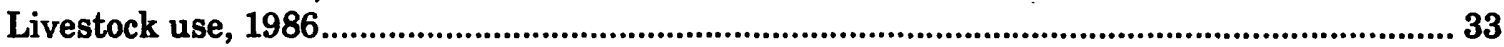

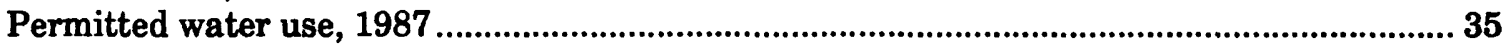

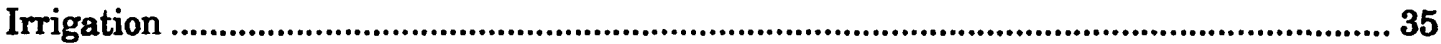

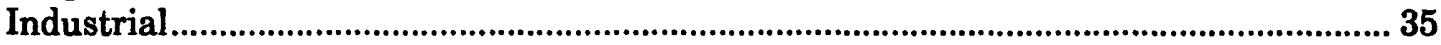

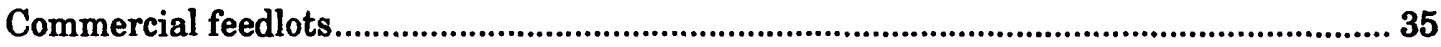

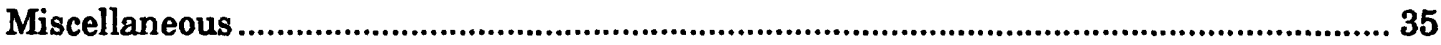

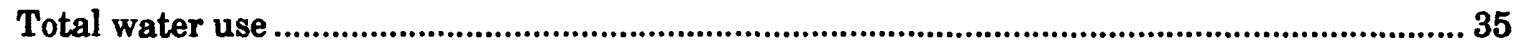

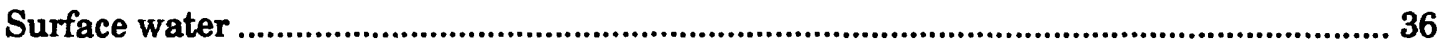




\section{CONTENTS--Continued}

Water use--Continued

Total water use--Continued

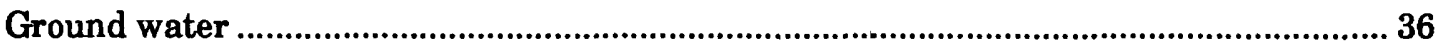

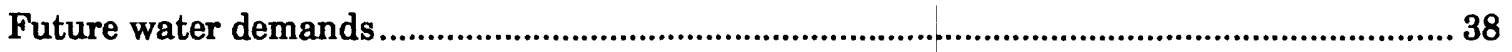

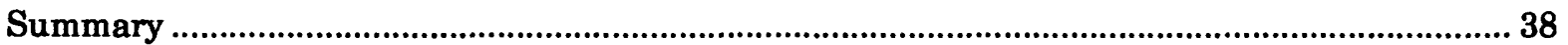

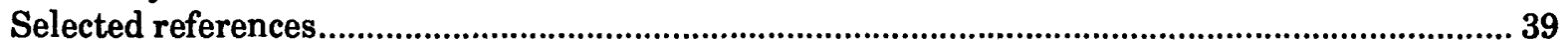

\section{ILLUSTRATIONS}

Figure 1. Map showing location of test holes and observation wells drilled from 1985 to 1987

2. Map showing landform regions .................................................................. 4

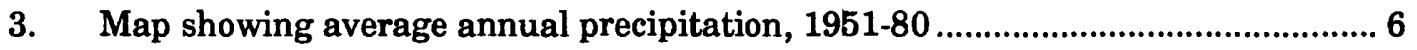

4. Graphs of average monthly temperature and precipitation at Red Oak, 1951-80

5. Diagram of well-location numbering system ..................................................... 8

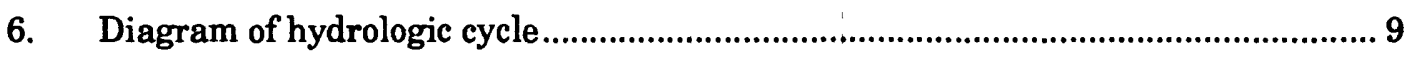

7. Diagram of east-west hydrogeologic section across study area ............................ 11

8. Diagram showing relation between nonpumping and pumping water levels

9. Map showing location of alluvial valleys and test holes and observation wells

10. Graphs of water levels in selected alluvial-aquifer wells, precipitation at Red Oak, and streamflow in the East Nishnabotna River at Red Oak.....

11. Piper diagram of mean water quality in the Nishnabotna alluvial aquifer ........ 16

12. Piper diagram of mean water quality in the Tarkio, Nodaway, and One Hundred and Two alluvial aquifers

Figures 13-18. Maps showing:

13. Altitude and thickness of inter-till sand and gravel deposits..............................23

14. Altitude and thickness of basal sand and gravel deposits ................................. 25

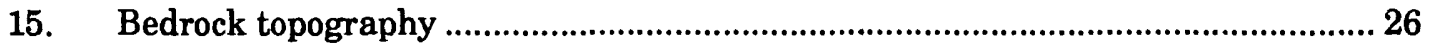




\section{ILLUSTRATIONS--Continued}

Figures 13-18. Maps showing:--Continued

16. Extent and thickness of the Fremont and Albany buried-channel aquifers 27

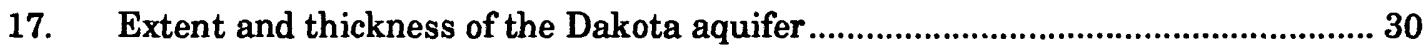

18. Potentiometric surface of the Dakota aquifer, 1986-88 ..................................... 31

19. Piper diagram of historical water quality of the Dakota aquifer, $1950-86 \ldots \ldots . . . .32$

20. Map showing average daily municipal water use and source of water

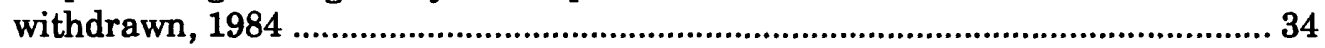

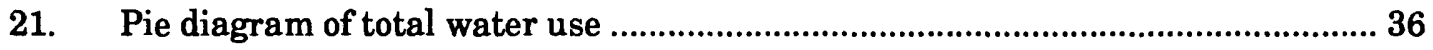

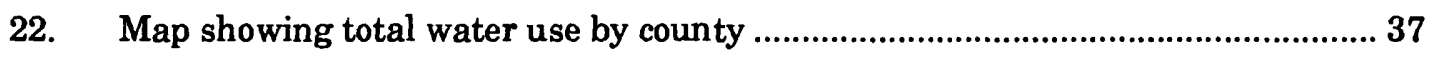

\section{TABLES}

Table 1. Geologic logs of test holes and observation wells drilled in southwest Iowa, 1985-87

2. Ranges of hydraulic conductivity of selected earth materials

3. U.S. Environmental Protection Agency drinking-water regulations

4. Health advisory and risk-assessment concentrations for selected pesticides in drinking water

5. Summary of nitrate analyses of samples from private wells, 1981-86

6. Stratigraphic units in the study area

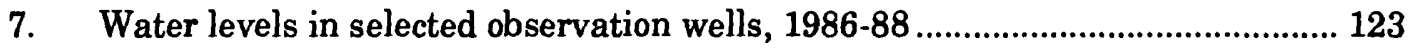

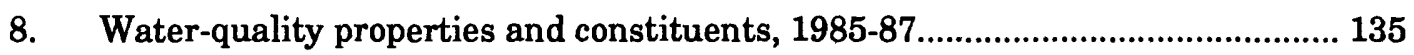

9. Concentrations of dissolved trace elements in selected wells, $1985-87$.............. 150

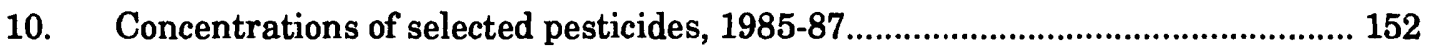

11. Statistical summary of historical, 1950-86, water-quality properties and constituents for alluvial aquifers.....

12. Selected pesticide analyses for water samples from the Nishnabotna River system, 1985-87.

13. Selected pesticide analyses for water samples from the Tarkio, Nodaway, and One Hundred and Two River systems, 1986-87 


\section{TABLES--Continued}

Table 14. Thickness of glacial drift in southwest Iowa ................................................ 169

15. Water levels and potential yields of the Dakota aquifer..................................... 170

16. Statistical summary of historical, 1950-86, water-quality properties and constituents and trace-element and radionuclide concentrations for nine municipalities using the Dakota aquifer

17. Water use by category, 1984

18. Water source and use for municipal and rural-water systems in southwest Iowa.

\section{CONVERSION FACTORS AND VERTICAL DATUM}

\section{Multiply}

inch (in.)

inch per month (in/mo)

inch per year (in/yr)

foot (ft)

mile (mi)

acre

square mile $\left(\mathrm{mi}^{2}\right)$

gallon (gal)

acre-foot (acre-ft)

cubic foot per second $\left(\mathrm{ft}^{3} / \mathrm{s}\right)$

gallon per minute (gal/min)

gallon per day (gal/d)

million gallons per day (Mgal/d)

foot squared per day $\left(\mathrm{ft}^{2} / \mathrm{d}\right)$
By

25.40

25.40

25.40

0.3048

1.609

0.4047

2.590

3.785

1,233

0.02832

0.06309

0.003785

0.04381

0.09290
To obtain

millimeter (mm)

millimeter per month $(\mathrm{mm} / \mathrm{mo})$

millimeter per year $(\mathrm{mm} / \mathrm{yr})$

meter (m)

kilometer (km)

hectare

square kilometer $\left(\mathrm{km}^{2}\right)$

liter (L)

cubic meter $\left(\mathrm{m}^{3}\right)$

cubic meter per second $\left(\mathrm{m}^{3} / \mathrm{s}\right)$

liter per second $(\mathrm{L} / \mathrm{s})$

cubic meter per day $\left(\mathrm{m}^{3} / \mathrm{d}\right)$

cubic meter per second $\left(\mathrm{m}^{3} / \mathrm{s}\right)$

meter squared per day $\left(\mathrm{m}^{2} / \mathrm{d}\right)$

Temperature in degrees Fahrenheit $\left({ }^{\circ} \mathrm{F}\right)$ can be converted to degrees Celsius $\left({ }^{\circ} \mathrm{C}\right)$ as follows:

$$
{ }^{\circ} \mathrm{C}=5 / 9 \times\left({ }^{\circ} \mathrm{F}-32\right) \text {. }
$$

Sea level: In this report, "sea level" refers to the National Geodetic Vertical Datum of 1929--a geodetic datum derived from a general adjustment of the first-order level nets of the United States and Canada, formerly called Sea Level Datum of 1929. 


\title{
AVAILABILITY AND QUALITY OF WATER FROM THE ALLUVIAL, GLACIAL-DRIFT, AND DAKOTA AQUIFERS AND WATER USE IN SOUTHWEST IOWA
}

\author{
by
}

\author{
R.E. Hansen ${ }^{1}$, C.A. Thompson ${ }^{2}$, and P.E. VanDorpe $^{2}$
}

\section{ABSTRACT}

A ground-water resources investigation was conducted in southwest lowa to describe the availability, quality, and use of water from the alluvial, glacial-drift, and Dakota aquifers in a nine-county area. Historical water quality was examined for each aquifer, and water samples were collected for major ions, trace metals, radionuclides, and selected pesticides. Selected aspects of surface-water resources in the study area also were examined to more fully evaluate alluvial aquifers. The flood plain of the Missouri River valley was not included except for the accounting of the water use in the area.

Four principal alluvial aquifers consisting of sand and gravel deposits in the valleys of the Nishnabotna, Tarkio, Nodaway, and One Hundred and Two Rivers are present. Yields to wells have been reported as large as 2,000 gallons per minute; however, most yields are less than 100 gallons per minute. Nitrate concentrations greater than the drinking-water regulation and agricultural herbicides have been detected in 6 of 27 samples from municipal water supplies.

Four types of glacial-drift aquifers are present--loess, inter-till sand and gravel, basal sand and gravel, and buried-channel aquifers. The glacial-drift aquifers are most commonly used by rural water users or users that do not have access to alluvial aquifers. These aquifers are discontinuous and unpredictable in location. Hydraulic and water-quality data generally are unavailable for these aquifers. Wells completed in loess commonly yield less than 10 gallons per minute, although there are reports of yields as large as 20 gallons per minute. Yields of 10 to 120 gallons per minute appear to be possible for

1 U.S. Geological Survey, Iowa City, Iowa.

2 Iowa Department of Natural Resources, Geological Survey Bureau, Iowa City, Iowa. inter-till and basal sand and gravel aquifers. Yields of more than $\mathbf{1 5 0}$ gallons per minute are possible from some buried-channel aquifers.

The Dakota aquifer is comprised of bedrock of Cretaceous age and is present as erosional remnants and outliers in several counties, mainly Cass and Montgomery. Yields of more than 150 gallons per minute to wells completed in the Dakota aquifer have been reported, afthough yields of 20 gallons per minute or less are more typical. The drinking-water regulation for nitrate has been exceeded in some samples from the Dakota aquifer.

The quantity of water withdrawn for municipal, rural-domestic, livestock, and other permitted water users was determined for each of the three principal aquifer types. The total water use within the study area was about 91.8 million gallons per day; 35.3 percent was from alluvial ground-water sources. Alluvial aquifers supplied most of the water from ground-water sources. The largest use of water is for permitted irrigation purposes, mostly from the Missouri River alluvial aquifer.

\section{INTRODUCTION}

Many residents of southwest Iowa, a predominantly agricultural region, depend on ground water for municipal and domestic water supplies. The quality of water from deep bedrock aquifers limits the use of water from these aquifers for most purposes; however, water of acceptable quality is available from shallow aquifers. Although geographically widespread, the shallow aquifers are not found in all locations. The need for an improved understanding of the occurrence and availability of shallow ground-water resources of southwest Iowa has resulted in the hydrologic study of a nine-county area: Adair, Adams, Cass, Fremont, Mills, Montgomery, Page, Pottawattamie, and Taylor Counties (fig. 1). The study is the last of nine regional areal appraisals describing 


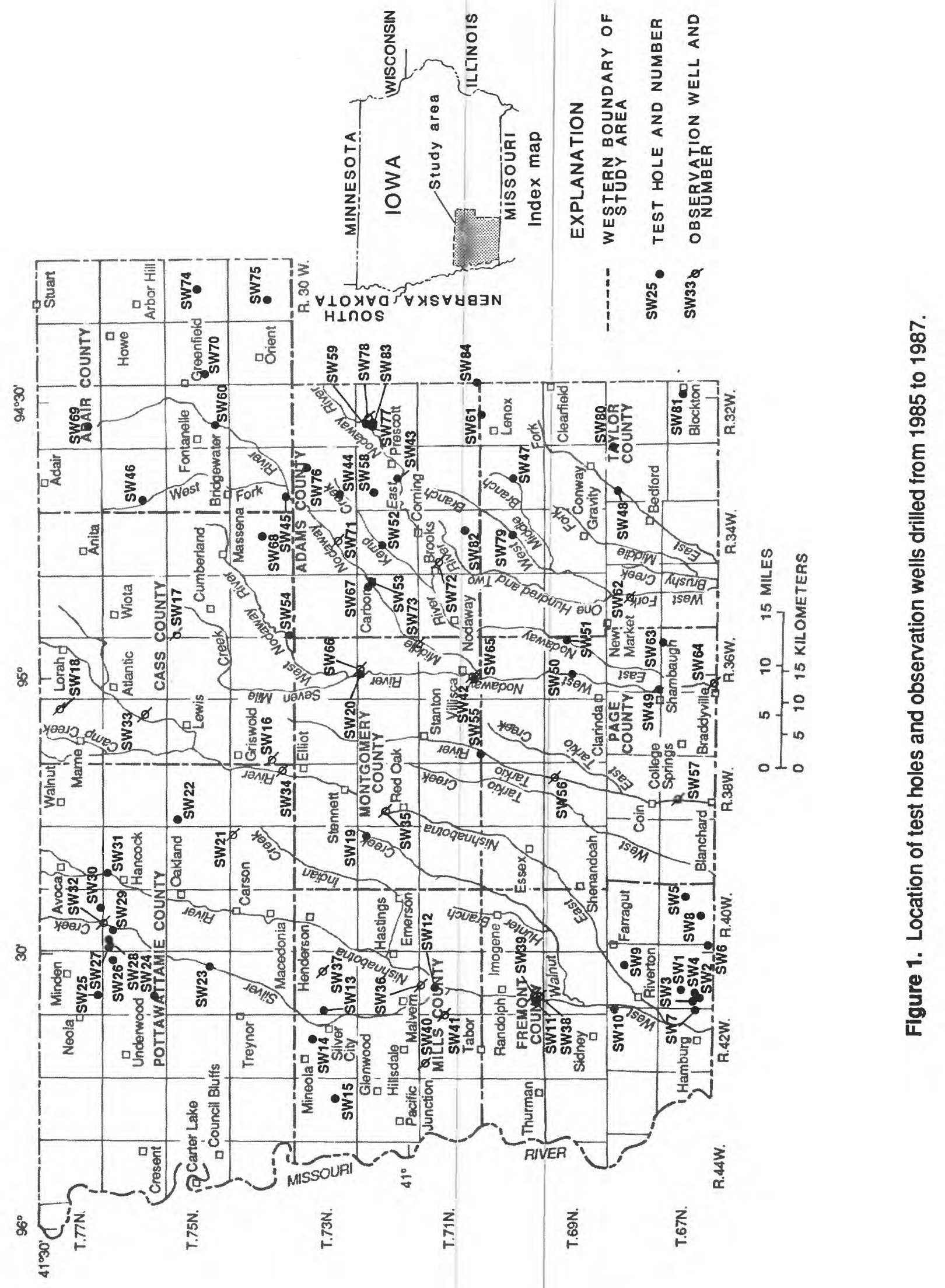


ground-water resources in Iowa. The study is part of a cooperative program between the U.S. Geological Survey and the Geological Survey Bureau of the Iowa Department of Natural Resources. The stratigraphic nomenclature used throughout this report is that of the Iowa Department of Natural Resources, Geological Survey Bureau.

\section{Purpose and Scope}

This report describes the availability and quality of ground water from the alluvial, glacial-drift, and Dakota aquifers, and water use in southwest Iowa. Specifically, the report describes: (1) the location and areal extent of the aquifers, (2) the occurrence of ground water, (3) the chemical quality of the water in the aquifers, and (4) the quantity of water withdrawn from these aquifers and surface-water sources for various uses.

This report contains a general appraisal of the ground-water resources in southwest Iowa and is intended to provide background information to aid in the development of ground-water supplies. Selected aspects of surface-water resources in the area were included as a means of evaluating the alluvial aquifers. The Missouri River alluvial aquifer is not included in this study because of the relatively large quantity of water available from it that is adequate for most uses. In addition, the Missouri River alluvial aquifer is presently (1989) used by only about 10 percent of the water users in southwest Iowa. However, for some categories of water use it was not practical to determine or estimate quantities of water derived from outside the study area. Therefore, water use is summarized for each county within the study area.

\section{Method of Investigation}

Historical records were examined, and observation-well drilling was used to obtain data for specific aquifers in areas where little or no ground-water information was available. Logs of the test holes and observation wells, along with well-construction details, are in table 1 at the back of this report, and locations are shown in figure 1. Observation wells were constructed to monitor water-level changes and to obtain samples of ground water for chemical analysis.
Surface-water samples also were collected at several sites for chemical analysis. Municipal water-use information was obtained from local water departments.

Water-quality data obtained from the University of Iowa Hygienic Laboratory, the U.S. Geological Survey, and the Iowa Department of Natural Resources were used to aid in the assessment of water quality in each of the aquifers. Water samples were collected during this study by U.S. Geological Survey personnel. All water samples were analyzed by the University of Iowa Hygienic Laboratory. Details of the analytical methods and quality-control procedures can be obtained from the laboratory.

\section{Physiography and Climate}

Three general landform regions are present in Iowa--the Southern Iowa Drift Plain, the Western Loess Hills, and the Missouri Alluvial Plain (Prior, 1976; fig. 2). The Western Loess Hills and the Missouri Alluvial Plain regions comprise about 20 percent of the land area in southwest Iowa. These narrow regions, about 3 to $10 \mathrm{mi}$ and 6 to $15 \mathrm{mi}$ wide, respectively, parallel the western side of the study area. Most of southwest Iowa lies within the Southern Iowa Drift Plain.

The Southern Iowa Drift Plain is a landscape of steeply rolling hills and incised valleys that has evolved since the end of the pre-Illinoian glaciation. Extensive erosion has removed many of the original glacial landforms and left a characteristic, multi-level, stepped-erosion landscape (Ruhe, 1969; Bettis and Littke, 1987). The Western Loess Hills region is characterized by a thick loess cover and sharply ridged terrain. The Missouri Alluvial Plain is a broad, low-lying, level region adjacent to the Missouri River.

The total area of southwest Iowa is $4,982 \mathrm{mi}^{2}$ or about 9 percent of the total area of the State. Maximum topographic relief is about $555 \mathrm{ft}$. The highest land-surface altitude is just over $1,460 \mathrm{ft}$, several miles north of Anita in Cass County, and the lowest altitude is about $905 \mathrm{ft}$ in the Missouri River valley at the southwest corner of the State.

The climate of southwest Iowa is subhumid. The average precipitation for southwest Iowa is $33.11 \mathrm{in} / \mathrm{yr}$ and varies from $31 \mathrm{in.}$ in the northwest to more than $35 \mathrm{in}$. in the southern 


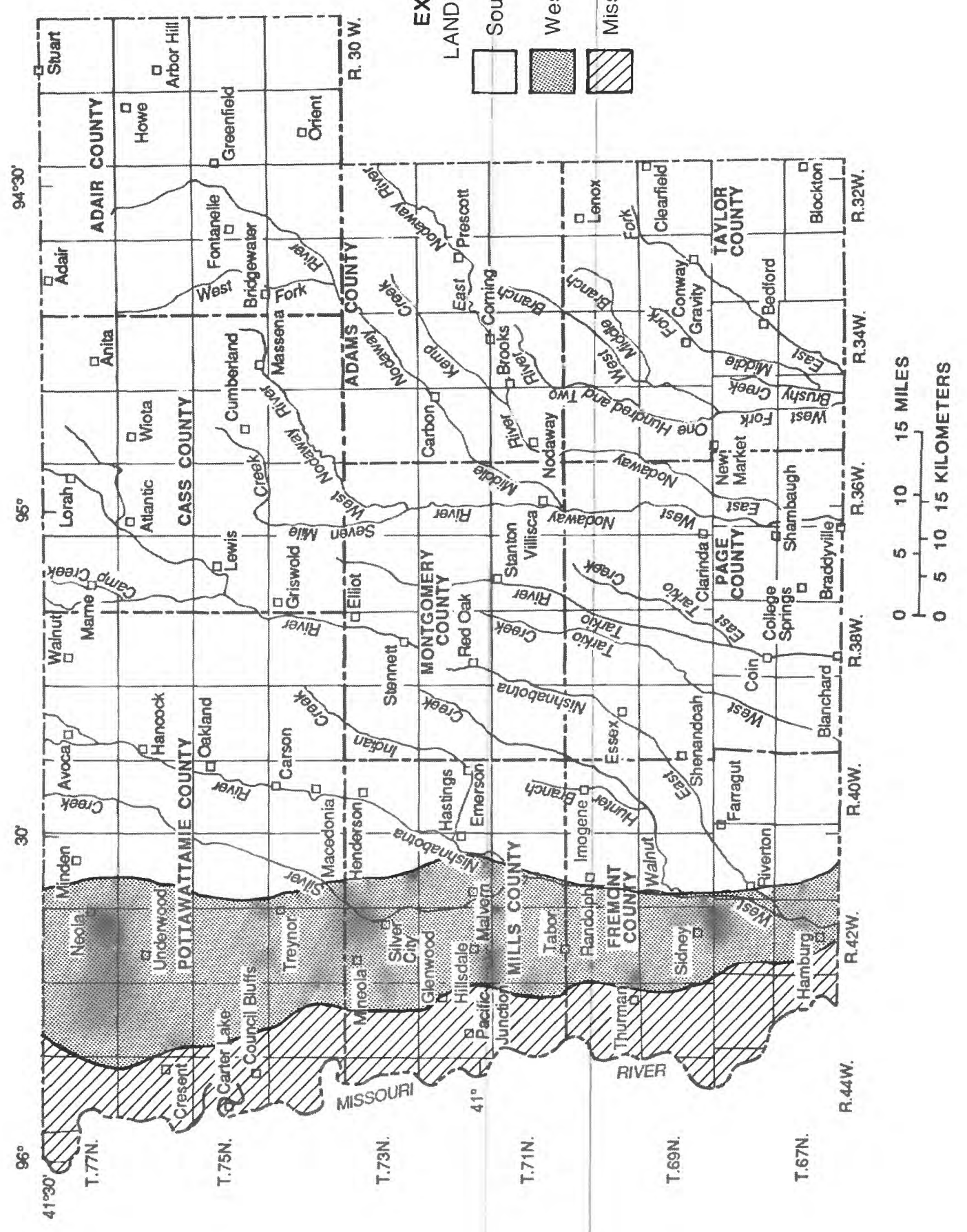


part of the study area (fig. 3). The period of greatest precipitation is during April through September (fig. 4). Average rainfall during this period is $4.3 \mathrm{in} / \mathrm{mo}$ at Red Oak in Montgomery County (National Oceanic and Atmospheric Administration, 1987). The average annual temperature for this area is $50.4{ }^{\circ} \mathrm{F}$ (National Oceanic and Atmospheric Administration, 1987). There is a large annual range in temperature (fig. 4); the hottest days occur in June, July, and August and the coldest in December, January, and February when the average monthly temperatures are below freezing.

\section{Well-Location Numbering System}

The wells and test holes referred to in this report are numbered according to a system of land survey in use by the U.S. Bureau of Land Management and the U.S. Geological Survey and is illustrated in figure 5. The first numeral denotes the township north of a base line, the second numeral denotes the range west of the fifth principal meridian, and the third numeral denotes the section in which the well is located. The letters A, B, C, and D designate the northeast, northwest, southwest, and southeast quarter of any area within a section. The first letter designates the location of the 160-acre quarter section; the second letter, the 40-acre quarter-quarter section; the third letter, the 10-acre quarter-quarter-quarter section; and the fourth letter, the 2.5-acre quarter-quarterquarter-quarter section. Consecutive terminal numerals are added if more than one well or test hole is recorded within a 2.5-acre tract. For example, well 68-35-15BCDD is located in the southeast quarter of the southeast quarter of the southwest quarter of the northwest quarter of section 15 in Township 68 North and Range 35 West.

\section{General Hydrologic Concepts}

The term hydrology encompasses the distribution, movement, and quality of water. Water is in continual circulation between open bodies of water, the atmosphere, and the land. This dynamic circulation system is called the hydrologic cycle (fig. 6). This cycle has no recognized beginning, but for descriptive purposes the atmosphere is an adequate starting point. Water vapor in the atmosphere condenses and falls to earth as precipitation. Once removed from the atmosphere, the water may follow several pathways within the hydrologic cycle. Much of the water may evaporate back into the atmosphere, some will pond or flow across the land surface, and some will infiltrate into the ground. Water on the land surface may evaporate to the atmosphere or infiltrate into the ground. Water in the ground may be evaporated or transpired by plants and returned to the atmosphere. Any excess water in the soil moves downward by gravity to where the soil or rock is saturated. The top of the saturated zone is called the water table. Water in the saturated zone moves through fractures and small openings between grains of soil and rock. The rate of movement of the water is controlled by the hydraulic conductivity of the material through which it moves and the hydraulic gradient. The water eventually moves to areas where it returns to the land surface and either enters the surface-runoff pathway or evaporates to the atmosphere, completing the cycle.

Hydraulic conductivity is a term used to express the ability of a material to transmit water. It is controlled, in part, by the size and connection between openings in earth materials. Gravel, well-sorted sand, poorly cemented sandstone, and fractured rocks generally have large hydraulic-conductivity values. These materials form aquifers. Fine-grained materials such as silt, clay, and shale usually have small hydraulic-conductivity values and retard ground-water movement. These materials form confining units. The potential range of hydraulic conductivities of some of the typical materials present in the study area is shown in table 2 at the back of this report. Transmissivity, a measure of the ability of an aquifer to transmit water through connected openings, is a product of the hydraulic conductivity and the aquifer thickness.

Water in aquifers overlain by confining units may rise by hydraulic pressure in wells to altitudes higher than the top of the aquifer. These aquifers are called artesian aquifers. The level to which water will rise in a well that penetrates an aquifer is called the potentiometric surface at that location. Generally, artesian aquifers occur at greater depths below the land surface than water-table aquifers. In a water-table aquifer, the upper water surface is in equilibrium with atmospheric pressure. 


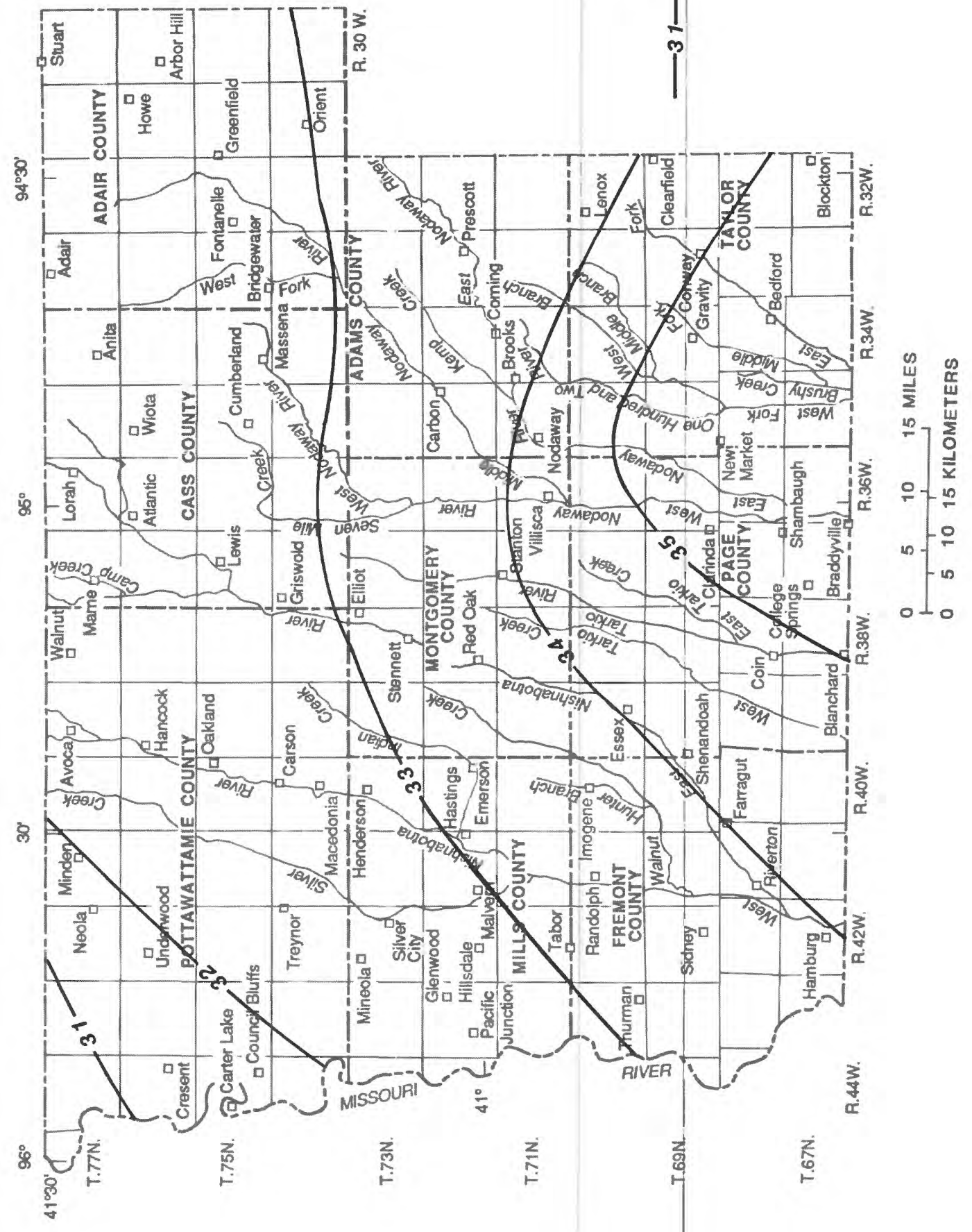

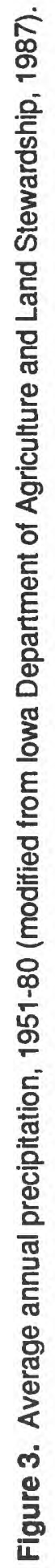



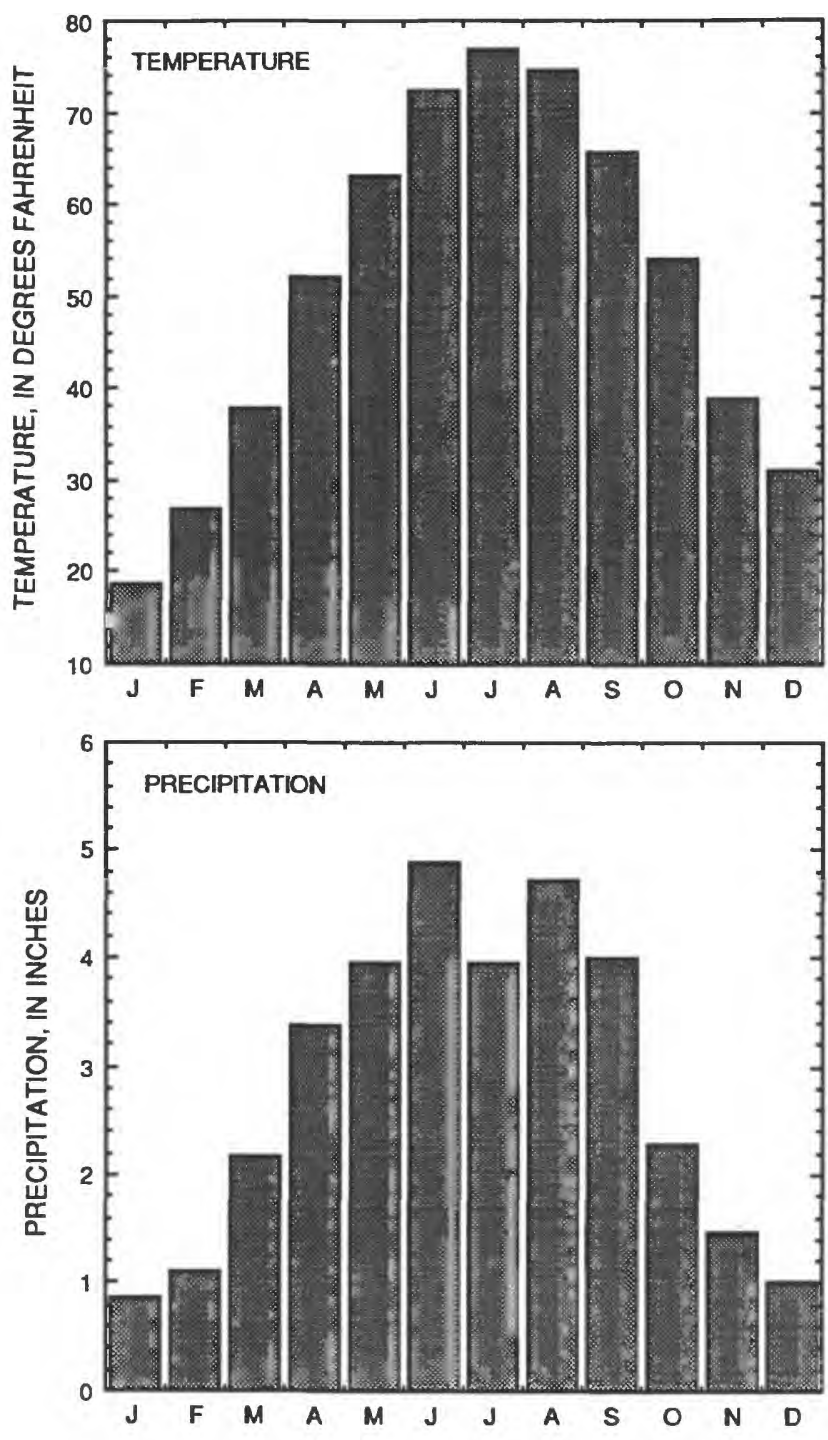

Figure 4. Average monthly temperature and precipitation at Red Oak, 1951-80 (data from National Oceanic and Atmospheric Administration, 1987).

Hydraulic gradient refers to the difference in water level between two points divided by the distance between the points. The movement of ground water is from areas of higher water level to areas of lower water level. The larger the gradient, the greater is the potential for flow to the point of lower water level. The most common method used to determine hydraulic gradients is to measure water levels in wells that penetrate the aquifer or aquifers of interest. Water-level altitudes then can be plotted and lines of equal water-level altitude drawn on a map. The direction of ground-water movement is downgradient and perpendicular to the lines of equal water-level altitude.
The water level in an aquifer fluctuates in response to recharge and discharge from the aquifer, usually indicating a change in the quantity of water stored in the aquifer. In Iowa, water-table aquifers near the land surface usually are recharged in the spring and fall by direct infiltration of precipitation or snowmelt. Recharge to these aquifers in the study area usually is sufficient to replace water losses caused by withdrawals from wells or natural ground-water movement. Aquifers that are confined by thick deposits of fine-grained materials are recharged at slow rates by leakage from above or below through the confining materials or by lateral movement of water through the aquifer from more distant recharge areas.

The suitability of ground water for various purposes is determined by the quantity of water available and by its chemical quality. As ground water moves through earth materials, it can dissolve minerals. In general, ground water becomes more mineralized with time and distance from the recharge area. Ground water in this report will be characterized by reference to the dominant anions and cations that it contains. Water is referred to as a cation-anion type, such as calcium-bicarbonate water. The dominant cations are calcium, magnesium, and sodium. The dominant anions are bicarbonate, sulfate, and chloride.

\section{Drinking-Water Regulations}

Public drinking-water regulations have been adopted by the U.S. Environmental Protection Agency as part of the Safe Drinking Water Act (PL 93-523). Primary regulations refer to Maximum Contaminant Levels (MCL), which are the maximum levels of contaminant permissible in a public-water supply. Secondary regulations apply to substances that affect aesthetic qualities of drinking water, such as taste and odor, and are not enforceable contaminant levels. In addition to aesthetic quality, health implications also may exist if considerably larger concentrations of the secondary-regulation substances occur. The National Drinking-Water Regulations are listed in table 3 at the back of this report.

Much of the current concern with regard to water quality in lowa has focused on agricultural chemicals, particularly nitrate and pesticides. 


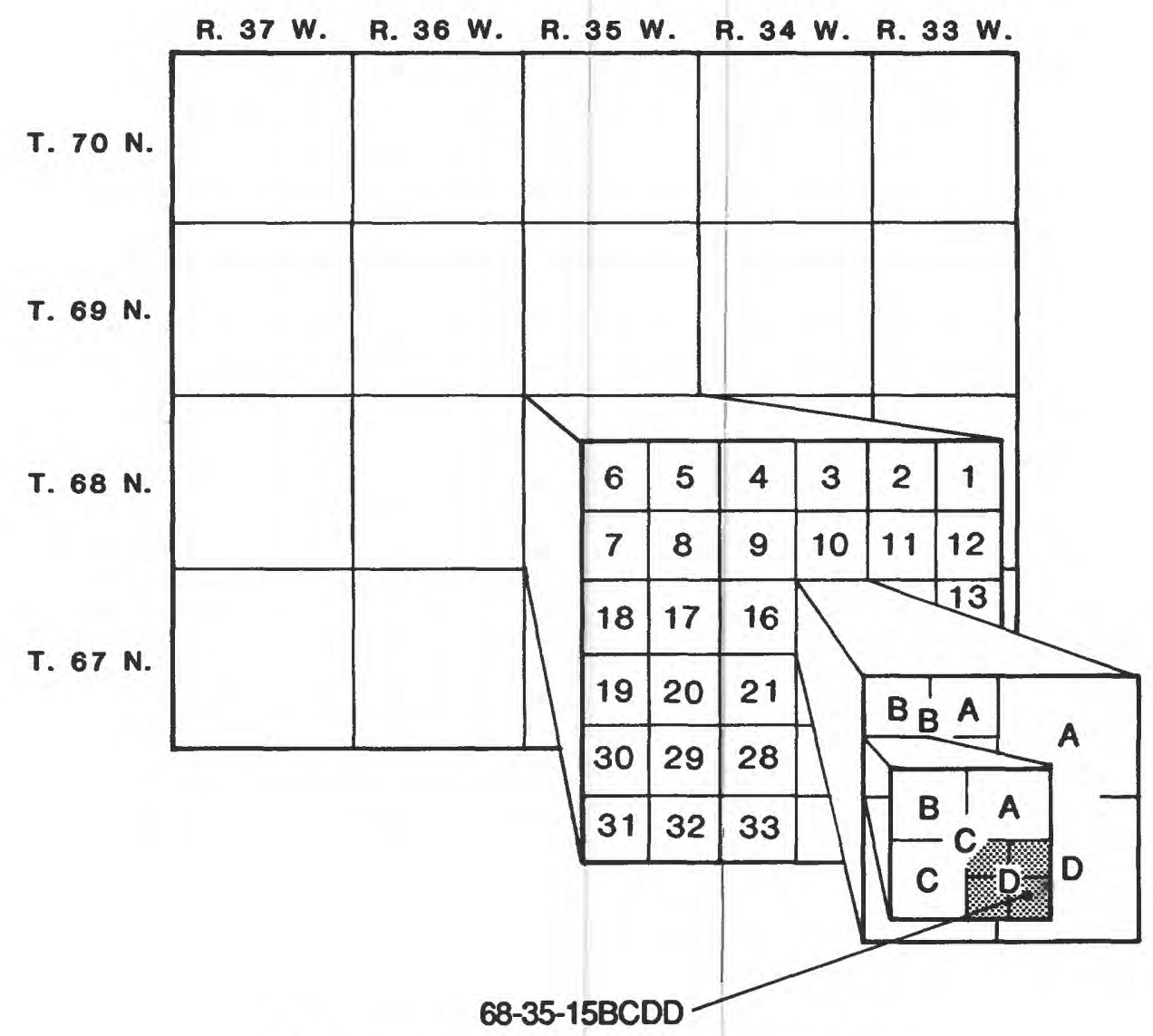

Figure 5. Well-location numbering system.

The occurrence of agricultural chemicals in Iowa's ground water is of concern not only because of acute health effects but also because of the potential hazard to health from long-term exposure to small concentrations. Large nitrate concentrations can cause methemoglobinemia (blue-baby syndrome) in infants, which may result in death. Long-term exposure to small concentrations of nitrate has been linked to birth defects, gastric cancer, and nervous-system impairment (Fraser and Chilvers, 1981; Dorsch and others, 1984; Forman and others, 1985). Much of the evidence for these additional adverse effects of nitrate is not established well yet.

The potential adverse health effects of pesticides are more difficult to assess as fewer studies have been done, particularly on the newer compounds. The U.S. Environmental Protection Agency is formulating approaches for dealing with pesticides in drinking water and has issued a proposed strategy (U.S. Environmental Protection Agency, written commun., 1989). This strategy has suggested the use of MCL regulations. However, at the present time
(1989), few MCLs have been set for pesticides (table 3). For many of the compounds, interim regulations will be based on standard risk-assessment procedures. For noncarcinogenic chemicals, health advisories will be established on a No Observable Effect Level (NOEL) basis. For carcinogenic chemicals, risk-assessment concentrations will be established that correspond to a carcinogenic risk of one-in-a-million. Some of the proposed health advisories and risk-assessment concentrations for pesticides commonly detected in drinking water in lowa are listed in table 4 at the back of this report.

Private wells in southwest lowa have larger nitrate concentrations than private wells in other parts of the State, based on summary data supplied by the University of lowa Hygienic Laboratory (University of lowa Hygienic Laboratory, written commun., 1988). In this report, nitrate refers to nitrate concentrations as nitrogen. The data set consists of private water-well analyses that were evaluated between 1981 and 1986. Well location is limited to a 


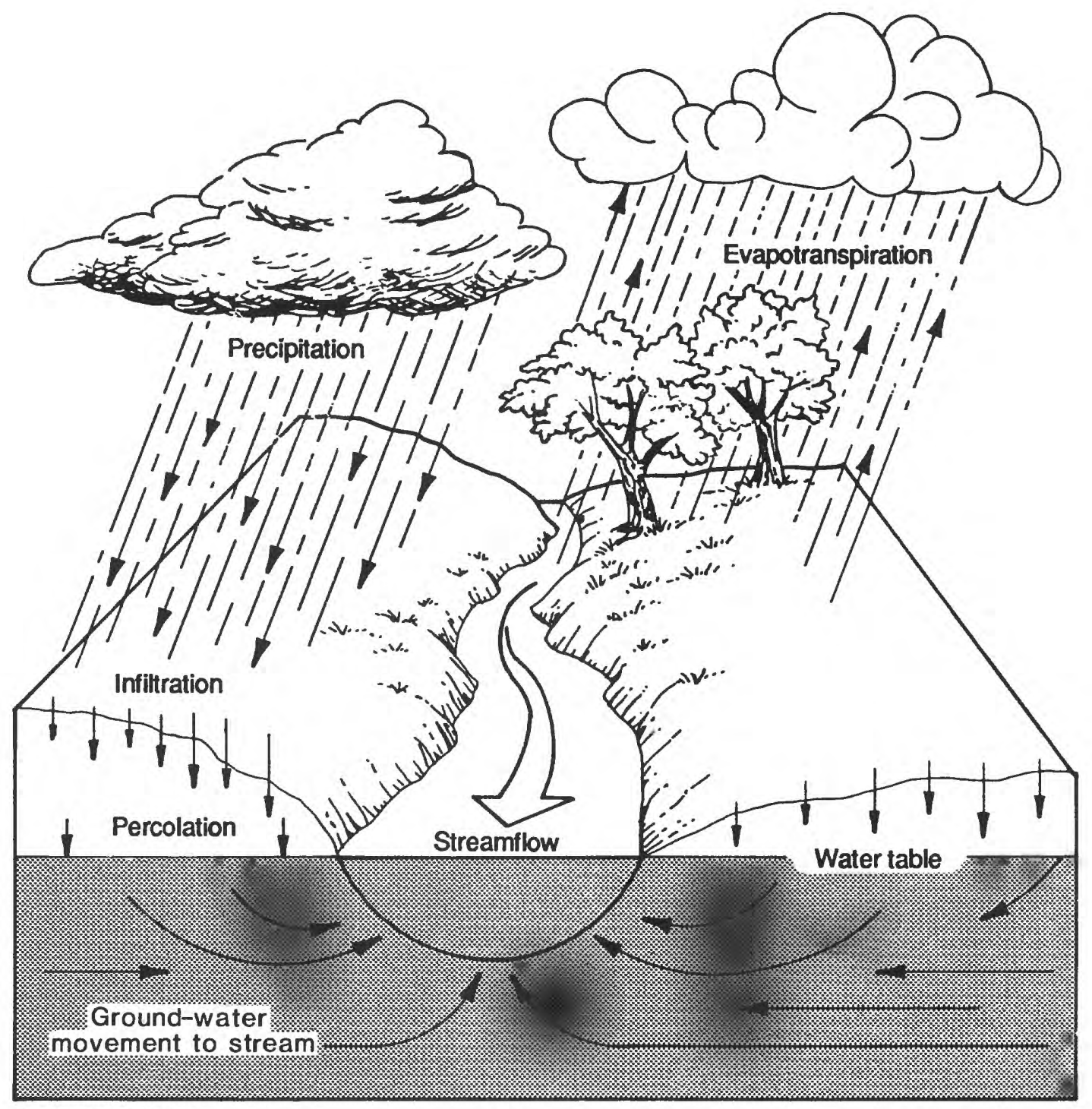

NOT TO SCALE

Figure 6. Hydrologic cycle.

mailing address and only occasionally is well depth reported by the individual submitting the sample. Thus, it is difficult to correlate these private analyses to aquifers. Private-well samples are voluntarily submitted and are usually submitted for a new well or when a known or suspected water-quality problem occurs. Private-well construction and maintenance are more variable than for municipal wells; thus, some of the analyses may reflect individual well problems. However, the large sample size of 3,437 wells generally compensates for any biases, and the data are believed to be a reasonable representation of overall nitrate concentration. The number and percentage of water samples containing nitrate concentrations of more than $10 \mathrm{mg} / \mathrm{L}$ (milligrams per liter) in each county from 1981 to 1986 are listed in table 5 at the back of this report.

The larger nitrate concentrations can be explained, in part, by reference to well depth in the area. It has been documented in Iowa that shallow wells, less than $100 \mathrm{ft}$ deep, are especially susceptible to contamination from agricultural chemicals and other surface-derived contaminants (Hallberg and Hoyer, 1982; Hallberg and others, 1983; Libra and others, 1984; Bruner and Hallberg, 1987). In southwest Iowa, few deep aquifers are available, and the 
water quality in most of these deeper aquifers often is unacceptable because of large dissolved-solids concentrations. The use of shallow sources for private drinking-water supplies also is widespread. The reliance on shallow drinking-water supplies for private wells in southwest Iowa is the reason for the generally larger nitrate concentrations as compared to the remainder of the State and may account for the larger percentage of wells with constituents exceeding the MCL.

\section{Acknowledgments}

The authors acknowledge and thank those people who aided in the collection of data and provided technical support during the study. Drilling contractors provided information from their files and their personal observations. Information on municipal supplies and water use was provided by the many local water superintendents. Residents in the area cooperated in supplying information about their wells.

\section{AVAILABILITY AND QUALITY OF GROUND WATER}

The main sources of ground water in southwest Iowa are surficial deposits of Quaternary age and the Dakota Formation of Cretaceous age. The surficial deposits are composed of unconsolidated materials and can be divided into two general types--alluvium and glacial drift. The Dakota Formation is the uppermost bedrock in parts of the study area. Rocks of Pennsylvanian age, which underlie the entire area, form a regional confining unit. Although water may be available from some rocks of Pennsylvanian age, both quantity and quality generally are unacceptable for most uses. A diagrammatic east-west section illustrating the principal hydrogeologic units is shown in figure 7, and table 6 at the back of this report lists the generalized stratigraphy in southwest Iowa.

\section{Alluvial Aquifers}

Alluvium is water-deposited material commonly found in flood plains along streams and rivers and is comprised of permeable sand and gravel interbedded with less-permeable clay and silt. The entire sequence of permeable and less-permeable materials usually is considered as an aquifer because of the degree of hydraulic connection between permeable zones.

Alluvial flood plains are present along the major streams in southwest Iowa. These flood plains are the broad, flat areas adjacent to the river, characterized by low relief and poor drainage. Terraces are remnants of former alluvial plains that have been eroded and are present along the valley margins of many streams. Terraces within the study area typically are considered part of the alluvial aquifer with which they are associated. At some locations, the river channels may be in direct contact with the sand and gravel, but in most areas the bottom of the river is within the finer grained alluvium. Soils in the alluvial valley commonly are silt loams or silty-clay loams that are developed on silty alluvium.

Recharge to alluvial aquifers normally occurs by infiltration of precipitation through the soil. The thick layer of fine-grained alluvial sediment that overlies the sand and gravel may prevent rapid infiltration and cause the aquifer to be semiconfined. Recharge and discharge relations in an alluvial aquifer also may be complicated by the presence of other aquifers that underlie or are adjacent to the alluvium. There are several areas in southwest Iowa where the Dakota aquifer underlies the alluvium. These aquifers may recharge the alluvium, or they may be recharged by the alluvium. Recharge to the aquifer, although slow, also occurs from water movement through the loess, along the loess-glacial till interface, or through glacial till. A description of the hydraulic relations among these aquifers is beyond the scope of this report.

Alluvial aquifers typically discharge to streams. Base flow is the term used to describe the ground water that discharges to a stream. Occasionally, during rainfall, stream levels will rise rapidly, causing the level of the stream to be higher than the surrounding water table. Water then flows from the stream into the aquifer. The quantity of water transferred between the stream and the aquifer depends on the hydraulic conductivity of the streambed, the water-table gradient, the permeability or hydraulic conductivity of the aquifer materials, and the amount of time the surface water is higher than the ground-water level. As the stream level decreases, the gradient reverses, and ground 


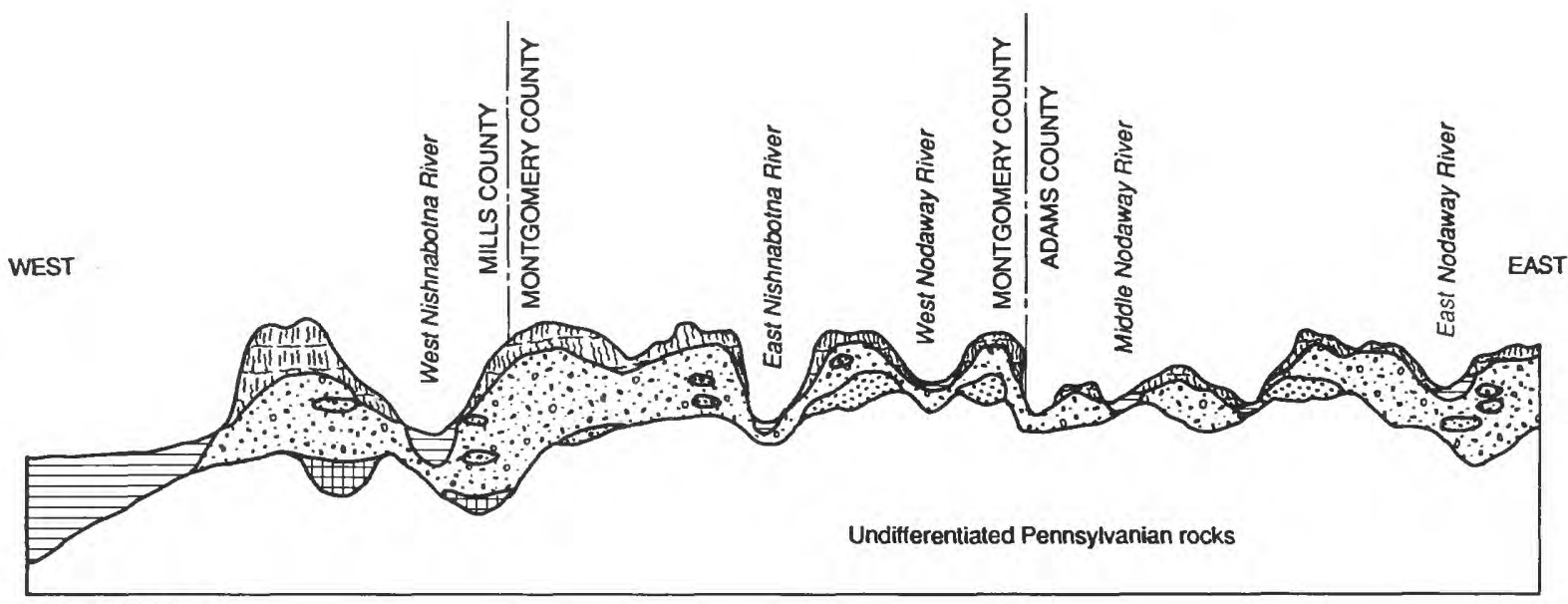

NOT TO SCALE

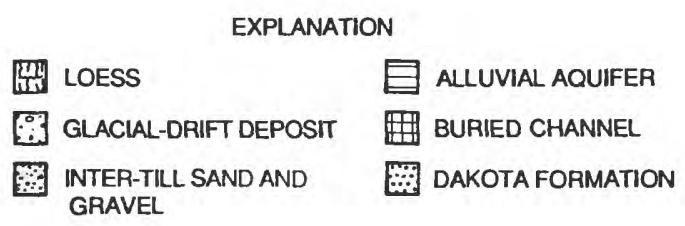

Figure 7. East-west hydrogeologic section across study area.

water discharges to the stream. This temporary storage of water in the aquifer is termed bank storage. If the aquifer consists of fine-grained material, bank-storage capacity may be less than if the aquifer consists of sand and gravel.

Water levels in an alluvial aquifer change throughout the year and usually are highest in late spring and fall. Water levels usually decline in summer because of increased evapotranspiration. Research on other alluvial aquifers in Iowa (Thompson, 1986, 1987) indicates that water levels tend to respond rapidly to precipitation; however, the thick cover of fine-grained sediment present in the alluvial aquifers of southwest Iowa may slow this response. Water levels measured in observation wells during this study are listed in table 7 at the back of this report.

Water levels also are affected by withdrawals from wells. When a well is pumped, water can be withdrawn from storage over a large area, and water levels decline (fig. 8). Prolonged pumping at high rates may eventually lower water levels below that of the stream, causing movement of water from the stream into the aquifer. The rate and area of water-level decline due to pumping depends on the aquifer boundaries, the hydraulic conductivity of the streambed, and the hydrogeologic properties of the aquifer.

The productivity of an aquifer is based, in part, on the thickness of the producing section. Areas of thicker sand and gravel generally will have larger yields. Additionally, areas where two aquifers are hydraulically connected, such as alluvium overlying the Dakota aquifer, may have larger yields. Specific-capacity data, a measure of aquifer yield, were gathered from historical records. From these data, and using an estimate for specific yield, transmissivities were calculated (Walton, 1960). The numbers presented in this report are a general guide to the availability of water because in alluvial systems the geology of the aquifer is highly variable and difficult to characterize. If large yields are needed, the aquifer needs to be evaluated by test 
drilling and pumping to determine the specific aquifer characteristics at a particular site.

Major alluvial aquifers occur along the East and West Nishnabotna Rivers and the Nodaway River. Minor aquifers occur along the Tarkio and One Hundred and Two Rivers. Two previous studies have been done on the alluvial aquifers in southwest Iowa, both of which focused on the Nishnabotna alluvial aquifer (Knochenmus, 1962; Stone, 1971).

\section{Nishnabotna Alluvial Aquifer}

The Nishnabotna alluvial valley is divided into two main branches along the West and East Nishnabotna Rivers (fig. 9). Both branches begin north of the study area in west-central lowa. The West Nishnabotna River enters the study area near Avoca in Pottawattamie County, and the East Nishnabotna River enters near Lorah in Cass County. The branches join southwest of Riverton in Fremont County. At the junction, the West Nishnabotna has a drainage area of 1,650 $\mathrm{mi}^{2}$, and the East Nishnabotna has a drainage area of $1,150 \mathrm{mi}^{2}$. The valley merges with that of the Missouri River valley south of Hamburg. The total drainage area is $2,820 \mathrm{mi}^{2}$ where the Nishnabotna River leaves the State.

Both the West and East Nishnabotna valleys are broad with low relief. Low terraces form part of the aquifer. The West Nishnabotna valley averages $2 \mathrm{mi}$ in width; average width of the East Nishnabotna valley is $1.5 \mathrm{mi}$. The West
Nishnabotna valley narrows to less than $1 \mathrm{mi}$ from Carson to south of Macedonia. The same valley narrowing is present in the East Nishnabotna from just north of Stennett to Red Oak. In both cases, the widths of the valleys are constrained by the presence of Pennsylvanian bedrock at shallow depths. Topographic relief is considerable; the valley floor averages about 150 $\mathrm{ft}$ below the uplands.

Much of the Nishnabotna alluvial aquifer is comprised of thick fine-grained alluvial deposits. Data from 94 test holes indicate the fine-grained deposits range from 2 to $43 \mathrm{ft}$ thick and average $21 \mathrm{ft}$ thick. The range and average of the fine-grained deposits for the two aquifer branches are similar. The underlying sand and gravel ranges from 3 to $45 \mathrm{ft}$ thick and averages $17 \mathrm{ft}$. The range of thickness of the sand and gravel for the two aquifer branches is similar, but the West Nishnabotna branch has a slightly greater average thickness, although the differences are not statistically significant. There is no systematic change in thickness along the valley in either the fine-grained increment or the sand and gravel. There is no apparent correlation between the thickness of the two units.

The Nishnabotna alluvial aquifer along the West Nishnabotna River is underlain by glacial drift, except for the area around Macedonia where the aquifer is underlain by Pennsylvanian rocks. The northern part of the Nishnabotna alluvial aquifer along the East Nishnabotna

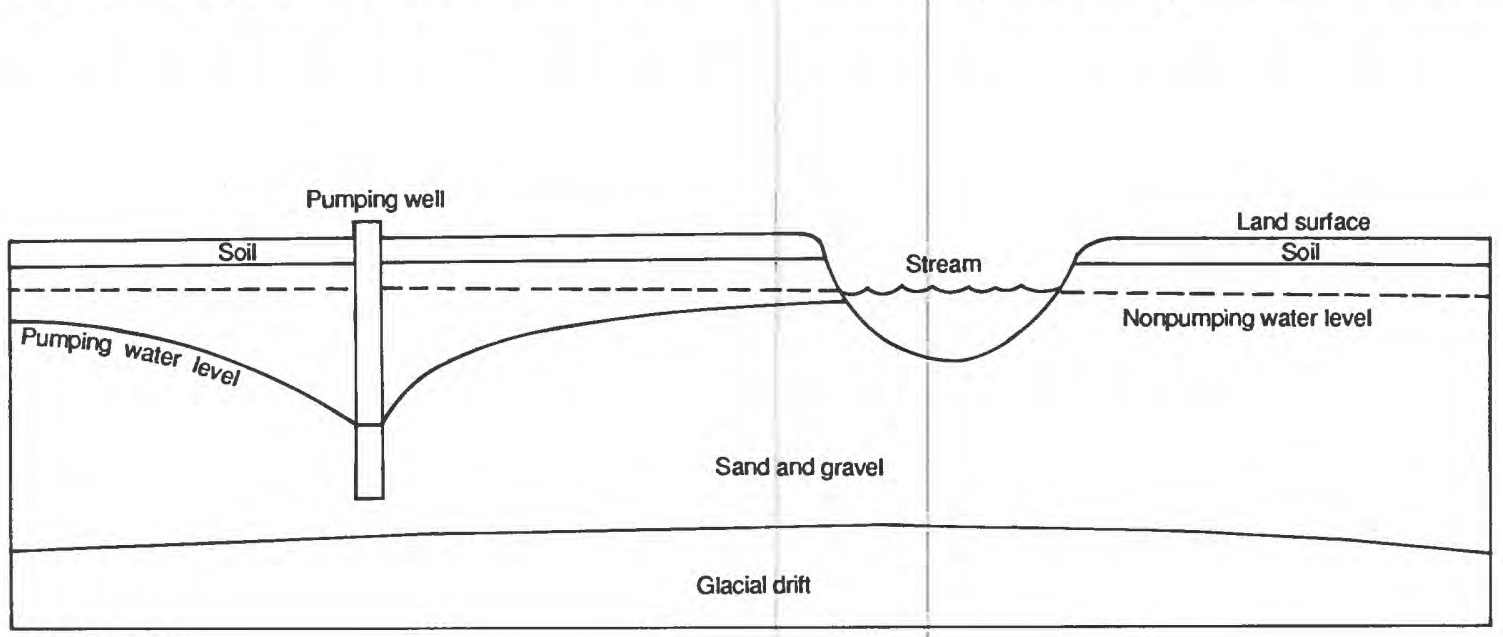

NOT TO SCALE

Figure 8. Relation between nonpumping and pumping water levels. 

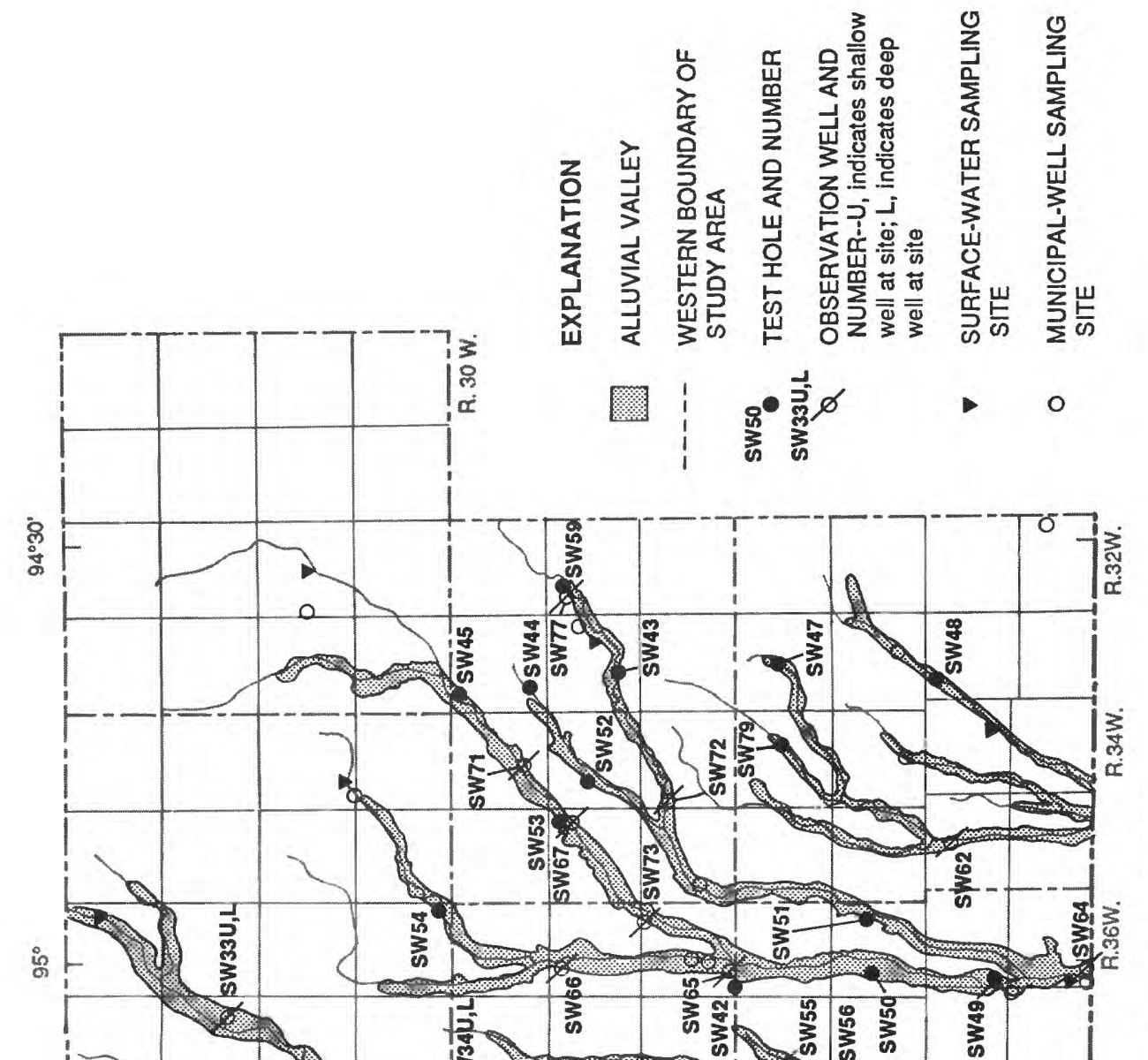

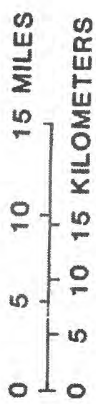

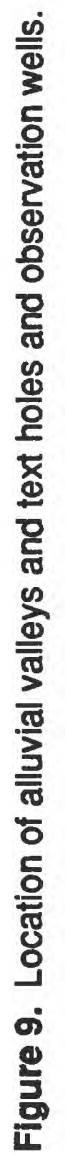


River in Cass and Montgomery Counties is mostly underlain by Pennsylvanian and Cretaceous rocks. The southern part of the aquifer in Page and Fremont Counties is underlain by glacial drift.

Aquifer hydraulic properties were estimated from specific-capacity data that were available for a few municipal wells. Assuming a storage coefficient of 0.01 , transmissivities in the Nishnabotna alluvial aquifer along the West Nishnabotna River range from approximately 1,000 to $4,300 \mathrm{ft}^{2} / \mathrm{d}$. Along the East Nishnabotna River, specific-capacity data were available only for the southern part of the Nishnabotna alluvial aquifer at Shenandoah and Farragut. Again using an estimated storage coefficient of 0.01 , transmissivities ranged from 1,700 to $8,000 \mathrm{ft}^{2} / \mathrm{d}$. Well yields of as much as $2,000 \mathrm{gal} / \mathrm{min}$ have been reported, but most wells are pumped at maximum rates of 100 to $250 \mathrm{gal} / \mathrm{min}$.

Water levels were measured in most observation wells from July 1986 to June 1988 (table 7). Frequent measurements were made in two alluvial wells, SW34L and SW16L (fig. 9). In general, water levels were deeper beneath terraces than beneath the flood plain. Water levels in terrace wells (SW16U, SW33U, SW38U) ranged from 10.15 to $20.30 \mathrm{ft}$ below land surface. Water levels in three wells located on the flood plain (SW34U, SW35U, SW36U) ranged from 2.06 to $12.58 \mathrm{ft}$ below land surface. The maximum observed water-level change in any well was $10.46 \mathrm{ft}$ in well SW36U. Water levels in the wells rise in response to increased precipitation and discharge in the adjoining rivers as shown in figure 10 .

When available, water levels from wells completed in the upper and lower parts of the alluvium were compared to evaluate vertical gradients. At three of five sites measured, vertical gradients were usually downward. Reversals of gradient direction did occur at some sites, but could not be related to any specific cause. The other two sites showed predominately upward gradients, with well SW36L (table 7) indicating a strong upward gradient on August 6, 1986. It is unknown whether this was caused by interconnection with other aquifers. The deep well at SW36 was completed in a different lithologic unit than the shallow well.
More water-quality data are available for the Nishnabotna alluvial aquifer than for other aquifers in southwest Iowa. Water samples were analyzed for major ions, trace elements, radionuclides, and pesticides from 10 municipal wells and 2 observation wells in the Nishnabotna alluvial aquifer along the West Nishnabotna River and 6 municipal wells and 5 observation wells in the Nishnabotna alluvial aquifer along the East Nishnabotna River (tables 8 through 10 at the back of this report). Historical water analyses (1950-86) also were examined to determine changes with time and to provide a larger data base. The number of analyses, the range of concentrations, and the mean concentration for water-quality properties and constituents in samples from the Nishnabotna alluvial aquifer are shown in table 11 at the back of this report. Mean concentrations were calculated with "less than" values set to zero. The mean concentrations of selected constituents are plotted in figure 11.

The water in both branches of the aquifer is classified as a calcium bicarbonate type. Water from the observation wells had sulfate concentrations that were less than those from the municipal wells. This difference in concentration may be caused by municipal pumping that induces recharge from other aquifers with larger sulfate concentrations. Iron concentrations were large and were often larger than the secondary regulation for iron (table 3 ).

Nitrate concentrations vary from well to well in the alluvium, making it difficult to characterize water quality. Three data sets from different sources were examined to evaluate nitrate concentrations. Historical data, 1950 to 1986 (table 11), indicated mean nitrate concentration of $2.0 \mathrm{mg} / \mathrm{L}$ for 216 analyses; the mean nitrate concentration for 216 samples collected during an Iowa Department of Natural Resources project in 1987 was $2.4 \mathrm{mg} / \mathrm{L}$ (Thompson and VanDorpe, 1988); and the mean nitrate concentration for 19 samples collected during this study, 1985 to 1987 , was $7.83 \mathrm{mg} / \mathrm{L}$ (table 8).

Differences in the data sets reflect the variability in nitrate concentrations due to well location, climatic patterns, sampling frequency, and time of year. Concentrations of nitrate were less than concentrations in samples from in the 

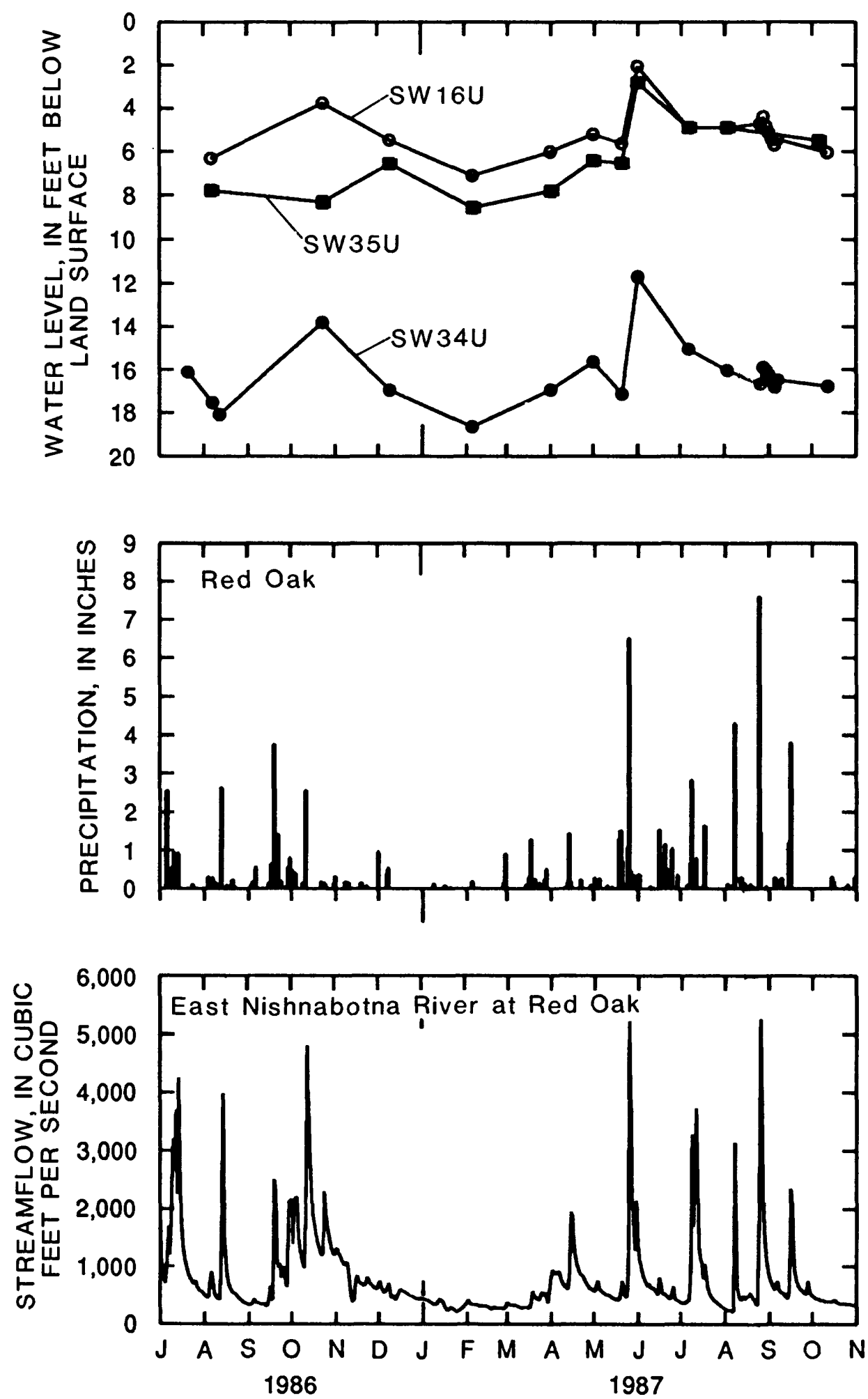

Figure 10. Water levels in selected alluvial-aquiter wells, precipitation at Red Oak, and streamflow in the East Nishnabotna River at Red Oak. 


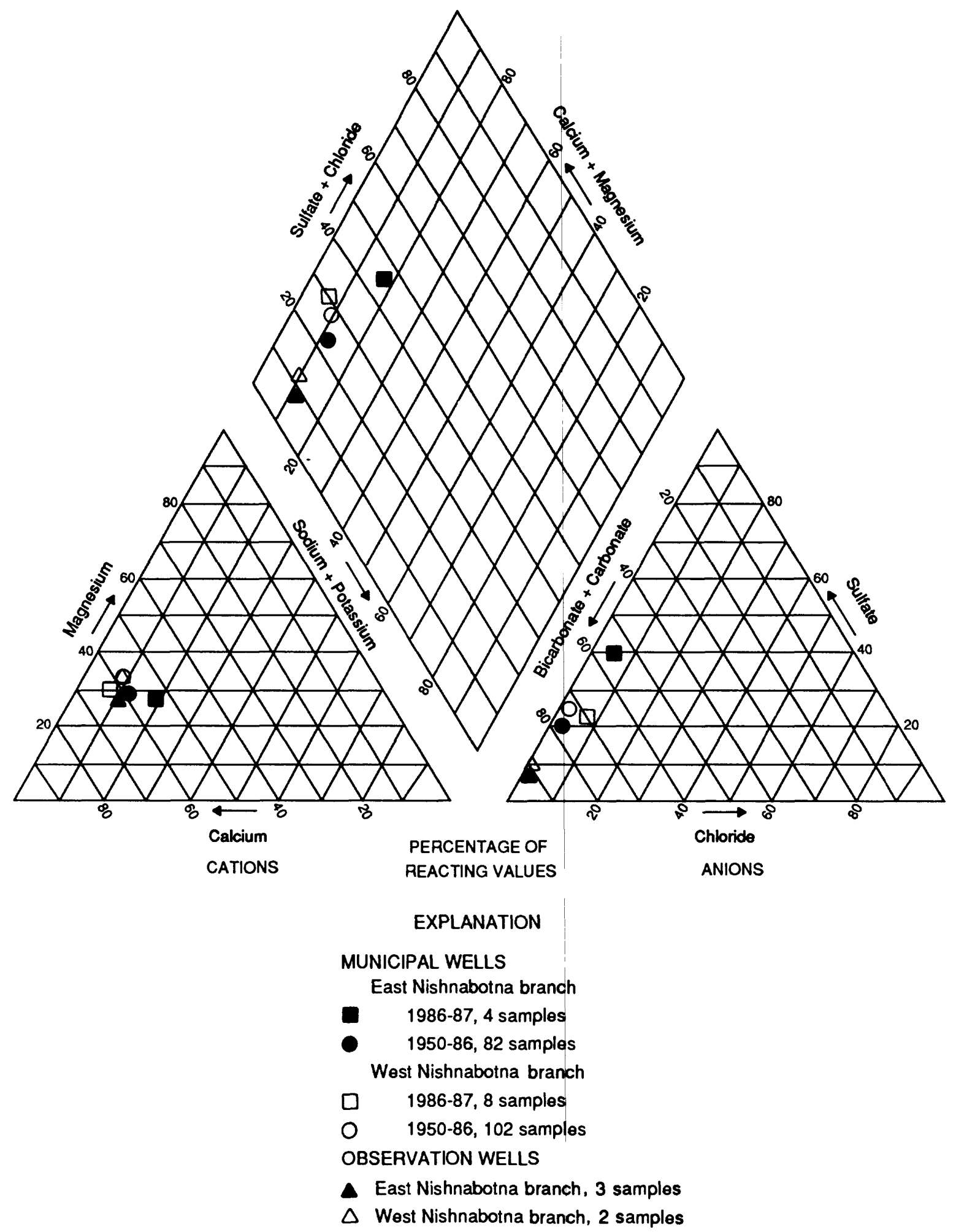

Figure 11. Mean water quality in the Nishnabotna alluvial aquifer. 
alluvial aquifers of the Ocheyedan-Little Sioux and Rock Rivers in northwest lowa (Thompson 1986, 1987). The mean nitrate concentrations were similar to those in the West Fork Des Moines River alluvial aquifer in north-central Iowa where denitrification has been postulated as a process for decreasing nitrate concentrations (Wehmeyer, 1988; Iowa Department of Natural Resources, Geological Survey Bureau, written commun., 1989). Denitrification or other possibilities for decreasing nitrate concentrations may be occurring in the fine-grained alluvium in the Nishnabotna alluvial aquifer but were not investigated during this study.

Large mean nitrate concentrations, greater than $3.0 \mathrm{mg} / \mathrm{L}$, appear to correlate with well position within the valley. Many of the wells with large mean nitrate concentrations are located near the valley edge. It has been hypothesized (Thompson and VanDorpe, 1988) that the alluvial aquifer is being recharged by shallow ground-water flow from the uplands containing larger nitrate concentrations.

A comparison of nitrate concentrations with precipitation and discharge records using previously collected data (Thompson and VanDorpe, 1988) produced varied results. Nitrate concentrations appear to correlate with rainfall at 5 of 14 monitored sites, 9 municipal wells, and 5 observation wells. At the other sites there was no apparent response in nitrate concentrations to rainfall.

Mean nitrate concentrations from surface-water samples collected during this study from both branches of the Nishnabotna River were larger than $41 \mathrm{mg} / \mathrm{L}$ (table 8). This may indicate that upland shallow ground-water flow is discharged to the river by tributary streams. Additionally, larger nitrate concentrations could occur at or near the water table in the fine-grained alluvium and be discharged laterally to the river instead of infiltrating to greater depths within the alluvium.

Atrazine is the most frequently detected pesticide in southwest Iowa and is the most common pesticide detected in Iowa. This is attributed to its long history of continual, widespread usage and its solubility. Metolachlor was the only pesticide other than atrazine detected at more than one location in southwest
Iowa. The results of pesticide sampling of the Nishnabotna alluvial aquifer from all available data are summarized in table 12 at the back of this report. Table 12 includes 24 pesticide analyses from untreated municipal-well water samples and 17 analyses of treated municipal water samples collected by the U.S. Geological Survey between 1985 and 1987 (M.L. Clark, U.S. Geological Survey, oral commun., 1989); 6 samples collected from alluvial observation wells installed along the Nishnabotna River during this study (table 10); and analyses of 23 municipal-well samples and 33 observation-well samples available from a concurrent project (Thompson and VanDorpe, 1988). Concentrations of detected pesticides were less than proposed regulations (table 4) except for alachlor. All of the pesticide detections were from municipal wells. Local point-source contamination is possible; however, most of the well sites are upgradient from any known or suspected point sources of contamination. Municipal pumping may affect normal flow paths, drawing water from a larger contributing area. Surface water might also be a source of pesticides, but in general the wells are located away from the river and withdrawal rates are small enough to minimize any possible interaction.

Atrazine, cyanazine, alachlor, and metolachlor have been detected in surface-water samples from both the East and West Nishnabotna Rivers (table 10). Concentrations often are larger than those detected in ground water. Alachlor has exceeded the proposed regulations (table 4).

\section{Tarkio Alluvial Aquifer}

The Tarkio alluvial aquifer is present along three streams--the Tarkio River, West Tarkio Creek, and East Tarkio Creek (fig. 9). All three streams begin in Montgomery County. The Tarkio River at the Missouri border has a drainage area of $206 \mathrm{mi}^{2}$. Valley width varies from 0.25 to $1.25 \mathrm{mi}$ and averages slightly more than $0.5 \mathrm{mi}$. West Tarkio Creek at the Missouri border has a drainage area of $92.5 \mathrm{mi}^{2}$. Valley width ranges from 0.25 to $0.75 \mathrm{mi}$ and averages $0.5 \mathrm{mi}$. East Tarkio Creek joins the Tarkio River north of Coin where it has a drainage area of 58.2 $\mathrm{mi}^{2}$. Average valley width is $0.4 \mathrm{mi}$. 
The alluvial deposits along the main stem of the Tarkio River consist of a thin layer of sand and gravel, 4 to $9 \mathrm{ft}$ thick, below a thick layer of fine-grained alluvium, 40 to $58 \mathrm{ft}$ thick. No information is available on alluvial deposits along either East or West Tarkio Creeks. Because of the limited areal extent of all branches, only the main valley of the Tarkio River was investigated during this study. The only previous drilling information available is near the town of Coin (fig. 9), where the valley is underlain by glacial drift. Test holes at three other locations in Page County indicate that parts of the valley are underlain by Pennsylvanian shale.

Transmissivity was estimated from data collected at Blanchard (fig. 9). Assuming a storage coefficient of 0.01 , transmissivities range from 210 to $250 \mathrm{ft}^{2} / \mathrm{d}$. Yields from the Blanchard municipal wells are 20 to $30 \mathrm{gal} / \mathrm{min}$.

Water levels were measured in observation wells SW55, SW56, and SW57 (fig. 9) in October and November 1987 and ranged from 9.53 to $27.65 \mathrm{ft}$ below ground level (table 7). Water levels generally decreased during the months measured, corresponding to a decrease in the discharge of the Tarkio River. The maximum water-level change in any well was $1.05 \mathrm{ft}$.

The water from observation wells SW55 and SW56 (fig. 9), located north of the town of Blanchard, can be classified as a calcium bicarbonate type (fig. 12). There are noticeable differences in water from the two observation wells. Well SW56 has an extremely small concentration of sulfate, $9 \mathrm{mg} / \mathrm{L}$, but a larger sodium concentration, $41 \mathrm{mg} / \mathrm{L}$, than detected in other alluvial-aquifer samples (table 8). Well SW55 has more typical concentrations of the two ions--sulfate, $52 \mathrm{mg} / \mathrm{L}$, and sodium, $14 \mathrm{mg} / \mathrm{L}$. Both observation wells have less sulfate and chloride than the other samples from municipal wells (table 11), which may be related to the effects of ground-water withdrawal. Nitrate concentrations are small, less than $0.1 \mathrm{mg} / \mathrm{L}$ for the observation wells, and ranging from 0.2 to 1.4 $\mathrm{mg} / \mathrm{L}$ in the other samples. One surface-water sample from the Tarkio River near Blanchard had a nitrate concentration of $4.2 \mathrm{mg} / \mathrm{L}$ during October 1987 (table 8). Water from observation wells SW55 and SW56 does indicate some chemical anomalies. Ammonia as nitrogen concentrations are large, 4.6 and $9.5 \mathrm{mg} / \mathrm{L}$. There also is a larger than usual chemical oxygen demand, indicating a reducing environment may exist.

Observation wells SW55 and SW56 and the Tarkio River were sampled for pesticides in October 1987; none were detected (table 10). The well at Blanchard, the only municipal well in the Tarkio alluvial aquifer, did have a detection of atrazine, $0.25 \mu \mathrm{g} / \mathrm{L}$ (microgram per liter), in a sample of treated water during November 1986 (table 13 at the back of this report).

\section{Nodaway Alluvial Aquifer}

The Nodaway River is divided into three main streams--the West, Middle, and East Nodaway Rivers (fig. 9). The Middle Nodaway River begins in Adair County and joins the West Nodaway River just south of Villisca and has a drainage area of $341 \mathrm{mi}^{2}$. The East Nodaway River begins in Union County, south-central Iowa, and enters the study area in Adams County. A main tributary, Kemp Creek, flows into the East Nodaway River in Adams County northeast of Nodaway. The drainage area of the East Nodaway River at the junction with the West Nodaway River north of Braddyville is $334 \mathrm{mi}^{2}$. The Nodaway River leaves the State at Braddyville where it has a drainage area of 1,180 $\mathrm{mi}^{2}$.

The alluvial valleys of the three main branches of the Nodaway River are moderately broad, ranging from 0.2 to $2 \mathrm{mi}$ wide. The East Nodaway River valley has the smallest average width, $0.8 \mathrm{mi}$, and the Middle Nodaway River valley the largest, $1.2 \mathrm{mi}$. The valleys are constricted by bedrock outcrops at various points along their course. Low terraces are present along the valley margins and form part of the alluvial aquifer.

The sequence of alluvial sediments is similar to the other alluvial aquifers in southwest Iowa. On the basis of logs from 41 test holes, the fine-grained alluvium, ranging from 10 to $37 \mathrm{ft}$ thick, overlies sand and gravel ranging from 0 to $30 \mathrm{ft}$ thick. The fine-grained alluvium averages about $20 \mathrm{ft}$ thick, and the sand and gravel averages about $10 \mathrm{ft}$ thick. Ranges and averages are similar along all Nodaway River branches, except for the East Nodaway, which has a thicker layer of fine-grained alluvium. Most of the 
alluvium is underlain by shale or limestone of Pennsylvanian age. The upper reaches of the East Nodaway River and Kemp Creek in Adams County are underlain by glacial drift.

The yield of the Nodaway alluvial aquifer is small because of the thin sand and gravel. Using an estimated storage coefficient of 0.01 , transmissivities range from 90 to $570 \mathrm{ft}^{2} / \mathrm{d}$. Well yields range from 12 to $100 \mathrm{gal} / \mathrm{min}$ among the municipal wells that use the Nodaway alluvial aquifer. No irrigation permits have been issued for the Nodaway alluvial aquifer.

Water levels were measured in eight wells from September to November 1987 (table 7). Water levels varied from 1.00 to $21.53 \mathrm{ft}$ below ground level. Water levels gradually decreased during the measurement period, as did discharge in the streams. The maximum water-level change observed in any well was $2.36 \mathrm{ft}$. All the sites are on the flood plain. However, the upper reaches of the river are more deeply incised, creating steeper water-table gradients and accounting for the large differences in water levels.

Water from the Nodaway alluvial aquifer is a calcium bicarbonate type as shown in figure 12 . Historical data from 1950 to 1986 for the principal ions in samples from the Nodaway alluvial aquifer are summarized in table 11. A slight difference in anion concentration in samples exists between the observation wells and the municipal wells. Samples from the municipal wells usually have larger sulfate concentrations than samples from the observation wells. Pumping may induce flow from the underlying Pennsylvanian rocks, which generally have large concentrations of sulfate. Iron concentrations (table 8) ranged from less than 20 to $26,000 \mu \mathrm{g} / \mathrm{L}$ and commonly exceeded the secondary regulation of $300 \mu \mathrm{g} / \mathrm{L}$ (table 3). Nitrate concentrations in the Nodaway alluvial aquifer generally are less than $1.0 \mathrm{mg} / \mathrm{L}$ (table 8). Surface water in the basin also has large concentrations of nitrate, ranging from 2.0 to $4.9 \mathrm{mg} / \mathrm{L}$ for samples collected during October 1987 (table 8).

Pesticides were detected at only one municipal well completed in the Nodaway alluvial aquifer (table 13). An atrazine concentration of $0.28 \mu \mathrm{g} / \mathrm{L}$ and a cyanazine concentration of $0.1 \mu \mathrm{g} / \mathrm{L}$ were detected in a sample from one well at Fontanelle during August 1986. During August 1987, only atrazine was detected at a concentration of $0.11 \mu \mathrm{g} / \mathrm{L}$. There were 21 pesticide analyses from untreated ground-water samples available from 11 municipal wells in 8 towns and 7 observation wells. An additional seven municipal treated-water samples were available. All pesticides detected were less than proposed regulations (table 4).

Five surface-water samples were collected from the Nodaway River system during October 1987 (table 10). Atrazine was detected at two sampling sites at concentrations of 0.10 and 0.18 $\mu \mathrm{g} / \mathrm{L}$. No pesticides were detected in March 1982 in a sample from Clarinda (fig. 9), which uses water from the Nodaway River. Atrazine, 0.20 $\mu \mathrm{g} / \mathrm{L}$, was detected in a treated-water sample from Clarinda during November 1986. The Page Rural Water District, which also uses water from the Nodaway River, had detections of atrazine, $0.65 \mu \mathrm{g} / \mathrm{L}$, and cyanazine, $0.31 \mu \mathrm{g} / \mathrm{L}$, in a sample collected during July 1987.

\section{One Hundred and Two Alluvial Aquifer}

The One Hundred and Two River is divided into three main streams--the East Fork, Middle Fork, and West Fork (fig. 9). Most of the river is within Taylor County. The West Fork One Hundred and Two River, including the West and Middle Fork tributaries, has a drainage area of $212 \mathrm{mi}^{2}$ at the Missouri border. Drainage areas of the Middle and East Fork One Hundred and Two Rivers at the border are 62.1 and $111 \mathrm{mi}^{2}$, respectively. The valleys generally are narrow, ranging from 0.2 to $1 \mathrm{mi}$ in width and averaging about $0.5 \mathrm{mi}$.

Information on the One Hundred and Two River alluvial deposits is limited. Data from seven boreholes were available and indicate 1 to $15 \mathrm{ft}$ of sand and gravel underlying 6 to $38 \mathrm{ft}$ of fine-grained alluvium. At three of the four test holes or observation wells drilled for this study, the aquifer is underlain by glacial drift. One site, well SW62 (fig. 9), in western Taylor County near New Market, is underlain by shale of Pennsylvanian age.

Observation well SW62 (fig. 9) was installed in the One Hundred and Two alluvial aquifer during this study. Water levels in that well decreased from 21.70 to $23.09 \mathrm{ft}$ below ground 
level during measurements made from September to November 1987 (table 7). The gradual decrease in water level corresponded to decreased precipitation and decreased discharge in the One Hundred and Two River during the same period. No data are available on specific capacity. Two towns, Conway and Gravity, currently use water from the One Hundred and Two alluvial aquifer, with well yields of 12 to 40 $\mathrm{gal} / \mathrm{min}$. The town of New Market previously used water from a well completed in the One Hundred and Two alluvial aquifer that had a yield of $50 \mathrm{gal} / \mathrm{min}$.

One sample of water for chemical analysis was collected from observation well SW62 (table 8). There were an additional 16 analyses available from municipal wells (table 11). The water can be classified as a calcium bicarbonate type (fig. 12). Nitrate concentrations are small, ranging from less than 0.10 to $0.40 \mathrm{mg} / \mathrm{L}$. A nitrate concentration of $1.0 \mathrm{mg} / \mathrm{L}$ was detected in a surface-water sample from the One Hundred and Two River near Bedford in October 1987. Iron concentrations (table 11) are large and are usually much larger than the secondary drinking-water regulation (table 3). No pesticides were detected in a sample from an observation well in October 1987 (table 10). Pesticide analyses were available for Conway and Gravity from samples of both treated and untreated water (table 13). Two pesticides, alachlor and atrazine, were detected at Conway; three pesticides, alachlor, metolachlor, and 2,4-D, were detected at Gravity. Concentrations of alachlor exceeded the proposed regulation (table 4). No pesticides were detected in a surface-water sample collected from the West Fork One Hundred and Two River during October 1987 (table 10).

\section{Glacial-Drift Aquifers}

Glacial drift, for the purposes of this report, includes all deposits that predominantly are glacial in origin or are the result of multiple periods of glaciation that occurred in the area. Loess and buried-channel deposits, although not strictly interpreted to be of glacial origin, have been included within the glacial-drift definition because of their stratigraphic association with deposits of glacial origin. The thickness of the glacial drift in southwest Iowa is about $200 \mathrm{ft}$ over upland areas of the bedrock surface and about $450 \mathrm{ft}$ over some parts of valleys eroded into the bedrock surface. The typical known range of thickness of the glacial drift in southwest Iowa counties is shown in table 14 at the back of this report.

Loess, a wind-deposited material, mantles the other glacial-drift deposits in most areas of Iowa. Loess predominantly consists of silt-sized particles but also can be partially comprised of clay and minor quantities of fine sand. Loess deposits in southwest Iowa generally are less than $30 \mathrm{ft}$ thick, except in the Western Loess Hills region (fig. 2) where the deposits generally are more than $50 \mathrm{ft}$ thick and have a recorded maximum thickness of $152 \mathrm{ft}$. The loess deposits thin and decrease in particle size with distance from the Missouri River valley.

The glacial drift beneath the loess is a mixture of sediment transported and deposited by glaciers or resulting from meltwater between or during glacial periods. These deposits generally are classified into one of two types--glacial till and stratified drift. Glacial-till deposits are most prevalent in the study area and consist of an unsorted mixture of sand, silt, clay, gravel, and boulders. The stratified drift usually shows the effect of water transport during and between glacial periods by the degree of particle-size sorting in sand and gravel deposits. The stratified-drift sand and gravel deposits are discontinuous, generally thin and lenticular, and may be beneath or within the glacial till.

The fine-grained matrix characteristic of the glacial-till deposits and the discontinuity of the stratified-drift deposits make the glacial drift an effective confining material. However, aquifers underlying glacial drift can be recharged by slow vertical leakage. Stratified glacial drift within and at the base of the glacial till includes pockets or lenses of sand or sand and gravel that are sources of water.

Glacial-drift aquifers are most likely to occur in four settings (fig. 7). These are: (1) loess, (2) sand and gravel within the glacial till, (3) sand and gravel deposits at the base of the glacial-drift materials, and (4) sand and gravel deposits in former stream channels eroded into the bedrock surface and subsequently buried by glacial drift. Many rural domestic and livestock water supplies and several municipal supplies are 


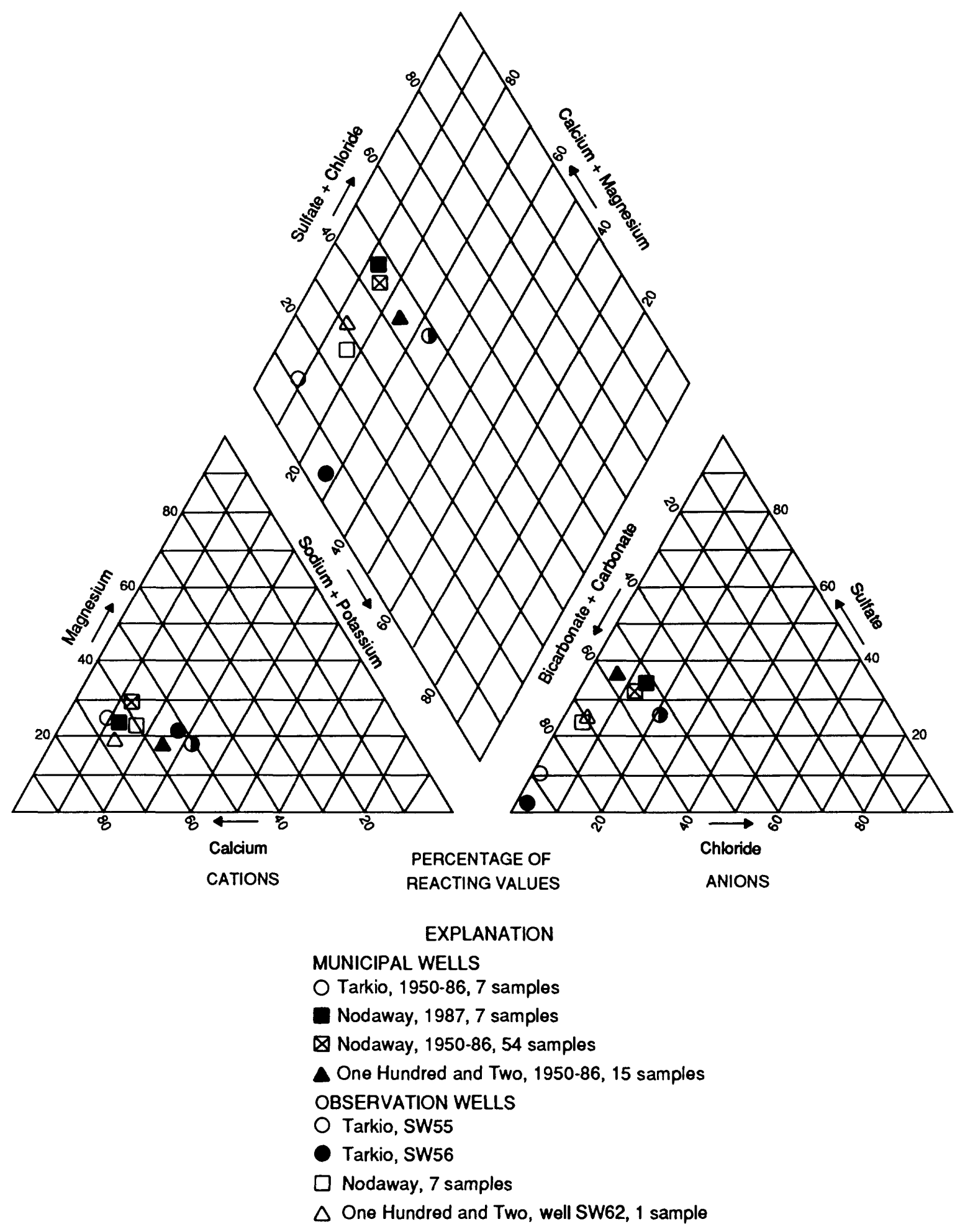

Figure 12. Mean water quality in the Tarkio, Nodaway, and One Hundred and Two alluvial aquifers. 
obtained from glacial-drift aquifers although, except for buried channels, these aquifers generally are not considered to be sources of large volumes of water.

\section{Loess Aquifer}

Loess usually is not considered to be an aquifer in most areas of Iowa because of low permeability. However, loess materials generally are more permeable than underlying glacial-till deposits and allow seepage of water to large-diameter wells at rates that may sustain small withdrawals. The loess is an important source of water for some southwest Iowa rural-domestic and livestock supplies because of its near-surface occurrence and the lack of other acceptable water sources. Most of the southeastern part of the study area has had to depend on these aquifers as a principal source of ground water because other sources of potable water are not economically available. Yields from wells completed in the loess usually produce less than $5 \mathrm{gal} / \mathrm{min}$ although 5- to $10-\mathrm{gal} / \mathrm{min}$ yields are not uncommon. Only a few well yields of more than $20 \mathrm{gal} / \mathrm{min}$ have been reported. No municipal wells are known that use these aquifers.

Water levels in wells in the loess usually represent the water-table surface. The water levels usually are not deep, often less than $20 \mathrm{ft}$. These shallow water levels are responsive to local precipitation, which is the source of recharge to these aquifers. When excess moisture is available, the aquifer will be recharged, and the water level will rise. During periods of drought, little moisture is available for recharge, and the water level will decline.

The most common type of well that is completed in the loess is a bored well less than $\mathbf{5 0}$ $\mathrm{ft}$ deep and usually from 12 to $48 \mathrm{in}$. in diameter. The large diameter provides additional area for seepage of water into the well and also increases the volume of water that is stored within the well bore. The use of multiple wells is a method of obtaining a larger quantity of water for a user. Several shallow wells can be located in an area without causing interference during pumping.

\section{Inter-till Sand and Gravel Aquifers}

The inter-till sand and gravel aquifers within the glacial drift are comprised of thin, lenticular, and discontinuous sand or sand and gravel pockets. The location, altitude of the top, and the thickness of the sand and gravel deposits that have been recorded on available geological logs are shown in figure 13. Control points on the map without altitude and thickness data indicate a well location at which no sand or gravel deposits were logged. In general, the thicknesses of sand and gravel deposits, where present, is less than $10 \mathrm{ft}$. Only a few logs indicate recorded thicknesses greater than $15 \mathrm{ft}$.

Many rural residents use these inter-till sand and gravel aquifers. Often the yields are small, requiring the use of large-diameter seepage wells. At some locations, larger yields can be obtained, and several municipalities use this type of aquifer, including College Springs, Cumberland, Minden, and Underwood. Their wells are completed at depths from 22 to $156 \mathrm{ft}$, and well yields vary from 10 to $120 \mathrm{gal} / \mathrm{min}$.

\section{Basal Sand and Gravel Aquifers}

The sand and gravel aquifers at the base of the glacial-drift materials are comprised of sand and gravel, intermixed with some silt, which were deposited on the bedrock surface. These deposits are discontinuous, generally on upland areas of the bedrock surface, and range from 1 to $39 \mathrm{ft}$ thick. These aquifers typically are thinner in southwest Iowa than in areas to the north and east of the study area where the sand and gravel deposits in some locations are more than $100 \mathrm{ft}$ thick. Most of the aquifer material is fine-to-coarse sand or sand and gravel. The altitude of the top and thickness of basal sand and gravel deposits are shown in figure 14. Control points on the map without altitude and thickness data indicate a well location at which no basal sand or gravel deposits were recorded.

It has been recognized by some geologists and drilling contractors (Darwin Evans, Brian Witzke, Greg Ludvigson, Iowa Department of Natural Resources, Geological Survey Bureau, and $\mathrm{D}$. Weilage, drilling contractor, oral commun., 1987) that there are two distinct types of "sand" present: (1) glacial-derived sand, which contains carbonate grains, and (2) "salt and pepper" sand, which contains volcanic-rock fragments and plagioclase feldspar (Witzke and Ludvigson, 1988). The "salt and pepper" sand may be equivalent to Miocene or Miocene and 

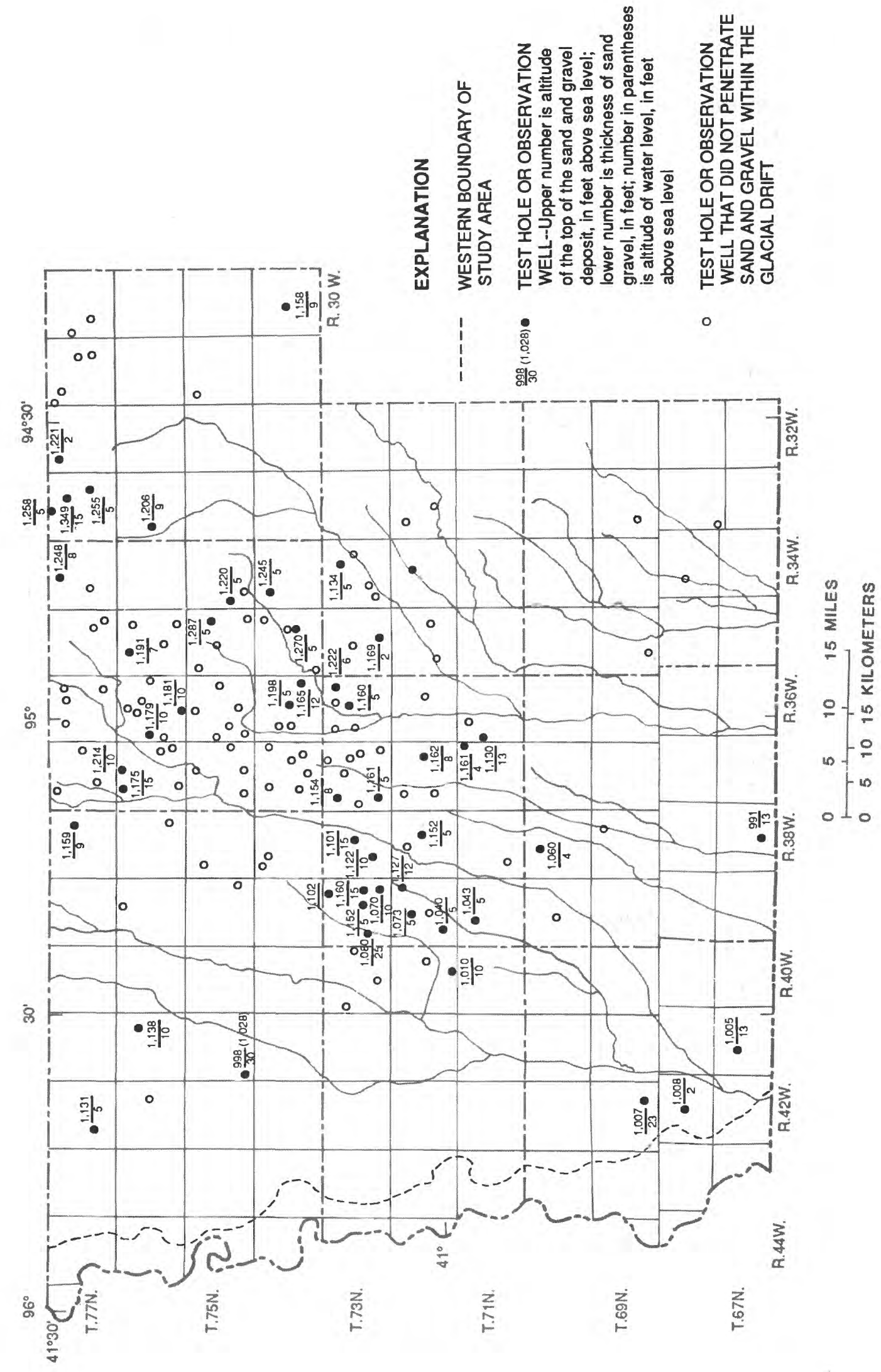

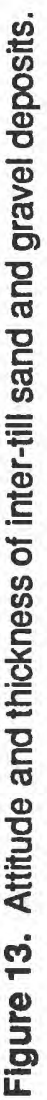


Pliocene strata in Nebraska. For purposes of this report, distinctions between these two units will not be considered because the distribution, physical geometry, and stratigraphic position of the "salt and pepper" sand are only now (1991) being evaluated and older well-log information has not been reevaluated.

The basal sand and gravel aquifers are important sources of water for rural-domestic and livestock supplies and for some municipal supplies. Emerson and Underwood (fig. 14) obtain their water supply from basal sand and gravel deposits. Several other towns have wells completed in these aquifers, but the wells are for standby or occasional use only and are not the main source of supply. Most rural wells in this type of aquifer are reported to yield $10 \mathrm{gal} / \mathrm{min}$ or less, but yields as large as $35 \mathrm{gal} / \mathrm{min}$ have been reported. About $98,000 \mathrm{gal} / \mathrm{d}$ are pumped from these deposits for municipal use. No attempt was made to calculate the potential yield of these aquifers because of the discontinuous nature of the materials and the small quantity of available information. Historical water levels range in altitude from more than $1,200 \mathrm{ft}$ in the northeast to less than $1,000 \mathrm{ft}$ in the west and southwest parts of the study area. Recharge to the aquifers is from leakage through the overlying glacial drift, and locally, some recharge may occur from the underlying Dakota aquifer where present.

\section{Buried-Channel Aquifers}

The bedrock surface in southwest Iowa (fig. 15) has been eroded to form uplands and valleys. In places the valleys of present-day streams are superimposed on the bedrock valleys, and exposures of the bedrock surface are present along the valley walls. In other areas, deposits of glacial drift have buried the bedrock valleys. Buried bedrock valleys that contain sand and gravel deposited by streams that flowed before, during, or between glacial advances are productive aquifers in many areas of Iowa and are called buried-channel aquifers.

Two bedrock valleys in southwest Iowa are known to contain sand and gravel deposits that form buried-channel aquifers. Data available for other parts of the study area where bedrock valleys are present indicate that some of these bedrock valleys are filled with fine-grained glacial drift and do not contain buried-channel aquifers. Several bedrock valleys are the upper part of bedrock valleys that contain sand and gravel deposits farther south in Missouri.

The quantity of aquifer material penetrated by test holes and observation wells in buried-channel areas is variable (fig. 16). The extent and thickness of the aquifer material cannot be predicted based on the limited information available in these areas. Additional exploration is needed to fully define the occurrence and hydraulic properties of these aquifers in southwest Iowa.

The Fremont channel (fig. 16) is the largest and beșt-known buried channel in southwest Iowa and crosses Pottawattamie, Mills, and Fremont Counties from north to south. It is part of a buried channel beginning in Minnesota north of northwest Iowa and continuing to the southeast through Fremont County into Missouri. The bedrock-contour map (fig. 15) also shows several large tributaries to the Fremont channel and several smaller channels paralleling the main channel.

The main Fremont channel is eroded into the bedrock nearly $200 \mathrm{ft}$ below the altitude of the adjacent bedrock uplands (fig. 15). Logs of wells drilled into the channel indicate that sand and gravel deposits in the channel range from 10 to about $300 \mathrm{ft}$ thick (fig. 16). The deposits generally are thickest in the deepest part of the channel. It is not known if all of the tributary bedrock channels contain sand and gravel deposits.

The potentiometric surface of the Fremont buried-channel aquifer ranges in altitude from $965 \mathrm{ft}$ northwest of Randolph in Fremont County to $1,164 \mathrm{ft}$ south of Hancock in Pottawattamie County. Average altitudes of water levels measured during this study in observation wells SW32, SW37, SW39U, and SW39L indicate that ground water is moving in the aquifer from north to south (table 7).

The sources of recharge to the Fremont buried-channel aquifer are inflow from the north and downward leakage through overlying glacial drift in areas where overlying materials have higher water levels. Some recharge-discharge relations may occur between the basal sand and gravel aquifers and the Fremont buried-channel aquifer. More observation wells would be needed 


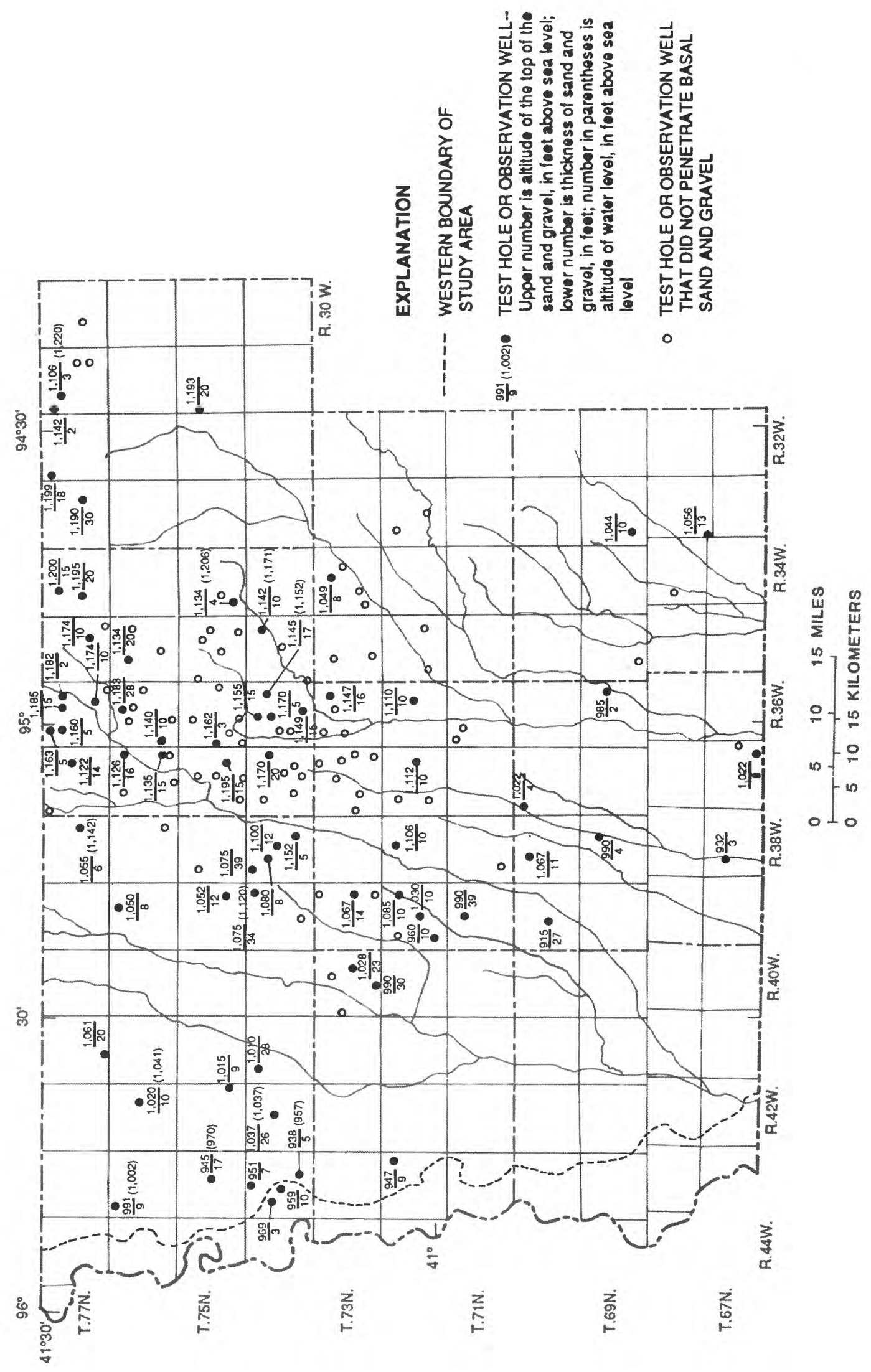

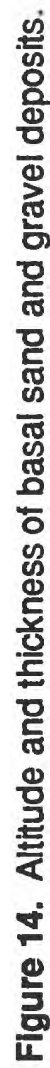



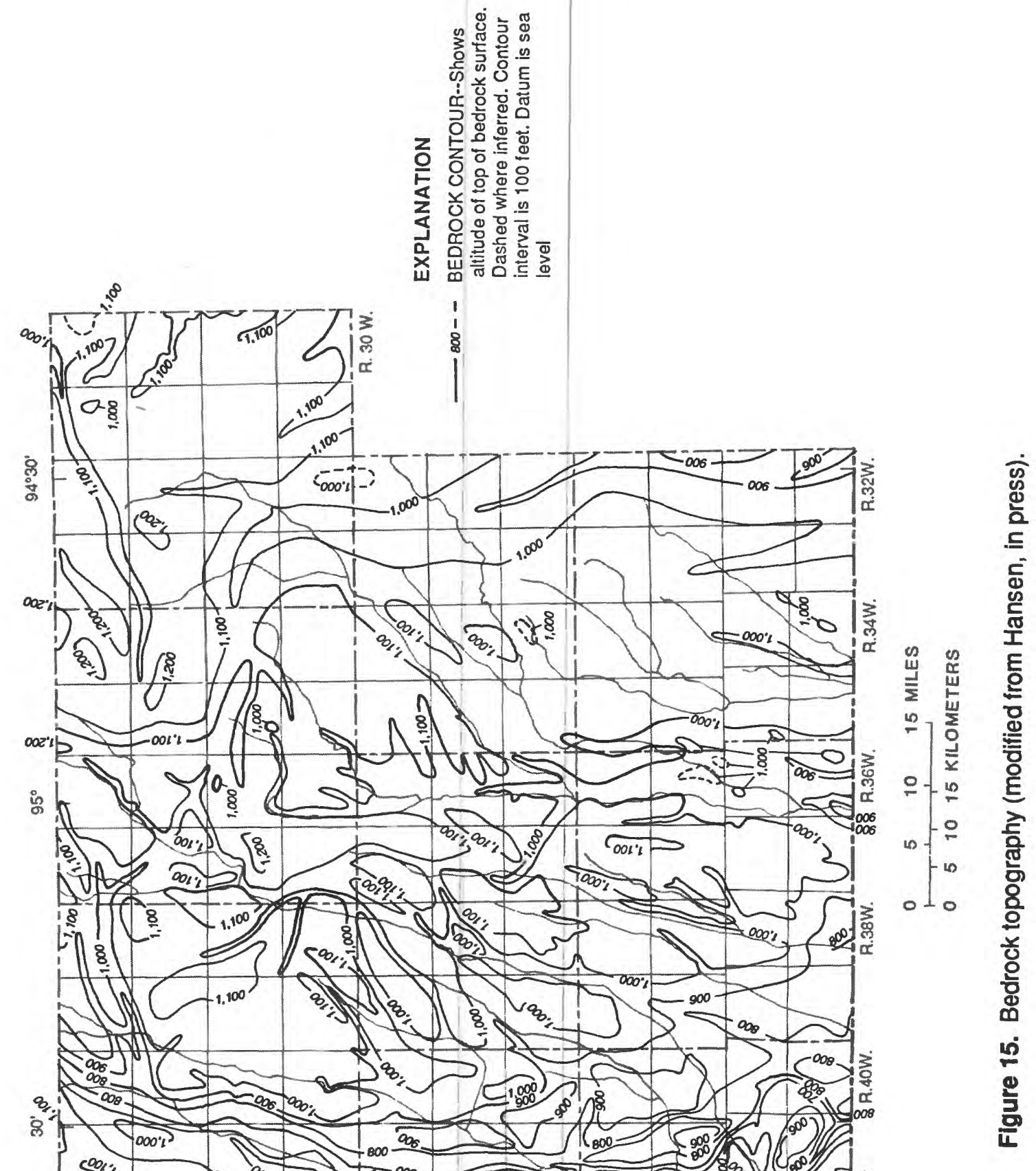


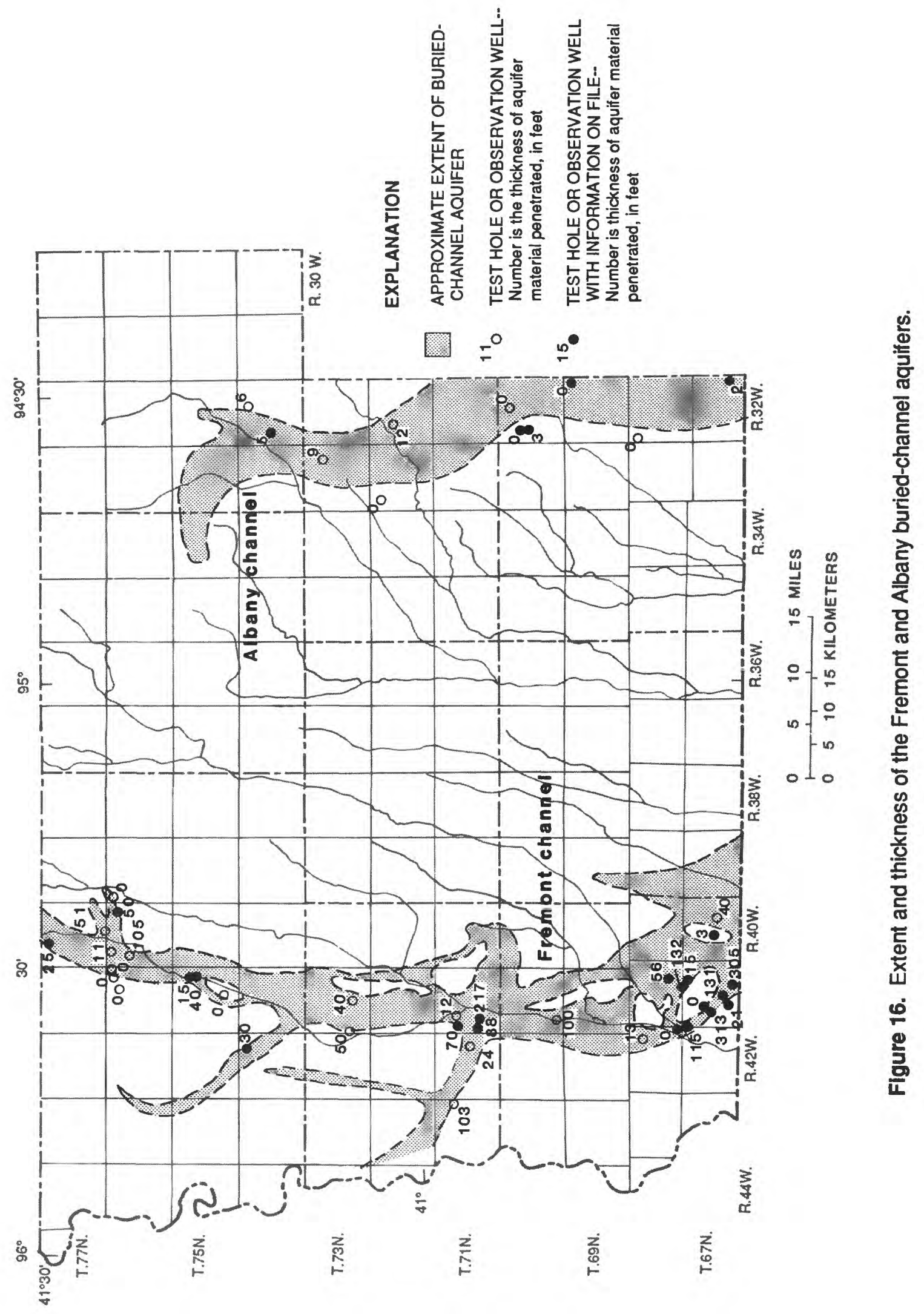


to determine the movement of water between these aquifers. Because of the discontinuous occurrence of the basal sand and gravel deposits, any exchange of water probably would have only local significance.

Most wells in the Fremont buried-channel aquifer are for rural use; however, the town of Treynor has wells that may be completed in the channel. Wells at Treynor, which range from 220 to $250 \mathrm{ft}$ deep, are pumped at rates between 80 and $150 \mathrm{gal} / \mathrm{min}$. On the basis of information from west-central Iowa (Runkle, 1987), the aquifer has an estimated transmissivity of $\mathbf{5 2 0}$ $\mathrm{ft}^{2} / \mathrm{d}$ and possible yields of $800 \mathrm{gal} / \mathrm{min}$. Although large yields are possible, testing usually is required to determine an appropriate yield for a particular area.

The Albany channel (fig. 16) is the upper part of a bedrock valley that contains sand and gravel deposits and extends farther south in Missouri. This valley trends northward from the southeast corner of Taylor County through Adams and into Adair and Cass Counties. Limited data are available for the Albany channel. According to local well drillers, the buried-channel aquifer underlies an area from southern Adair County southward through Taylor County. The existence of extensive sand and gravel deposits in the Albany channel is not indicated by available geologic logs and test-hole data. Previous work in south-central Iowa (Cagle and Heinitz, 1978) supports this conclusion. Sand and gravel deposits from 1 to $15 \mathrm{ft}$ thick have been recorded.

Water levels in the Albany buried-channel aquifer were measured in observation well SW78 (fig. 1; table 7). The altitude of the potentiometric surface in an inter-till aquifer at the same location, well SW83, was $5.35 \mathrm{ft}$ higher than the water level in the Albany buried-channel aquifer on August 8, 1988. This indicates a downward gradient at this location. As in the Fremont buried-channel aquifer, there probably is movement of ground water to the south and out of the area.

The town of Blockton in Taylor County obtains water from a well completed in the Albany buried-channel aquifer. Present pumpage for municipal use is about $15,000 \mathrm{gal} / \mathrm{d}$. The town of Fontanelle in Adair County has a stand-by well completed in the Albany buried-channel aquifer with a reported potential withdrawal rate of $40 \mathrm{gal} / \mathrm{min}$.

\section{Water Quality}

Analyses of water samples from the various glacial-drift aquifers (table 11) indicate that water from these aquifers generally is hard. Water from the inter-till and basal sand and gravel aquifers is usually of acceptable quality for most uses. Dissolved-solids concentrations ranged from 176 to $600 \mathrm{mg} / \mathrm{L}$, and sulfate concentrations ranged from 6.0 to $97 \mathrm{mg} / \mathrm{L}$. The water is generally a calcium bicarbonate type. However, water from observation well SW83 (table 8 ) is an exception. Water from this well is a sodium sulfate type, with a dissolved-solids concentration of $1,900 \mathrm{mg} / \mathrm{L}$ and sulfate concentration of $910 \mathrm{mg} / \mathrm{L}$. Iron concentrations have exceeded the secondary drinking-water regulations (table 4) and ranged from less than 10 to $8,000 \mu \mathrm{g} / \mathrm{L}$. Nitrate concentrations ranged from less than 0.10 to $120 \mathrm{mg} / \mathrm{L}$.

Water in the Fremont buried-channel aquifer ranged from a calcium bicarbonate type to a sodium sulfate type. Dissolved-solids concentrations in samples from the observation wells and the town of Treynor ranged from 312 to 1,410 $\mathrm{mg} / \mathrm{L}$, and sulfate concentrations ranged from 20 to $620 \mathrm{mg} / \mathrm{L}$ (table 8 ). Iron concentrations were large and exceeded the secondary drinking-water regulation. Nitrate concentrations generally were small, usually less than $1.0 \mathrm{mg} / \mathrm{L}$. Water in the Albany buried-channel aquifer is very hard with dissolved-solids concentrations ranging from 1,040 to $3,200 \mathrm{mg} / \mathrm{L}$ and sulfate concentrations from 240 to $1,900 \mathrm{mg} / \mathrm{L}$ (table 11 ). Iron concentrations generally exceeded the secondary drinking-water regulation. Nitrate concentrations were small, generally less than $0.50 \mathrm{mg} / \mathrm{L}$.

None of the common pesticides were detected in samples from any inter-till, basal sand and gravel, or buried-channel aquifer wells during this study (table 10). There are seven other analyses available for untreated municipal water and six from treated municipal water from these aquifers (M.L. Clark, U.S. Geological Survey, oral commun., 1989). A well at Emerson, completed in the basal sand and gravel aquifer, had a detection of chlordane at $0.10 \mu \mathrm{g} / \mathrm{L}$ during June 1986 from an untreated water sample. 


\section{Dakota Aquifer}

The Dakota aquifer consists of sandstone units within the Dakota Formation (table 6). In northwestern and west-central Iowa, the Dakota Formation consists of two members--the upper Woodbury Member, comprised of shale and sandstone, and the lower Nishnabotna Member, comprised of sandstone, gravel, and conglomerate. The Nishnabotna Member is the principal unit of the Dakota aquifer in these areas (Munter and others, 1983; Runkle, 1987). In southwest Iowa, the Dakota Formation generally consists of poorly cemented sandstone and gravel (Hershey and others, 1960) of the Nishnabotna Member (Witzke and Ludvigson, 1982).

\section{Occurrence}

The Dakota aquifer occurs primarily in Cass and Montgomery Counties (fig. 17). Outliers occur in Adair, Adams, Mills, and Pottawattamie Counties. Generally, identifiable Dakota Formation strata occur on bedrock uplands. In Cass and Montgomery Counties, it appears that the bedrock channels represent areas where the Dakota Formation was eroded. Thus, the Dakota Formation occurs as a group of isolated strata separated by bedrock channels.

The extent of the Dakota aquifer, as shown in figure 17, is different than previously published maps of the Cretaceous rocks in southwest Iowa (Hershey and others, 1960; Hershey, 1969; Witzke and Ludvigson, 1982). Presently (1991) available information indicates that the Dakota aquifer is more dissected and restricted than previously mapped. Interpretation of its extent is difficult because there are many drillers' logs that do not distinguish sand from sandstone. Also, some test holes may have stopped short of penetrating the Dakota aquifer beneath Dakota Formation shale.

The Dakota aquifer varies in thickness from a few feet to $140 \mathrm{ft}$, although the average thickness in most areas varies between 20 and $60 \mathrm{ft}$ (fig. 17). The maximum probable thickness of the Dakota Formation in southwest Iowa is less than $150 \mathrm{ft}$ because the formation is at the eastern edge of its geographic limit. Also, in several counties north of the study area, the maximum measured thickness is reported to be $150 \mathrm{ft}$ (Runkle, 1987).

The top of the Dakota aquifer is generally at higher altitudes, $1,150 \mathrm{ft}$ to more than $1,200 \mathrm{ft}$ in the north and northeast and at slightly lower altitudes, $1,100 \mathrm{ft}$ to less than $1,050 \mathrm{ft}$, toward the south and west. The Dakota Formation crops out along some streams in Cass and Montgomery Counties.

The potentiometric surface generally declines from the northeast to the southwest and also toward all major rivers (fig. 18). In northern Montgomery County, anomalously high water levels occur in an area between the East Nishnabotna and Tarkio Rivers. The water level in one well exceeded $1,250 \mathrm{ft}$, about $150 \mathrm{ft}$ to 200 $\mathrm{ft}$ higher than other water levels in this area and adjacent areas of the Dakota aquifer. Yields to wells completed in the Dakota aquifer have been reported as large as $150 \mathrm{gal} / \mathrm{min}$, but more typical values are about $20 \mathrm{gal} / \mathrm{min}$. The hydraulic characteristics of parts of the Dakota aquifer in southwest Iowa are listed in table 15 at the back of this report.

\section{Water Quality}

Water from the Dakota aquifer is a calcium bicarbonate type (fig. 19), with magnesium a significant secondary cation and sulfate a significant secondary anion. In samples from municipal wells at Anita, sodium and magnesium are more common secondary cations than in the other samples. Water-quality data from nine municipalities in southwest Iowa using the Dakota aquifer are summarized in table 16 at the back of this report.

Water from the Dakota aquifer is hard to very hard, with total hardness ranging from 112 to $640 \mathrm{mg} / \mathrm{L}$ as calcium carbonate (table 16). Sulfate concentrations, although generally less than $50 \mathrm{mg} / \mathrm{L}$, were as large as $430 \mathrm{mg} / \mathrm{L}$ in some areas. Only one sample exceeded the secondary drinking-water regulation of $250 \mathrm{mg} / \mathrm{L}$ for sulfate (table 3). Dissolved-solids concentrations rarely exceeded the secondary drinking-water regulation of $500 \mathrm{mg} / \mathrm{L}$ (table 3 ), and averaged about $325 \mathrm{mg} / \mathrm{L}$ throughout the area. Water from the Dakota aquifer in the Anita area contained larger dissolved-solids concentrations than any other area in southwest Iowa; specific conductance averaged $877 \mu \mathrm{S} / \mathrm{cm}$ (microsiemens 


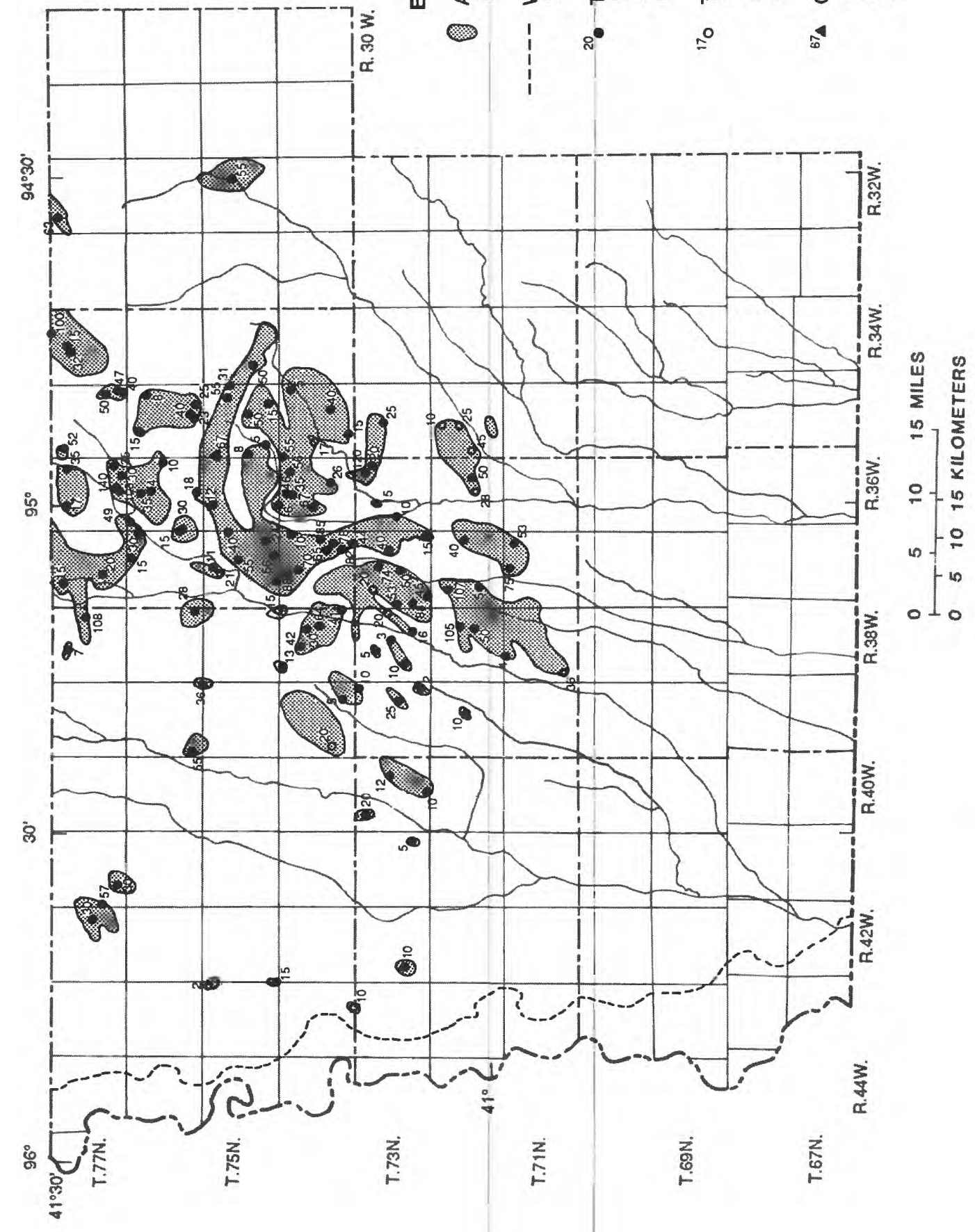




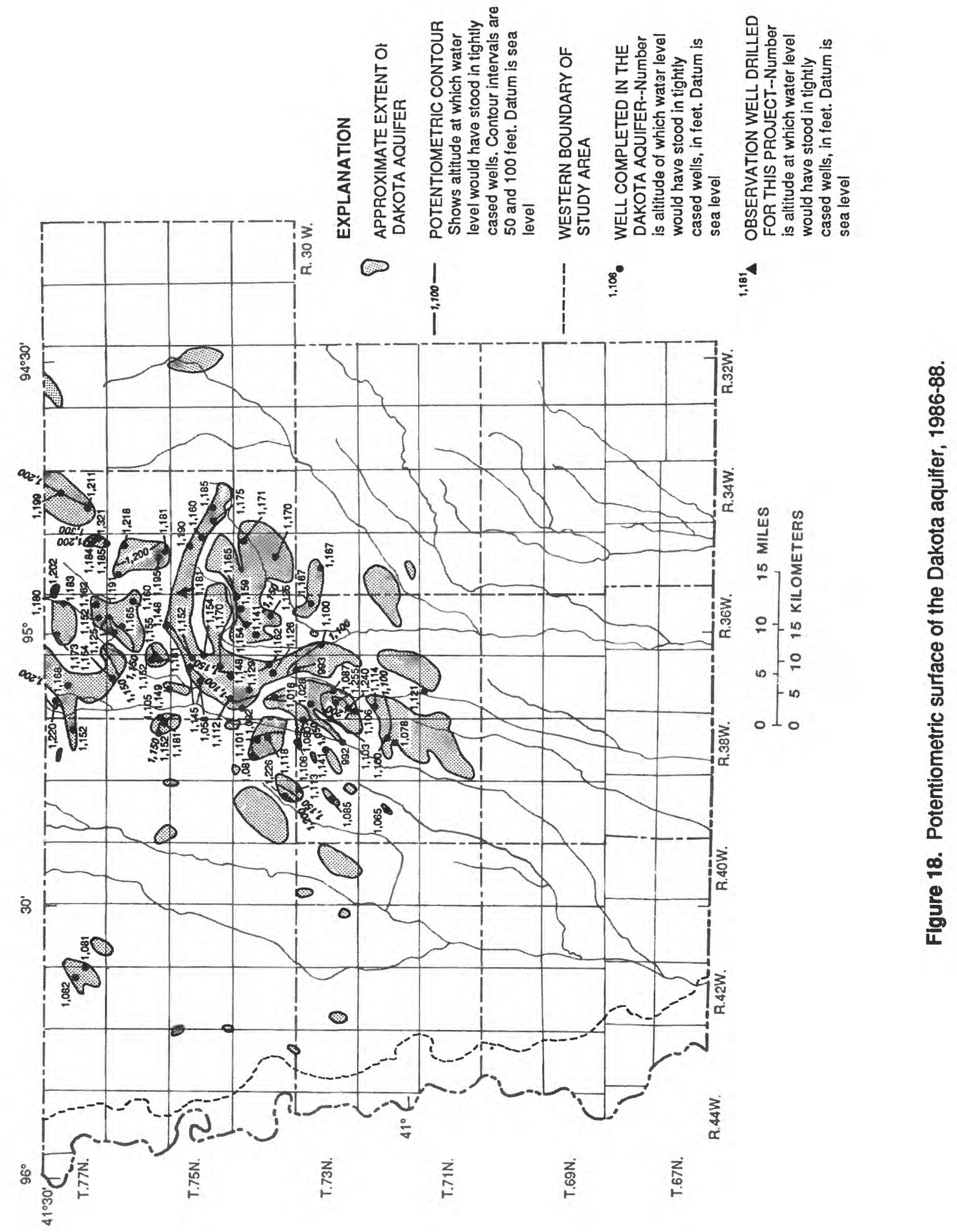




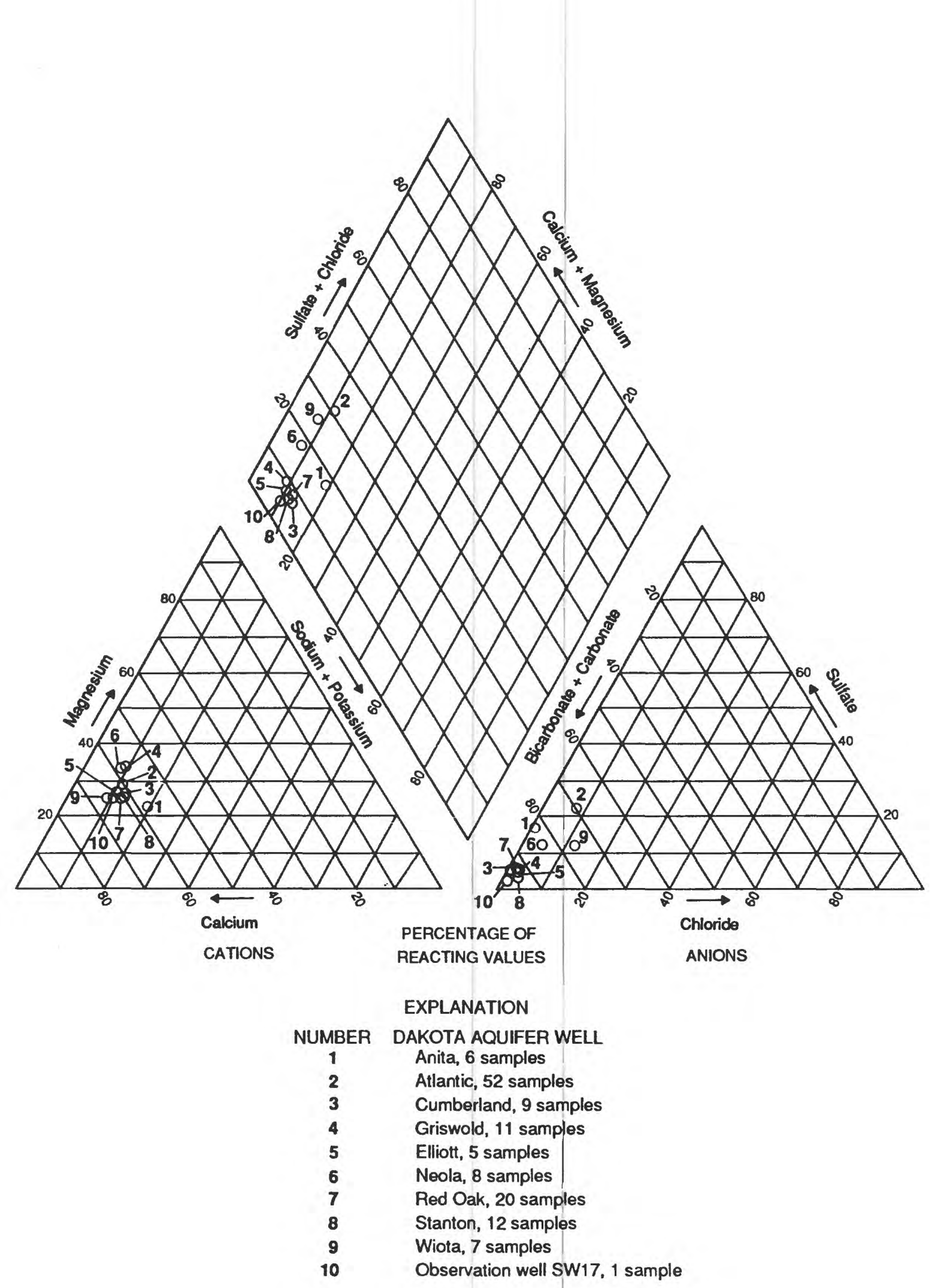

Figure 19. Historical water quality of the Dakota aquifer, 1950-86. 
per centimeter at 25 degrees Celsius), sulfate averaged $162 \mathrm{mg} / \mathrm{L}$, and dissolved-solids concentrations averaged $619 \mathrm{mg} / \mathrm{L}$. Iron exceeded the secondary drinking-water regulations (table 3 ) in water from wells in four municipalities and ranged from less than 10 to $16,000 \mu \mathrm{g} / \mathrm{L}$. Nitrate concentrations were about 3 $\mathrm{mg} / \mathrm{L}$ throughout the area; 7 of 127 reported analyses exceeded the primary drinking-water regulation of $10 \mathrm{mg} / \mathrm{L}$. The largest nitrate concentration reported was $13 \mathrm{mg} / \mathrm{L}$. Atrazine, the only pesticide detected in Dakota aquifer water samples, was detected in a water sample from Atlantic at a concentration of $0.39 \mu \mathrm{g} / \mathrm{L}$ in January 1987. There were no other pesticide detections in10 raw-water samples.

Barium, copper, and zinc were the most common trace elements detected in water from the Dakota aquifer; concentrations ranged from less than 10 to $800 \mu \mathrm{g} / \mathrm{L}$, less than 10 to $170 \mu \mathrm{g} / \mathrm{L}$, and less than 10 to $940 \mu \mathrm{g} / \mathrm{L}$, respectively (table 16 at the back of this report). Concentrations of other trace elements detected included: selenium, 2 samples at the MCL of $10 \mu \mathrm{g} / \mathrm{L}$; arsenic, 3 samples at $10 \mu \mathrm{g} / \mathrm{L}$; cadmium, 1 sample at $4 \mu \mathrm{g} / \mathrm{L}$; and lead, 1 sample at $20 \mu \mathrm{g} / \mathrm{L}$. The detection level for some of the metals analyzed also is the MCL for drinking water. Radium-226 has been detected, with concentrations ranging from 0.6 to $4.0 \mathrm{pCi} / \mathrm{L}$ (picocuries per liter), and radium-228 has been detected, with concentrations ranging from 1.3 to $1.8 \mathrm{pCi} / \mathrm{L}$ (table 16).

\section{WATER USE}

The major categories of water use in southwest Iowa are municipal, rural domestic, livestock, irrigation, and industrial/commercial (referred to as industrial in this report). Municipal water-use information, which includes rural-water systems, was collected by U.S. Geological Survey personnel from individual water-plant operators where possible or compiled from the files of the Iowa Department of Natural Resources. Estimates of the other water-use quantities were based on the permitted-use quantity or on use rates applied to population estimates. Estimates of the quantity of use for each category are listed in table 17 at the back of this report. Although the date of the annual water-use estimate varies slightly from one category to another, changes in use do not vary substantially from one year to the next, and the data are considered adequate for comparison between the categories for the purposes of this report.

\section{Municipal Use, 1984}

Municipal water use is the third largest use of water in southwest Iowa (table 17). The largest municipal use in 1984, about $9.3 \mathrm{Mgal} / \mathrm{d}$, occurred in Pottawattamie County. The smallest use of less than $0.3 \mathrm{Mgal} / \mathrm{d}$ in 1984 was in Adams County. Ground-water resources supplied more than 60 percent of the water used for municipal purposes. The location, source, and relative quantity of withdrawal are shown in figure 20. Several municipalities and rural-water systems derive their water from or are located outside the study area. Additional information on the sources of water, population served, average use, and maximum use for each municipality and rural-water system is provided in table 18 at the back of this report.

Total maximum daily water use by municipal and rural-water systems, about $35 \mathrm{Mgal} / \mathrm{d}$, is slightly more than double the average daily water use (table 17). For several communities, maximum water use is reported as four to seven times higher than average use (table 18). Water authorized for municipal use is generally restricted to a maximum of $2,000 \mathrm{gal} / \mathrm{d}$ per capita [State of Iowa Administrative Code (567), Ch. $52.2(3)]$.

\section{Rural Domestic Use, 1984}

Rural domestic water use is the quantity of water used by households not served by municipal or rural-water systems. Rural domestic water use (table 17) is estimated at 100 gal/d per capita. Rural domestic water supplies generally are dependent on shallow groundwater sources. In 1984, the largest rural domestic water use, about $1.8 \mathrm{Mgal} / \mathrm{d}$, occurred in Pottawattamie County. This use is larger than the 1984 average municipal water use for seven of the nine counties in the study area.

\section{Livestock Use, 1986}

Livestock data are from Iowa Department of Agriculture and Land Stewardship (1987), and livestock water requirements are from Herrick 

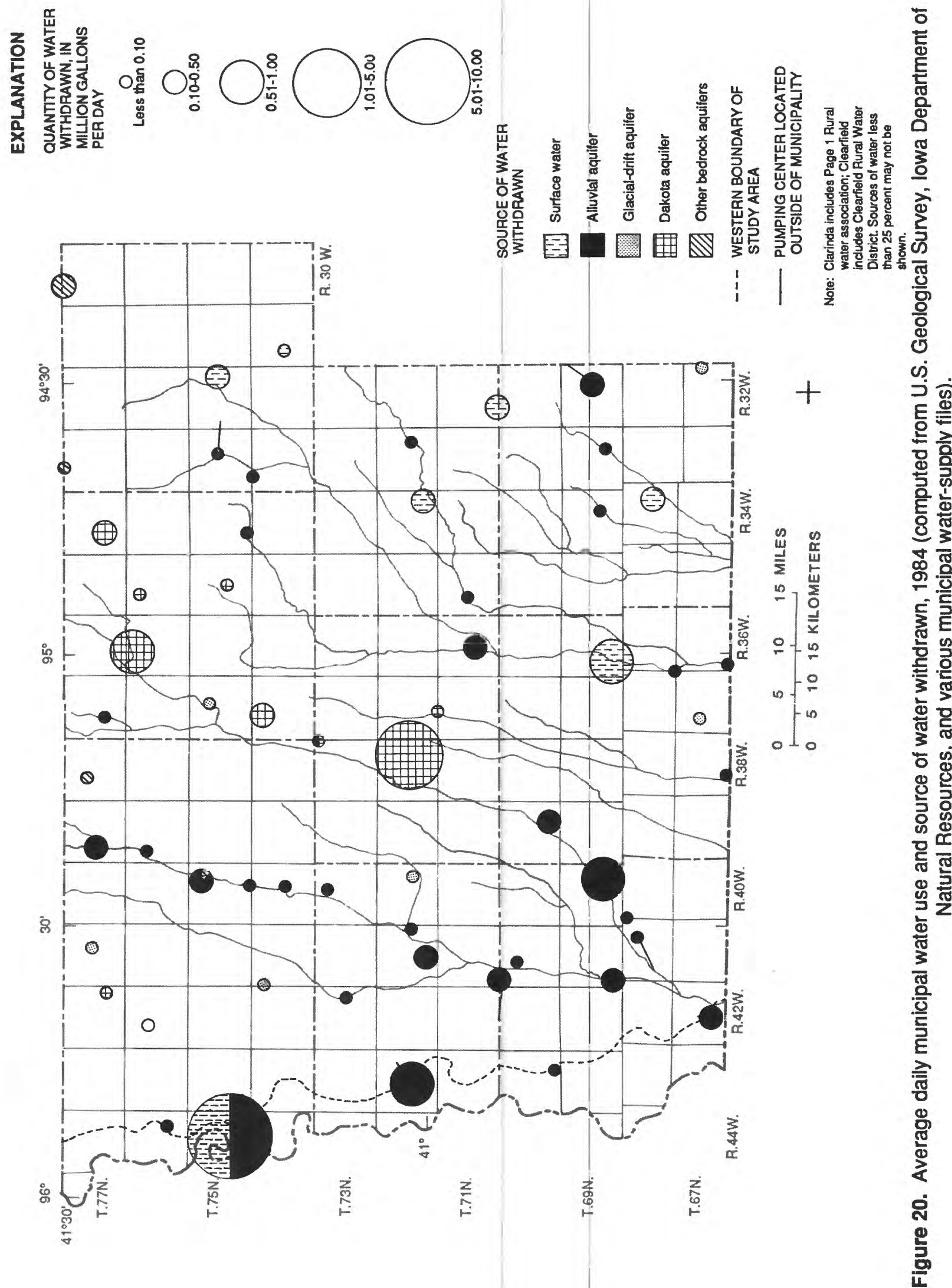
(1978). Livestock water use (table 17) will vary depending on current farm inventories. During the past few years there has been a decline in farm inventories in Iowa (Iowa Department of Agriculture and Land Stewardship, 1987). Although farm ponds are sources of surface water for some of the livestock population, no attempt was made to categorize these sources. Generally, water for livestock use in southwest Iowa is from shallow ground-water sources.

\section{Permitted Water Use, 1987}

Existing water-withdrawal permits for irrigation, industrial (including electricgeneration cooling water), commercial feedlots, and miscellaneous uses are listed in table 17. Permits for municipal water supplies are not included. Permitted water use is the maximum quantity of water allowed to be withdrawn. Because actual water-use withdrawals vary yearly for certain categories, permitted water-use data are discussed in the following sections.

\section{Irrigation}

Irrigation permits are issued for seasonal withdrawals for general farm crops, such as row crops, small grain, and hay from April 1 to September 30 , and specialty crops, such as vegetables, fruits, and sod from April 1 to October 31 [State of Iowa Administrative Code (567), Ch. 52.2(1)a]. General farm crops may be authorized 1 acre-ft, and specialty crops may be authorized 2 acre- $\mathrm{ft}$ [State of Iowa Administrative Code (567), Ch. 52.2(1)b].

In southwest Iowa, 75 percent or $20.3 \mathrm{Mgal} / \mathrm{d}$ of water permitted for irrigation use comes from ground water. Approximately 97 percent of the ground water used for irrigation, $19.6 \mathrm{Mgal} / \mathrm{d}$, is derived from alluvial aquifers along the principal rivers, primarily the Missouri River. This quantity is nearly double the quantity of water used by municipal systems and industrial permits from alluvial aquifers (table 17).

\section{Industrial}

The permitted industrial use of water is predominantly from surface-water resources ( 83 percent of the total industrial use). Use of surface water for industrial purposes occurs mainly in Adair, Adams, Cass, Page, and
Pottawattamie Counties. Ground water for industrial purposes is used mainly in Pottawattamie County.

\section{Commercial Feedlots}

Feedlots are permitted commercial water users. Water used by feedlots was subtracted from the total permitted water use in calculating total water use to prevent counting water used by livestock twice. Commercial feedlots account for about 8 percent of total livestock water use in the study area (table 17).

\section{Miscellaneous}

The principal miscellaneous permitted water user in the nine-county area is the Iowa Department of Natural Resources, which has a permitted use for recreational purposes of 9.13 $\mathrm{Mgal} / \mathrm{d}$ or 87 percent of this category. The quantity of water authorized for recreational and also other purposes is determined on the basis of the proposed use [State of Iowa Administrative code (567), Ch. 52.2(4)].

\section{Total Water Use}

Total water use in southwest Iowa is about $91.8 \mathrm{Mgal} / \mathrm{d}$ (table 17). The largest use is for irrigation, 26.9 Mgal/d. Pottawattamie County uses 35 percent of the total water in southwest Iowa and more than twice as much water as the next largest water user, Fremont County. The proportion of total water use in southwest Iowa for each category of use is shown in figure 21. The proportion of total water use in each county for each category of use is shown in figure 22.

Domestic use, including municipal- and rural-water systems and rural domestic use, accounts for about $22.0 \mathrm{Mgal} / \mathrm{d}$ or 24 percent of total water use in southwest Iowa. Livestock use accounts for $10.3 \mathrm{Mgal} / \mathrm{d}$ or 11.2 percent of total water use; $26.9 \mathrm{Mgal} / \mathrm{d}$ or 29.4 percent of the total water use is for irrigation; $22.1 \mathrm{Mgal} / \mathrm{d}$ or 24 percent of the total use is for industrial use; and about $10.5 \mathrm{Mgal} / \mathrm{d}$ or 11.4 percent of the total use is for miscellaneous permitted water uses, primarily recreation. More than 55 percent or $51.2 \mathrm{Mgal} / \mathrm{d}$ of the total water use in southwest Iowa is from ground-water sources if livestock are assumed to be totally dependent on ground-water sources. 


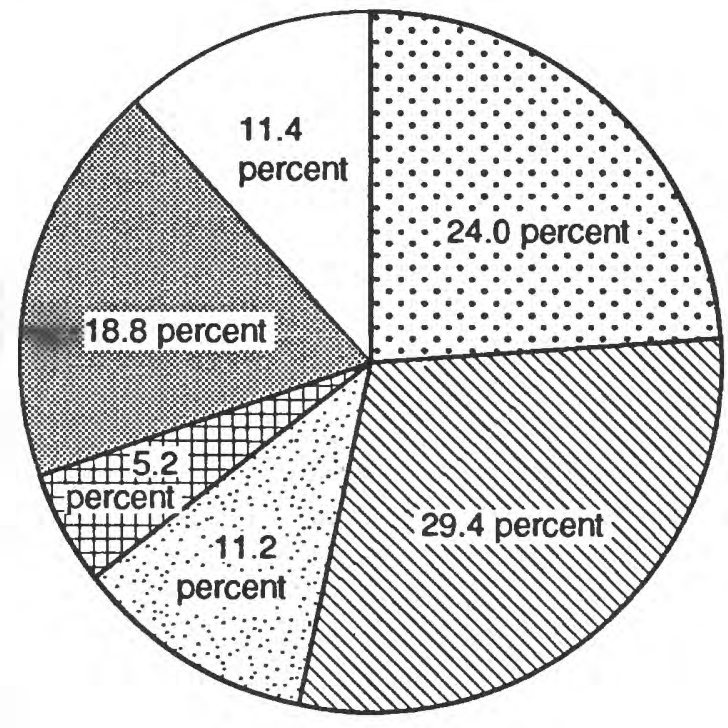

\section{EXPLANATION}

WATER USE

Industrial, excluding thermoelectric-power generation from the Missouri River

Irrigation

Livestock

Rural domestic

Municipal- and rural-water systems

Miscellaneous permitted, includes recreation

Figure 21. Total water use (compiled from U.S. Geological Survey, lowa Department of Natural Resources, and various municipal water-supply files).

\section{Surface Water}

Surface-water use within the study area accounts for $34.4 \mathrm{Mgal} / \mathrm{d}$ or 44.3 percent of total water use. These uses are irrigation, $6.6 \mathrm{Mgal} / \mathrm{d}$ or 7.2 percent of the total use; industrial, 18.3 $\mathrm{Mgal} / \mathrm{d}$ or 19.9 percent of the total use; miscellaneous, $9.3 \mathrm{Mgal} / \mathrm{d}$ or 10.1 percent; and commercial feedlots, $0.2 \mathrm{Mgal} / \mathrm{d}$ or less than 1 percent of the total use. Additionally, municipaland rural-water systems using surface water account for $6.3 \mathrm{Mgal} / \mathrm{d}$ or 6.9 percent of all water used in the study area. Rural domestic and livestock are not substantially dependent on surface-water sources, although livestock use of farm ponds does occur.

\section{Ground Water}

Municipal- and rural-water systems using ground water account for $10.9 \mathrm{Mgal} / \mathrm{d}$ or 11.9 percent of total water use in the study area, and permitted irrigation, industrial, and miscellaneous ground-water use accounts for 25.2 $\mathrm{Mgal} / \mathrm{d}$ or 27.5 percent of total water use. It is assumed that rural domestic, which accounts for 4.8 Mgal/d, and livestock, which accounts for 10.3 $\mathrm{Mgal} / \mathrm{d}$ (5.2 and 11.2 percent of the total water use), are substantially dependent on ground-water sources.

Alluvial aquifers are the most important source of ground water in the study area. Alluvial sources supply approximately 97 percent or $19.6 \mathrm{Mgal} / \mathrm{d}$ of permitted ground water used for irrigation; 100 percent or $3.8 \mathrm{Mgal} / \mathrm{d}$ of the permitted ground water for industrial use; about 34 percent or $0.23 \mathrm{Mgal} / \mathrm{d}$ of permitted ground water for commercial feedlots; and about 98.6 percent or $1.15 \mathrm{Mgal} / \mathrm{d}$ of permitted ground water for miscellaneous uses. About 44 percent, 7.6 $\mathrm{Mgal} / \mathrm{d}$, of the municipal- and rural-water system use of ground water is derived from alluvial aquifers.

The Dakota aquifer is mainly used for domestic and municipal water supplies. Although nine municipalities rely on the Dakota aquifer, in part, for their water supplies (table 18), Red Oak and Atlantic are the principal users 


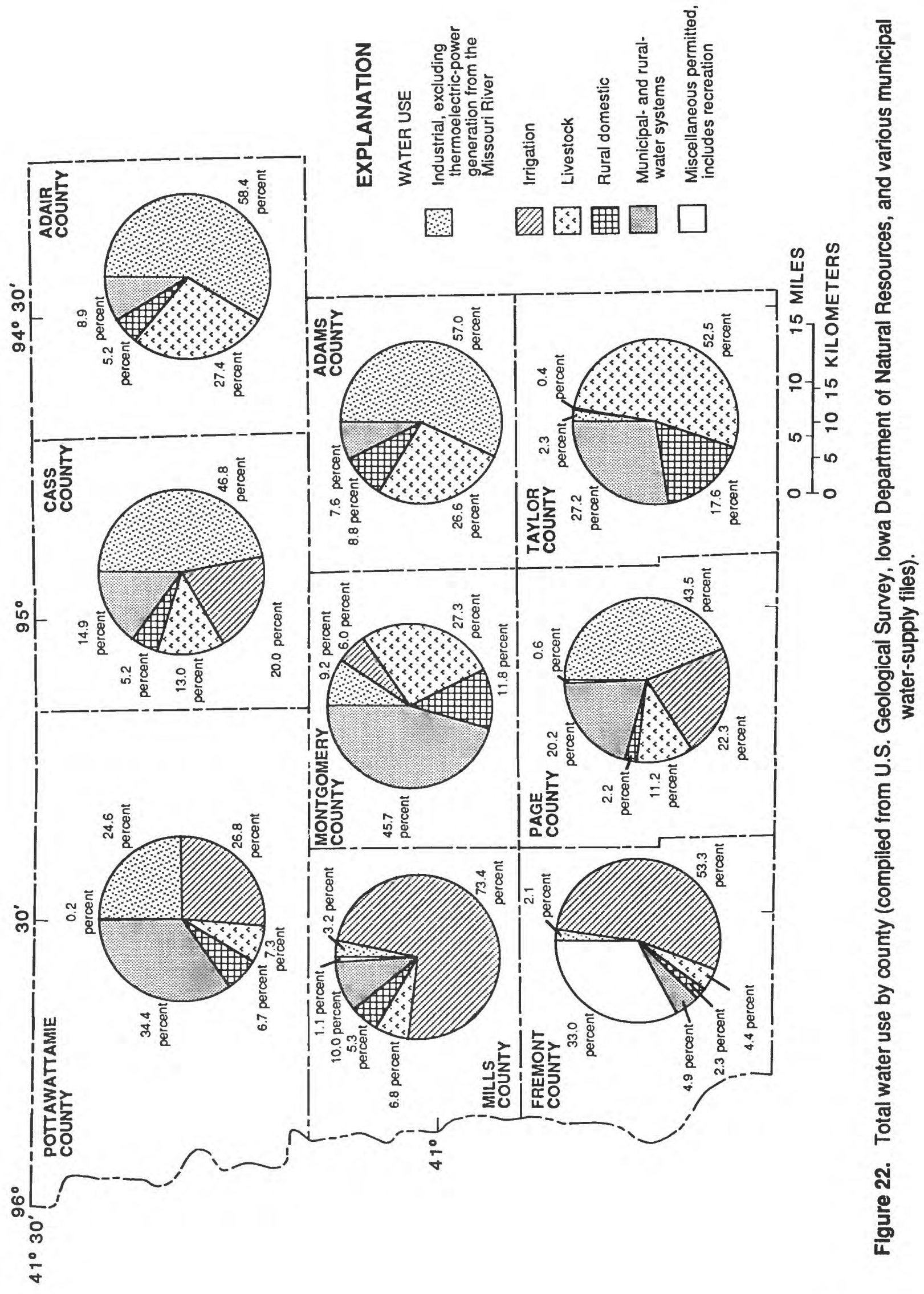


of the Dakota aquifer with withdrawals of about $1 \mathrm{Mgal} / \mathrm{d}$ each. Total municipal water use from the Dakota aquifer is $2.63 \mathrm{Mgal} / \mathrm{d}$, which is about 3 percent of total water use.

\section{Future Water Demands}

Future demands for water in the study area probably will be met by increased use of surface-water sources and alluvial aquifers, particularly the Missouri River alluvial aquifer. The users that are already dependent on the Dakota aquifer will continue to rely on it. There may be some slight shift for the rural domestic and livestock users to use buried-channel deposits if these sources become better known, can provide adequate yields, and have acceptable water quality.

\section{SUMMARY}

Residents in southwest Iowa rely on shallow ground-water sources because of unacceptable water quality in deeper aquifers. These shallow aquifers are of limited extent, the water levels and thus the quantity of water in storage, are affected by climatic variations, and the aquifers are susceptible to contamination. Analyses of samples from private water wells from 1981 to 1986 indicate that wells in southwest Iowa have larger nitrate concentrations than wells in other parts of the State. An appraisal of the ground-water resources of a nine-county area in southwest Iowa was done to provide information needed to plan the development of the shallow water resources. Five types of unconsolidated aquifers and one bedrock aquifer were investigated.

Alluvial aquifers, comprised of sand and gravel, are present in the major river valleys. Four alluvial aquifers were investigated--the Nishnabotna, Nodaway, Tarkio, and One Hundred and Two. Alluvial deposits in southwest Iowa usually consist of a series of fine-grained deposits overlying sand and gravel.

The Nishnabotna alluvial aquifer is the most used source for municipal and domestic water. The alluvial deposits are variable; the average thickness of the fine-grained materials is $21 \mathrm{ft}$, overlying an average thickness of $17 \mathrm{ft}$ of sand and gravel. Transmissivities range from 1,000 to
$8,000 \mathrm{ft}^{2} / \mathrm{d}$, and most wells are capable of yielding as much as $100 \mathrm{gal} / \mathrm{min}$ of water.

Water in the Nishnabotna alluvial aquifer is a calcium bicarbonate type. Nitrate concentrations are variable and have exceeded the MCL in samples from several municipal wells. Iron concentrations greater than the secondary drinking-water regulation of $300 \mu \mathrm{g} / \mathrm{L}$ are common. Pesticides were detected in water from nine municipal wells; none were detected in water from observation wells. Five pesticides were detected; concentrations for all pesticides except alachlor were less than proposed regulations.

The Nodaway alluvial aquifer also is an important source of water, although less used than the Nishnabotna alluvial aquifer. The average thickness of the fine-grained alluvial sediments is about $20 \mathrm{ft}$, overlying an average thickness of about $10 \mathrm{ft}$ of sand and gravel. Transmissivities range from 90 to $570 \mathrm{ft}^{2} / \mathrm{d}$, and yields range from 12 to $100 \mathrm{gal} / \mathrm{min}$.

Water in the Nodaway alluvial aquifer is a calcium bicarbonate type. Nitrate concentrations generally are less than in the Nishnabotna alluvial aquifer. Iron concentrations commonly exceeded the secondary drinking-water regulation. One municipal well had detectable concentrations of two pesticides.

The other two alluvial aquifers, the Tarkio and the One Hundred and Two, are used less. Their limited areal extent and thin sand and gravel deposits limit their productivity to yields generally less than $50 \mathrm{gal} / \mathrm{min}$. Both aquifers contain calcium bicarbonate type water. Nitrate concentrations are small, generally less than 1.0 $\mathrm{mg} / \mathrm{L}$. Pesticides have been detected in samples from municipal wells completed in each aquifer.

There are four types of glacial-drift aquifers in southwest Iowa--loess, inter-till sand and gravel, basal sand and gravel, and buried-channel sand and gravel. Except for buried channels, these aquifers are discontinuous and distributed locally. Wells completed in loess and inter-till sand and gravel are used by rural residents, who commonly use large-diameter seepage wells to obtain water from these low-yield sources. The inter-till and basal sand and gravel aquifers are used by a few municipalities. Yields to wells screened in these aquifers are variable. Loess 
wells typically yield less than $10 \mathrm{gal} / \mathrm{min}$, and inter-till and basal sand and gravel aquifers yield from 10 to $120 \mathrm{gal} / \mathrm{min}$.

There are two buried-channel aquifers in the study area--the Fremont and Albany. The Fremont buried-channel aquifer is the most extensive and contains sand and gravel deposits about $300 \mathrm{ft}$ thick. The Albany buried-channel aquifer is less extensive, with thinner sand and gravel deposits. Only one municipality relies on water from a buried-channel aquifer; the town of Blockton in Taylor County has a well in the Albany buried-channel aquifer. Well yields from these buried-channel aquifers range from 40 to $150 \mathrm{gal} / \mathrm{min}$.

Water from the loess and inter-till and basal sand and gravel aquifers is normally a calcium bicarbonate type. Nitrate concentrations in some samples exceeded the MCL. Iron concentrations have exceeded the secondary drinking-water regulation. No agricultural pesticides were detected; however, chlordane was detected in water from one municipal well completed in the basal sand and gravel aquifer.

Water in the buried-channel aquifers ranged from a calcium bicarbonate type to a sodium sulfate type. Sulfate, dissolved-solids, and iron concentrations in some samples exceeded the secondary drinking-water regulations. Nitrate concentrations were small, usually less than $\mathbf{1 . 0}$ $\mathrm{mg} / \mathrm{L}$, and no pesticides were detected in samples collected during this study.

The Dakota aquifer was the only bedrock aquifer investigated. In southwest Iowa, the Dakota aquifer exists as isolated outliers, primarily in Montgomery and Cass Counties. The thickness of the aquifer is variable, averaging between 20 and $60 \mathrm{ft}$. Yields to Dakota aquifer wells are quite variable. Water from the aquifer is a calcium bicarbonate type. Sulfate and dissolved-solids concentrations rarely exceeded the secondary drinking-water regulations, whereas iron concentrations often exceeded the secondary drinking-water regulation. Nitrate concentrations were small, usually about $3.0 \mathrm{mg} / \mathrm{L}$, and pesticides were detected at only one municipal well.

Water-use statistics were tabulated for each county in southwest Iowa. Municipal- and rural-water systems rely primarily on surface water (37 percent), alluvial aquifers (44 percent), and the Dakota aquifer (15 percent). Rural residents rely on the alluvial and glacial-drift aquifers, although actual use data are not available.

\section{SELECTED REFERENCES}

Bettis, E.A., III, and Littke, J.P., 1987, Holocene alluvial stratigraphy and landscape development in Soap Creek watershed, Appanoose, Davis, Monroe, and Wapello Counties, Iowa: Iowa City, Iowa Department of Natural Resources, Geological Survey Bureau Open-File Report 87-2, 170 p.

Bruner, D.R., and Hallberg, G.R., 1987, An overview of water quality in the Skunk River basin: Iowa City, Iowa Department of Natural Resources, Geological Survey Bureau Open-File Report 87-3, 36 p.

Cagle, J.W., and Heinitz, A.J., 1978, Water resources of south-central Iowa: Iowa City, Iowa Geological Survey Water Atlas 5, $97 \mathrm{p}$.

Dorsch, M.M., Scragg, R.K., McMichael, A.J., Baghurst, P.A., and Dyer, K.F., 1984, Congenital malformations and maternal drinking water supply in rural South Australia--A case control study: American Journal of Epidemiology, v. 119, p. 473-486.

Forman, D., Al-Dabbagh, S., and Doll, R., 1985, Nitrates, nitrites, and gastric cancer in Great Britain: Nature, v. 313, p. 620-625.

Fraser, P., and Chilvers, C., 1981, Health aspects of nitrate in drinking water: Science of the Total Environment, v. 18, p. 103-116.

Freeze, R.A., and Cherry, J.A., 1979, Groundwater: Englewood Cliffs, New Jersey, Prentice-Hall, $604 \mathrm{p}$.

Hallberg, G.R., and Hoyer, B.E., 1982, Sinkholes, hydrogeology and groundwater quality in northeast Iowa: Iowa City, Iowa Geological Survey Open-File Report 82-3, 120 p. 
Hallberg, G.R., Hoyer, B.E., Bettis, E.A., III, and Libra, R.D., 1983, Hydrogeology, water quality, and land management in the Big Spring basin, Clayton County, Iowa: Iowa City, Iowa Geological Survey Open-File Report 83-3, 280 p.

Hansen, R.E., in press, Bedrock topography of southwest Iowa: U.S. Geological Survey Miscellaneous Map Series Report I-1222, 1 sheet.

Herrick, J.B., 1978, Water quality for livestock: Ames Cooperative Extension Service, Iowa State University, Animal Health Fact Sheet no. $8,1 \mathrm{p}$.

Hershey, H.G., 1969, Geologic map of Iowa: Iowa City, Iowa Geological Survey, scale 1:500,000, 1 sheet.

Hershey, H.G., Brown, C.N., Van Eck, O., and Northrup, R.C., 1960, Highway construction materials from the consolidated rocks of southwestern Iowa: Ames, Iowa Highway Research Board Bulletin 15, 151 p.

Iowa Department of Agriculture and Land Stewardship, 1987, Iowa agricultural statistics: Des Moines, 111 p.

Knochenmus, D.D., 1962, Alluvial history of the Nishnabotna valley, southwestern Iowa: Ames, Iowa State University, unpublished M.S. thesis, 76 p.

Libra, R.D., Hallberg, G.R., and Hoyer, B.E., 1984, Groundwater quality and hydrogeology of Devonian carbonate aquifers in Floyd and Mitchell Counties, Iowa: Iowa City, Iowa Geological Survey Open-File Report 84-2, 106 p.

Munter, J.A., Ludvigson, G.A., and Bunker, B.J., 1983, Hydrogeology and stratigraphy of the Dakota Formation in northwest Iowa: Iowa City, Iowa Geological Survey Water Supply Bulletin 13, 55 p.

National Oceanic and Atmospheric Administration, 1987, Monthly reports for Iowa, 1986-87: Asheville, N.C., Environmental Data Service, 27 p.
Prior, J.C., 1976, A regional guide to Iowa landforms: Iowa City, Iowa Geological Survey Educational Series 3, 72 p.

Ruhe, R.V., 1969, Quaternary landscapes in Iowa: Ames, Iowa State University Press, 255 p.

Runkle, D.L., 1987, Hydrology of the alluvial, buried channel, basal Pleistocene and Dakota aquifers in west-central Iowa: U.S. Geological Survey Water-Resources Investigations Report 85-4239, $111 \mathrm{p}$.

State of Iowa Administrative Code (567), Chapters 37, 38, 39, 51, 52, 54.

Stone, R., 1971, Hydrogeology of the Nishnabotna River basin: Ames, Iowa State University, unpublished Ph.D. dissertation, $179 \mathrm{p}$.

Thompson, C.A., 1986, Water resources of the Ocheyedan--Little Sioux alluvial aquifer: Iowa City, Iowa Department of Natural Resources, Geological Survey Bureau Open-File Report 86-3, 90 p.

1987, Water resources of the Rock River alluvial aquifer: Iowa City, Iowa Department of Natural Resources, Geological Survey Bureau Open-File Report 87-1, 109 p.

Thompson, C.A., and VanDorpe, P.E., 1988, Water quality monitoring of the Nishnabotna River alluvial system: Iowa City, Iowa Department of Natural Resources, Geological Survey Bureau Open-File Report 88-1, 61 p.

U.S. Environmental Protection Agency, 1987, Agricultural chemicals in ground water--Proposed pesticide strategy: Office of Pesticides and Toxic Substances, 149 p.

1988a, Maximum contaminant levels (subpart B of part 141, National interim primary drinking-water regulations): U.S. Code of Federal Regulations, Title 40, Parts 100 to 149 , revised as of July 1,1988 , p. 530-583. 
1988b, National revised primary drinking-water regulations--Maximum contaminant levels (subpart $G$ of part 141, National interim primary drinking-water regulations): U.S. Code of Federal Regulations, Title 40, Parts 100 to 149, revised as of July 1, 1988, p. 586-587.

1988c, Secondary maximum contaminant levels (section 143.3 of part 143, National secondary drinking-water regulations): U.S. Code of Federal Regulations, Title 40, Parts 100 to 149 , revised as of July 1,1988, p. 608 .

1988d, Proposed rule, drinking-water regulations--Maximum contaminant level goals and national primary drinking-water regulations for lead and copper (subpart I of part 141): U.S. Federal Register, v. 53, no. 160 , August 18, 1988, p. $31,516-31,578$.

1989, Proposed rule, National primary and secondary drinking-water regulations (sections 141.50, 141.51, 141.61, and 141.62 of part 141 and 143.3 of part 143): U.S. Federal Register, v. 54, no. 97, May 22, 1989, p. 22,062-22,160.

Walton, W.C., 1960, Selected analytical methods for well and aquifer evaluation: Champaign, Illinois State Water Survey Bulletin 49, 81 p.

Wehmeyer, L.K., 1988, Denitrification and nitrate movement in the shallow alluvial aquifer of the West Des Moines River, Palo Alto County, Iowa: Iowa City, University of Iowa, unpublished M.S. thesis, $110 \mathrm{p}$.

Witzke, B.J., and Ludvigson, G.A., 1982, Cretaceous stratigraphy and depositional systems in Guthrie County, Iowa: Geological Society of Iowa Guidebook 38, $46 \mathrm{p}$.

1988, Tertiary strata in Iowa, in Program abstracts, 100th session: Journal of the Iowa Academy of Science, v. 95, no.1, abstract 176. 
Table 1. Geologic logs of test holes and observation wells drilled in southwest Iowa, 1985-87

[Stratigraphic names and descriptions are those of the Iowa Department of Natural Resources; DDMMSS, degrees minutes seconds; U, shallow well at site; L, deep well at site; all well casing is 2-inch-diameter polyvinyl-chloride pipe]

\begin{tabular}{|c|c|c|c|c|c|c|c|}
\hline \multirow{2}{*}{$\begin{array}{c}\text { Southwest } \\
\text { Iowa study } \\
\text { identification } \\
\text { number } \\
\text { (fig. 1) }\end{array}$} & \multicolumn{2}{|c|}{$\begin{array}{c}\text { Geological } \\
\text { Survey Bureau } \\
\text { identification } \\
\text { number }\end{array}$} & \multicolumn{2}{|c|}{$\begin{array}{l}\text { Township- } \\
\text { range-section } \\
\text { identification } \\
\text { number }\end{array}$} & $\begin{array}{c}\text { Latitude-longitude } \\
\text { identification } \\
\text { number }\end{array}$ & $\begin{array}{l}\text { Land- } \\
\text { surface } \\
\text { altitude } \\
\text { (feet above } \\
\text { sea level) }\end{array}$ & County \\
\hline & $\mathbf{W}-2$ & & & 41-17ADCC & 403709-0953406 & 1,085 & Fremont \\
\hline $\begin{array}{c}\text { Stratigrap } \\
\text { unit }\end{array}$ & & & & cerval & Description & & \\
\hline \multicolumn{2}{|c|}{ Quaternary deposits } & $\begin{array}{r}0 \\
3 \\
7 \\
15 \\
20\end{array}$ & $\begin{array}{l}\text { to } \\
\text { to } \\
\text { to } \\
\text { to } \\
\text { to }\end{array}$ & $\begin{array}{r}3 \\
7 \\
15 \\
20 \\
30\end{array}$ & \multicolumn{3}{|c|}{$\begin{array}{l}\text { No sample } \\
\text { Silt, orange-brown, very argillaceous } \\
\text { Silt, pale yellow, slightly argillaceous } \\
\text { Silt, orange, very argillaceous } \\
\text { Silt, maroon-orange }\end{array}$} \\
\hline \multicolumn{2}{|c|}{ Pleistocene deposits } & $\begin{array}{l}30 \\
33 \\
33 \\
43 \\
45 \\
65 \\
73 \\
80\end{array}$ & $\begin{array}{l}\text { to } \\
\text { to } \\
\text { to } \\
\text { to } \\
\text { to } \\
\text { to } \\
\text { to } \\
\text { to }\end{array}$ & $\begin{array}{l}33 \\
33 \\
43 \\
45 \\
65 \\
73 \\
80 \\
94\end{array}$ & \multicolumn{3}{|c|}{$\begin{array}{l}\text { Till, orange, oxidized, leached } \\
\text { Till, orange, oxidized, leached } \\
\text { Till, orange-yellow, oxidized, leached } \\
\text { Sand, colorless and varicolored, coarse to fine } \\
\text { Till, yellow, oxidized, unleached } \\
\text { Till, orange-brown, oxidized, unleached } \\
\text { Till, light olive-gray, unoxidized, unleached } \\
\text { Sand, colorless and varicolored, coarse to fine, } \\
\text { subrounded, quartz; gravel, quartz, and } \\
\text { metamorphic rock }\end{array}$} \\
\hline SW2 & \multicolumn{2}{|c|}{ W-27554 } & \multicolumn{2}{|c|}{ 67-41-20CDDD } & 403600-0953427 & 1,135 & Fremont \\
\hline $\begin{array}{c}\text { Stratigrap } \\
\text { unit }\end{array}$ & & \multicolumn{3}{|c|}{$\begin{array}{l}\text { Depth interval } \\
\text { (feet) }\end{array}$} & Description & & \\
\hline \multicolumn{2}{|c|}{ Quaternary deposits } & $\begin{array}{r}0 \\
10 \\
15 \\
20 \\
26 \\
30 \\
50\end{array}$ & $\begin{array}{l}\text { to } \\
\text { to } \\
\text { to } \\
\text { to } \\
\text { to } \\
\text { to } \\
\text { to }\end{array}$ & $\begin{array}{l}10 \\
15 \\
20 \\
26 \\
30 \\
50 \\
70\end{array}$ & \multicolumn{3}{|c|}{$\begin{array}{l}\text { Silt, yellow, argillaceous } \\
\text { Silt, very light yellow, argillaceous } \\
\text { Silt, yellow-orange, argillaceous } \\
\text { Silt, gray-yellow, argillaceous } \\
\text { Silt, pale maroon, argillaceous } \\
\text { Silt, orange, argillaceous } \\
\text { Silt, light orange-gray, very argillaceous }\end{array}$} \\
\hline \multicolumn{2}{|c|}{ Pleistocene deposits } & $\begin{array}{l}70 \\
74 \\
108 \\
110 \\
122 \\
125\end{array}$ & $\begin{array}{l}\text { to } \\
\text { to } \\
\text { to } \\
\text { to }\end{array}$ & $\begin{array}{l}110 \\
122 \\
125 \\
131\end{array}$ & \multicolumn{3}{|c|}{$\begin{array}{l}\text { Till, orange, oxidized, leached } \\
\text { Sand, colorless, varicolored, medium to fine } \\
\text { and coarse, subrounded to subangular } \\
\text { Till, dark green-gray, unoxidized, unleached } \\
\text { Till, light olive-gray, unoxidized, unleached } \\
\text { Till, light yellow, oxidized, leached } \\
\text { Silt, very light yellow-orange, calcareous }\end{array}$} \\
\hline
\end{tabular}


Table 1. Geologic logs of test holes and observation wells drilled in southwest Iowa, 1985-87--Continued

\begin{tabular}{|c|c|c|c|c|c|c|c|}
\hline \multicolumn{2}{|c|}{$\begin{array}{l}\text { Stratigraphic } \\
\text { unit }\end{array}$} & \multicolumn{3}{|c|}{$\begin{array}{l}\text { Depth interval } \\
\text { (feet) }\end{array}$} & \multicolumn{3}{|l|}{ Description } \\
\hline \multicolumn{8}{|c|}{ SW2--Continued } \\
\hline \multirow{5}{*}{\multicolumn{2}{|c|}{$\begin{array}{l}\text { Pleistocene deposits-- } \\
\text { Continued }\end{array}$}} & 131 & to & 132 & \multicolumn{3}{|c|}{$\begin{array}{l}\text { Silt, very light yellow-orange, calcareous; } \\
\text { limestone, very light gray }\end{array}$} \\
\hline & & 132 & to & 140 & \multicolumn{3}{|c|}{$\begin{array}{l}\text { Silt, very light yellow-orange, calcareous, } \\
\text { argillaceous }\end{array}$} \\
\hline & & 140 & to & 155 & \multicolumn{3}{|c|}{$\begin{array}{l}\text { Silt, very light yellow-orange, calcareous, } \\
\text { argillaceous, trace sand }\end{array}$} \\
\hline & & 155 & to & 164 & \multirow{2}{*}{\multicolumn{3}{|c|}{$\begin{array}{l}\text { Till, light gray, unoxidized, unleached } \\
\text { Sand, colorless, varicolored, trace dark grains }\end{array}$}} \\
\hline & & 164 & to & 169 & & & \\
\hline \multirow{10}{*}{\multicolumn{2}{|c|}{$\begin{array}{l}\text { Pennsylvanian rocks, } \\
\text { undifferentiated }\end{array}$}} & 169 & to & 174 & \multicolumn{3}{|c|}{$\begin{array}{l}\text { Dolostone, very light yellow-gray to gray, silty, } \\
\text { sandy, calcareous, micaceous }\end{array}$} \\
\hline & & 174 & to & 176 & \multicolumn{3}{|c|}{$\begin{array}{l}\text { Shale, green-gray, lumpy, soft, micaceous, } \\
\text { calcareous }\end{array}$} \\
\hline & & 176 & to & 180 & \multirow{2}{*}{\multicolumn{3}{|c|}{$\begin{array}{l}\text { Siltstone, green-gray, argillaceous } \\
\text { Shale, gray, silty, calcareous, with micaceous } \\
\text { partings }\end{array}$}} \\
\hline & & 180 & to & 190 & & & \\
\hline & & 190 & to & 191 & \multirow{6}{*}{\multicolumn{3}{|c|}{$\begin{array}{l}\text { Limestone, gray, silt-grade, argillaceous } \\
\text { Shale, gray, with limestone nodules } \\
\text { Shale, very dark gray, blocky, carbonaceous } \\
\text { Shale, green, blocky, silty } \\
\text { Shale, gray, very light gray, lumpy } \\
\text { Shale, very light gray, very dark gray, lumpy, silty, } \\
\text { calcareous }\end{array}$}} \\
\hline & & 191 & & 192 & & & \\
\hline & & 192 & & 193 & & & \\
\hline & & 193 & & 197 & & & \\
\hline & & 197 & & 199 & & & \\
\hline & & 199 & & 201 & & & \\
\hline $\begin{array}{l}\text { Southwest } \\
\text { Iowa study } \\
\text { identification } \\
\text { number } \\
\text { (fig. 1) }\end{array}$ & \multicolumn{2}{|c|}{$\begin{array}{c}\text { Geological } \\
\text { Survey Bureau } \\
\text { identification } \\
\text { number }\end{array}$} & \multicolumn{2}{|c|}{$\begin{array}{l}\text { Township- } \\
\text { range-section } \\
\text { identification } \\
\text { number }\end{array}$} & \multicolumn{3}{|c|}{$\begin{array}{ccc}\begin{array}{c}\text { Latitude-longitude } \\
\text { identification }\end{array} & \begin{array}{c}\text { Land- } \\
\text { surface } \\
\text { number }\end{array} & \begin{array}{c}\text { altitude } \\
\text { (feet above }\end{array} \\
\text { sea level) } & \text { County } \\
\end{array}$} \\
\hline sW3 & \multicolumn{2}{|c|}{ W-27555 } & \multicolumn{2}{|c|}{ 67-41-30ABBB } & 409558-0953533 & 1,040 & Fremont \\
\hline \multicolumn{2}{|c|}{$\begin{array}{c}\text { Stratigraphic } \\
\text { unit }\end{array}$} & \multicolumn{3}{|c|}{$\begin{array}{c}\text { Depth interval } \\
\text { (feet) }\end{array}$} & Description & & \\
\hline \multirow{5}{*}{\multicolumn{2}{|c|}{ Quaternary deposits }} & 0 & to & 5 & \multirow{5}{*}{\multicolumn{3}{|c|}{$\begin{array}{l}\text { No sdmple } \\
\text { Silt, argillaceous, calcareous } \\
\text { Silt, light yellow, argillaceous } \\
\text { Silt, orange, argillaceous } \\
\text { Silt, pale maroon, argillaceous }\end{array}$}} \\
\hline & & 5 & to & 15 & & & \\
\hline & & 15 & to & 20 & & & \\
\hline & & 20 & to & 60 & & & \\
\hline & & 60 & to & 67 & & & \\
\hline \multirow{2}{*}{\multicolumn{2}{|c|}{$\begin{array}{l}\text { Cretaceous rocks } \\
\text { Dakota } \\
\text { Formation }\end{array}$}} & 67 & to & 75 & \multirow{2}{*}{\multicolumn{3}{|c|}{$\begin{array}{l}\text { Sand, colorless, orange, medium to fine and } \\
\text { coarse, subrounded to angular } \\
\text { Silt, orange-gray, argillaceous }\end{array}$}} \\
\hline & & 75 & to & 78 & & & \\
\hline \multirow{3}{*}{\multicolumn{2}{|c|}{$\begin{array}{l}\text { Pennsylvanian rocks, } \\
\text { undifferentiated }\end{array}$}} & 78 & to & 80 & \multirow{3}{*}{\multicolumn{3}{|c|}{$\begin{array}{l}\text { Shale, gray, slightly silty } \\
\text { Shale, gray, lumpy } \\
\text { Shale, gray, lumpy, slightly calcareous } \\
\text { Shale, gray, lumpy, slightly calcareous, with } \\
\text { limestone nodules }\end{array}$}} \\
\hline & & $\begin{array}{l}80 \\
90\end{array}$ & $\begin{array}{l}\text { to } \\
\text { to }\end{array}$ & $\begin{array}{l}90 \\
99\end{array}$ & & & \\
\hline & & 99 & & 101 & & & \\
\hline
\end{tabular}


Table 1. Geologic logs of test holes and observation wells drilled in southwest Iowa, 1985-87--Continued

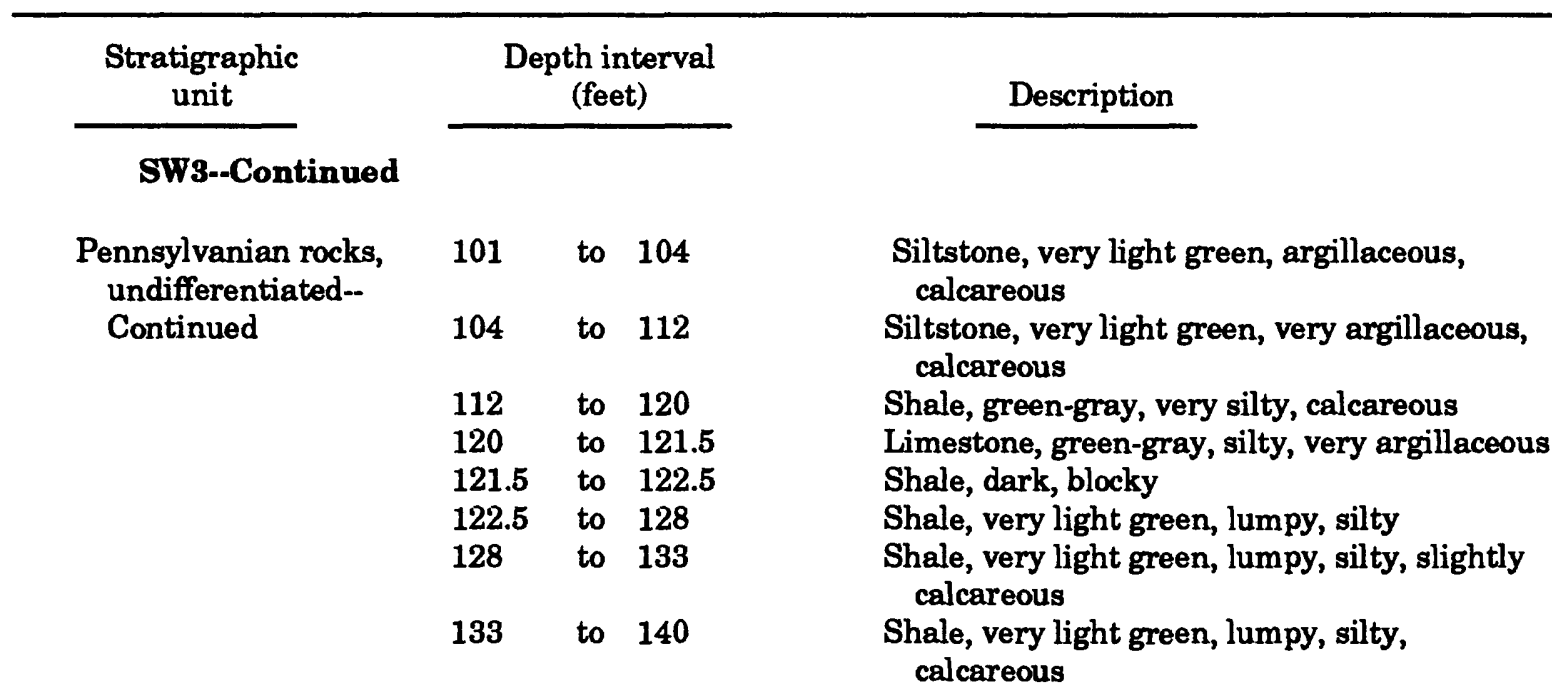

\begin{tabular}{cccccc}
\hline $\begin{array}{c}\text { Southwest } \\
\text { lowa study } \\
\text { identification } \\
\text { number } \\
\text { (fig. 1) }\end{array}$ & $\begin{array}{c}\text { Geological } \\
\text { Survey Bureau } \\
\text { identification } \\
\text { number }\end{array}$ & $\begin{array}{c}\text { Township- } \\
\text { range-section } \\
\text { identification } \\
\text { number }\end{array}$ & $\begin{array}{c}\text { Latitude-longitude } \\
\text { identification } \\
\text { number }\end{array}$ & $\begin{array}{c}\text { Land- } \\
\text { surface } \\
\text { altitude } \\
\text { (feet above } \\
\text { sea level) }\end{array}$ & County \\
\hline SW4 & W-27556 & $\mathbf{6 7 - 4 1 - 2 0 C D D D}$ & $\mathbf{4 0 3 6 0 0 - 0 9 5 3 4 2 7}$ & $\mathbf{1 , 1 3 8}$ & Fremont
\end{tabular}

Note: This is a rock core reposited at the Iowa Department of Natural Resources, Geological Survey Bureau.

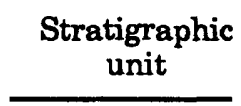

Pleistocene deposits

Tertiary deposits

Pennsylvanian rocks

$\begin{array}{rrr} & & \\ 0 & \text { to } & 55 \\ 55 & \text { to } & 75 \\ 75 & \text { to } & 80 \\ 80 & \text { to } & 109 \\ 109 & \text { to } & 111 \\ 111 & \text { to } & 128\end{array}$

$$
128
$$

$\begin{array}{lll}135.5 & \text { to } & 151.5 \\ 151.5 & \text { to } & 155 \\ 155 & \text { to } & 166 \\ 166 & \text { to } & 170 \\ 170 & \text { to } & 174\end{array}$

\section{Depth interval (feet)}

174 to 1,116

\section{Description}

\section{Peorian loess}

Loveland loess

Till, oxidized, leached

Sand and gravel

Till, oxidized, unleached

Till, unoxidized, unleached

Clay, medium brown-gray, light medium brown-gray, very silty, slightly sandy; sandstone, very fine; siltstone

Clay, silty

Siltstone, clay

Silt

Silt

Sand

Description available from:

Iowa Department of Natural Resources,

Geological Survey Bureau

123 N. Capitol St.

Iowa City, IA 52242 
Table 1. Geologic logs of test holes and observation wells drilled in southwest Iowa, 1985-87--Continued

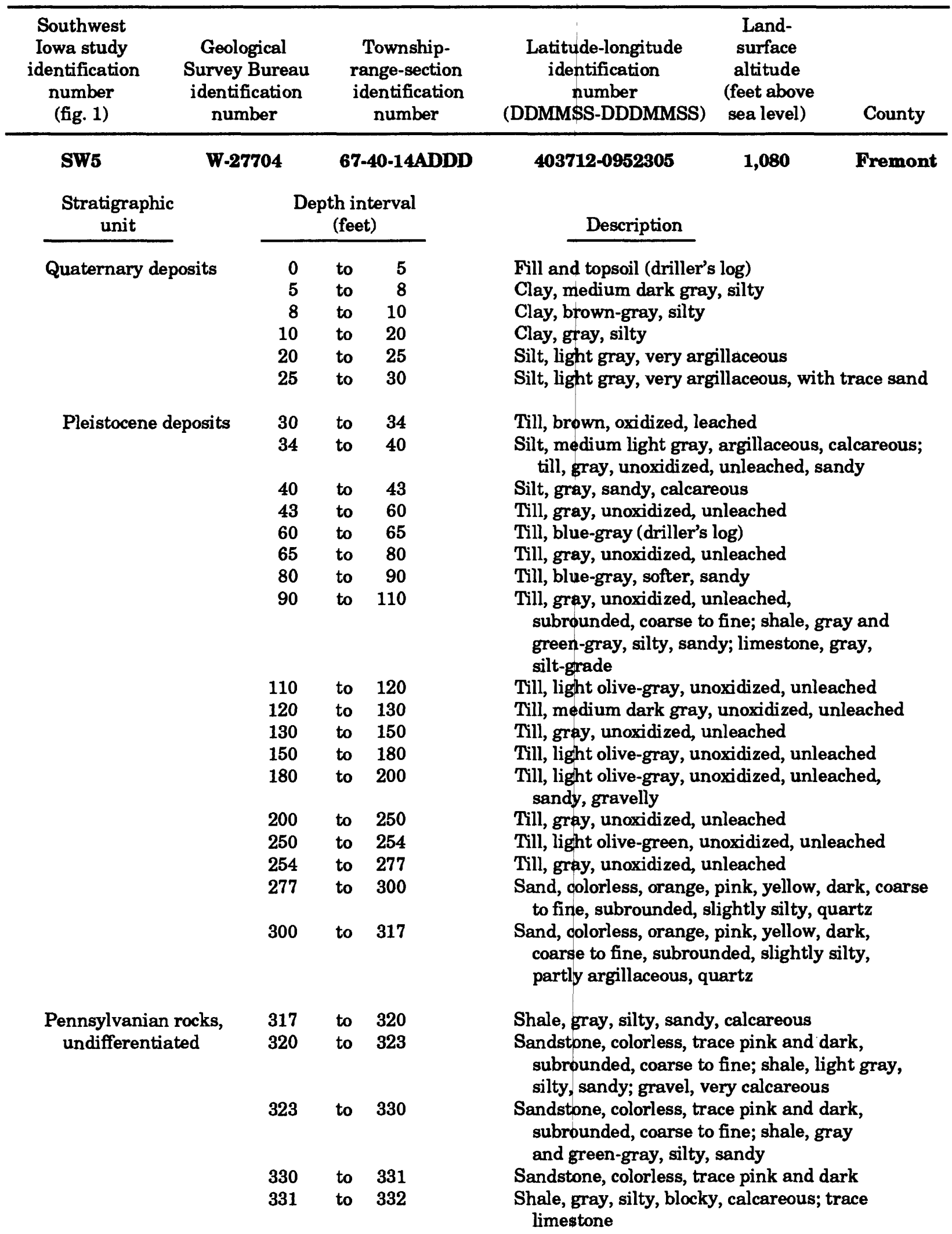


Table 1. Geologic logs of test holes and observation wells drilled in southwest Iowa, 1985-87--Continued

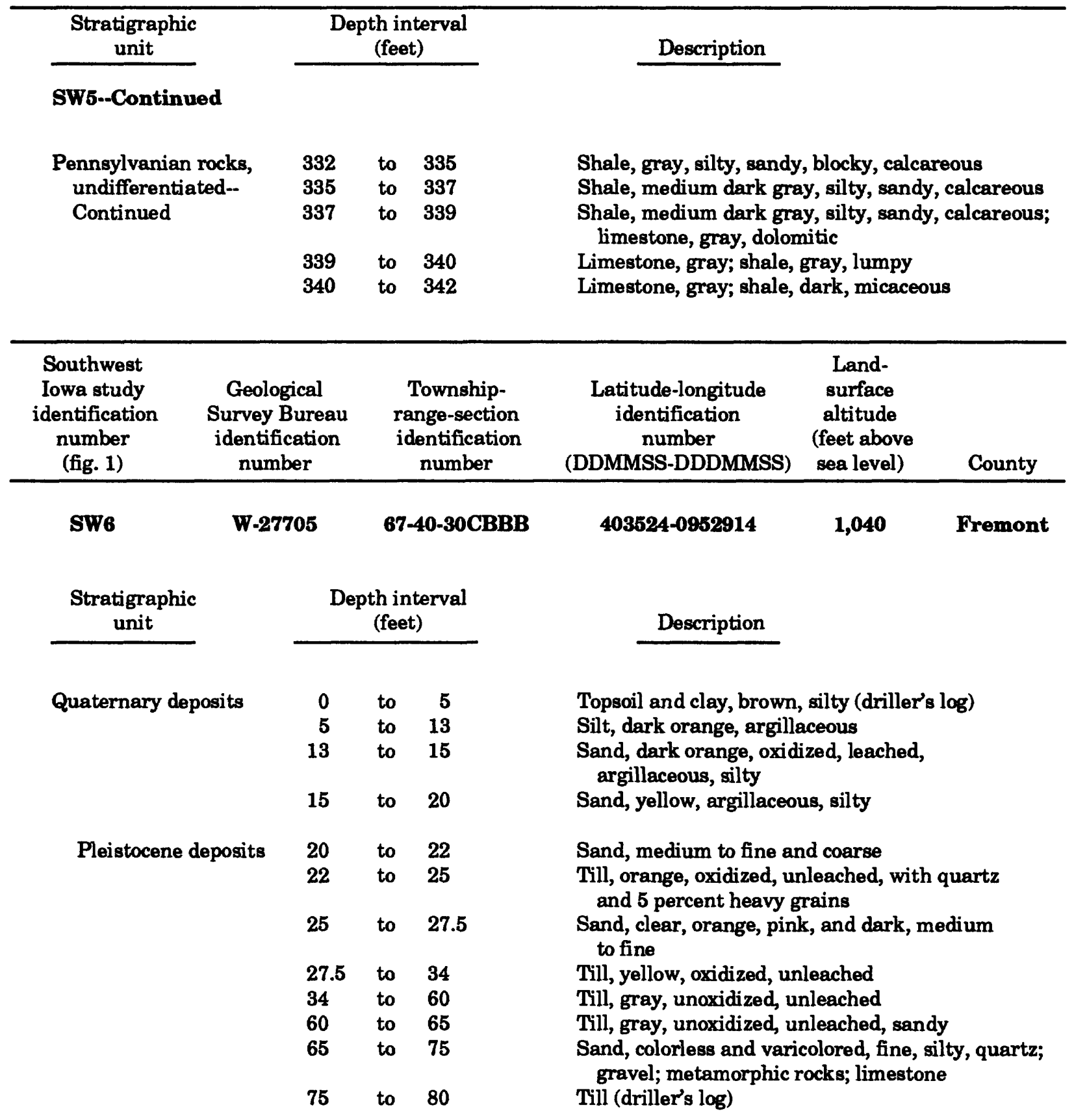


Table 1. Geologic logs of test holes and observation wells drilled in southwest Iowa, 1985-87-Continued

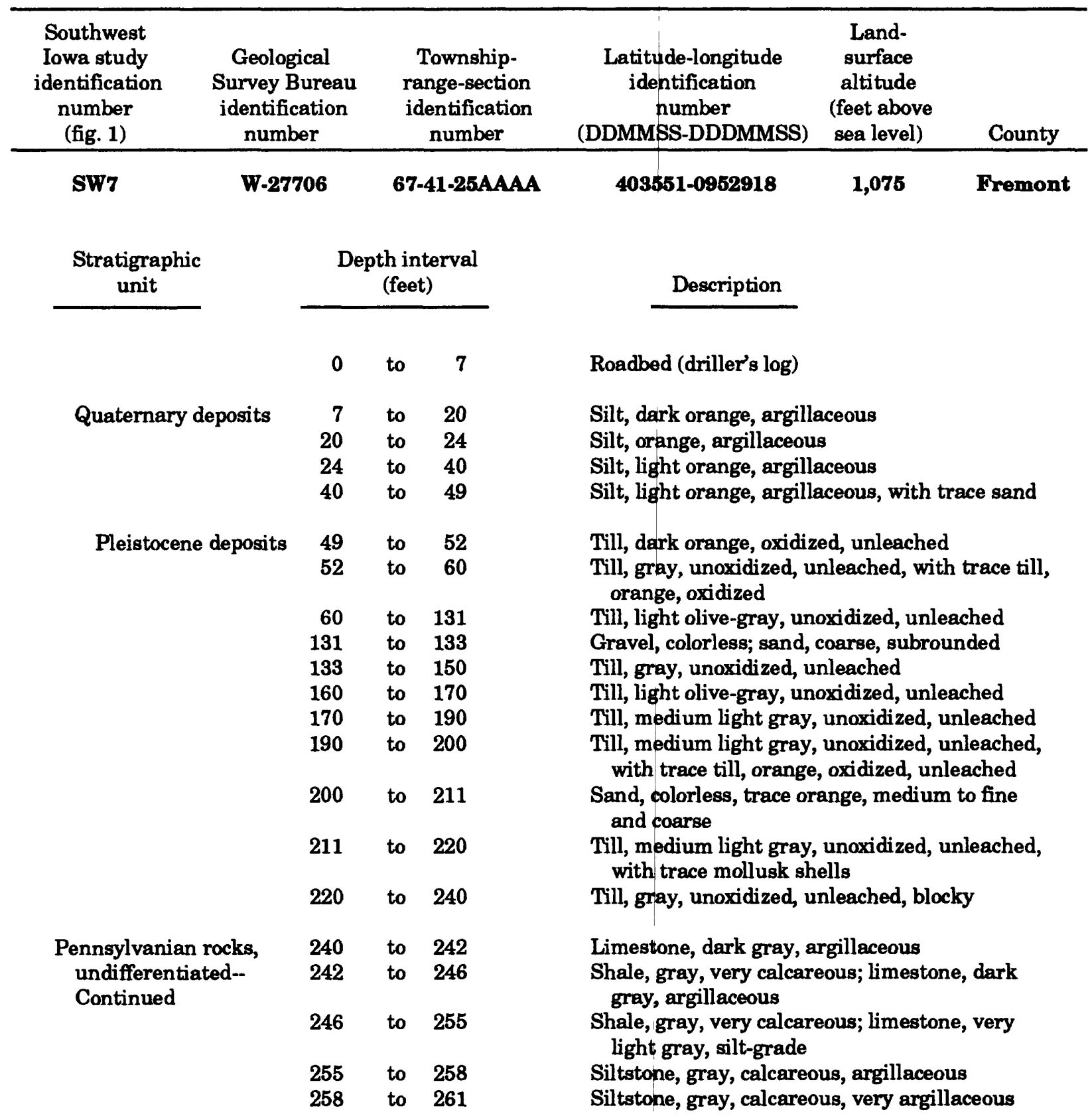


Table 1. Geologic logs of test holes and observation wells drilled in southwest lowa, 1985-87--Continued

\begin{tabular}{|c|c|c|c|c|c|c|c|}
\hline \multirow{2}{*}{$\begin{array}{c}\begin{array}{c}\text { Southwest } \\
\text { Iowa study } \\
\text { identification } \\
\text { number } \\
\text { (fig. 1) }\end{array} \\
\text { SW8 }\end{array}$} & \multicolumn{2}{|c|}{$\begin{array}{l}\text { Geological } \\
\text { Survey Bureau } \\
\text { identification } \\
\text { number }\end{array}$} & \multicolumn{2}{|c|}{$\begin{array}{l}\text { Township- } \\
\text { range-section } \\
\text { identification } \\
\text { number }\end{array}$} & \multirow{2}{*}{$\begin{array}{c}\begin{array}{c}\text { Latitude-longitude } \\
\text { identification } \\
\text { number }\end{array} \\
\text { (DDMMSS-DDDMMSS) } \\
\mathbf{4 0 3 6 0 2 - 0 9 5 2 6 5 9}\end{array}$} & $\begin{array}{l}\text { Land- } \\
\text { surface } \\
\text { altitude } \\
\text { (feet above } \\
\text { sea level) } \\
\end{array}$ & \multirow{2}{*}{$\begin{array}{l}\text { County } \\
\text { Fremont }\end{array}$} \\
\hline & $\mathbf{W}-2$ & & & 40-21CCAC & & 1,065 & \\
\hline \multirow{2}{*}{\multicolumn{2}{|c|}{$\begin{array}{l}\text { Stratigraphic } \\
\text { unit }\end{array}$}} & \multicolumn{3}{|c|}{$\begin{array}{l}\text { Depth interval } \\
\quad \text { (feet) }\end{array}$} & Description & & \\
\hline & & 0 & to & 7 & Roadbed (driller's log) & & \\
\hline \multicolumn{2}{|c|}{ Quaternary deposits } & $\begin{array}{r}7 \\
9 \\
14 \\
17 \\
20 \\
35 \\
37 \\
40 \\
50 \\
57 \\
60\end{array}$ & $\begin{array}{l}\text { to } \\
\text { to } \\
\text { to } \\
\text { to } \\
\text { to } \\
\text { to } \\
\text { to } \\
\text { to } \\
\text { to } \\
\text { to } \\
\text { to }\end{array}$ & $\begin{array}{r}9 \\
14 \\
17 \\
20 \\
35 \\
37 \\
40 \\
50 \\
57 \\
60 \\
63\end{array}$ & \multicolumn{3}{|c|}{$\begin{array}{l}\text { Clay, medium dark gray, slightly silty, } \\
\text { Clay, brown, with trace sand } \\
\text { Clay, medium light gray, slightly silty } \\
\text { Clay, gray, silty } \\
\text { Clay, gray, slightly silty } \\
\text { Clay, brown-gray } \\
\text { Clay, yellow-gray clay } \\
\text { Clay, medium light gray, slightly silty } \\
\text { Clay, yellow-gray } \\
\text { Clay, brown, silty } \\
\text { Sand, colorless and varicolored; gravel, } \\
\text { varicolored }\end{array}$} \\
\hline \multirow{16}{*}{\multicolumn{2}{|c|}{ Pleistocene deposits }} & 63 & to & 65 & \multirow{6}{*}{\multicolumn{3}{|c|}{$\begin{array}{l}\text { Till, gray, unoxidized, unleached } \\
\text { Till, light olive-gray, unoxidized, unleached } \\
\text { Till, gray, unoxidized, unleached } \\
\text { Till, light olive-gray, unoxidized, unleached, sandy } \\
\text { Gravel, varicolored; sand, very dirty, subrounded } \\
\text { Till, light olive-gray, unoxidized, unleached, sandy; } \\
\text { with till, yellow, oxidized, leached }\end{array}$}} \\
\hline & & 65 & to & 71 & & & \\
\hline & & 71 & to & 75 & & & \\
\hline & & 75 & to & 130 & & & \\
\hline & & 130 & to & 140 & & & \\
\hline & & 140 & to & 160 & & & \\
\hline & & 160 & to & 180 & \multirow{4}{*}{\multicolumn{3}{|c|}{$\begin{array}{l}\text { Till, brown-gray, unoxidized, unleached } \\
\text { Till, light olive-gray, unoxidized, unleached } \\
\text { Till, light olive-gray, unoxidized, unleached; gravel } \\
\text { Gravel, varicolored; sand, medium; with till matrix, } \\
\text { light olive-gray, unoxidized, unleached }\end{array}$}} \\
\hline & & 180 & to & 240 & & & \\
\hline & & 240 & to & 246 & & & \\
\hline & & 246 & to & 255 & & & \\
\hline & & 255 & to & 260 & \multicolumn{3}{|c|}{ Till, brown-gray, unoxidized, unleached } \\
\hline & & 260 & to & 288 & \multicolumn{3}{|c|}{ Till, light gray, unoxidized, unleached } \\
\hline & & 288 & to & 300 & \multicolumn{3}{|c|}{ Till, light olive-gray, unoxidized, unleached } \\
\hline & & 300 & to & 316 & \multicolumn{3}{|c|}{ Till, light brown-gray, unoxidized, unleached } \\
\hline & & 316 & to & 318 & \multicolumn{3}{|c|}{$\begin{array}{l}\text { Till, light brown-gray, unoxidized, unleached, } \\
\text { very sandy }\end{array}$} \\
\hline & & $\begin{array}{l}318 \\
344\end{array}$ & $\begin{array}{l}\text { to } \\
\text { to }\end{array}$ & $\begin{array}{l}344 \\
350\end{array}$ & \multicolumn{3}{|c|}{$\begin{array}{l}\text { Till, light olive-gray, unoxidized, unleached } \\
\text { Till, light olive-gray, unoxidized, unleached; } \\
\text { limestone, very light gray, silt-grade }\end{array}$} \\
\hline
\end{tabular}

Pennsylvanian rocks, 
Table 1. Geologic logs of test holes and observation wells drilled in southwest Iowa, 1985-87--Continued

\begin{tabular}{cccccc}
\hline $\begin{array}{c}\text { Southwest } \\
\text { Iowa study } \\
\text { identification } \\
\text { number } \\
\text { (fig. 1) }\end{array}$ & $\begin{array}{c}\text { Geological } \\
\text { Survey Bureau } \\
\text { identification } \\
\text { number }\end{array}$ & $\begin{array}{c}\text { Township- } \\
\text { range-section } \\
\text { identification } \\
\text { number }\end{array}$ & $\begin{array}{c}\text { Latitude-longitude } \\
\text { identification } \\
\text { number }\end{array}$ & $\begin{array}{c}\text { Land- } \\
\text { surface } \\
\text { altitude } \\
\text { (feet above } \\
\text { sea level) }\end{array}$ & County \\
\hline SW9 & W-27708 & $\mathbf{6 8 - 4 1 - 1 1 C D C C}$ & $\mathbf{4 0 4 2 5 6 - 0 9 5 3 1 0 4}$ & $\mathbf{9 4 5}$ & Fremont
\end{tabular}
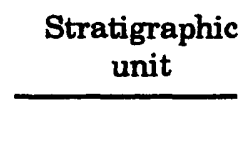

Quaternary deposits

\begin{tabular}{|c|c|c|c|}
\hline \multirow[t]{2}{*}{$\begin{array}{c}\text { Stratigraphic } \\
\text { unit }\end{array}$} & \multicolumn{3}{|c|}{$\begin{array}{l}\text { Depth interval } \\
\text { (feet) }\end{array}$} \\
\hline & 0 & to & 3 \\
\hline \multirow[t]{9}{*}{ Quaternary deposits } & 3 & to & 5 \\
\hline & 5 & to & 20 \\
\hline & 20 & to & 23 \\
\hline & 23 & to & 25 \\
\hline & 25 & to & 28 \\
\hline & 28 & to & 35 \\
\hline & 35 & to & 40 \\
\hline & 40 & to & 51 \\
\hline & 51 & to & 60 \\
\hline \multirow[t]{7}{*}{ Pleistocene deposits } & 60 & to & 80 \\
\hline & & & \\
\hline & 115 & to & 138 \\
\hline & 138 & to & 160 \\
\hline & 160 & to & 170 \\
\hline & 170 & to & 180 \\
\hline & 180 & to & 202 \\
\hline
\end{tabular}

$\begin{array}{cll}\begin{array}{c}\text { Pennsylvanian rocks, } \\ \text { undifferentiated }\end{array} & 202 & \text { to } 208 \\ & 208 & \text { to } 211 \\ & 211 & \text { to } 211.5 \\ & 211.5 & \text { to } 214 \\ & 214 & \text { to } 215\end{array}$


Table 1. Geologic logs of test holes and observation wells drilled in southwest Iowa, 1985-87-Continued

\begin{tabular}{|c|c|c|c|c|c|c|c|}
\hline \multirow{2}{*}{$\begin{array}{c}\text { Southwest } \\
\text { Iowa study } \\
\text { identification } \\
\text { number } \\
\text { (fig. 1) }\end{array}$} & \multicolumn{2}{|c|}{$\begin{array}{c}\text { Geological } \\
\text { Survey Bureau } \\
\text { identification } \\
\text { number }\end{array}$} & \multicolumn{2}{|c|}{$\begin{array}{l}\text { Township- } \\
\text { range-section } \\
\text { identification } \\
\text { number }\end{array}$} & $\begin{array}{c}\text { Latitude-longitude } \\
\text { identification } \\
\text { number } \\
\text { (DDMMSS-DDDMMSS) }\end{array}$ & \multirow{2}{*}{$\begin{array}{l}\text { Land- } \\
\text { surface } \\
\text { altitude } \\
\text { (feet above } \\
\text { sea level) } \\
\mathbf{9 3 5}\end{array}$} & \multirow{2}{*}{$\begin{array}{c}\text { County } \\
\text { Fremont }\end{array}$} \\
\hline & $\mathbf{W}-2$ & & & 42-12ADAC & 404324-0953554 & & \\
\hline $\begin{array}{c}\text { Stratigrap } \\
\text { unit }\end{array}$ & & & & $\begin{array}{l}\text { terval } \\
\text { t) }\end{array}$ & Description & & \\
\hline \multicolumn{2}{|c|}{ Quaternary deposits } & $\begin{array}{r}0 \\
5 \\
12 \\
20 \\
27 \\
35 \\
36 \\
37\end{array}$ & $\begin{array}{l}\text { to } \\
\text { to } \\
\text { to } \\
\text { to } \\
\text { to } \\
\text { to } \\
\text { to } \\
\text { to }\end{array}$ & $\begin{array}{r}5 \\
12 \\
20 \\
27 \\
35 \\
36 \\
37 \\
42\end{array}$ & \multicolumn{3}{|c|}{$\begin{array}{l}\text { Roadbed and topsoil (driller's log) } \\
\text { Silt, yellow-orange, very argillaceous } \\
\text { Clay, orange, silty } \\
\text { Clay, very light yellow-orange, silty, calcareous } \\
\text { Clay, gray, silty, calcareous } \\
\text { Clay, medium dark brown, sandy } \\
\text { Clay, gray, silty, calcareous } \\
\text { Sand, colorless to varicolored, coarse to fine; } \\
\text { gravel, subrounded }\end{array}$} \\
\hline \multirow{3}{*}{\multicolumn{2}{|c|}{ Pleistocene deposits }} & 42 & to & 43 & \multirow{3}{*}{\multicolumn{3}{|c|}{$\begin{array}{l}\text { Till, gray, unoxidized, unleached, weakly } \\
\text { calcareous } \\
\text { Till, gray, unoxidized, unleached } \\
\text { Till, gray, unoxidized, unleached, silty } \\
\text { Till, light olive-gray, unoxidized, unleached } \\
\text { Sand, colorless and varicolored, coarse to fine; } \\
\text { gravel, subrounded, calcareous, argillaceous, } \\
\text { silty } \\
\text { Till, gray, unoxidized, unleached } \\
\text { Sand, colorless, orange, pink, coarse to fine, } \\
\text { subrounded, quartz; gravel, very clean; quartz; } \\
\text { igneous, metamorphic, and carbonate rocks }\end{array}$}} \\
\hline & & $\begin{array}{l}43 \\
47 \\
60 \\
88\end{array}$ & $\begin{array}{l}\text { to } \\
\text { to } \\
\text { to } \\
\text { to }\end{array}$ & $\begin{array}{l}47 \\
60 \\
88 \\
90\end{array}$ & & & \\
\hline & & $\begin{array}{r}90 \\
151\end{array}$ & $\begin{array}{l}\text { to } \\
\text { to }\end{array}$ & $\begin{array}{l}151 \\
164\end{array}$ & & & \\
\hline \multirow{7}{*}{\multicolumn{2}{|c|}{$\begin{array}{l}\text { Pennsylvanian rocks, } \\
\text { undifferentiated }\end{array}$}} & 164 & to & 171 & \multirow{4}{*}{\multicolumn{3}{|c|}{$\begin{array}{l}\text { Shale, green, lumpy, calcareous, with calcareous } \\
\text { nodules } \\
\text { Dolostone, very light gray, silt-grade, crystalline; } \\
\text { shale, green, lumpy, calcareous, sandy } \\
\text { Shale, gray, silty, calcareous; dolostone, very light } \\
\text { gray, silt-grade, crystalline dolostone } \\
\text { Shale, gray; dolostone, gray, silt-grade, }\end{array}$}} \\
\hline & & 171 & to & 171.5 & & & \\
\hline & & 171.5 & to & 174 & & & \\
\hline & & 174 & to & 176 & & & \\
\hline & & 176 & to & 180 & \multirow{3}{*}{\multicolumn{3}{|c|}{$\begin{array}{l}\text { calcareous, very argillaceous } \\
\text { Shale, green-gray, calcareous, with limestone } \\
\text { nodules } \\
\text { Shale, green-gray, silty, calcareous } \\
\text { Shale, gray, silty, calcareous } \\
\text { Shale, green-gray, silty, calcareous } \\
\text { Shale, green-gray, silty, calcareous; limestone, } \\
\text { dark green, silt-grade, argillaceous } \\
\text { Shale, gray, silty, calcareous }\end{array}$}} \\
\hline & & $\begin{array}{l}180 \\
182 \\
184 \\
186\end{array}$ & $\begin{array}{l}\text { to } \\
\text { to } \\
\text { to } \\
\text { to }\end{array}$ & $\begin{array}{l}182 \\
184 \\
186 \\
189\end{array}$ & & & \\
\hline & & 189 & to & 191 & & & \\
\hline
\end{tabular}

Note: Well flows at the land surface from 300 to 500 gallons per minute from 150 to 164 feet below land surface after hole was completed. 
Table 1. Geologic logs of test holes and observation wells drilled in southwest Iowa, 1985-87--Continued

\begin{tabular}{|c|c|c|c|c|c|c|c|}
\hline $\begin{array}{l}\text { Southwest } \\
\text { Iowa study } \\
\text { identification } \\
\text { number } \\
\text { (fig. 1) }\end{array}$ & \multicolumn{2}{|c|}{$\begin{array}{c}\text { Geological } \\
\text { Survey Bureau } \\
\text { identification } \\
\text { number }\end{array}$} & \multicolumn{2}{|c|}{$\begin{array}{l}\text { Township- } \\
\text { range-section } \\
\text { identification } \\
\text { number }\end{array}$} & $\begin{array}{c}\text { Latitude-longitude } \\
\text { identification } \\
\text { number } \\
\text { (DDMMSS-DDDMMSS) }\end{array}$ & $\begin{array}{l}\text { Land- } \\
\text { surface } \\
\text { altitude } \\
\text { (feet above } \\
\text { sea level) }\end{array}$ & County \\
\hline SW11 & \multicolumn{2}{|c|}{ W-27710 } & \multicolumn{2}{|c|}{ 70-41-32ABBB } & 404906-0953504 & 948 & Fremont \\
\hline $\begin{array}{c}\text { Stratigra } \\
\text { unit }\end{array}$ & \multicolumn{4}{|c|}{$\begin{array}{l}\text { Depth interval } \\
\text { (feet) }\end{array}$} & Description & & \\
\hline \multirow{6}{*}{\multicolumn{2}{|c|}{ Quaternary deposits }} & 0 & to & 8 & \multirow{6}{*}{\multicolumn{3}{|c|}{$\begin{array}{l}\text { Roadbed and topsoil (driller's log) } \\
\text { Clay, dark gray, silty } \\
\text { Silt, yellow and gray, very argillaceous } \\
\text { Silt, orange, very argillaceous } \\
\text { Silt, yellow-orange; sand, varicolored, } \\
\text { subangular to subrounded } \\
\text { Sand, quartz; gravel, colorless and varicolored, } \\
\text { subrounded, coarse, igneous and } \\
\text { metamorphic rocks }\end{array}$}} \\
\hline & & 8 & to & 10 & & & \\
\hline & & 10 & to & 15 & & & \\
\hline & & 15 & to & 17 & & & \\
\hline & & 17 & to & 20 & & & \\
\hline & & 20 & to & 50 & & & \\
\hline \multirow{6}{*}{\multicolumn{2}{|c|}{ Pleistocene deposits }} & 50 & to & 110 & \multirow{3}{*}{\multicolumn{3}{|c|}{$\begin{array}{l}\text { Till, light olive-gray, unoxidized, unleached } \\
\text { Sand, colorless and varicolored, coarse to fine, } \\
\text { quartz, with } 5 \text { percent dark, heavy grains; } \\
\text { gravel, metamorphic and granite rocks } \\
\text { Sand, very clear, colorless, yellow, pink, and } \\
\text { dark grains, medium to coarse and fine }\end{array}$}} \\
\hline & & 110 & to & 140 & & & \\
\hline & & 140 & to & 160 & & & \\
\hline & & 160 & to & 180 & \multicolumn{3}{|c|}{$\begin{array}{l}\text { Sand, very clear, colorless, yellow, pink, and } \\
\text { dark grains, medium to coarse and fine; } \\
\text { gravel, varicolored, very clean }\end{array}$} \\
\hline & & 180 & to & 200 & \multicolumn{3}{|c|}{$\begin{array}{l}\text { Sand, very clear, colorless, yellow, pink, and dark } \\
\text { grains, medium to coarse and fine, slightly } \\
\text { silty; gravel, varicolored, very clean }\end{array}$} \\
\hline & & 200 & to & 210 & \multicolumn{3}{|c|}{$\begin{array}{l}\text { Gravel, varicolored, subrounded to angular } \\
\text { igneous and metamorphic rocks }\end{array}$} \\
\hline \multicolumn{2}{|c|}{$\begin{array}{l}\text { Pennsylvanian rocks, } \\
\text { undifferentiated }\end{array}$} & 210 & to & 215 & \multicolumn{3}{|c|}{$\begin{array}{l}\text { Dolostone, gray, calcareous, argillaceous; } \\
\text { grading to dolostone, very light gray, non- } \\
\text { argillaceous, silt-grade }\end{array}$} \\
\hline
\end{tabular}


Table 1. Geologic logs of test holes and observation wells drilled in southwest Iowa, 1985-87--Continued

\begin{tabular}{|c|c|c|c|c|c|c|c|}
\hline \multirow{2}{*}{$\begin{array}{c}\begin{array}{c}\text { Southwest } \\
\text { Iowa study } \\
\text { identification } \\
\text { number } \\
\text { (fig. 1) }\end{array} \\
\text { SW12 }\end{array}$} & \multicolumn{2}{|c|}{$\begin{array}{c}\text { Geological } \\
\text { Survey Bureau } \\
\text { identification } \\
\text { number }\end{array}$} & \multicolumn{2}{|c|}{$\begin{array}{l}\text { Township- } \\
\text { range-section } \\
\text { identification } \\
\text { number }\end{array}$} & $\begin{array}{c}\text { Latitude-longitude } \\
\text { identification } \\
\text { number } \\
\text { (DDMMSS-DDDMMSS) }\end{array}$ & \multirow{2}{*}{$\begin{array}{c}\begin{array}{c}\text { Land- } \\
\text { surface } \\
\text { altitude } \\
\text { (feet above } \\
\text { sea level) }\end{array} \\
976\end{array}$} & \multirow{2}{*}{$\frac{\text { County }}{\text { Fremont }}$} \\
\hline & $\mathbf{W}-2$ & & & 41-09DDDD & 405736-0953323 & & \\
\hline \multirow{2}{*}{\multicolumn{2}{|c|}{$\begin{array}{c}\text { Stratigraphic } \\
\text { unit }\end{array}$}} & \multicolumn{3}{|c|}{$\begin{array}{l}\text { Depth interval } \\
\text { (feet) }\end{array}$} & Description & & \\
\hline & & 0 & to & 8 & Roadbed and fill (driller' & s log) & \\
\hline \multirow{4}{*}{\multicolumn{2}{|c|}{ Quaternary deposits }} & 8 & to & 15 & Clay, brown, silty & & \\
\hline & & 15 & to & 18 & Clay, brown-gray, silty & & \\
\hline & & 18 & to & 25 & $\begin{array}{l}\text { Clay, gray, sandy; sand, } \\
\text { fine; gravel }\end{array}$ & varicolored, c & arse to \\
\hline & & 25 & to & 34 & $\begin{array}{l}\text { Sand, colorless and varic } \\
\text { gravel, varicolored, subr }\end{array}$ & $\begin{array}{l}\text { colored, coars } \\
\text { ounded, silty }\end{array}$ & to fine; \\
\hline \multirow{3}{*}{\multicolumn{2}{|c|}{ Pleistocene deposits }} & 34 & to & 180 & Till, light olive-gray, uno & xidized, unle & hed \\
\hline & & 180 & to & 211 & Till, gray, unoxidized, ur & aleached & \\
\hline & & 211 & to & 223 & $\begin{array}{l}\text { Gravel, varicolored, subr } \\
\text { igneous, metamorphic } \\
\text { sand, coarse, quartz, }\end{array}$ & $\begin{array}{l}\text { rounded to an } \\
\text { rocks, and dc } \\
\text { vith gray, till }\end{array}$ & $\begin{array}{l}\text { lar; } \\
\text { stone; } \\
\text { ke matrix }\end{array}$ \\
\hline \multirow{6}{*}{\multicolumn{2}{|c|}{$\begin{array}{l}\text { Pennsylvanian rocks, } \\
\text { undifferentiated }\end{array}$}} & 223 & to & 227 & $\begin{array}{l}\text { Limestone, very light gr } \\
\text { argillaceous }\end{array}$ & ay, silty, silt- & ade, \\
\hline & & 227 & to & 231 & $\begin{array}{l}\text { Limestone, very light gr } \\
\text { argillaceous; shale, gre }\end{array}$ & $\begin{array}{l}\text { ay, silty, silt- } \\
\text { ay; sand }\end{array}$ & ade, \\
\hline & & 231 & to & 244 & $\begin{array}{l}\text { Limestone, very light gr } \\
\text { argillaceous; shale, gr }\end{array}$ & $\begin{array}{l}\text { ay, silty, silt- } \\
\text { ay }\end{array}$ & ade, \\
\hline & & 244 & to & 249 & $\begin{array}{l}\text { Shale, very dark gray, bl } \\
\text { light gray, silty, silt-gr }\end{array}$ & $\begin{array}{l}\text { locky; limesto } \\
\text { cade, argillace }\end{array}$ & $\begin{array}{l}\text {, very } \\
\text { us }\end{array}$ \\
\hline & & 249 & to & 251 & Shale, green-gray, calcar & reous & \\
\hline & & 251 & to & 256 & Shale, dark gray, green- & gray, calcarec & \\
\hline
\end{tabular}

\begin{tabular}{|c|c|c|c|c|c|c|c|}
\hline $\begin{array}{l}\text { Southwest } \\
\text { Iowa study } \\
\text { identification } \\
\text { number } \\
\text { (fig. 1) }\end{array}$ & \multicolumn{2}{|c|}{$\begin{array}{c}\text { Geological } \\
\text { Survey Bureau } \\
\text { identification } \\
\text { number }\end{array}$} & \multicolumn{2}{|c|}{$\begin{array}{l}\text { Township- } \\
\text { range-section } \\
\text { identification } \\
\text { number }\end{array}$} & $\begin{array}{c}\text { Latitude-longitude } \\
\text { identification } \\
\text { number } \\
\text { (DDMMSS-DDDMMSS) }\end{array}$ & $\begin{array}{l}\text { Land- } \\
\text { surface } \\
\text { altitude } \\
\text { (feet above } \\
\text { sea level) }\end{array}$ & County \\
\hline SW13 & \multicolumn{2}{|c|}{ W-27712 } & \multicolumn{2}{|c|}{ 73-41-19ACAA } & $410645-0953556$ & 1,115 & Mills \\
\hline $\begin{array}{c}\text { Stratigra } \\
\text { unit }\end{array}$ & & \multicolumn{3}{|c|}{$\begin{array}{l}\text { Depth interval } \\
\text { (feet) }\end{array}$} & Description & & \\
\hline \multicolumn{2}{|c|}{ Quaternary deposits } & $\begin{array}{r}0 \\
5 \\
10 \\
20\end{array}$ & $\begin{array}{l}\text { to } \\
\text { to } \\
\text { to } \\
\text { to }\end{array}$ & $\begin{array}{r}5 \\
10 \\
20 \\
30\end{array}$ & \multicolumn{2}{|c|}{$\begin{array}{l}\text { Roadbed and topsoil (driller's log) } \\
\text { Silt, yellow-brown, argillaceous } \\
\text { Silt, gray-orange, argillaceous } \\
\text { Silt, yellow, argillaceous }\end{array}$} & \\
\hline Pleistocer & eposits & 30 & to & 34 & \multicolumn{3}{|c|}{ Till, oxidized, leached, with sparse sand } \\
\hline
\end{tabular}


Table 1. Geologic logs of test holes and observation wells drilled in southwest Iowa, 1985-87--Continued

\begin{tabular}{|c|c|c|c|c|c|c|c|}
\hline \multicolumn{2}{|l|}{$\begin{array}{c}\text { Stratigraphic } \\
\text { unit }\end{array}$} & \multicolumn{3}{|c|}{$\begin{array}{l}\text { Depth interval } \\
\text { (feet) }\end{array}$} & \multicolumn{3}{|l|}{ Description } \\
\hline \multicolumn{8}{|c|}{ SW13--Continued } \\
\hline \multirow{8}{*}{\multicolumn{2}{|c|}{$\begin{array}{l}\text { Pleistocene deposits-- } \\
\text { Continued }\end{array}$}} & 34 & & 40 & \multicolumn{3}{|c|}{$\begin{array}{l}\text { Till, yellow-orange, oxidized, unleached, weakly } \\
\text { calcareous }\end{array}$} \\
\hline & & 40 & & 57 & \multirow{2}{*}{\multicolumn{3}{|c|}{$\begin{array}{l}\text { Till, yellow-orange, oxidized, unleached } \\
\text { Till, dark orange and gray, partly unoxidized, } \\
\text { unleached }\end{array}$}} \\
\hline & & 57 & & 60 & & & \\
\hline & & 60 & & 120 & \multirow{2}{*}{\multicolumn{3}{|c|}{$\begin{array}{l}\text { Till, light olive-gray, unoxidized, unleached } \\
\text { Till, light olive-gray, unoxidized, unleached, } \\
\text { gravelly }\end{array}$}} \\
\hline & & 120 & & 160 & & & \\
\hline & & 160 & & 170 & \multirow{3}{*}{\multicolumn{3}{|c|}{$\begin{array}{l}\text { Till, brown-gray, unoxidized, unleached } \\
\text { Till, medium light gray, unoxidized, unleached } \\
\text { Till, medium light gray, unoxidized, unleached, } \\
\text { very sandy }\end{array}$}} \\
\hline & & 176 & & 180 & & & \\
\hline & & 180 & & 181 & & & \\
\hline \multirow{15}{*}{\multicolumn{2}{|c|}{$\begin{array}{l}\text { Pennsylvanian rocks, } \\
\text { undifferentiated }\end{array}$}} & 181 & & 187 & \multicolumn{3}{|c|}{$\begin{array}{l}\text { Limestone, very light gray; shale, gray; sand, } \\
\text { colorless, coarse to fine }\end{array}$} \\
\hline & & 187 & & 189 & \multicolumn{3}{|c|}{$\begin{array}{l}\text { Limestone, gray to very light gray, silt-grade, } \\
\text { partly argillaceous }\end{array}$} \\
\hline & & 189 & & 197 & \multirow{2}{*}{\multicolumn{3}{|c|}{$\begin{array}{l}\text { Shale, green, lumpy, silty, sandy } \\
\text { Limestone, very light gray to gray, silt-grade, } \\
\text { partly argillaceous; limestone, very light } \\
\text { gray, fine to medium }\end{array}$}} \\
\hline & & 197 & & 199 & & & \\
\hline & & 199 & & 202 & \multicolumn{3}{|c|}{$\begin{array}{l}\text { Limestone, very light gray, fine to medium, } \\
\text { partly argillaceous }\end{array}$} \\
\hline & & 202 & & 205 & \multirow{2}{*}{\multicolumn{3}{|c|}{$\begin{array}{l}\text { Limestone, very light gray, slightly argillaceous } \\
\text { Limestone, very light gray, slightly argillaceous; } \\
\text { shale, dark gray, carbonaceous }\end{array}$}} \\
\hline & & 205 & & 205.5 & & & \\
\hline & & 205.5 & & 206 & \multicolumn{3}{|c|}{ Shale, gray, micaceous } \\
\hline & & 206 & & 208.5 & \multirow{2}{*}{\multicolumn{3}{|c|}{$\begin{array}{l}\text { Shale, very dark gray, carbonaceous } \\
\text { Limestone, light gray, silt-grade, argillaceous }\end{array}$}} \\
\hline & & 208.5 & & 210 & & & \\
\hline & & 210 & & 213 & \multicolumn{3}{|c|}{$\begin{array}{l}\text { Limestone, gray, silt-grade, argillaceous, } \\
\text { fragmented }\end{array}$} \\
\hline & & 213 & & 215 & \multicolumn{3}{|c|}{ Limestone, silt-grade to fine; shale, gray } \\
\hline & & 215 & & 216 & \multicolumn{3}{|c|}{$\begin{array}{l}\text { Shale, gray; limestone, silt-grade to coarse, } \\
\text { fragmented }\end{array}$} \\
\hline & & 216 & & 218 & \multirow{2}{*}{\multicolumn{3}{|c|}{$\begin{array}{l}\text { Shale, gray; limestone, silt-grade to coarse } \\
\text { Limestone, silt-grade to medium, dolomitic }\end{array}$}} \\
\hline & & 218 & & 219 & & & \\
\hline $\begin{array}{l}\text { Southwest } \\
\text { Iowa study } \\
\text { identification } \\
\text { number } \\
\text { (fig. 1) } \\
\end{array}$ & \multicolumn{2}{|c|}{$\begin{array}{l}\text { Geological } \\
\text { Survey Bureau } \\
\text { jdentification } \\
\text { number }\end{array}$} & & $\begin{array}{l}\text { Township- } \\
\text { ange-section } \\
\text { dentification } \\
\text { number }\end{array}$ & $\begin{array}{c}\text { Latitude-longitude } \\
\text { identification } \\
\text { number } \\
\text { (DDMMSS-DDDMMSS) }\end{array}$ & $\begin{array}{l}\text { Land- } \\
\text { surface } \\
\text { altitude } \\
\text { (feet above } \\
\text { sea level) } \\
\end{array}$ & County \\
\hline SW14 & \multicolumn{2}{|c|}{ W-27713 } & \multicolumn{2}{|c|}{ 73-42-15BAAB } & $410751-0953947$ & 1,142 & Mills \\
\hline \multirow{2}{*}{\multicolumn{2}{|c|}{$\begin{array}{c}\text { Stratigraphic } \\
\text { unit }\end{array}$}} & \multicolumn{3}{|c|}{$\begin{array}{c}\text { Depth interval } \\
\text { (feet) }\end{array}$} & Description & & \\
\hline & & 0 & to & 3 & \multicolumn{3}{|l|}{ Roadbed (driller's log) } \\
\hline Quaternary depc & osits & 3 & to & 5 & \multicolumn{3}{|c|}{ Clay, dark gray-brown, silty (driller's log) } \\
\hline
\end{tabular}


Table 1. Geologic logs of test holes and observation wells drilled in southwest lowa, 1985-87--Continued

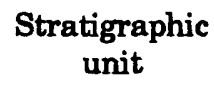

Depth interval (feet)

\section{SW14--Continued}

Quaternary deposits-Continued

Pleistocene deposits

Tertiary deposits

Pennsylvanian rocks,
undifferentiated

$\begin{array}{rlr}5 & \text { to } & 11 \\ 11 & \text { to } & 19 \\ & & \\ 19 & \text { to } & 30 \\ 30 & \text { to } & 42 \\ 42 & \text { to } & 43 \\ 43 & \text { to } & 50 \\ 50 & \text { to } & 65 \\ 65 & \text { to } & 70 \\ 70 & \text { to } & 75 \\ 75 & \text { to } & 80 \\ & & \\ 80 & \text { to } & 113 \\ 113 & \text { to } 116 \\ 116 & \text { to } & 118 \\ 118 & \text { to } & 119 \\ 119 & \text { to } & 124 \\ & & \\ 124 & \text { to } & 133\end{array}$

13

140

160

\begin{tabular}{|c|c|c|}
\hline 64 & to & 165 \\
\hline 165 & to & 168 \\
\hline 168 & to & 168.5 \\
\hline 168.5 & to & 169 \\
\hline 169 & to & 170 \\
\hline 170 & to & 171 \\
\hline 171 & to & 171.5 \\
\hline 171.5 & to & 172 \\
\hline 172 & to & 173 \\
\hline 173 & to & 174 \\
\hline 174 & to & 175 \\
\hline 175 & to & 177 \\
\hline 177 & to & 178 \\
\hline
\end{tabular}

Description
Silt, dark orange, argillaceous, calcareous Silt, very pale yellow, argillaceous, calcareous

Till, yellow, oxidized, unleached

Till, very pale yellow, oxidized, unleached

Till, very pale yellow, oxidized, unleached, sandy

Till, yellow-orange, oxidized, unleached

Till, orange-yellow, oxidized, unleached

Till, orange-brown, oxidized, unleached

Till, light olive-gray, unoxidized, unleached

Till, light olive-gray, unoxidized, unleached; till, orange, oxidized, unleached

Till, gray, unoxidized, unleached

Till, medium light gray, unoxidized, unleached

Till, gray-brown, unoxidized, unleached

Silt, brown, argillaceous, calcareous

Till, gray to very light gray, partly oxidized, unleached

Till, very light yellow gray, oxidized, partly unleached, partly leached

Sand, colorless and varicolored, fine to coarse, subrounded, partly polished; gravel, quartz, granite, limestone

Sand, colorless and varicolored, medium to coarse and fine, slightly silty, quartz, with trace dark heavy minerals

Sand, colorless and varicolored, coarse to fine; gravel, quartz and dark minerals

Gravel, igneous and metamorphic rocks; sand, varicolored, coarse, subrounded, dirty, quartz

Siderite, brown, massive; chert, gray; gravel, igneous and metamorphic rocks

Siderite, brown, massive, crystalline, and nodular

Siderite, brown, massive, crystalline, and nodular; sand, varicolored, argillaceous

Siderite, massive

Shale, brown, very dark gray, gray; siderite

Shale, very dark gray, lumpy

Shale, gray, sandy, calcareous, till-like

Shale, very dark gray, micaceous, blocky

Limestone, medium light gray, silt-grade to fine

Shale, gray and very dark gray, lumpy, calcareous

Shale, gray

Shale, very dark gray, silty, blocky

Limestone, mottled gray to brown 
Table 1. Geologic logs of test holes and observation wells drilled in southwest Iowa, 1985-87--Continued

\begin{tabular}{|c|c|c|c|c|c|c|c|}
\hline \multirow{2}{*}{$\begin{array}{c}\begin{array}{c}\text { Southwest } \\
\text { Iowa study } \\
\text { identification } \\
\text { number } \\
\text { (fig. 1) }\end{array} \\
\text { SW15 }\end{array}$} & \multicolumn{2}{|c|}{$\begin{array}{c}\text { Geological } \\
\text { Survey Bureau } \\
\text { identification } \\
\text { number } \\
\end{array}$} & \multicolumn{2}{|c|}{$\begin{array}{l}\text { Township- } \\
\text { range-section } \\
\text { identification } \\
\text { number }\end{array}$} & $\begin{array}{c}\text { Latitude-longitude } \\
\text { identification } \\
\text { number } \\
\text { (DDMMSS-DDDMMSS) }\end{array}$ & $\begin{array}{l}\text { Land- } \\
\text { surface } \\
\text { altitude } \\
\text { (feet above } \\
\text { sea level) }\end{array}$ & County \\
\hline & \multicolumn{2}{|c|}{ W-27714 } & \multicolumn{2}{|c|}{ 73-43-26CBAB } & $410541-0954546$ & 1,285 & Mills \\
\hline \multicolumn{2}{|c|}{$\begin{array}{l}\text { Stratigraphic } \\
\text { unit }\end{array}$} & \multicolumn{3}{|c|}{$\begin{array}{l}\text { Depth interval } \\
\text { (feet) }\end{array}$} & Description & & \\
\hline \multirow{16}{*}{\multicolumn{2}{|c|}{ Quaternary deposits }} & 0 & to & 5 & \\
\hline & & 5 & to & 15 & \multicolumn{3}{|c|}{ Silt, yellow-orange } \\
\hline & & 15 & to & 20 & \multicolumn{3}{|l|}{ Silt, orange } \\
\hline & & 20 & & 30 & \multicolumn{3}{|l|}{ Silt, yellow-orange } \\
\hline & & 30 & & 50 & \multirow{2}{*}{\multicolumn{3}{|c|}{ Silt, pale orange, slightly argillaceous }} \\
\hline & & 50 & & 60 & & & \\
\hline & & 60 & & 67 & \multicolumn{3}{|c|}{ Silt, orange and gray } \\
\hline & & 67 & to & 80 & \multicolumn{3}{|l|}{ Silt, orange, argillaceous } \\
\hline & & 80 & & 90 & \multicolumn{3}{|l|}{ Silt, orange-yellow } \\
\hline & & 90 & & 100 & \multicolumn{3}{|l|}{ Silt, yellow-orange } \\
\hline & & 100 & & 110 & \multicolumn{3}{|c|}{ Silt, very pale red-orange, argillaceous } \\
\hline & & 110 & & 120 & \multicolumn{3}{|c|}{ Silt, brown-orange, argillaceous } \\
\hline & & 120 & to & 130 & \multicolumn{3}{|l|}{ Silt, pale orange } \\
\hline & & 130 & to & 150 & \multicolumn{3}{|l|}{ Silt, very pale orange } \\
\hline & & 150 & to & 160 & \multicolumn{3}{|l|}{ Silt, very light gray } \\
\hline & & 160 & to & 169 & \multicolumn{3}{|c|}{ Silt, gray, very argillaceous } \\
\hline \multirow{9}{*}{\multicolumn{2}{|c|}{ Pleistocene deposits }} & 169 & to & 176 & \multirow{2}{*}{\multicolumn{3}{|c|}{$\begin{array}{l}\text { Till, light orange, oxidized, unleached } \\
\text { Till, light gray to orange, partly oxidized, } \\
\text { unleached }\end{array}$}} \\
\hline & & 176 & to & 190 & & & \\
\hline & & 190 & to & 205 & Till, pale orange, oxidize & ed, unleached & \\
\hline & & 205 & to & 216 & $\begin{array}{l}\text { Till, olive-gray, unoxidi } \\
\text { till, orange, oxidized, }\end{array}$ & $\begin{array}{l}\text { und, unleached, } \\
\text { unleached }\end{array}$ & vith trace \\
\hline & & 216 & to & 236 & $\begin{array}{l}\text { Gravel, varicolored, witl } \\
\text { calcareous matrix }\end{array}$ & $\mathrm{h}$ argillaceous, & lty, \\
\hline & & 236 & to & 270 & Till, olive-gray, unoxidiz & zed, unleached & \\
\hline & & 270 & to & 280 & $\begin{array}{l}\text { Till, olive-gray, unoxidiz } \\
\text { yellow, oxidized, unle }\end{array}$ & $\begin{array}{l}\text { ach, unleached; } \\
\text { ached }\end{array}$ & race till, \\
\hline & & 280 & to & 300 & Till, olive-gray, unoxidiz & ed, unleached; & ravel \\
\hline & & 300 & to & 317 & Till, olive-gray, unoxidiz & zed, unleached & \\
\hline Pennsylvan & rocks, & 317 & to & 340 & No samples & & \\
\hline undiffere & & 317 & to & 323 & Limestone; shale, gray- & green, silty (dri & er's log) \\
\hline & & 323 & to & 328 & Siltstone, gray-green (dr & riller's log) & \\
\hline & & 328 & to & 332 & $\begin{array}{l}\text { Limestone, gray-green } \\
\log )\end{array}$ & and tan, shaly ( & riller's \\
\hline & & 332 & to & 333 & Shale, gray (driller's log & & \\
\hline & & 333 & to & 335 & Limestone; shale, gray, & gray-green (dri & er's log) \\
\hline & & 335 & to & 338 & Shale, gray-green and $\mathrm{g}$ & ray (driller's lo & \\
\hline & & 338 & to & 339 & Limestone, blue-gray, sl & haley (driller's I & \\
\hline & & 339 & to & 340 & Shale, gray-green; limes & stone (driller's I & \\
\hline
\end{tabular}


Table 1. Geologic logs of test holes and observation wells drilled in southwest Iowa, 1985-87--Continued

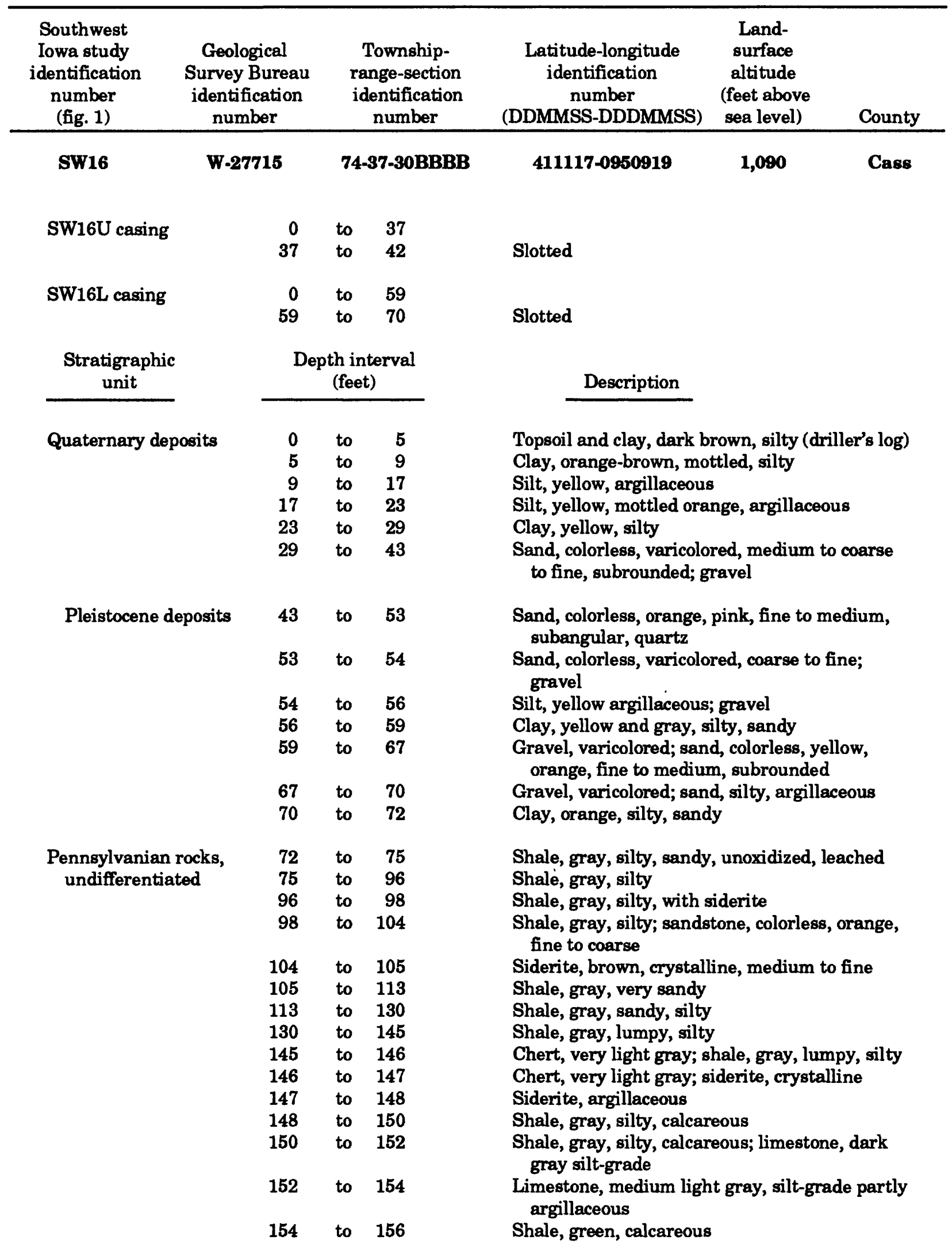


Table 1. Geologic logs of test holes and observation wells drilled in southwest Iowa, 1985-87--Continued

\begin{tabular}{|c|c|c|c|c|c|c|c|}
\hline \multirow{2}{*}{$\begin{array}{c}\begin{array}{c}\text { Southwest } \\
\text { Iowa study } \\
\text { identification } \\
\text { number } \\
\text { (fig. 1) }\end{array} \\
\text { SW17 }\end{array}$} & \multicolumn{2}{|c|}{$\begin{array}{l}\text { Geological } \\
\text { Survey Bureau } \\
\text { identification } \\
\text { number } \\
\end{array}$} & \multicolumn{2}{|c|}{$\begin{array}{l}\text { Township- } \\
\text { range-section } \\
\text { identification } \\
\text { number }\end{array}$} & \multirow{2}{*}{$\begin{array}{c}\begin{array}{c}\text { Latitude-longitude } \\
\text { identification } \\
\text { number }\end{array} \\
\text { (DDMMSS-DDDMMSS) } \\
\mathbf{4 1 1 9 0 0 - 0 9 4 5 5 3 0}\end{array}$} & \multirow{2}{*}{$\begin{array}{c}\begin{array}{c}\text { Land- } \\
\text { surface } \\
\text { altitude } \\
\text { (feet above } \\
\text { sea level) }\end{array} \\
1,295\end{array}$} & \multirow{2}{*}{ County } \\
\hline & $\mathbf{W}-2$ & 147 & 75 - & -35-07BBBA & & & \\
\hline SW17 casing & & $\begin{array}{r}0 \\
189\end{array}$ & & $\begin{array}{l}189 \\
209\end{array}$ & \multicolumn{3}{|l|}{ Slotted } \\
\hline $\begin{array}{c}\text { Stratigrap } \\
\text { unit }\end{array}$ & \multicolumn{4}{|c|}{$\begin{array}{c}\text { Depth interval } \\
\text { (feet) }\end{array}$} & \multicolumn{3}{|l|}{ Description } \\
\hline \multicolumn{2}{|c|}{ Quaternary deposits } & $\begin{array}{r}0 \\
10\end{array}$ & & $\begin{array}{l}10 \\
14\end{array}$ & \multicolumn{3}{|c|}{$\begin{array}{l}\text { Silt, yellow, argillaceous } \\
\text { Silt, orange-yellow, argillaceous }\end{array}$} \\
\hline \multirow{2}{*}{\multicolumn{2}{|c|}{ Pleistocene deposits }} & $\begin{array}{l}14 \\
17 \\
20\end{array}$ & & $\begin{array}{l}17 \\
20 \\
26\end{array}$ & \multicolumn{3}{|c|}{$\begin{array}{l}\text { Till, orange, oxidized, leached } \\
\text { Till, orange, oxidized, unleached } \\
\text { Till, orange, oxidized, unleached, weakly } \\
\text { calcareous }\end{array}$} \\
\hline & & $\begin{array}{r}26 \\
28 \\
55 \\
60 \\
75 \\
77 \\
83 \\
105 \\
131\end{array}$ & $\begin{array}{l}\text { to } \\
\text { to } \\
\text { to } \\
\text { to } \\
\text { to } \\
\text { to } \\
\text { to } \\
\text { to } \\
\text { to }\end{array}$ & $\begin{array}{r}28 \\
55 \\
60 \\
75 \\
77 \\
83 \\
105 \\
131 \\
138\end{array}$ & \multicolumn{3}{|c|}{$\begin{array}{l}\text { Silt, very light gray, argillaceous } \\
\text { Clay, light gray, silty } \\
\text { Till, yellow, oxidized, unleached } \\
\text { Till, pale orange, oxidized, unleached } \\
\text { Till, orange, oxidized, unleached } \\
\text { Till, light gray, oxidized, unleached } \\
\text { Till, yellow, oxidized, unleached } \\
\text { Till, very light yellow, oxidized, unleached } \\
\text { Till, very light gray, oxidized, unleached }\end{array}$} \\
\hline \multirow{5}{*}{\multicolumn{2}{|c|}{$\begin{array}{l}\text { Cretaceous rocks, } \\
\text { undifferentiated }\end{array}$}} & $\begin{array}{l}138 \\
140 \\
145\end{array}$ & & $\begin{array}{l}140 \\
145 \\
152\end{array}$ & \multicolumn{3}{|c|}{$\begin{array}{l}\text { Clay, gray, silty } \\
\text { Clay, gray, silty, very sandy } \\
\text { Sandstone, colorless, medium to coarse and } \\
\text { fine, angular, very silty, quartz }\end{array}$} \\
\hline & & 152 & to & 160 & \multicolumn{3}{|c|}{ Sandstone, colorless, orange, yellow, coarse to } \\
\hline & & 160 & to & 170 & \multicolumn{3}{|c|}{$\begin{array}{l}\text { Sandstone, orange, coarse to fine, angular, clean, } \\
\text { quartz }\end{array}$} \\
\hline & & 170 & to & 205 & \multicolumn{3}{|c|}{$\begin{array}{l}\text { Sandstone, orange, medium to coarse and fine, } \\
\text { angular, clean, quartz }\end{array}$} \\
\hline & & 205 & to & 210 & Gravel, varicolored; san & d, coarse, qua & chert \\
\hline \multirow{2}{*}{\multicolumn{2}{|c|}{$\begin{array}{l}\text { Pennsylvanian rocks, } \\
\text { undifferentiated }\end{array}$}} & 210 & to & 212 & \multirow{2}{*}{\multicolumn{3}{|c|}{$\begin{array}{l}\text { Gravel, varicolored; sand, coarse, quartz; chert; } \\
\text { shale, gray, lumpy, silty } \\
\text { Shale, green and yellow, sandy }\end{array}$}} \\
\hline & & 212 & to & 218 & & & \\
\hline
\end{tabular}


Table 1. Geologic logs of test holes and observation wells drilled in southwest Iowa, 1985-87--Continued

\begin{tabular}{cccccc}
\hline $\begin{array}{c}\text { Southwest } \\
\text { Iowa study } \\
\text { identification } \\
\text { number } \\
\text { (fig. 1) }\end{array}$ & $\begin{array}{c}\text { Geological } \\
\text { Survey Bureau } \\
\text { identification } \\
\text { number }\end{array}$ & $\begin{array}{c}\text { Township- } \\
\text { range-section } \\
\text { identification } \\
\text { number }\end{array}$ & $\begin{array}{c}\text { Latitude-longitude } \\
\text { identification } \\
\text { number }\end{array}$ & $\begin{array}{c}\text { Land- } \\
\text { surface } \\
\text { altitude } \\
\text { (feet above } \\
\text { (DDMMSS-DDDMMSS) }\end{array}$ & sealevel)
\end{tabular}

SW18 casing

Stratigraphic unit

Quaternary deposits

Pennsylvanian rocks, undifferentiated

$\begin{array}{rrr}0 & \text { to } 196 \\ 196 & \text { to } 201\end{array}$

Slotted

Depth interval (feet)

\begin{tabular}{rrr}
\multicolumn{3}{c}{ (feet) } \\
\hline & & \\
0 & to & 1 \\
1 & to & 5 \\
5 & to & 8 \\
8 & to & 23 \\
23 & to & 30 \\
& & \\
30 & to & 32 \\
32 & to & 40 \\
& & \\
40 & to & 59 \\
59 & to & 63 \\
63 & to & 70 \\
70 & to & 80 \\
80 & to & 103 \\
103 & to & 107 \\
107 & to & 120 \\
120 & to & 145 \\
& & \\
145 & to & 151 \\
151 & to & 157 \\
157 & to & 176 \\
& & \\
176 & to & 180 \\
& & \\
180 & to & 196
\end{tabular}

196 to 201

\section{Description}

Topsoil (driller's log)

Loess, light yellow, argillaceous

Loess, pale yellow, argillaceous

Clay, light gray

Clay, light gray; till, silty, sandy, highly oxidized, leached

Till, very light gray and orange, oxidized, leached

Till, very light gray and orange, oxidized, unleached

Till, yellow, oxidized, unleached

Till, gray, oxidized, unleached

Till, yellow, oxidized, unleached

Till, orange, oxidized, unleached

Till, pale yellow, oxidized, unleached

Till, pale yellow, unoxidized, unleached

Till, gray, unoxidized, unleached

Till, gray, unoxidized, unleached; till, yellow oxidized, unleached

Till, gray, oxidized, unleached

Till, yellow and orange, oxidized, partly leached

Till, medium light gray and yellow, partly oxidized, unleached

Till, medium dark gray and yellow, partly oxidized, unleached

Sand, colorless and orange, medium to coarse and fine, quartz; clay, brown, sandy, calcareous

Limestone, very light gray and dark gray, siltgrade to coarse 
Table 1. Geologic logs of test holes and observation wells drilled in southwest Iowa, 1985-87--Continued

\begin{tabular}{|c|c|c|c|c|c|c|c|}
\hline \multirow{2}{*}{$\begin{array}{c}\begin{array}{c}\text { Southwest } \\
\text { lowa study } \\
\text { identification } \\
\text { number } \\
\text { (fig. 1) }\end{array} \\
\text { SW19 }\end{array}$} & \multicolumn{2}{|c|}{$\begin{array}{c}\text { Geological } \\
\text { Survey Bureau } \\
\text { identification } \\
\text { number }\end{array}$} & \multicolumn{2}{|c|}{$\begin{array}{l}\text { Township- } \\
\text { range-section } \\
\text { identification } \\
\text { number }\end{array}$} & $\begin{array}{c}\text { Latitude-longitude } \\
\text { identification } \\
\text { number } \\
\text { (DDMMSS-DDDMMSS) }\end{array}$ & $\begin{array}{l}\text { Land- } \\
\text { surface } \\
\text { altitude } \\
\text { (feet above } \\
\text { sea level) }\end{array}$ & County \\
\hline & $\mathbf{W}-\mathbf{2}$ & & $72-$ & 39-12CBBB & 410308-0950337 & 1,285 & Montgomery \\
\hline \multicolumn{2}{|c|}{$\begin{array}{l}\text { Stratigraphic } \\
\text { unit }\end{array}$} & \multicolumn{3}{|c|}{$\begin{array}{l}\text { Depth interval } \\
\text { (feet) }\end{array}$} & Description & & \\
\hline \multicolumn{2}{|c|}{ Quaternary deposits } & $\begin{array}{r}0 \\
2 \\
14 \\
18 \\
20 \\
30 \\
40 \\
50 \\
57 \\
60\end{array}$ & & $\begin{array}{r}2 \\
14 \\
18 \\
20 \\
30 \\
40 \\
50 \\
57 \\
60 \\
75\end{array}$ & \multicolumn{3}{|c|}{$\begin{array}{l}\text { Topsoil and clay, brown (driller's log) } \\
\text { Silt, orange, argillaceous } \\
\text { Silt, pale yellow, argillaceous } \\
\text { Clay, gray and orange, silty } \\
\text { Silt, very light yellow, very argillaceous } \\
\text { Silt, very light gray } \\
\text { Silt, very light gray, very argillaceous } \\
\text { Shale, gray, silty } \\
\text { Shale, gray, silty, calcareous } \\
\text { Silt, yellow, calcareous }\end{array}$} \\
\hline \multirow{12}{*}{\multicolumn{2}{|c|}{ Pleistocene deposits }} & $\begin{array}{r}75 \\
112 \\
115\end{array}$ & & $\begin{array}{l}112 \\
115 \\
118\end{array}$ & \multicolumn{3}{|c|}{$\begin{array}{l}\text { Till, yellow, oxidized, unleached } \\
\text { Till, gray, medium light gray, oxidized, unleached } \\
\text { Till, light gray and pale orange, oxidized, } \\
\text { unleached }\end{array}$} \\
\hline & & 118 & to & 120 & \multicolumn{3}{|c|}{$\begin{array}{l}\text { Till, gray, unoxidized, leached; till, gray and pale } \\
\text { orange, oxidized, unleached }\end{array}$} \\
\hline & & 120 & to & 128 & \multicolumn{3}{|c|}{ Till, orange, oxidized, unleached } \\
\hline & & 128 & to & 140 & \multicolumn{3}{|c|}{ Clay, yellow, silty, slightly calcareous } \\
\hline & & 140 & to & 150 & \multicolumn{3}{|c|}{ Silt, yellow, argillaceous, calcareous } \\
\hline & & 150 & to & 158 & \multicolumn{3}{|c|}{ Silt, light gray, argillaceous, calcareous } \\
\hline & & 158 & to & 160 & \multirow{2}{*}{\multicolumn{3}{|c|}{$\begin{array}{l}\text { Till, yellow, oxidized, unleached } \\
\text { Sand, colorless and varicolored, very silty, very } \\
\text { argillaceous, medium to fine, poorly sorted, } \\
\text { quartz, with till-like matrix }\end{array}$}} \\
\hline & & 160 & to & 170 & & & \\
\hline & & 170 & to & 190 & \multirow{4}{*}{\multicolumn{3}{|c|}{$\begin{array}{l}\text { Silt, pale, calcareous, sandy, argillaceous } \\
\text { Till, very light gray, oxidized, unleached } \\
\text { Till, light orange, oxidized, unleached } \\
\text { Sand, colorless, varicolored, medium to fine, } \\
\text { quartz; gravel, silty, argillaceous, calcareous; } \\
\text { igneous and metamorphic rocks }\end{array}$}} \\
\hline & & 190 & to & 195 & & & \\
\hline & & 195 & to & 200 & & & \\
\hline & & 200 & to & 210 & & & \\
\hline \multirow{8}{*}{\multicolumn{2}{|c|}{$\begin{array}{l}\text { Pennsylvanian rocks, } \\
\text { undifferentiated }\end{array}$}} & 210 & to & 220 & \multirow{4}{*}{\multicolumn{3}{|c|}{$\begin{array}{l}\text { Shale, gray, lumpy, silty, soft } \\
\text { Shale, olive-gray, silty, slightly calcareous, till-like } \\
\text { Sandstone, colorless, varicolored, coarse to fine; } \\
\text { shale, olive-gray, silty, slightly calcareous, till-like } \\
\text { Shale, yellow, silty, slightly calcareous, till-like }\end{array}$}} \\
\hline & & 220 & to & 252 & & & \\
\hline & & 252 & to & 260 & & & \\
\hline & & 260 & to & 261 & & & \\
\hline & & 261 & to & 262 & \multicolumn{3}{|c|}{$\begin{array}{l}\text { Dolostone, very light gray, silt-grade, very } \\
\text { calcareous }\end{array}$} \\
\hline & & 262 & to & 263 & \multicolumn{3}{|l|}{ Shale, gray-green, lumpy } \\
\hline & & 263 & to & 267 & \multirow{2}{*}{\multicolumn{3}{|c|}{ Shale, green, maroon, tan }} \\
\hline & & 267 & to & 270 & & & \\
\hline
\end{tabular}


Table 1. Geologic logs of test holes and observation wells drilled in southwest Iowa, 1985-87--Continued

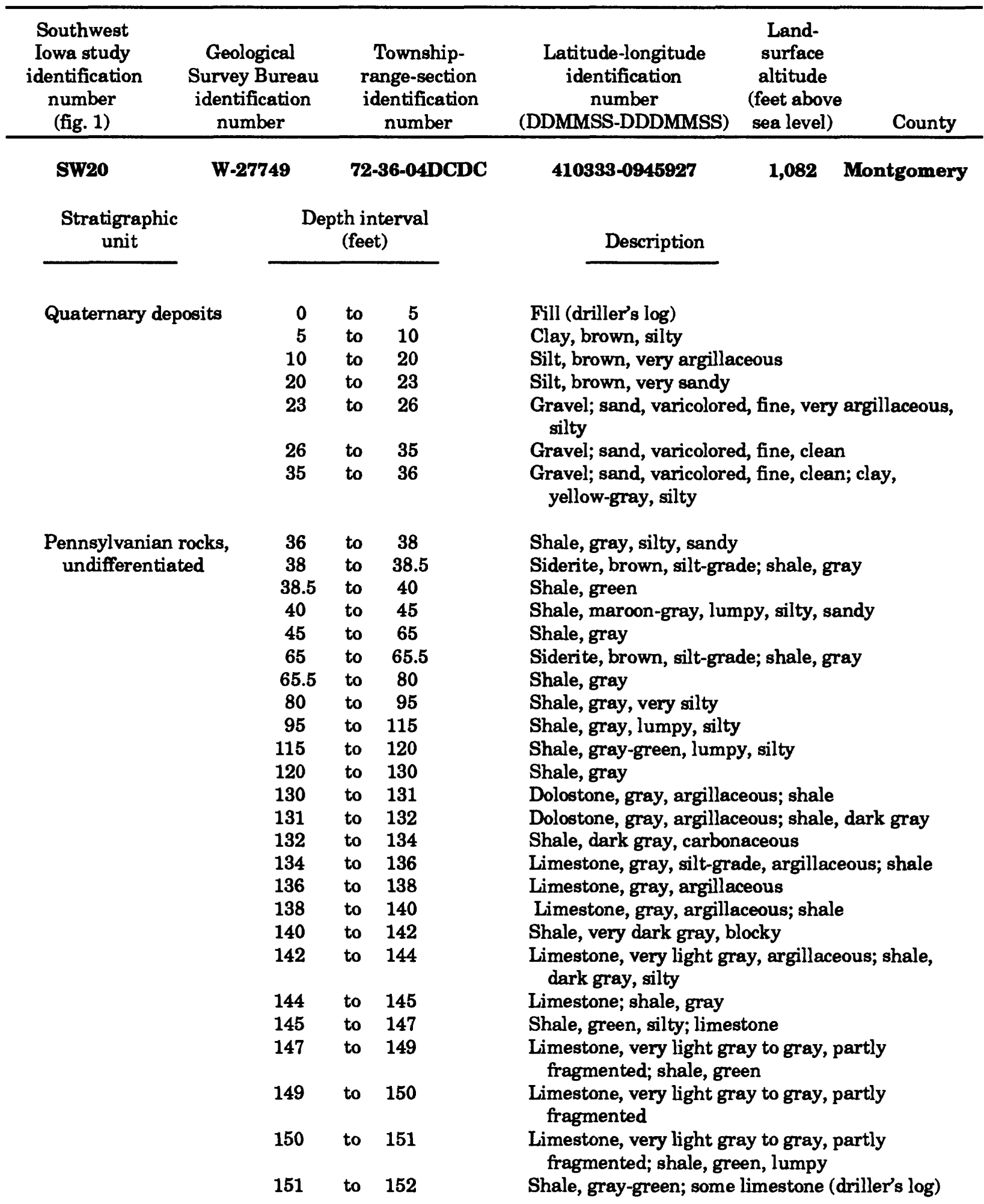


Table 1. Geologic logs of test holes and observation wells drilled in southwest Iowa, 1985-87--Continued

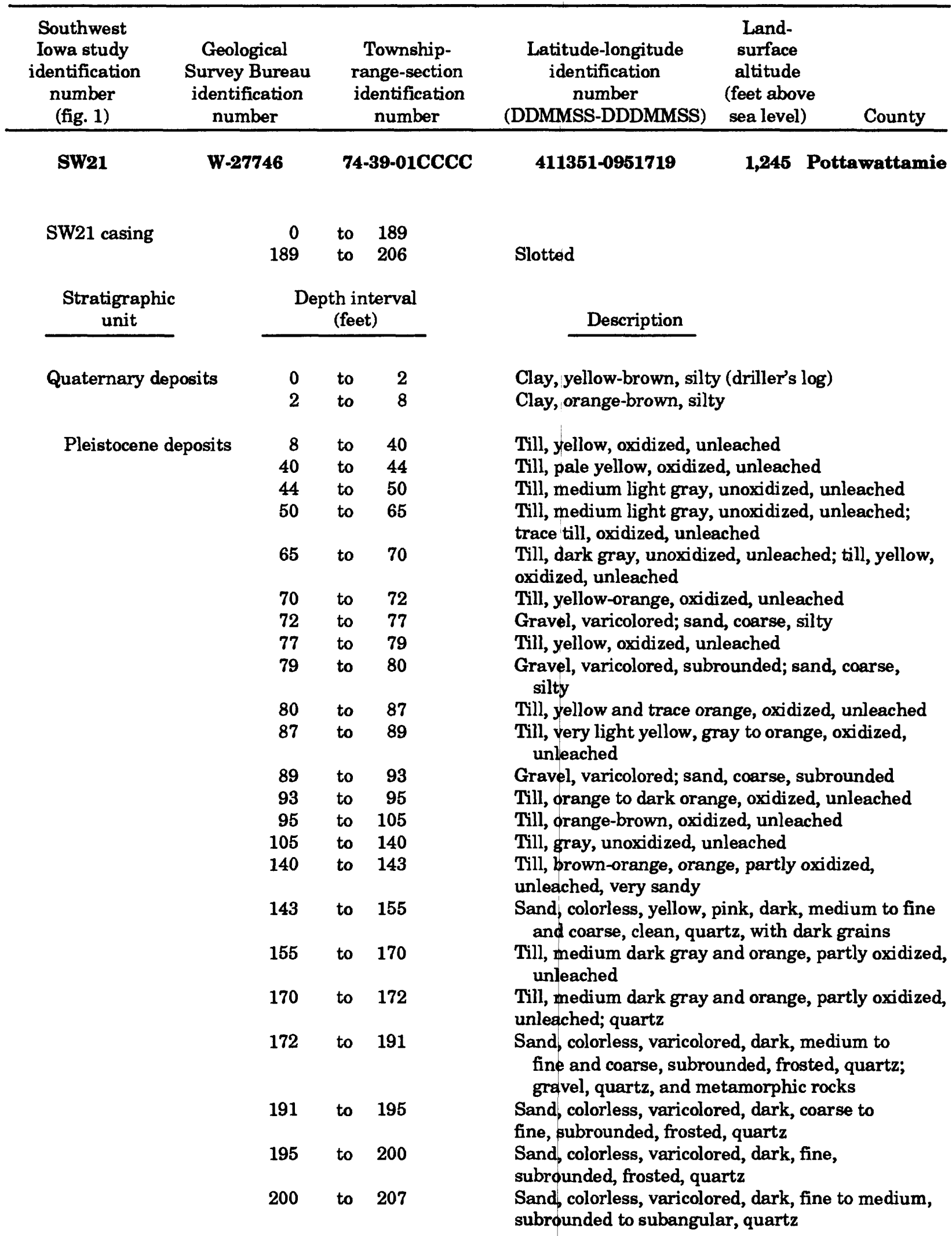


Table 1. Geologic logs of test holes and observation wells drilled in southwest lowa, 1985-87--Continued

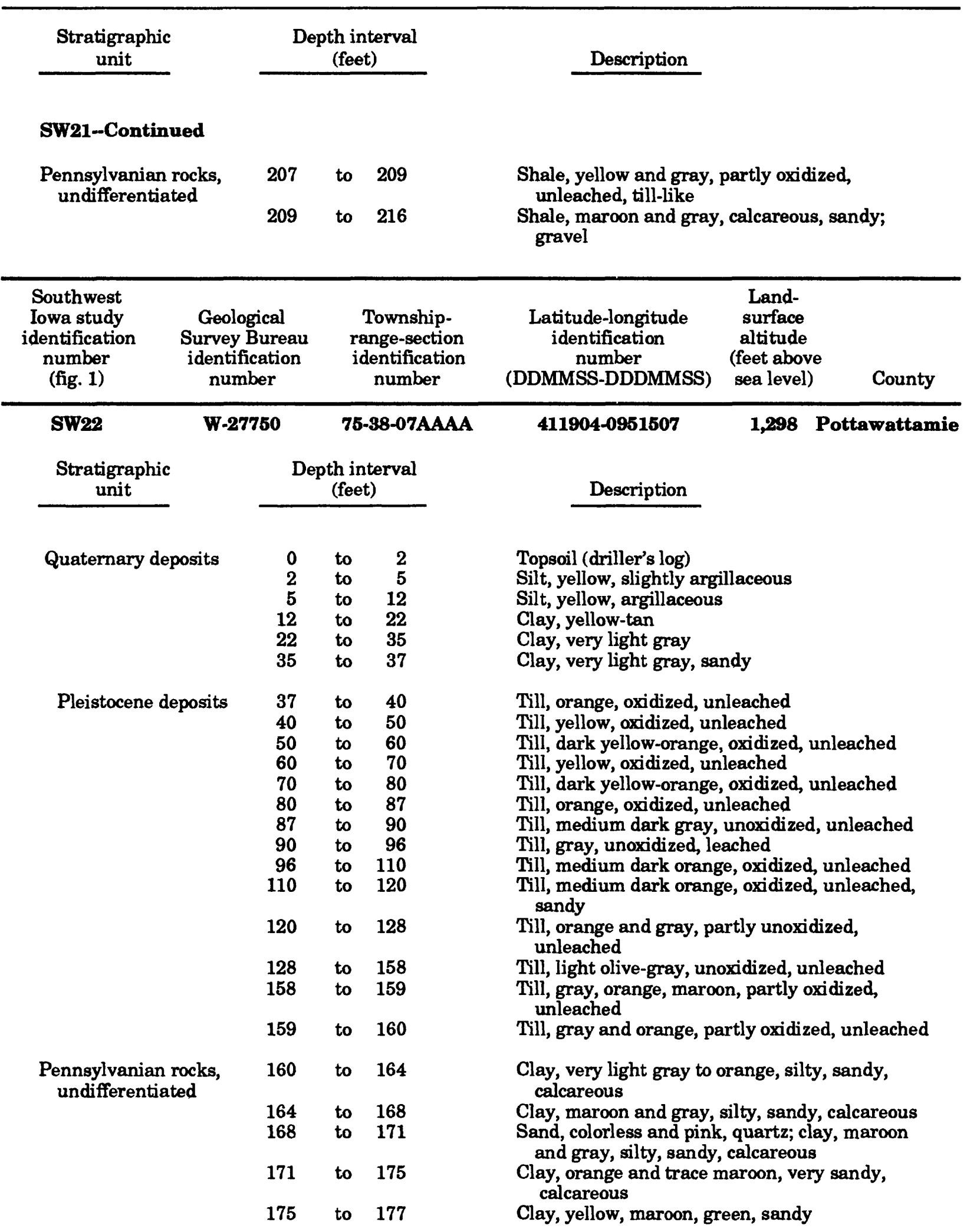


Table 1. Geologic logs of test holes and observation wells drilled in southwest Iowa, 1985-87--Continued

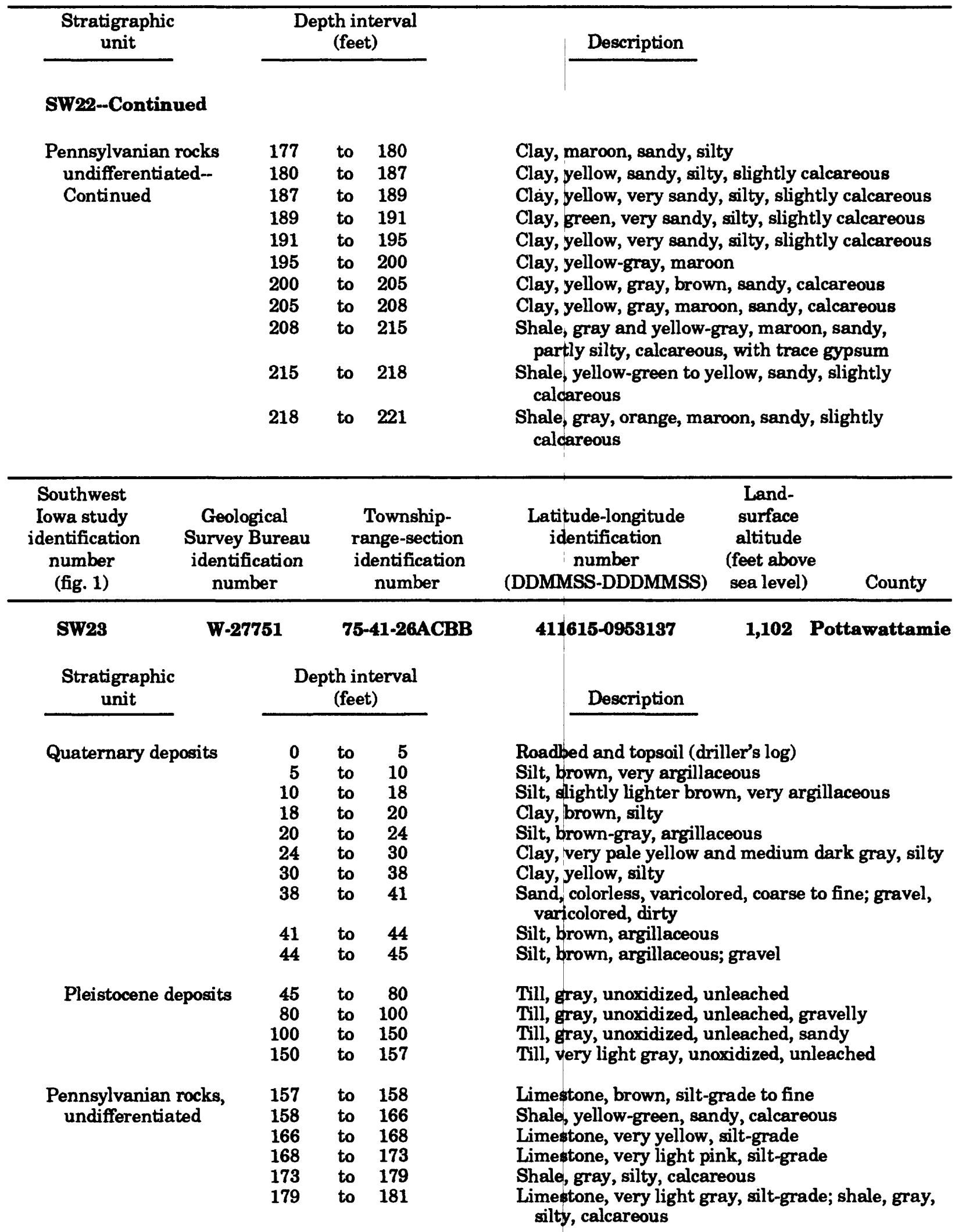


Table 1. Geologic logs of test holes and observation wells drilled in southwest Iowa, 1985-87--Continued

\begin{tabular}{|c|c|c|c|c|c|c|c|}
\hline \multirow{2}{*}{$\begin{array}{c}\begin{array}{c}\text { Southwest } \\
\text { Iowa study }\end{array} \\
\text { identification } \\
\begin{array}{c}\text { number } \\
\text { (fig. 1) }\end{array} \\
\text { SW24 }\end{array}$} & \multicolumn{2}{|c|}{$\begin{array}{l}\text { Geological } \\
\text { Survey Bureau } \\
\text { identification } \\
\text { number }\end{array}$} & \multicolumn{2}{|c|}{$\begin{array}{l}\text { Township- } \\
\text { range-section } \\
\text { identification } \\
\text { number }\end{array}$} & $\begin{array}{c}\text { Latitude-longitude } \\
\text { identification } \\
\text { number } \\
\text { (DDMMSS-DDDMMSS) }\end{array}$ & $\begin{array}{c}\text { Land- } \\
\text { surface } \\
\text { altitude } \\
\text { (feet above } \\
\text { sea level) }\end{array}$ & County \\
\hline & $\mathbf{W}-\mathbf{2}$ & & & 41-29DDDD & $412051-0953431$ & $1,215 \mathrm{P}$ & Pottawattamie \\
\hline \multicolumn{2}{|c|}{$\begin{array}{l}\text { Stratigraphic } \\
\text { unit }\end{array}$} & \multicolumn{3}{|c|}{$\begin{array}{l}\text { Depth interval } \\
\text { (feet) }\end{array}$} & Description & & \\
\hline \multirow{10}{*}{\multicolumn{2}{|c|}{ Quaternary deposits }} & 0 & to & 5 & \multirow{10}{*}{\multicolumn{3}{|c|}{$\begin{array}{l}\text { Roadbed and topsoil (driller log) } \\
\text { Clay, medium dark brown-gray, silty } \\
\text { Clay, brown, silty } \\
\text { Silt, brown, very argillaceous } \\
\text { Silt, brown, very argillaceous, calcareous } \\
\text { Silt, medium light brown-gray, very argillaceous } \\
\text { Clay, light gray, silty } \\
\text { Silt, very light yellow } \\
\text { Silt, pale orange and gray, very argillaceous, } \\
\text { calcareous } \\
\text { Clay, brown-gray, silty, slightly calcareous }\end{array}$}} \\
\hline & & 5 & to & 10 & & & \\
\hline & & 10 & to & 12 & & & \\
\hline & & 12 & to & 20 & & & \\
\hline & & 20 & to & 24 & & & \\
\hline & & 24 & to & 31 & & & \\
\hline & & 31 & to & 34 & & & \\
\hline & & 34 & to & 39 & & & \\
\hline & & 39 & to & 42 & & & \\
\hline & & 42 & to & 51 & & & \\
\hline \multirow{10}{*}{\multicolumn{2}{|c|}{ Pleistocene deposits }} & 51 & to & 78 & \multirow{3}{*}{\multicolumn{3}{|c|}{$\begin{array}{l}\text { Till, orange, oxidized, unleached } \\
\text { Till, orange-brown, partly oxidized, unleached } \\
\text { Till, brown-gray, unoxidized, unleached; trace till, } \\
\text { orange, oxidized, unleached }\end{array}$}} \\
\hline & & 78 & to & 80 & & & \\
\hline & & 80 & to & 100 & & & \\
\hline & & 100 & to & 110 & \multirow{2}{*}{\multicolumn{3}{|c|}{$\begin{array}{l}\text { Till, light olive-gray, unoxidized, unleached } \\
\text { Till, light olive-gray, unoxidized, unleached }\end{array}$}} \\
\hline & & 110 & to & 140 & & & leached \\
\hline & & 140 & to & 145 & \multicolumn{3}{|c|}{ Till, brown-gray, unoxidized, unleached } \\
\hline & & 145 & to & 150 & \multicolumn{3}{|c|}{ Till, light olive-gray, unoxidized, unleached } \\
\hline & & 150 & to & 164 & \multicolumn{3}{|c|}{$\begin{array}{l}\text { Till or clay, gray to light gray, calcareous, very silty, } \\
\text { slightly sandy }\end{array}$} \\
\hline & & 164 & to & 169 & \multicolumn{3}{|c|}{$\begin{array}{l}\text { Silt, very light gray, argillaceous, very slightly } \\
\text { calcareous, with trace sand }\end{array}$} \\
\hline & & 169 & to & 169.5 & \multicolumn{3}{|c|}{$\begin{array}{l}\text { Chert, gray to brown-gray, smooth; sand, } \\
\text { colorless, varicolored }\end{array}$} \\
\hline \multirow{7}{*}{\multicolumn{2}{|c|}{$\begin{array}{l}\text { Pennsylvanian rocks, } \\
\text { undifferentiated }\end{array}$}} & 169.5 & to & 174 & \multirow{7}{*}{\multicolumn{3}{|c|}{$\begin{array}{l}\text { Shale, orange, silty, lumpy; shale, gray, lumpy; } \\
\text { chert, gray to brown-gray, smooth } \\
\text { Shale, green and orange, lumpy } \\
\text { Shale, green and orange, lumpy; } \\
\text { Limestone, very light gray, silt-grade to fine, } \\
\text { dolomitic } \\
\text { Limestone, pale yellow, silt-grade to fine, dolomitic } \\
\text { Shale, gray, lumpy, silty } \\
\text { Limestone, very light gray, silt-grade to fine, } \\
\text { dolomitic }\end{array}$}} \\
\hline & & 174 & & 176 & & & \\
\hline & & 176 & & 178 & & & \\
\hline & & 178 & to & 180 & & & \\
\hline & & 180 & to & 182 & & & \\
\hline & & 182 & & 184 & & & \\
\hline & & 184 & to & 186 & & & \\
\hline
\end{tabular}


Table 1. Geologic logs of test holes and observation wells drilled in southwest Iowa, 1985-87--Continued

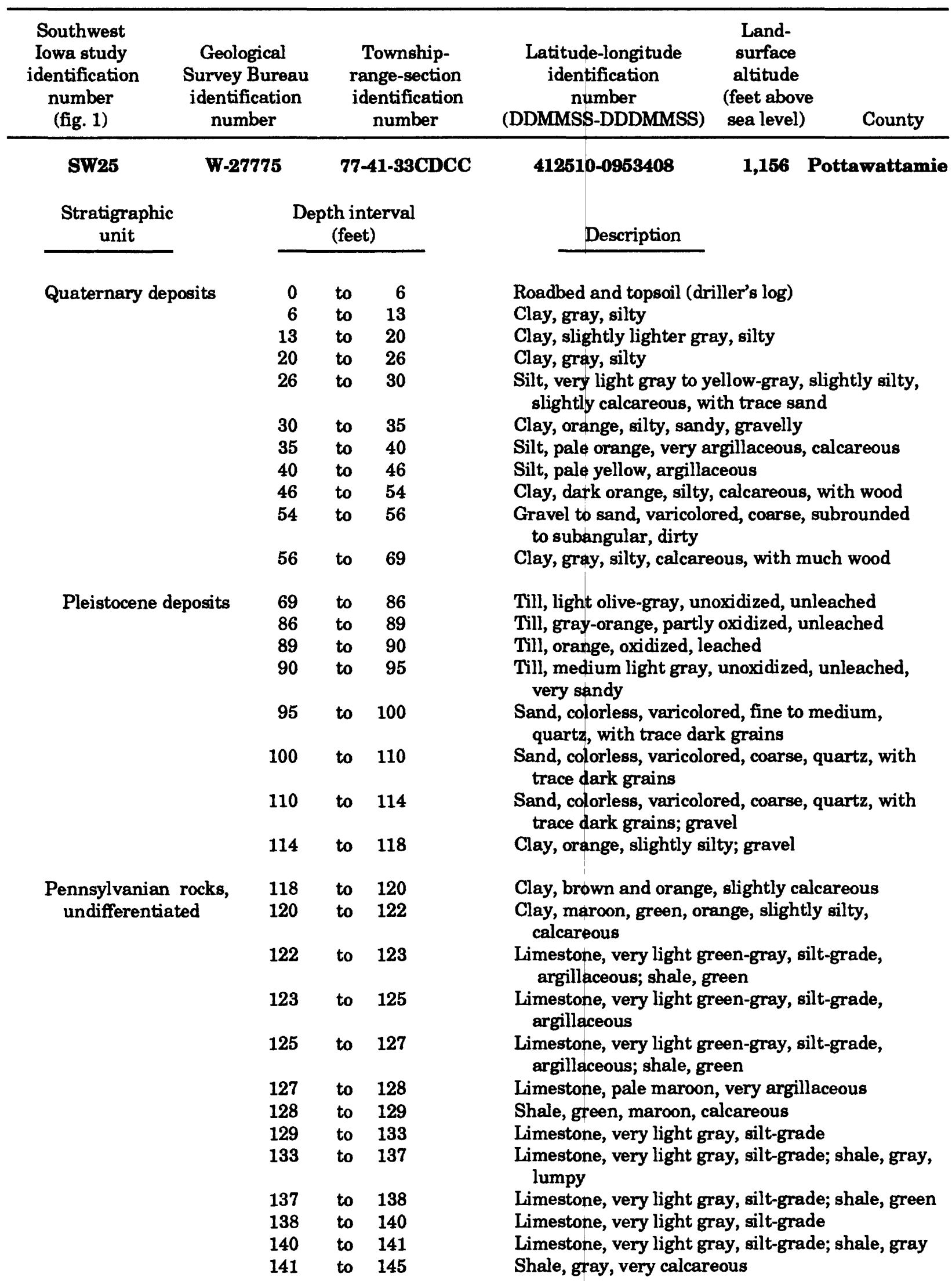


Table 1. Geologic logs of test holes and observation wells drilled in southwest Iowa, 1985-87--Continued

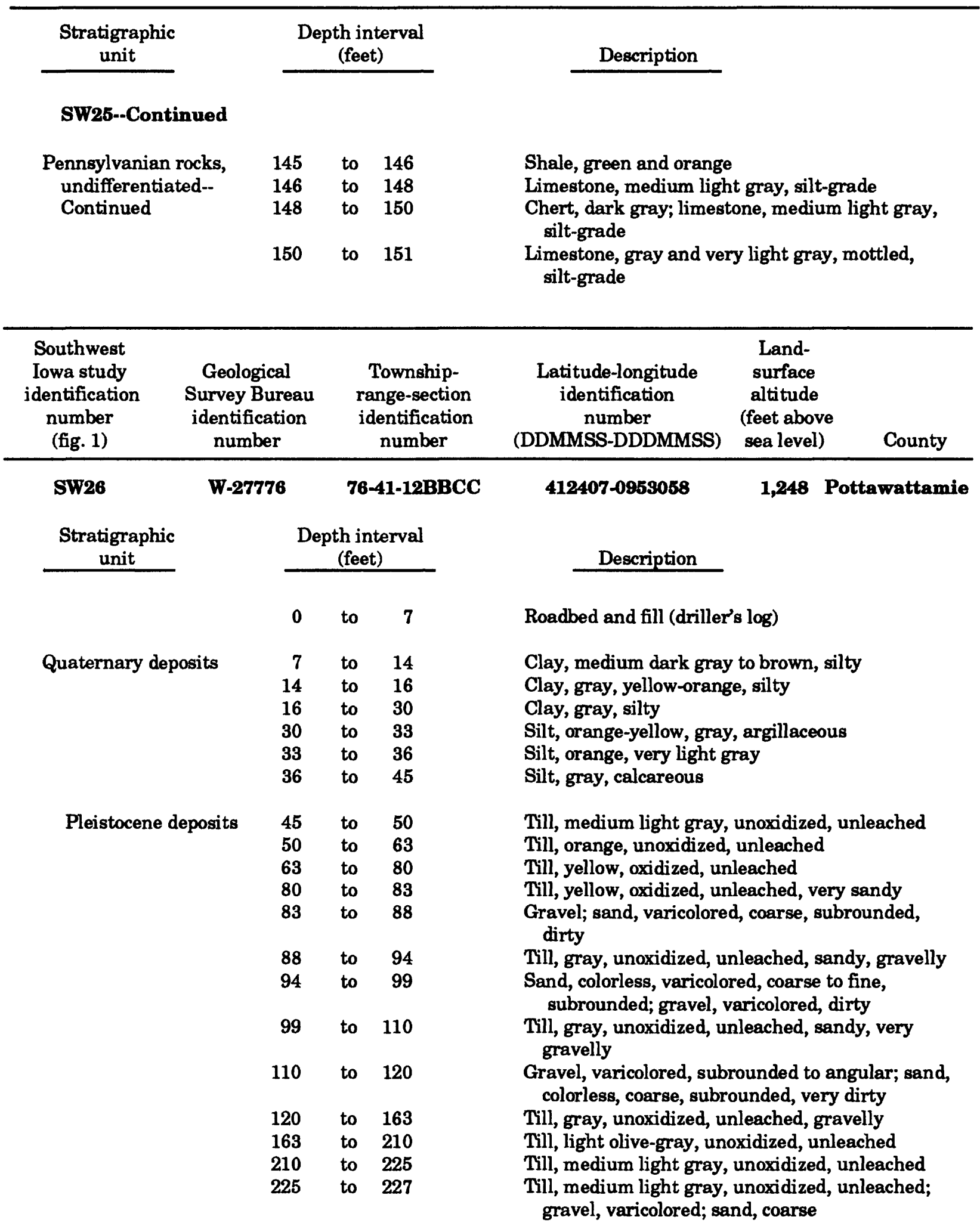


Table 1. Geologic logs of test holes and observation wells drilled in southwest Iowa, 1985-87--Continued

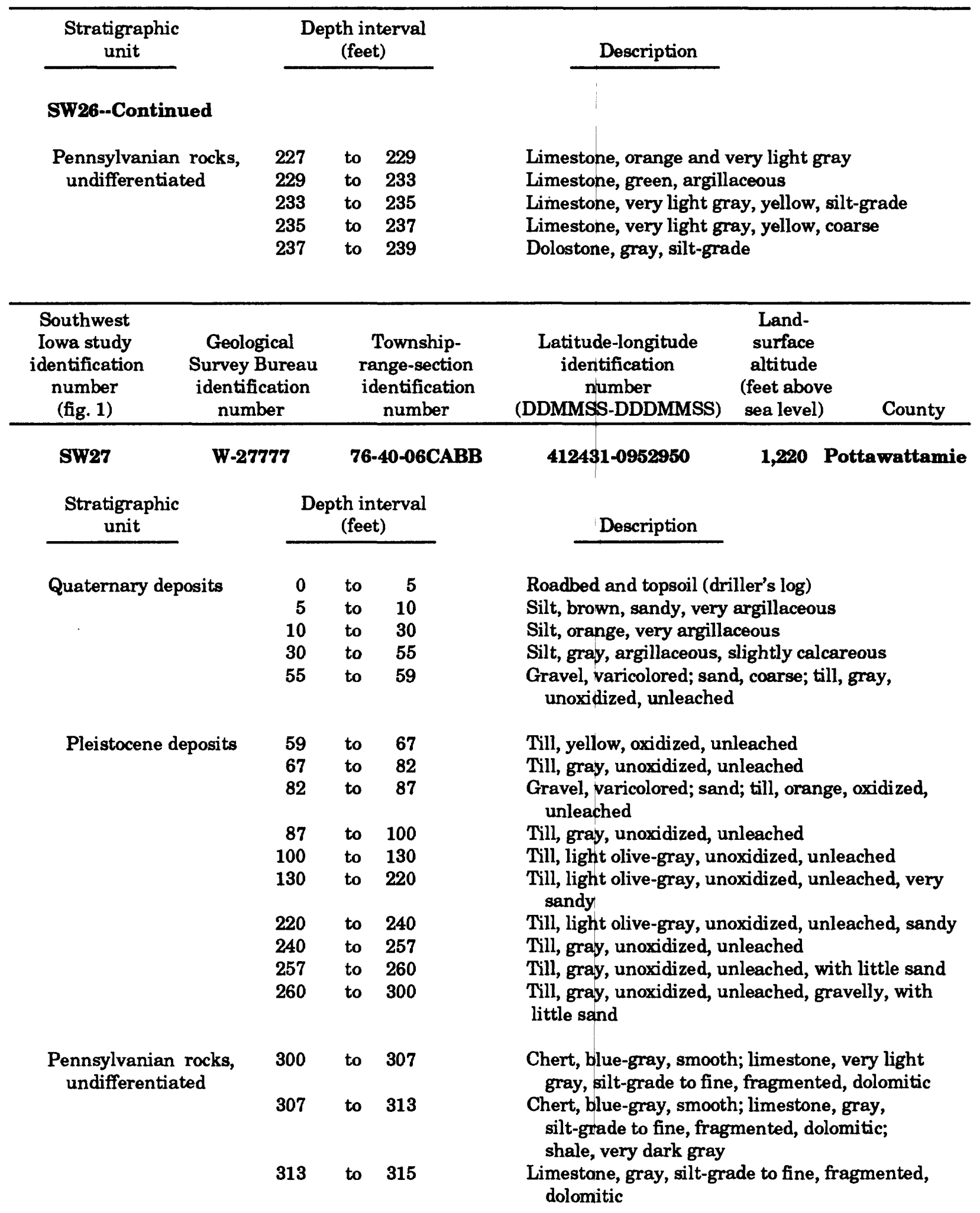


Table 1. Geologic logs of test holes and observation wells drilled in southwest lowa, 1985-87--Continued

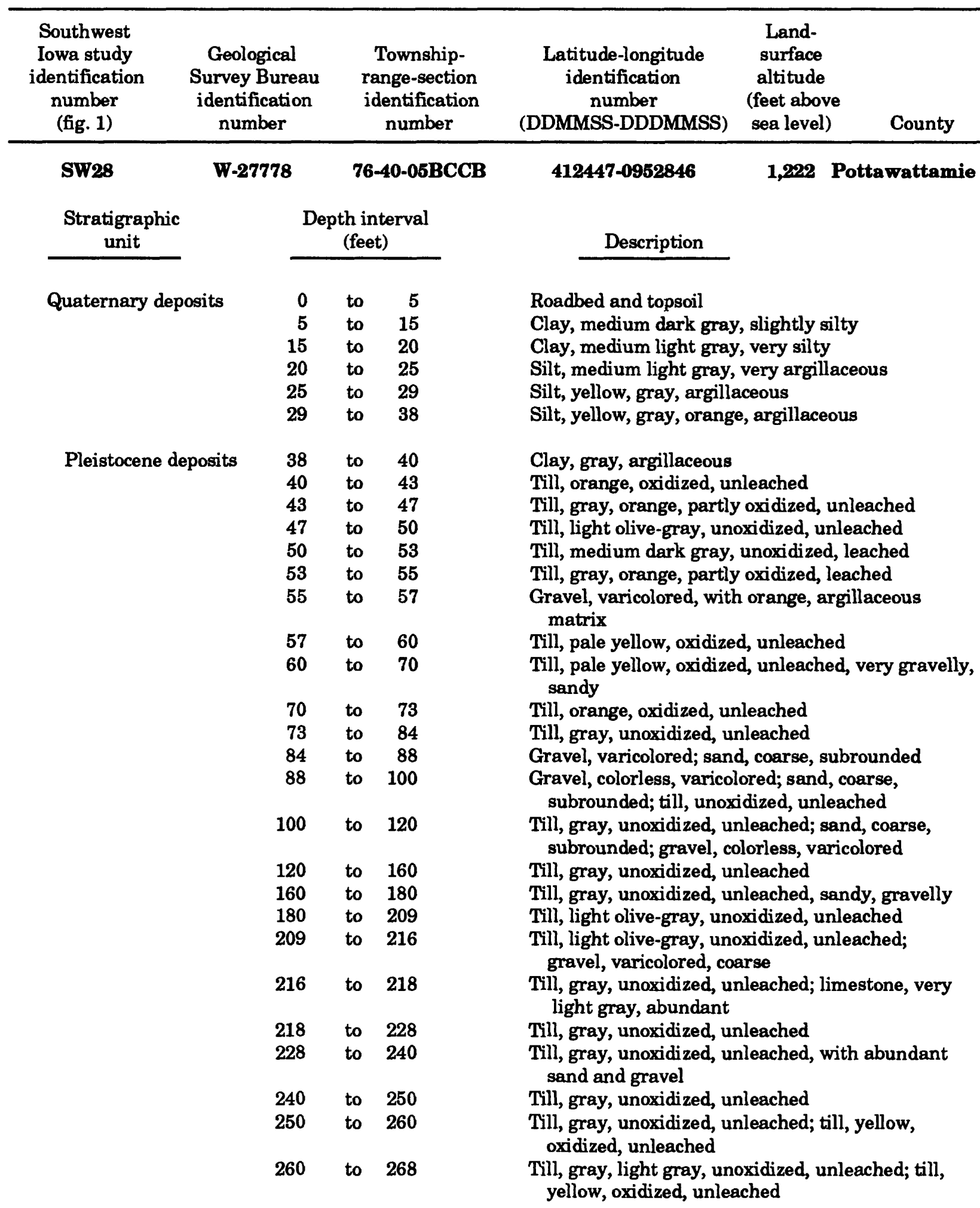


Table 1. Geologic logs of test holes and observation wells drilled in southwest Iowa, 1985-87--Continued

\begin{tabular}{|c|c|c|c|}
\hline $\begin{array}{l}\text { Stratigraphic } \\
\text { unit }\end{array}$ & \multicolumn{2}{|c|}{$\begin{array}{l}\text { Depth interval } \\
\text { (feet) }\end{array}$} & Description \\
\hline \multicolumn{4}{|l|}{ SW28--Continued } \\
\hline $\begin{array}{l}\text { Pennsylvanian rocks, } \\
\text { undifferentiated }\end{array}$ & $\begin{array}{l}268 \\
272 \\
273 \\
275 \\
278 \\
281 \\
287\end{array}$ & $\begin{array}{l}\text { to } 272 \\
\text { to } 273 \\
\text { to } 275 \\
\text { to } 278 \\
\text { to } 281 \\
\text { to } 287 \\
\text { to } 289\end{array}$ & $\begin{array}{l}\text { Limestone, very light gray, silt-grade to fine } \\
\text { Shale, green, gray, lumpy } \\
\text { Shale, very dark gray, blocky } \\
\text { Shale, gray, lumpy, calcareous } \\
\text { Shale, green-gray, lumpy, calcareous } \\
\text { Chert, very light gray } \\
\text { Limestone, very light gray, silt-grade to medium } \\
\text { fragmented }\end{array}$ \\
\hline
\end{tabular}

\begin{tabular}{cccccc}
\hline $\begin{array}{c}\text { Southwest } \\
\text { Iowa study } \\
\text { identification } \\
\text { number } \\
\text { (fig. 1) }\end{array}$ & $\begin{array}{c}\text { Geological } \\
\text { Survey Bureau } \\
\text { identification } \\
\text { number }\end{array}$ & $\begin{array}{c}\text { Township- } \\
\text { range-section } \\
\text { identification } \\
\text { number }\end{array}$ & $\begin{array}{c}\text { Latitude-longitude } \\
\text { identification } \\
\text { number } \\
\text { (DDMMSS-DDDMMSS) }\end{array}$ & $\begin{array}{c}\text { Land- } \\
\text { surface } \\
\text { altitude } \\
\text { (feet above } \\
\text { sea level) }\end{array}$ & County \\
\hline SW29 & $\mathbf{W - 2 7 7 7 9 9}$ & $\begin{array}{c}\mathbf{7 6 - 4 0 - 0 9 B A A B} \\
\text { Depth interval } \\
\text { (feet) }\end{array}$ & $\mathbf{4 1 2 4 1 5 - 0 9 5 2 7 1 0}$ & $\mathbf{1 , 1 6 5}$ Pottawattamie \\
$\begin{array}{c}\text { Stratigraphic } \\
\text { unit }\end{array}$ & nescription & & \\
\hline
\end{tabular}

$\begin{array}{lrrr}\text { Quaternary deposits } & 0 & \text { to } & 5 \\ 5 & \text { to } & 9 \\ 9 & \text { to } & 18 \\ 18 & \text { to } & 30 \\ 30 & \text { to } & 34 \\ & 34 & \text { to } & 38 \\ & & & \\ \text { Pleistocene deposits } & 38 & \text { to } & 40 \\ & & & \\ 40 & \text { to } & 80 \\ 80 & \text { to } & 120 \\ 120 & \text { to } & 140 \\ 140 & \text { to } & 160 \\ 160 & \text { to } & 180 \\ 180 & \text { to } & 230 \\ 230 & \text { to } & 240 \\ & 240 & \text { to } & 245 \\ & & \\ & 245 & \text { to } & 260 \\ 260 & \text { to } & 280 \\ & & \\ & 280 & \text { to } 300 \\ & & \\ & 300 & \text { to } 320 \\ & & \\ 320 & \text { to } 330\end{array}$

Roadbed and topsoil (driller's log)

Clay, dark gray, silty

Clay, medium light gray, silty

Silt, light gray, argillaceous

Silt, light gray, argillaceous, calcareous

Silt, medium light gray, argillaceous, calcareous

Silt, medium light gray, argillaceous, calcareous, sandy, gravelly, unoxidized, unleached

Till, gray, unoxidized, unleached

Till, medium light gray, unoxidized, unleached

Till, gray

Till, medium light gray

Till, blue-gray (driller's log)

Till, light olive-gray, unoxidized, unleached

Till, blue-gray, very sandy (driller's log)

Gravel, varicolored; sand, coarse; till, light olive-gray, unoxidized, unleached

Till, light olive-gray, unoxidized, unleached

Sand, colorless, dark, varicolored, medium to coarse and fine, very argillaceous, quartz

Sand, colorless, dark, varicolored, medium to coarse and fine, clean, quartz

Sand, gray-tan, fine to coarse, with clay at the base (driller's log)

Sand, colorless, dark, varicolored, medium to coarse and fine, quartz 
Table 1. Geologic logs of test holes and observation wells drilled in southwest Iowa, 1985-87--Continued

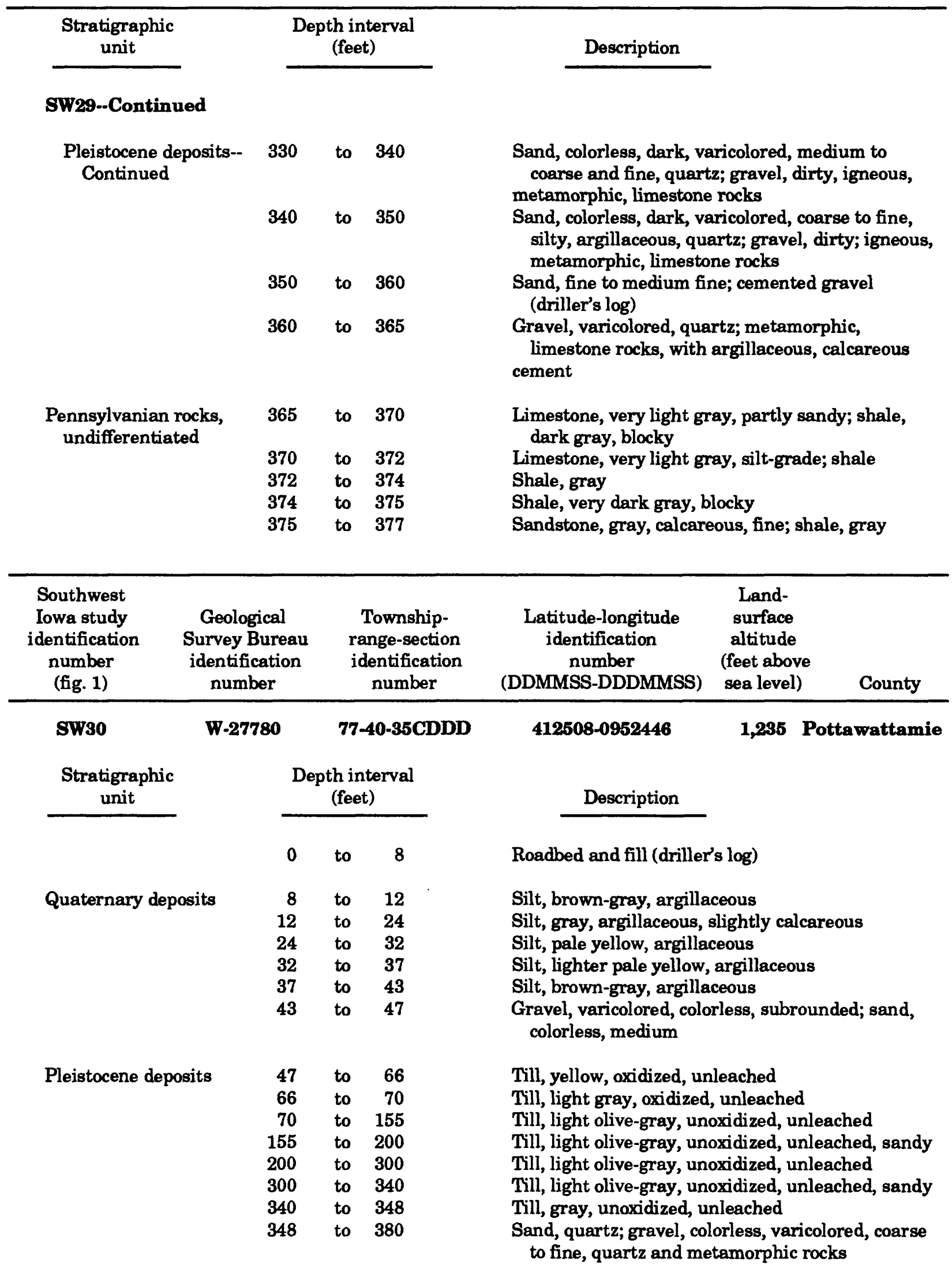


Table 1. Geologic logs of test holes and observation wells drilled in southwest lowa, 1985-87--Continued

\begin{tabular}{|c|c|c|c|c|c|}
\hline $\begin{array}{l}\text { Stratigraphic } \\
\text { unit }\end{array}$ & \multicolumn{3}{|c|}{$\begin{array}{l}\text { Depth interval } \\
\text { (feet) }\end{array}$} & Description & \\
\hline \multicolumn{6}{|l|}{ SW30-.Continued } \\
\hline $\begin{array}{l}\text { Pleistocene deposits-- } \\
\text { Continued }\end{array}$ & $\begin{array}{l}380 \\
396\end{array}$ & & $\begin{array}{l}396 \\
399\end{array}$ & \multicolumn{2}{|c|}{$\begin{array}{l}\text { Sand, quartz; gravel, colorless, varicolored, coarse } \\
\text { to fine, clean, quartz and metamorphic rocks } \\
\text { Gravel, colorless, varicolored, coarse to fine, } \\
\text { clean, quartz and metamorphic rocks; } \\
\text { limestone, very light gray, silt-grade, dolomitic }\end{array}$} \\
\hline $\begin{array}{l}\text { Pennsylvanian rocks, } \\
\text { undifferentiated }\end{array}$ & $\begin{array}{l}399 \\
400 \\
405 \\
408\end{array}$ & & $\begin{array}{l}400 \\
405 \\
408 \\
411\end{array}$ & \multicolumn{2}{|c|}{$\begin{array}{l}\text { Shale, very light gray } \\
\text { Shale, gray, lumpy, silty, calcareous } \\
\text { Dolostone, very light gray, silt-grade } \\
\text { Limestone, very light gray, silt-grade }\end{array}$} \\
\hline $\begin{array}{l}\text { Southwest } \\
\text { Iowa study } \\
\text { identification } \\
\text { number } \\
\text { (fig. 1) } \\
\end{array}$ & $\begin{array}{l}\text { ical } \\
\text { ureau } \\
\text { ation } \\
\text { er }\end{array}$ & & $\begin{array}{l}\text { Township- } \\
\text { unge-section } \\
\text { lentification } \\
\text { number }\end{array}$ & $\begin{array}{c}\text { Latitude-longitude } \\
\text { identification } \\
\text { number } \\
\text { (DDMMSS-DDDMMSS) }\end{array}$ & $\begin{array}{l}\text { Land- } \\
\text { surface } \\
\text { altitude } \\
\text { (feet above } \\
\text { sea level) } \\
\end{array}$ \\
\hline Sw31 & & & -39-05BCCC & 412443-0952155 & 1,125 Pottawattamie \\
\hline \multirow[t]{2}{*}{$\begin{array}{c}\text { Stratigraphic } \\
\text { unit }\end{array}$} & \multicolumn{3}{|c|}{$\begin{array}{l}\text { Depth interval } \\
\text { (feet) }\end{array}$} & Description & \\
\hline & 0 & to & 5 & Roadbed and fill (drilles & s log) \\
\hline Quaternary deposits & $\begin{array}{r}5 \\
20 \\
31\end{array}$ & & $\begin{array}{l}20 \\
31 \\
39\end{array}$ & $\begin{array}{l}\text { Silt, yellow-orange, arg } \\
\text { Silt, light gray, trace or } \\
\text { Gravel, orange, varicolc }\end{array}$ & $\begin{array}{l}\text { laceous } \\
\text { unge, argillaceous } \\
\text { red; sand, medium }\end{array}$ \\
\hline Pleistocene deposits & $\begin{array}{l}39 \\
60\end{array}$ & & $\begin{array}{r}60 \\
109\end{array}$ & $\begin{array}{l}\text { Till, gray, unoxidized, u } \\
\text { Till, light olive-gray, un }\end{array}$ & $\begin{array}{l}\text { nleached } \\
\text { oxidized, unleached, sandy }\end{array}$ \\
\hline \multirow[t]{10}{*}{$\begin{array}{l}\text { Pennsylvanian rocks, } \\
\text { undifferentiated }\end{array}$} & 109 & to & 111 & $\begin{array}{l}\text { Limestone, very light g } \\
\text { shale, light gray, lum }\end{array}$ & $\begin{array}{l}\text { ay, silt-grade, argillaceous; } \\
\text { oy }\end{array}$ \\
\hline & 111 & to & 113 & $\begin{array}{l}\text { Dolostone, very light gr } \\
\text { orange }\end{array}$ & y, silt-grade; limestone, \\
\hline & 113 & to & 118 & $\begin{array}{l}\text { Limestone, very light g } \\
\text { calcareous }\end{array}$ & ay, silt-grade; shale, very \\
\hline & 118 & to & 120 & Limestone, very light g & ay, silt-grade \\
\hline & 120 & to & 121 & $\begin{array}{l}\text { Limestone, very light } \mathrm{g} \\
\text { gray }\end{array}$ & ay, silt-grade; shale, green- \\
\hline & 121 & to & 123 & Shale, green-gray & \\
\hline & 123 & to & 125 & Shale, very dark gray, & lty, blocky \\
\hline & 125 & to & 126 & Shale, gray, lumpy & \\
\hline & 126 & to & 129 & Shale, gray, sandy, calc & reous, lumpy \\
\hline & 129 & to & 130 & Limestone, gray, oolitic & \\
\hline
\end{tabular}


Table 1. Geologic logs of test holes and observation wells drilled in southwest Iowa, 1985-87--Continued

\begin{tabular}{|c|c|c|c|c|c|c|c|}
\hline \multirow{2}{*}{$\begin{array}{c}\begin{array}{c}\text { Southwest } \\
\text { Iowa study } \\
\text { identification } \\
\text { number } \\
\text { (fig. 1) }\end{array} \\
\text { SW32 }\end{array}$} & \multicolumn{2}{|c|}{$\begin{array}{l}\text { Geological } \\
\text { Survey Bureau } \\
\text { identification } \\
\text { number }\end{array}$} & \multicolumn{2}{|c|}{$\begin{array}{l}\text { Township- } \\
\text { range-section } \\
\text { identification } \\
\text { number }\end{array}$} & $\begin{array}{c}\text { Latitude-longitude } \\
\text { identification } \\
\text { number } \\
\text { (DDMMSS-DDDMMSS) } \\
\end{array}$ & $\begin{array}{l}\text { Land- } \\
\text { surface } \\
\text { altitude } \\
\text { (feet above } \\
\text { sea level) }\end{array}$ & County \\
\hline & $\mathbf{W}-$ & & & -40-04AAAA & $412505-0952629$ & $1,177 \mathrm{P}$ & Pottawattamie \\
\hline SW32 casing & & $\begin{array}{r}0 \\
335\end{array}$ & & $\begin{array}{l}335 \\
340\end{array}$ & Well screen & & \\
\hline $\begin{array}{l}\text { Stratigraphi } \\
\text { unit }\end{array}$ & \multicolumn{4}{|c|}{$\begin{array}{l}\text { Depth interval } \\
\text { (feet) }\end{array}$} & Description & & \\
\hline \multicolumn{2}{|c|}{ Quaternary deposits } & $\begin{array}{r}0 \\
6 \\
9 \\
16 \\
40 \\
44\end{array}$ & $\begin{array}{l}\text { to } \\
\text { to } \\
\text { to } \\
\text { to } \\
\text { to } \\
\text { to }\end{array}$ & $\begin{array}{r}6 \\
9 \\
16 \\
40 \\
44 \\
50\end{array}$ & \multicolumn{3}{|c|}{$\begin{array}{l}\text { Fill and topsoil (driller's log) } \\
\text { Clay, brown, silty } \\
\text { Silt, gray, very argillaceous } \\
\text { Silt, medium light yellow-gray, argillaceous } \\
\text { Clay, yellow-gray, silty, very sandy; gravel, till-like } \\
\text { Gravel, varicolored; sand, colorless, medium }\end{array}$} \\
\hline \multirow[t]{7}{*}{ Pleistocene } & eposits & $\begin{array}{r}50 \\
80 \\
180\end{array}$ & $\begin{array}{l}\text { to } \\
\text { to } \\
\text { to }\end{array}$ & $\begin{array}{r}80 \\
180 \\
220\end{array}$ & \multicolumn{3}{|c|}{$\begin{array}{l}\text { Till, olive-gray, unoxidized, unleached } \\
\text { Till, light olive-gray, unoxidized, unleached } \\
\text { Till, light olive-gray, unoxidized, unleached; gravel, } \\
\text { varicolored, dirty }\end{array}$} \\
\hline & & 220 & to & 240 & \multicolumn{3}{|c|}{$\begin{array}{l}\text { Till, light olive-gray, unoxidized, unleached, sandy, } \\
\text { gravelly }\end{array}$} \\
\hline & & 240 & to & 260 & \multicolumn{3}{|c|}{$\begin{array}{l}\text { Till, light olive-gray, unoxidized, unleached, sandy, } \\
\text { gravelly; gravel }\end{array}$} \\
\hline & & 260 & to & 300 & \multicolumn{3}{|c|}{$\begin{array}{l}\text { Till, light olive-gray, unoxidized, unleached, } \\
\text { gravelly }\end{array}$} \\
\hline & & 300 & to & 340 & \multirow{3}{*}{\multicolumn{3}{|c|}{$\begin{array}{l}\text { Till, gray, unoxidized, unleached, gravelly } \\
\text { Till, gray, unoxidized, unleached, very sandy } \\
\text { Till, gray, unoxidized, unleached, very sandy; sand, } \\
\text { colorless, coarse to fine; gravel, varicolored; } \\
\text { quartz, metamorphic, and limestone rocks } \\
\text { Gravel, varicolored, subrounded; igneous or } \\
\text { metamorphic and limestone rocks }\end{array}$}} \\
\hline & & $\begin{array}{l}340 \\
360\end{array}$ & & $\begin{array}{l}360 \\
372\end{array}$ & & & \\
\hline & & 372 & to & 375 & & & \\
\hline
\end{tabular}


Table 1. Geologic logs of test holes and observation wells drilled in southwest lowa, 1985-87--Continued

\begin{tabular}{|c|c|c|c|c|c|c|c|}
\hline $\begin{array}{l}\text { Southwest } \\
\text { Iowa study } \\
\text { identification } \\
\text { number } \\
\text { (fig. 1) }\end{array}$ & \multicolumn{2}{|c|}{$\begin{array}{l}\text { Geological } \\
\text { Survey Bureau } \\
\text { identification } \\
\text { number }\end{array}$} & & $\begin{array}{l}\text { Township- } \\
\text { inge-section } \\
\text { lentification } \\
\text { number }\end{array}$ & $\begin{array}{c}\text { Latitude-longitude } \\
\text { identification } \\
\text { number } \\
\text { (DDMMSS-DDDMMSS) }\end{array}$ & $\begin{array}{l}\text { Land- } \\
\text { surface } \\
\text { altitude } \\
\text { (feet above } \\
\text { sea level) }\end{array}$ & County \\
\hline SW33 & \multicolumn{2}{|c|}{ W-27753 } & \multicolumn{2}{|c|}{ 76-37-23DABB } & $412204-0950351$ & 1,142 & \multirow[t]{3}{*}{ Cass } \\
\hline SW33U casing & & $\begin{array}{r}0 \\
40\end{array}$ & & $\begin{array}{l}40 \\
45\end{array}$ & Well screen & & \\
\hline SW33L casing & & $\begin{array}{r}0 \\
60\end{array}$ & & $\begin{array}{l}60 \\
65\end{array}$ & Well screen & & \\
\hline $\begin{array}{c}\text { Stratigraphic } \\
\text { unit }\end{array}$ & \multicolumn{4}{|c|}{$\begin{array}{l}\text { Depth interval } \\
\quad \text { (feet) }\end{array}$} & Description & & \\
\hline \multicolumn{2}{|c|}{ Quaternary deposits } & $\begin{array}{r}0 \\
2 \\
12 \\
15 \\
\\
20 \\
22 \\
35 \\
42 \\
52\end{array}$ & $\begin{array}{l}\text { to } \\
\text { to } \\
\text { to } \\
\text { to } \\
\text { to } \\
\text { to } \\
\text { to } \\
\text { to } \\
\text { to }\end{array}$ & $\begin{array}{r}2 \\
12 \\
15 \\
20 \\
\\
22 \\
35 \\
42 \\
52 \\
54\end{array}$ & \multicolumn{3}{|c|}{$\begin{array}{l}\text { Topsoil (driller's log) } \\
\text { Silt, yellow, argillaceous } \\
\text { Silt, very light gray and orange, very arg } \\
\text { Sand, colorless, orange, dark coarse to fi } \\
\text { partly with argillaceous cement } \\
\text { Silt, gray and yellow, very argillaceous } \\
\text { Silt, gray, with trace hard sand } \\
\text { Gravel, colorless, varicolored; sand, fine } \\
\text { Silt, gray, argillaceous, calcareous } \\
\text { Silt, medium dark gray, argillaceous }\end{array}$} \\
\hline Pleistocene d & leposits & $\begin{array}{l}54 \\
59\end{array}$ & $\begin{array}{l}\text { to } \\
\text { to }\end{array}$ & $\begin{array}{l}59 \\
66\end{array}$ & \multicolumn{3}{|c|}{$\begin{array}{l}\text { Till, gray, unoxidized, unleached } \\
\text { Sand, colorless, yellow, coarse to medium; } \\
\text { gravel, quartz, trace igneous, granite; gravel, } \\
\text { light gray, silt-grade, limestone rocks }\end{array}$} \\
\hline $\begin{array}{l}\text { Pennsylvanian } \\
\text { undifferentia }\end{array}$ & $\begin{array}{l}\text { rocks, } \\
\text { ted }\end{array}$ & 66 & to & 68 & \multicolumn{3}{|c|}{ Limestone, light gray, silt-grade, Kansas City Group } \\
\hline $\begin{array}{l}\text { Southwest } \\
\text { Iowa study } \\
\text { identification } \\
\text { number } \\
\text { (fig. 1) }\end{array}$ & \multicolumn{2}{|c|}{$\begin{array}{l}\text { Geological } \\
\text { Survey Bureau } \\
\text { identification } \\
\text { number }\end{array}$} & \multicolumn{2}{|c|}{$\begin{array}{l}\text { Township- } \\
\text { range-section } \\
\text { identification } \\
\text { number }\end{array}$} & $\begin{array}{c}\text { Latitude-longitude } \\
\text { identification } \\
\text { number } \\
\text { (DDMMSS-DDDMMSS) }\end{array}$ & $\begin{array}{l}\text { Land- } \\
\text { surface } \\
\text { altitude } \\
\text { (feet above } \\
\text { sea level) }\end{array}$ & County \\
\hline SW34 & \multicolumn{2}{|c|}{ W-27834 } & \multicolumn{2}{|c|}{ 74-38-36BAAA } & $411025-0950956$ & $1,073 \mathrm{Pc}$ & awattamie \\
\hline SW34U casing & & $\begin{array}{r}0 \\
20\end{array}$ & $\begin{array}{l}\text { to } \\
\text { to }\end{array}$ & $\begin{array}{l}20 \\
25\end{array}$ & Well screen & & \\
\hline SW34L casing & & $\begin{array}{r}0 \\
34\end{array}$ & $\begin{array}{l}\text { to } \\
\text { to }\end{array}$ & $\begin{array}{l}34 \\
39\end{array}$ & Well screen & & \\
\hline
\end{tabular}


Table 1. Geologic logs of test holes and observation wells drilled in southwest Iowa, 1985-87--Continued

Stratigraphic
unit

sW34--Continued

\section{Depth interval} (feet)
Description

Quaternary deposits

$\begin{array}{rlr}\mathbf{0} & \text { to } & \mathbf{3} \\ \mathbf{3} & \text { to } & \mathbf{5} \\ \mathbf{5} & \text { to } & \mathbf{9} \\ \mathbf{9} & \text { to } & 11 \\ 11 & \text { to } & 15 \\ 15 & \text { to } & 18 \\ & & \\ 18 & \text { to } & 24\end{array}$

Fill and topsoil (driller's log)

Clay, dark gray (driller's log)

Clay, gray, yellow-gray, silty

Silt, orange, argillaceous

Silt, gray, yellow-gray, argillaceous

Sand, colorless, yellow, orange, dark, medium to fine and coarse, quartz

Sand, colorless, yellow, orange, dark, medium to fine and coarse, quartz; gravel, partly argillaceous

Gravel; sand, colorless, yellow, orange, dark, medium to fine and coarse, quartz

Sand, colorless, yellow, orange, dark, medium to fine and coarse, quartz; gravel

Sandstone; gravel; dolostone; very light gray, siltgrade

Gravel, igneous and dolostone rocks; sand

$\begin{array}{lll}\text { Cretaceous rocks } & 60 & \text { to } \\ & 100\end{array}$

Dakota Formation $\quad 100$ to 101

Sandstone, colorless, orange, medium to coarse and fine, quartz

Sandstone, yellow-brown and tan, fine to medium (driller's log)

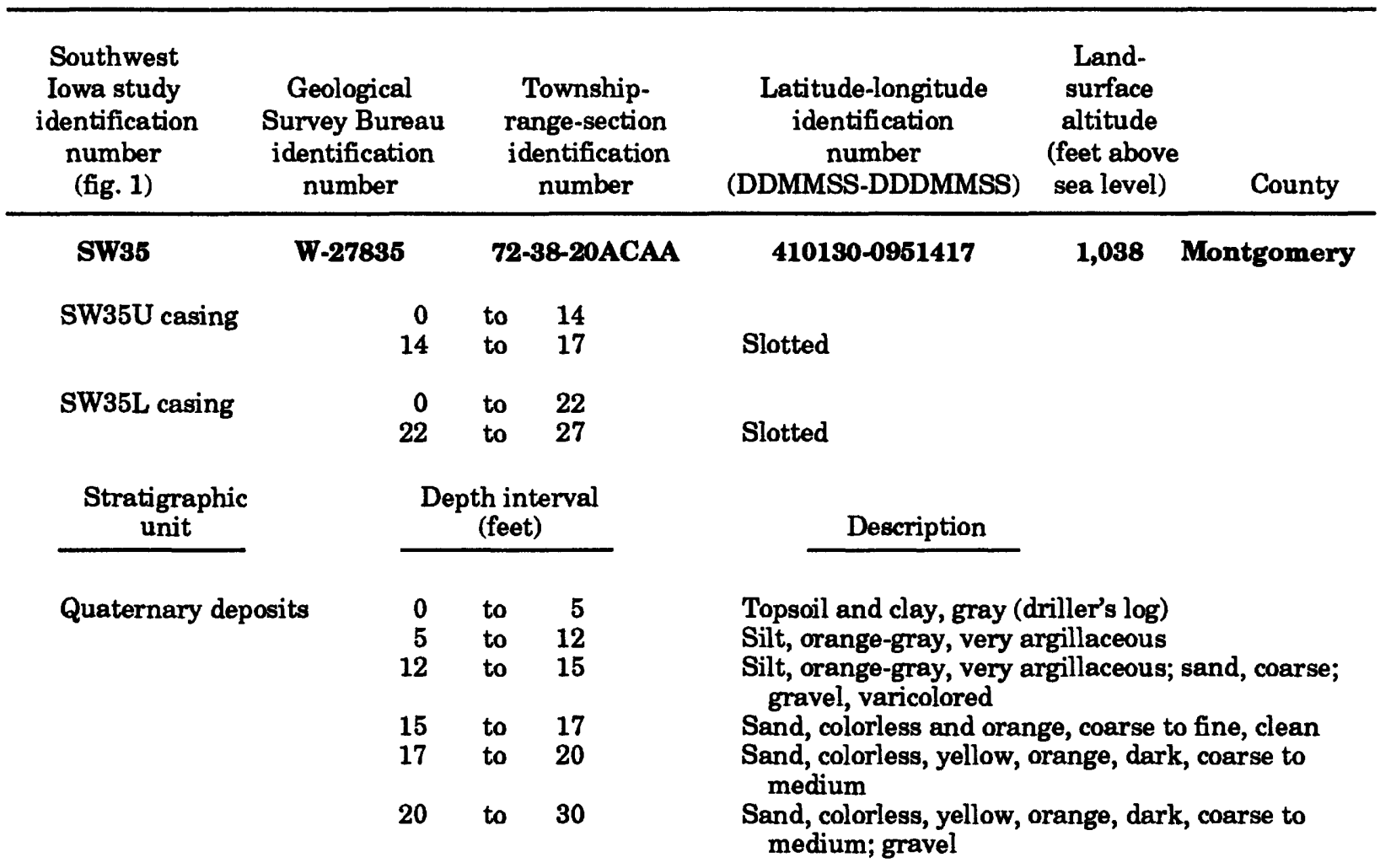


Table 1. Geologic logs of test holes and observation wells drilled in southwest Iowa, 1985-87--Continued

\begin{tabular}{|c|c|c|c|c|c|c|c|}
\hline \multirow{3}{*}{\multicolumn{2}{|c|}{$\begin{array}{l}\begin{array}{c}\text { Stratigraphic } \\
\text { unit }\end{array} \\
\text { SW35--Continued } \\
\text { Pennsylvanian rocks, } \\
\text { undifferentiated } \\
\text { Virgil Series }\end{array}$}} & \multicolumn{3}{|c|}{$\begin{array}{c}\begin{array}{c}\text { Depth interval } \\
\text { (feet) }\end{array} \\
\end{array}$} & Description & \\
\hline & & \multirow[b]{2}{*}{30} & \multirow{2}{*}{\multicolumn{2}{|c|}{ to 33}} & \multirow[b]{2}{*}{ Limestone, brown to yellow, with iron oxide } & & \\
\hline & & & & & & & \\
\hline $\begin{array}{l}\text { Southwest } \\
\text { Iowa study } \\
\text { identification } \\
\text { number } \\
\text { (fig. 1) }\end{array}$ & $\begin{array}{r}\text { Gec } \\
\text { Surve } \\
\text { iden } \\
\text { no }\end{array}$ & $\begin{array}{l}\text { cal } \\
\text { ureau } \\
\text { tion } \\
\text { r }\end{array}$ & \multicolumn{2}{|c|}{$\begin{array}{l}\text { Township- } \\
\text { range-section } \\
\text { identification } \\
\text { number }\end{array}$} & $\begin{array}{c}\text { Latitude-longitude } \\
\text { identification } \\
\text { number } \\
\text { (DDMMSS-DDDMMSS) }\end{array}$ & $\begin{array}{c}\text { Land- } \\
\text { surface } \\
\text { altitude } \\
\text { (feet above } \\
\text { sea level) } \\
\end{array}$ & County \\
\hline SW36 & \multicolumn{2}{|c|}{ W-27836 } & \multicolumn{2}{|c|}{ 71-41-04AAAA } & $405911-0953324$ & 977 & Mills \\
\hline SW36U casing & & $\begin{array}{r}0 \\
40\end{array}$ & & $\begin{array}{l}40 \\
44\end{array}$ & Slotted & & \\
\hline SW36L casing & & $\begin{array}{r}0 \\
57\end{array}$ & & $\begin{array}{l}57 \\
62\end{array}$ & Well screen & & \\
\hline $\begin{array}{c}\text { Stratigraphi } \\
\text { unit }\end{array}$ & & \multicolumn{3}{|c|}{$\begin{array}{l}\text { Depth interval } \\
\quad \text { (feet) }\end{array}$} & Description & & \\
\hline \multicolumn{2}{|c|}{ Quaternary deposits } & $\begin{array}{r}0 \\
3 \\
5 \\
8 \\
16 \\
20 \\
27 \\
29 \\
30 \\
32 \\
40 \\
50 \\
\end{array}$ & $\begin{array}{l}\text { to } \\
\text { to } \\
\text { to } \\
\text { to } \\
\text { to } \\
\text { to } \\
\text { to } \\
\text { to } \\
\text { to } \\
\text { to } \\
\text { to } \\
\text { to } \\
\text { to }\end{array}$ & $\begin{array}{r}3 \\
5 \\
8 \\
16 \\
20 \\
27 \\
29 \\
30 \\
32 \\
40 \\
50 \\
\\
68\end{array}$ & \multicolumn{3}{|c|}{$\begin{array}{l}\text { Topsoil (driller's log) } \\
\text { Clay, yellow-gray, silty (driller's log) } \\
\text { Silt, pale yellow, very argillaceous } \\
\text { Silt, orange, very argillaceous } \\
\text { Silt, orange, very argillaceous, calcareous } \\
\text { Silt, very pale yellow, very argillaceous, calcareous } \\
\text { Silt, brown-gray, argillaceous } \\
\text { Sand, colorless and dark coarse to fine; gravel } \\
\text { Silt, gray, very argillaceous, slightly sandy } \\
\text { Clay, gray, silty } \\
\text { Sand, colorless and very light gray, coarse to fine, } \\
\text { subrounded to angular } \\
\text { Gravel, varicolored; sand, colorless and very light } \\
\text { gray, coarse to fine, subrounded to angular } \\
\text { Clay, dark orange and brown, gravelly, sandy }\end{array}$} \\
\hline $\begin{array}{l}\text { Southwest } \\
\text { Iowa study } \\
\text { identification } \\
\text { number } \\
\text { (fig. 1) }\end{array}$ & \multicolumn{2}{|c|}{$\begin{array}{l}\text { Geological } \\
\text { Survey Bureau } \\
\text { identification } \\
\text { number }\end{array}$} & \multicolumn{2}{|c|}{$\begin{array}{l}\text { Township- } \\
\text { range-section } \\
\text { identification } \\
\text { number }\end{array}$} & $\begin{array}{c}\text { Latitude-longitude } \\
\text { identification } \\
\text { number } \\
\text { (DDMMSS-DDDMMSS) }\end{array}$ & $\begin{array}{l}\text { Land- } \\
\text { surface } \\
\text { altitude } \\
\text { (feet above } \\
\text { sea level) }\end{array}$ & County \\
\hline SW37 & \multicolumn{2}{|c|}{ W-27837 } & \multicolumn{2}{|c|}{ 73-41-23BCCC } & $410636-0953215$ & 1,068 & Mills \\
\hline SW37 casing & & $\begin{array}{r}0 \\
255\end{array}$ & & $\begin{array}{l}255 \\
260\end{array}$ & Well screen & & \\
\hline
\end{tabular}


Table 1. Geologic logs of test holes and observation wells drilled in southwest Iowa, 1985-87--Continued

\begin{tabular}{|c|c|c|c|c|c|c|c|}
\hline \multicolumn{2}{|c|}{$\begin{array}{c}\text { Stratigraphic } \\
\text { unit }\end{array}$} & \multicolumn{3}{|c|}{$\begin{array}{c}\text { Depth interval } \\
\text { (feet) }\end{array}$} & \multicolumn{3}{|l|}{ Description } \\
\hline \multicolumn{8}{|c|}{ SW37-.Continued } \\
\hline \multirow{2}{*}{\multicolumn{2}{|c|}{ Quaternary deposits }} & 0 & to & 2 & Topsoil (driller's log) & & \\
\hline & & $\begin{array}{l}2 \\
8\end{array}$ & $\begin{array}{l}\text { to } \\
\text { to }\end{array}$ & $\begin{array}{r}8 \\
12\end{array}$ & $\begin{array}{l}\text { Clay, gray, silty } \\
\text { Silt, orange, argillaceou }\end{array}$ & & \\
\hline \multirow{9}{*}{\multicolumn{2}{|c|}{ Pleistocene deposits }} & $\begin{array}{l}12 \\
20 \\
24 \\
32 \\
36\end{array}$ & & $\begin{array}{l}20 \\
24 \\
32 \\
36 \\
40\end{array}$ & $\begin{array}{l}\text { Till, yellow, oxidized, ur } \\
\text { Till, light gray, unoxidi } \\
\text { Till, pale yellow, oxidize } \\
\text { Till, medium light gray, } \\
\text { Till, medium light gray }\end{array}$ & $\begin{array}{l}\text { nleached } \\
\text { zed, unleache } \\
\text { ed, unleached } \\
\text { unoxidized, } \\
\text { unoxidized, }\end{array}$ & $\begin{array}{l}\text { unleached } \\
\text { unleached, }\end{array}$ \\
\hline & & $\begin{array}{l}40 \\
50\end{array}$ & & $\begin{array}{l}50 \\
60\end{array}$ & $\begin{array}{l}\text { with sparse sand } \\
\text { Till, light olive-gray, un } \\
\text { Sand, varicolored, color } \\
\text { subrounded, partly ve }\end{array}$ & $\begin{array}{l}\text { loxidized, unl } \\
\text { less, coarse to } \\
\text { ery argillaceo }\end{array}$ & $\begin{array}{l}\text { eached } \\
\text { fine; gravel, } \\
\text { as }\end{array}$ \\
\hline & & 60 & to & 80 & $\begin{array}{l}\text { Till, light olive-gray, un } \\
\text { sandy }\end{array}$ & loxidized, unl & ached, very \\
\hline & & 80 & & 100 & Till, light olive-gray, un & oxidized, unl & ached \\
\hline & & 100 & to & 134 & $\begin{array}{l}\text { Till, light olive-gray, un } \\
\text { gravelly }\end{array}$ & loxidized, unl & eached, very \\
\hline & & 134 & to & 170 & $\begin{array}{l}\text { Gravel, varicolored, sub } \\
\text { metamorphic and lim } \\
\text { light olive-gray, unox } \\
\text { very gravelly }\end{array}$ & $\begin{array}{l}\text { rounded; qua } \\
\text { estone rocks; } \\
\text { idized, unleac }\end{array}$ & $\begin{array}{l}\text { rtz; } \\
\text { till, } \\
\text { hed, }\end{array}$ \\
\hline & & 170 & to & 175 & $\begin{array}{l}\text { Gravel, varicolored, sub } \\
\text { metamorphic and lim }\end{array}$ & $\begin{array}{l}\text { rounded, qua } \\
\text { estone rocks }\end{array}$ & \\
\hline & & 175 & to & 239 & $\begin{array}{l}\text { Till, light olive-gray, un } \\
\text { varicolored, subround } \\
\text { and limestone rocks }\end{array}$ & $\begin{array}{l}\text { loxidized, unl } \\
\text { led; quartz, m }\end{array}$ & $\begin{array}{l}\text { ached; gravel, } \\
\text { etamorphic, }\end{array}$ \\
\hline & & 239 & to & 279 & $\begin{array}{l}\text { Sand, colorless, varicolo } \\
\text { with } 10 \text { percent dark } \\
\text { to subangular }\end{array}$ & $\begin{array}{l}\text { red, coarse to } \\
\text { grains; grave }\end{array}$ & $\begin{array}{l}\text { fine, quartz, } \\
\text {, subrounded }\end{array}$ \\
\hline \multicolumn{2}{|c|}{$\begin{array}{l}\text { Pennsylvanian rocks, } \\
\text { undifferentiated }\end{array}$} & 279 & to & 285 & Shale, gray-green (drill & er's log) & \\
\hline $\begin{array}{c}\text { Southwest } \\
\text { Iowa study } \\
\text { identification } \\
\text { number } \\
\text { (fig. 1) }\end{array}$ & \multicolumn{2}{|c|}{$\begin{array}{l}\text { Geological } \\
\text { Survey Bureau } \\
\text { identification } \\
\text { number }\end{array}$} & \multicolumn{2}{|c|}{$\begin{array}{l}\text { Township- } \\
\text { range-section } \\
\text { identification } \\
\text { number }\end{array}$} & $\begin{array}{c}\text { Latitude-longitude } \\
\text { identification } \\
\text { number }\end{array}$ & $\begin{array}{c}\text { Land- } \\
\text { surface } \\
\text { altitude } \\
\text { (feet above } \\
\text { sea level) } \\
\end{array}$ & County \\
\hline SW38 & \multicolumn{2}{|c|}{ W-27839 } & \multicolumn{2}{|c|}{ 70-41-32AABB } & $404906-0953446$ & 960 & Fremont \\
\hline \multicolumn{2}{|l|}{ SW38U casing } & $\begin{array}{r}0 \\
35\end{array}$ & $\begin{array}{l}\text { to } \\
\text { to }\end{array}$ & $\begin{array}{l}35 \\
38\end{array}$ & Slotted & & \\
\hline \multicolumn{2}{|l|}{ SW38L casing } & $\begin{array}{r}0 \\
50\end{array}$ & $\begin{array}{l}\text { to } \\
\text { to }\end{array}$ & $\begin{array}{l}50 \\
55\end{array}$ & Well screen & & \\
\hline
\end{tabular}


Table 1. Geologic logs of test holes and observation wells drilled in southwest Iowa, 1985-87-.Continued

\begin{tabular}{lrrr}
\hline $\begin{array}{c}\text { Stratigraphic } \\
\text { unit }\end{array}$ & \multicolumn{3}{c}{$\begin{array}{c}\text { Depth interval } \\
\text { (feet) }\end{array}$} \\
\hline SW38--Continued & & & \\
Quaternary deposits & 0 & to & 2 \\
& 2 & to & 5 \\
& & 5 & to \\
& 17 & to & 20 \\
& 20 & to & 26 \\
& 26 & to & 30 \\
& 30 & to & 32 \\
& 32 & to & 34 \\
& & & \\
& 34 & to & 40 \\
& 40 & to & 56
\end{tabular}

Pleistocene deposits $\quad 56 \quad$ to 58

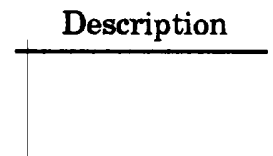

Topsoil (driller's log)

Clay, yellow-brown, silty (driller's log)

17Silt, yellow, argillaceous

Silt, yellow, argillaceous, calcareous

Silt, orange, very light gray, argillaceous, calcareous

Clay, very light gray, calcareous, silty

Clay, very light gray, calcareous, silty; silt, argillaceous

Clay, very light gray, calcareous, silty; silt, orange, argillaceous; sand, colorless, coarse to fine

Sand, colorless, varicolored, coarse to fine; gravel

Sand, colorless, varicolored, coarse to fine; gravel, subrounded to subangular

Gravel, gray; till, gray unoxidized, leached

\begin{tabular}{|c|c|c|c|c|c|c|}
\hline $\begin{array}{l}\text { Southwest } \\
\text { Iowa study } \\
\text { identification } \\
\text { number } \\
\text { (fig. 1) }\end{array}$ & $\begin{array}{c}\text { Geological } \\
\text { Survey Bureau } \\
\text { identification } \\
\text { number }\end{array}$ & \multicolumn{2}{|c|}{$\begin{array}{l}\text { Township- } \\
\text { range-section } \\
\text { identification } \\
\text { number }\end{array}$} & $\begin{array}{c}\text { Latitude-longitude } \\
\text { identification } \\
\text { number } \\
\text { (DDMMSS-DDDMMSS) }\end{array}$ & $\begin{array}{l}\text { Land- } \\
\text { surface } \\
\text { altitude } \\
\text { (feet above } \\
\text { sea level) } \\
\end{array}$ & County \\
\hline SW39 & W-27840 & \multicolumn{2}{|c|}{ 70-41-32AABB } & $404906-0953446$ & $\mathbf{9 6 0}$ & Fremont \\
\hline SW39U casing & $\begin{array}{r}0 \\
130\end{array}$ & & $\begin{array}{l}130 \\
135\end{array}$ & \multicolumn{3}{|c|}{ 2-inch diameter polyvinyl-chloride well screen } \\
\hline SW39L casing & $\begin{array}{r}0 \\
216\end{array}$ & & $\begin{array}{l}216 \\
221\end{array}$ & \multicolumn{3}{|c|}{ 2-inch diameter polyvinyl-chloride well screen } \\
\hline $\begin{array}{c}\text { Stratigraphic } \\
\text { unit }\end{array}$ & \multicolumn{3}{|c|}{$\begin{array}{l}\text { Depth interval } \\
\text { (feet) }\end{array}$} & Description & & \\
\hline Quaternary deposits & 0 & to & 56 & \multicolumn{3}{|c|}{ No samples (see log for SW38) } \\
\hline \multirow[t]{5}{*}{ Pleistocene deposits } & 56 & to & 60 & \multirow{5}{*}{\multicolumn{3}{|c|}{$\begin{array}{l}\text { Till, olive-gray, unoxidized, unleached, weakly } \\
\text { calcareous } \\
\text { Till, olive-gray, unoxidized, unleached } \\
\text { Till, gray, unoxidized, unleached } \\
\text { Till, gray, unoxidized, unleached, gravelly } \\
\text { Till, light olive-gray, unoxidized, unleached }\end{array}$}} \\
\hline & 60 & to & 100 & & & \\
\hline & 100 & to & 119 & & & \\
\hline & 119 & to & 121 & & & \\
\hline & 121 & to & 125 & & & \\
\hline \multirow{3}{*}{$\begin{array}{l}\text { Tertiary deposits } \\
\text { Pliocene deposits }\end{array}$} & & & & & & \\
\hline & 125 & to & 140 & \multirow{2}{*}{\multicolumn{3}{|c|}{$\begin{array}{l}\text { Sand, colorless, yellow, orange, dark medium to } \\
\text { fine and coarse, subrounded, quartz, with } 5 \\
\text { percent heavy, igneous or metamorphic grains } \\
\text { Sand, colorless, yellow, orange, dark coarse to } \\
\text { fine, quartz, with trace heavy minerals }\end{array}$}} \\
\hline & 140 & to & 160 & & & \\
\hline
\end{tabular}


Table 1. Geologic logs of test holes and observation wells drilled in southwest Iowa, 1985-87--Continued

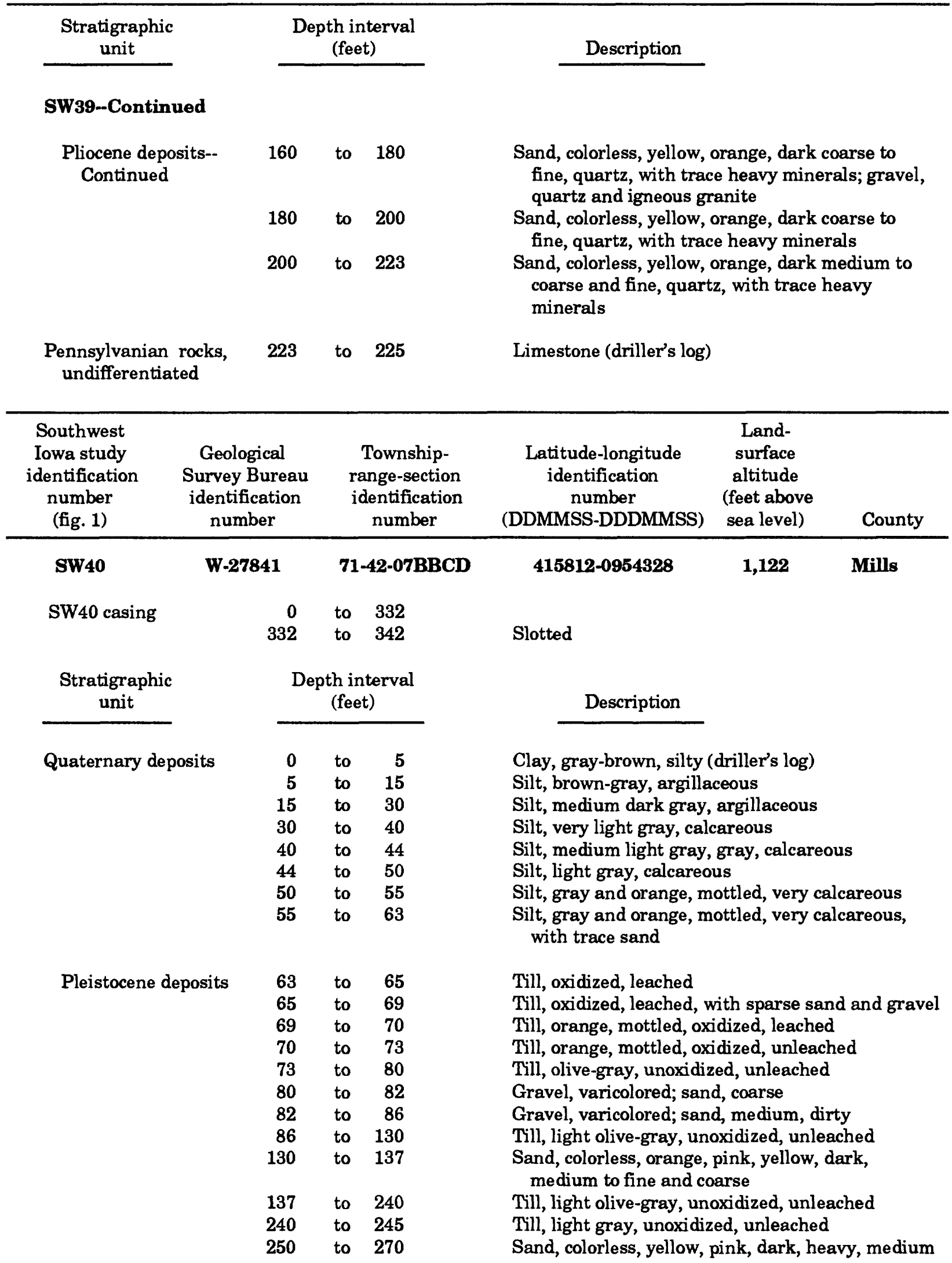


Table 1. Geologic logs of test holes and observation wells drilled in southwest Iowa, 1985-87--Continued

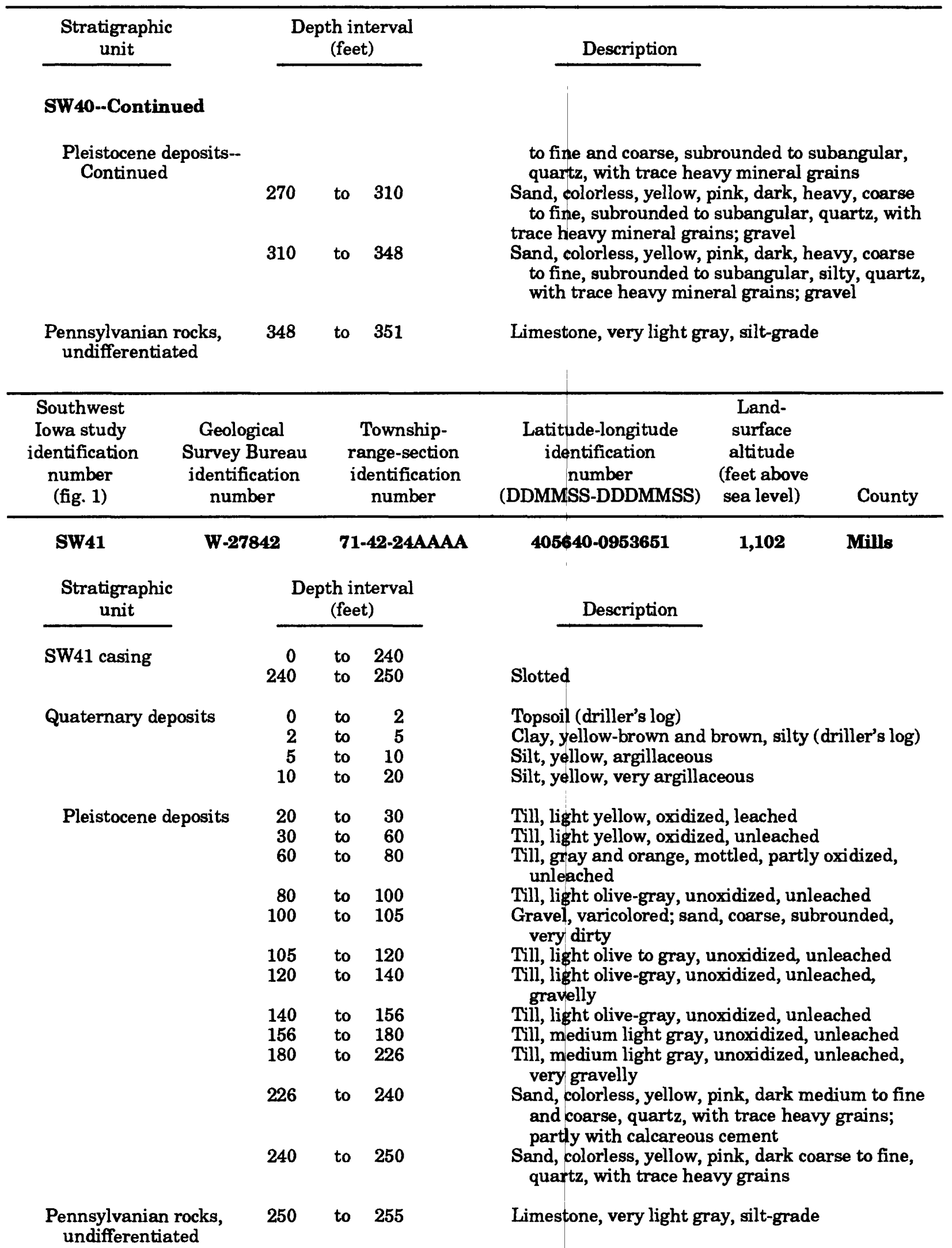


Table 1. Geologic logs of test holes and observation wells drilled in southwest Iowa, 1985-87--Continued

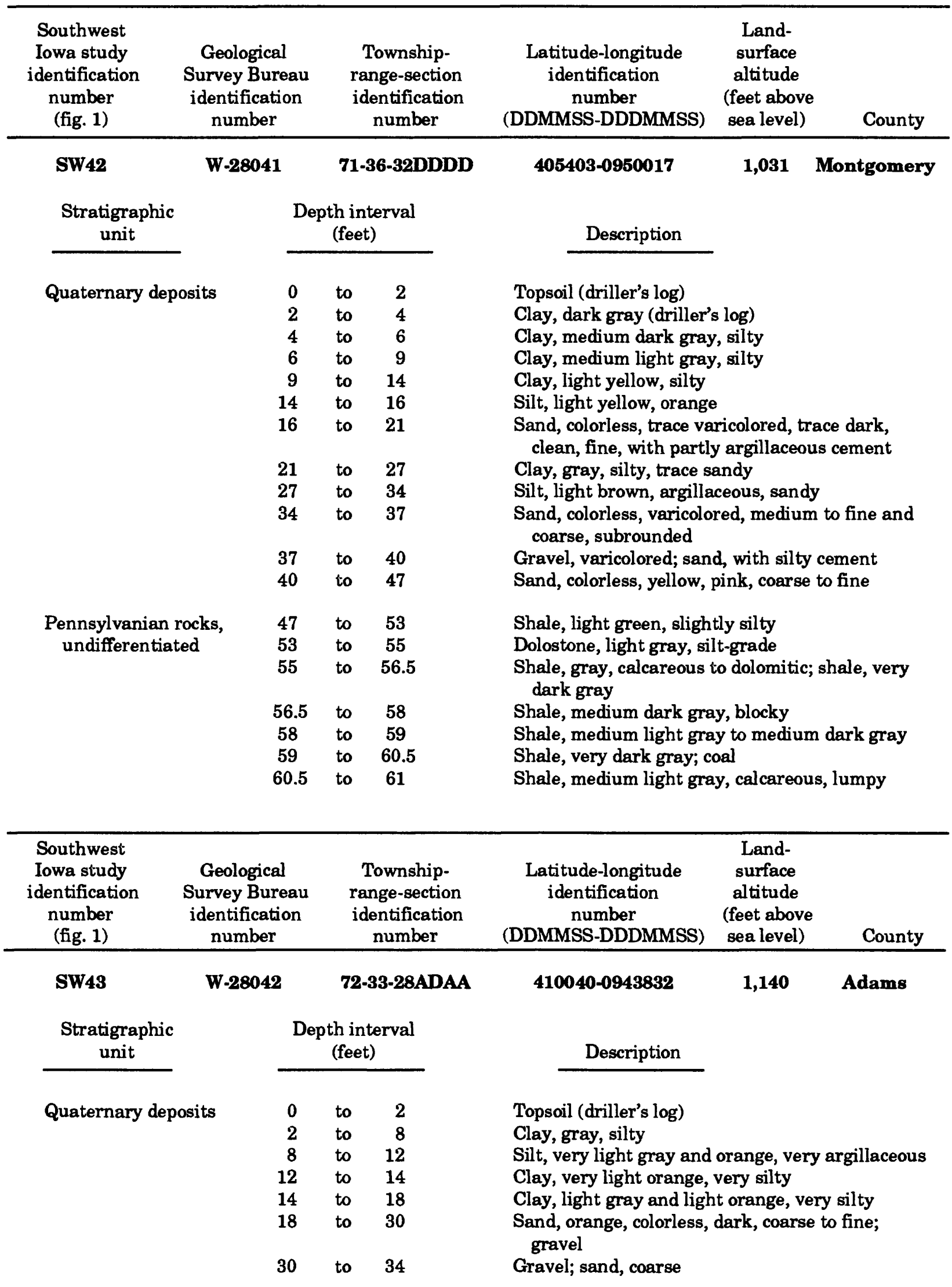


Table 1. Geologic logs of test holes and observation wells drilled in southwest lowa, 1985-87--Continued

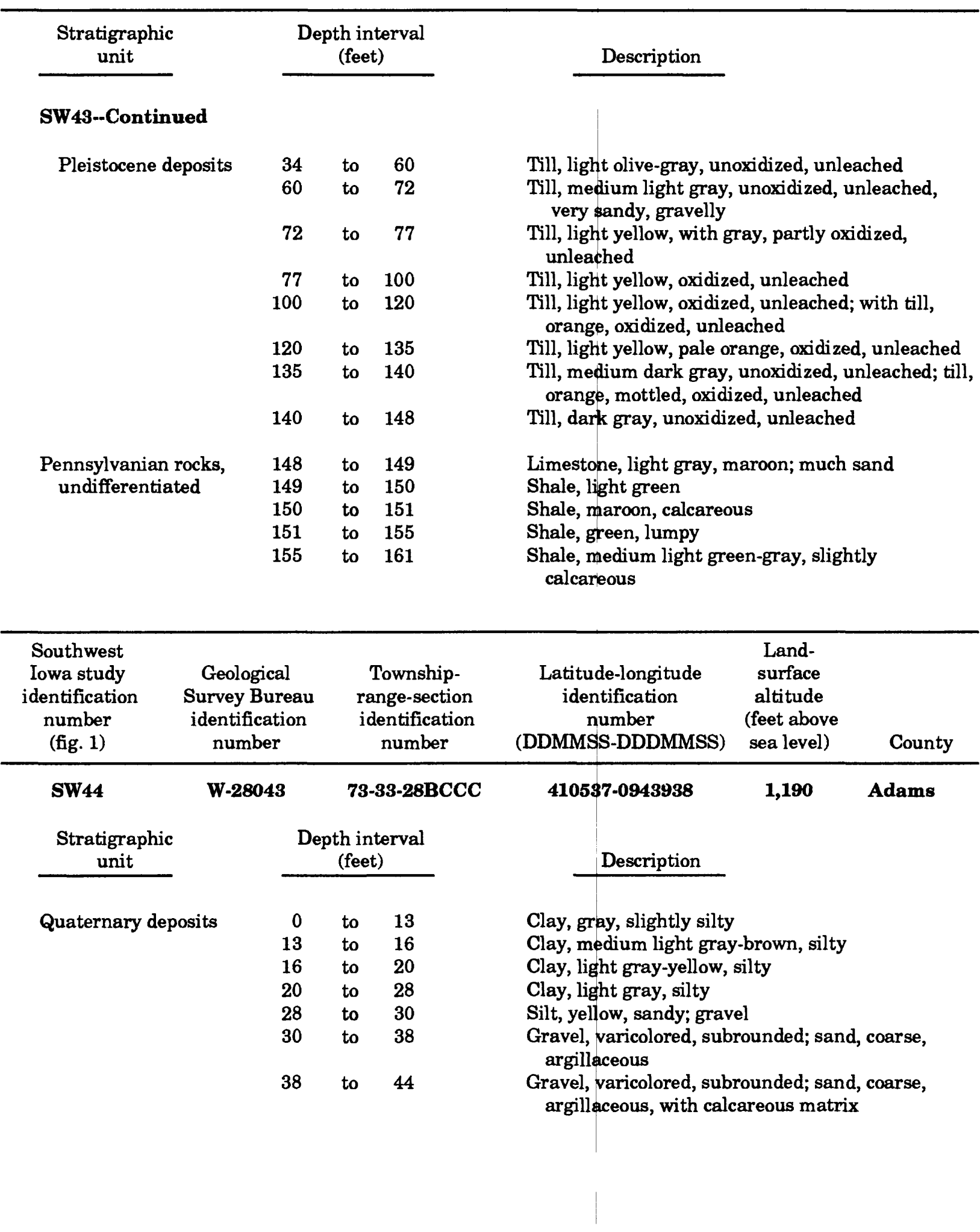


Table 1. Geologic logs of test holes and observation wells drilled in southwest Iowa, 1985-87--Continued

\begin{tabular}{|c|c|c|c|}
\hline $\begin{array}{l}\text { Stratigraphic } \\
\text { unit }\end{array}$ & \multicolumn{3}{|c|}{$\begin{array}{l}\text { Depth interval } \\
\text { (feet) }\end{array}$} \\
\hline \multicolumn{4}{|l|}{ SW44--Continued } \\
\hline \multirow[t]{4}{*}{ Pleistocene deposits } & $\begin{array}{l}44 \\
50 \\
80\end{array}$ & $\begin{array}{l}\text { to } \\
\text { to } \\
\text { to }\end{array}$ & $\begin{array}{l}50 \\
80 \\
90\end{array}$ \\
\hline & $\begin{array}{r}90 \\
130 \\
140 \\
151\end{array}$ & $\begin{array}{l}\text { to } \\
\text { to } \\
\text { to } \\
\text { to }\end{array}$ & $\begin{array}{l}130 \\
140 \\
151 \\
155\end{array}$ \\
\hline & $\begin{array}{l}155 \\
178\end{array}$ & $\begin{array}{l}\text { to } \\
\text { to }\end{array}$ & $\begin{array}{l}178 \\
180\end{array}$ \\
\hline & $\begin{array}{l}180 \\
187\end{array}$ & $\begin{array}{l}\text { to } \\
\text { to }\end{array}$ & $\begin{array}{l}187 \\
197\end{array}$ \\
\hline \multirow{3}{*}{$\begin{array}{l}\text { Pennsylvanian rocks, } \\
\text { undifferentiated }\end{array}$} & 197 & to & 199 \\
\hline & $\begin{array}{l}199 \\
205 \\
207\end{array}$ & $\begin{array}{l}\text { to } \\
\text { to } \\
\text { to }\end{array}$ & $\begin{array}{l}205 \\
207 \\
208\end{array}$ \\
\hline & 208 & to & 212 \\
\hline
\end{tabular}


Table 1. Geologic logs of test holes and observation wells drilled in southwest Iowa, 1985-87--Continued

\begin{tabular}{|c|c|c|c|c|}
\hline $\begin{array}{l}\text { Stratigraphic } \\
\text { unit }\end{array}$ & \multicolumn{3}{|c|}{$\begin{array}{c}\text { Depth interval } \\
\text { (feet) }\end{array}$} & \multirow[t]{2}{*}{ Description } \\
\hline \multicolumn{4}{|l|}{ SW45--Continued } & \\
\hline \multirow[t]{2}{*}{$\begin{array}{l}\text { Quaternary deposits-- } \\
\text { Continued }\end{array}$} & 20 & to & 25 & $\begin{array}{l}\text { Sand, colorless, varicolored, coarse to fine, } \\
\text { subrounded; gravel, fine, subrounded, with } \\
\text { argillaceous matrix }\end{array}$ \\
\hline & 25 & to & 29 & $\begin{array}{l}\text { Sand, colorless, varicolored, coarse to fine, } \\
\text { subrounded; gravel, fine, subrounded, with } \\
\text { slightly argillaceous matrix }\end{array}$ \\
\hline \multirow[t]{3}{*}{ Pleistocene deposits } & 29 & to & 40 & Till, blue-gray (driller's log) \\
\hline & 40 & to & 48 & Till, medium light gray, unoxidized, unleached \\
\hline & 48 & to & 50 & Gravel, varicolored, subrounded; sand, coarse \\
\hline \multirow[t]{22}{*}{$\begin{array}{l}\text { Pennsylvanian rocks, } \\
\text { undifferentiated }\end{array}$} & 50 & to & 54 & $\begin{array}{l}\text { Shale, light green and yellow, lumpy, soft, } \\
\text { calcareous }\end{array}$ \\
\hline & 54 & to & 55 & Shale, gray, lumpy, hard, calcareous \\
\hline & 55 & to & 57 & Dolostone, light gray, silt-grade, calcareous \\
\hline & 57 & to & 59 & Shale, light green, lumpy, calcareous \\
\hline & 59 & to & 60 & $\begin{array}{l}\text { Siltstone, yellow, calcareous; shale, green, } \\
\text { lumpy, calcareous }\end{array}$ \\
\hline & 60 & to & 61 & $\begin{array}{l}\text { Limestone, very light yellow, silt-grade; shale, } \\
\text { light green }\end{array}$ \\
\hline & 61 & to & 63 & Shale, green, calcareous, lumpy \\
\hline & 63 & to & 65 & Limestone, very light gray, silt-grade to fine, dense \\
\hline & 65 & to & 68 & Shale, very light green-gray, silty, calcareous \\
\hline & 68 & to & 69 & $\begin{array}{l}\text { Shale, very light green-gray, silty, calcareous; } \\
\text { limestone }\end{array}$ \\
\hline & 69 & to & 70 & Shale; limestone; shale, dark gray, subflaky \\
\hline & 70 & to & 72.5 & Shale, dark gray, silty, calcareous \\
\hline & 72.5 & to & 75 & Shale, light green, silty, calcareous \\
\hline & 75 & to & 76 & $\begin{array}{l}\text { Dolostone, very light gray, silt-grade, argillaceous; } \\
\text { shale, light green, silty, calcareous }\end{array}$ \\
\hline & 76 & to & 78 & $\begin{array}{l}\text { Limestone, very light gray, argillaceous; shale, light } \\
\text { green, silty, calcareous }\end{array}$ \\
\hline & 78 & to & 79 & $\begin{array}{l}\text { Limestone, very light gray, silt-grade; shale, dark } \\
\text { gray. }\end{array}$ \\
\hline & 79 & to & 80 & $\begin{array}{l}\text { Limestone, very light gray, fine to silt-grade, } \\
\text { crystalline }\end{array}$ \\
\hline & 80 & to & 81 & $\begin{array}{l}\text { Limestone, very light gray, fine to silt-grade, } \\
\text { crystalline, dolomitic }\end{array}$ \\
\hline & 81 & to & 83 & Limestone, very light gray, silt-grade \\
\hline & 83 & to & 85 & Dolostone, medium light gray, argillaceous \\
\hline & 85 & to & 87 & $\begin{array}{l}\text { Limestone, medium light gray, silt-grade, } \\
\text { argillaceous }\end{array}$ \\
\hline & 87 & to & 95 & Shale, medium dark gray, silty, calcareous \\
\hline
\end{tabular}


Table 1. Geologic logs of test holes and observation wells drilled in southwest Iowa, 1985-87--Continued

\begin{tabular}{|c|c|c|c|c|c|c|c|}
\hline \multirow[t]{2}{*}{$\begin{array}{l}\text { Southwest } \\
\text { Iowa study } \\
\text { identification } \\
\text { number } \\
\text { (fig. 1) }\end{array}$} & \multicolumn{2}{|c|}{$\begin{array}{c}\text { Geological } \\
\text { Survey Bureau } \\
\text { identification } \\
\text { number }\end{array}$} & \multicolumn{2}{|c|}{$\begin{array}{l}\text { Township- } \\
\text { range-section } \\
\text { identification } \\
\text { number }\end{array}$} & $\begin{array}{c}\text { Latitude-longitude } \\
\text { identification } \\
\text { number } \\
\text { (DDMMSS-DDDMMSS) }\end{array}$ & \multirow{2}{*}{$\begin{array}{c}\begin{array}{c}\text { Land } \\
\text { surface } \\
\text { altitude } \\
\text { (feet above } \\
\text { sea level) }\end{array} \\
\mathbf{1 , 2 2 7}\end{array}$} & \multirow{2}{*}{$\frac{\text { County }}{\text { Adair }}$} \\
\hline & $\mathbf{W}-2$ & & & $33-20 C C C C$ & $412136-0944049$ & & \\
\hline \multirow[t]{2}{*}{$\begin{array}{c}\text { Stratigrap } \\
\text { unit }\end{array}$} & & \multicolumn{3}{|c|}{$\begin{array}{l}\text { Depth interval } \\
\text { (feet) }\end{array}$} & Description & & \\
\hline & & 0 & to & 5 & Roadbed and fill (driller & s log) & \\
\hline \multirow{7}{*}{\multicolumn{2}{|c|}{ Quaternary deposits }} & 5 & to & 13 & Clay, medium light brov & $\mathrm{m}$, silty & \\
\hline & & 13 & to & 14 & Clay, orange-brown, silt & & \\
\hline & & 14 & to & 19 & Clay, gray with orange & nottling, harc & \\
\hline & & 19 & to & 21 & Clay, gray, orange to ye & low, silty, sar & \\
\hline & & 21 & to & 30 & $\begin{array}{l}\text { Gravel; sand, varicolore } \\
\text { partly with argillaceo }\end{array}$ & $\begin{array}{l}\text { d, subroundec } \\
\text { is and silty ce }\end{array}$ & $\begin{array}{l}\text { coarse, } \\
\text { nent }\end{array}$ \\
\hline & & 30 & to & 33 & Clay, dark yellow, very & ilty, sandy & \\
\hline & & 33 & to & 35 & Gravel, varicolored; san & d, coarse, sub & unded \\
\hline \multirow{3}{*}{\multicolumn{2}{|c|}{ Pleistocene deposits }} & 35 & to & 43 & Till, medium light yello & $v$, oxidized, u & eached \\
\hline & & 43 & to & 56 & Till, orange-yellow, oxid & zed, unleach & \\
\hline & & 56 & to & 63 & Till, yellow-orange, oxid & zed, leached & \\
\hline \multirow{13}{*}{\multicolumn{2}{|c|}{$\begin{array}{l}\text { Pennsylvanian rocks, } \\
\text { undifferentiated }\end{array}$}} & 63 & to & 64 & Dolostone, very light gre & $y$, silt-grade, & alcareous \\
\hline & & 64 & to & 67 & $\begin{array}{l}\text { Dolostone, very light gra } \\
\text { limestone }\end{array}$ & y, silt-grade, & alcareous; \\
\hline & & 67 & to & 68 & Dolostone, yellow-orang & , silt-grade, & lcareous \\
\hline & & 68 & to & 69 & $\begin{array}{l}\text { Dolostone, yellow-orang } \\
\text { chert, brown }\end{array}$ & , silt-grade, & lcareous; \\
\hline & & 69 & to & 70 & Limestone, orange, silt- & rade & \\
\hline & & 70 & to & 71 & Limestone, very light or & ange-gray, sil & grade \\
\hline & & 71 & to & 72 & $\begin{array}{l}\text { Limestone, very light or } \\
\text { fragmented }\end{array}$ & ange-gray, sil & grade, \\
\hline & & 72 & to & 73 & Limestone, light brown, & silt-grade & \\
\hline & & 73 & to & 74 & Limestone, very light ye & llow, silt-grad & \\
\hline & & 74 & to & 76 & Limestone, light brown, & silt-grade & \\
\hline & & 76 & to & 77 & Limestone, light brown, & silt-grade, de & \\
\hline & & 77 & to & 79 & Limestone, very light gr & ay, light oran & e, silt-grade \\
\hline & & 79 & to & 81 & $\begin{array}{l}\text { Limestone, very light gr } \\
\text { medium }\end{array}$ & ay, orange, si & -grade to \\
\hline
\end{tabular}


Table 1. Geologic logs of test holes and observation wells drilled in southwest Iowa, 1985-87--Continued

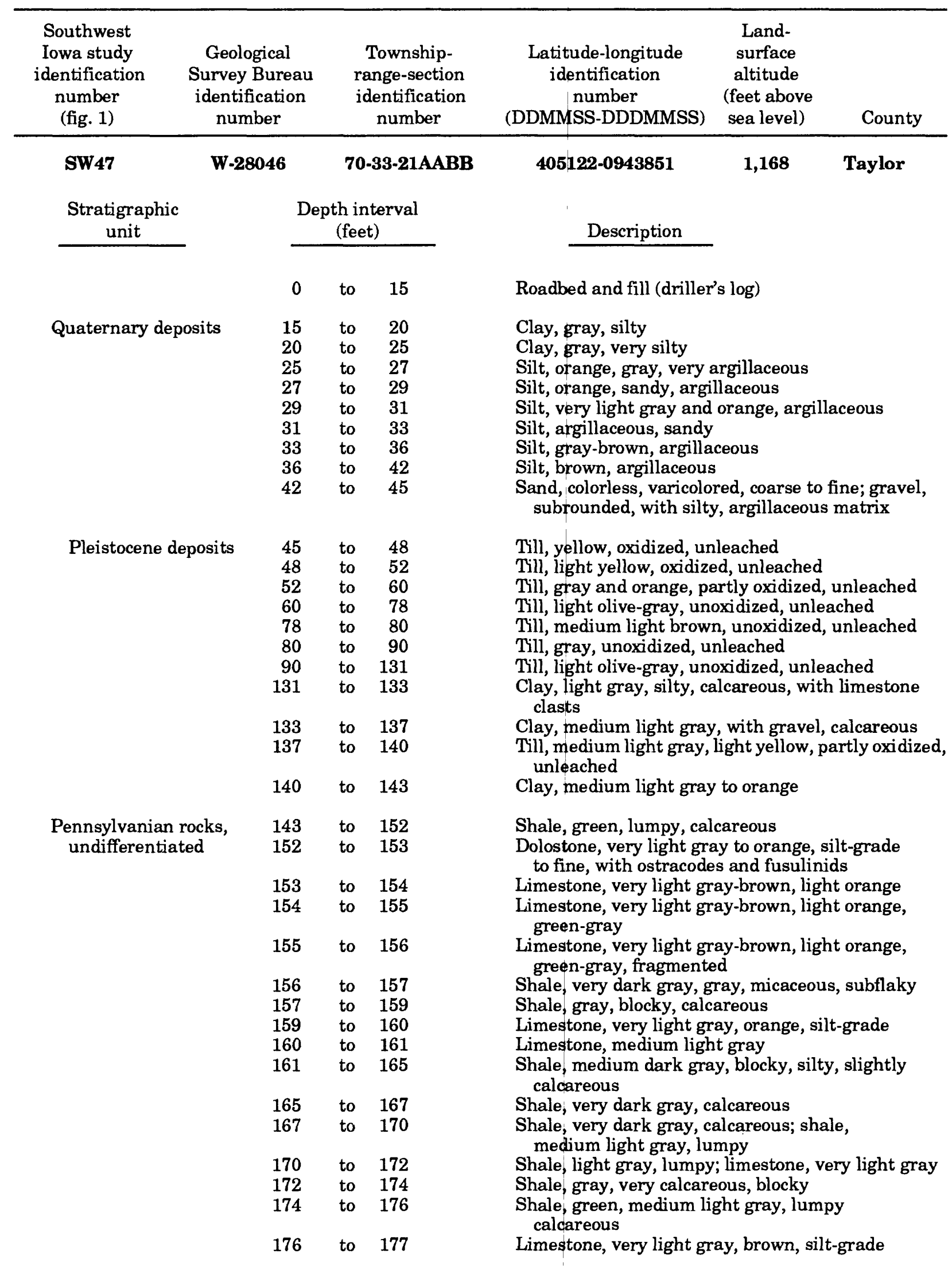


Table 1. Geologic logs of test holes and observation wells drilled in southwest Iowa, 1985-87--Continued

\begin{tabular}{|c|c|c|c|c|c|c|c|}
\hline \multirow{2}{*}{$\begin{array}{c}\begin{array}{c}\text { Southwest } \\
\text { Iowa study } \\
\text { identification } \\
\text { number } \\
\text { (fig. 1) }\end{array} \\
\text { SW48 }\end{array}$} & \multicolumn{2}{|c|}{$\begin{array}{c}\text { Geological } \\
\text { Survey Bureau } \\
\text { identification } \\
\text { number }\end{array}$} & \multicolumn{2}{|c|}{$\begin{array}{l}\text { Township- } \\
\text { range-section } \\
\text { identification } \\
\text { number }\end{array}$} & \multirow{2}{*}{$\begin{array}{c}\begin{array}{c}\text { Latitude-longitude } \\
\text { identification } \\
\text { number }\end{array} \\
\text { (DDMMSS-DDDMMSS) } \\
\mathbf{4 0 4 2 4 5 - 0 9 4 3 9 4 5}\end{array}$} & $\begin{array}{l}\text { Land- } \\
\text { surface } \\
\text { altitude } \\
\text { (feet above } \\
\text { sea level) }\end{array}$ & \multirow{2}{*}{$\frac{\text { County }}{\text { Taylor }}$} \\
\hline & W-2 & & & 33-08AAAB & & 1,122 & \\
\hline \multirow{2}{*}{\multicolumn{2}{|c|}{$\begin{array}{c}\text { Stratigraphic } \\
\text { unit } \\
\end{array}$}} & \multicolumn{3}{|c|}{$\begin{array}{c}\text { Depth interval } \\
\text { (feet) }\end{array}$} & Description & & \\
\hline & & 0 & to & 5 & Roadbed (driller's log) & & \\
\hline \multicolumn{2}{|c|}{ Quaternary deposits } & $\begin{array}{r}5 \\
16 \\
20 \\
29 \\
38\end{array}$ & $\begin{array}{l}\text { to } \\
\text { to } \\
\text { to } \\
\text { to } \\
\text { to }\end{array}$ & $\begin{array}{l}16 \\
20 \\
29 \\
38 \\
41\end{array}$ & \multicolumn{3}{|c|}{$\begin{array}{l}\text { Clay, light brown-gray, slightly silty } \\
\text { Clay, light gray, mottled orange, silty } \\
\text { Clay, light gray, mottled orange, very silty } \\
\text { Silt, orange-brown, argillaceous } \\
\text { Gravel, varicolored, subrounded; sand, coarse }\end{array}$} \\
\hline \multirow{3}{*}{\multicolumn{2}{|c|}{ Pleistocene deposits }} & $\begin{array}{l}41 \\
60 \\
70\end{array}$ & $\begin{array}{l}\text { to } \\
\text { to } \\
\text { to }\end{array}$ & $\begin{array}{l}60 \\
70 \\
80\end{array}$ & \multirow{3}{*}{\multicolumn{3}{|c|}{$\begin{array}{l}\text { Till, light olive-gray, unoxidized, unleached } \\
\text { Till, medium light gray, unoxidized, unleached } \\
\text { Till, medium light gray, unoxidized, unleached; } \\
\text { sand, colorless, varicolored, coarse to } \\
\text { medium; gravel, subrounded } \\
\text { Till, medium light gray, unoxidized, unleached } \\
\text { Till, medium light gray, unoxidized, unleached, } \\
\text { gravelly } \\
\text { Till, medium light gray, unoxidized, unleached } \\
\text { Till, medium light gray, unoxidized, unleached; } \\
\text { gravel, varicolored }\end{array}$}} \\
\hline & & $\begin{array}{l}80 \\
89\end{array}$ & $\begin{array}{l}\text { to } \\
\text { to }\end{array}$ & $\begin{array}{l}89 \\
92\end{array}$ & & & \\
\hline & & $\begin{array}{l}92 \\
97\end{array}$ & $\begin{array}{l}\text { to } \\
\text { to }\end{array}$ & $\begin{array}{l}97 \\
98\end{array}$ & & & \\
\hline \multirow{13}{*}{\multicolumn{2}{|c|}{$\begin{array}{l}\text { Pennsylvanian rocks, } \\
\text { undifferentiated }\end{array}$}} & 98 & to & 102 & \multirow{13}{*}{\multicolumn{3}{|c|}{$\begin{array}{l}\text { Limestone, very light gray, silt-grade; shale, very } \\
\text { pale green, calcareous } \\
\text { Limestone, very light gray, silt-grade } \\
\text { Limestone, very light gray with dark gray mottling } \\
\text { Shale, brown, blocky; shale, very dark gray } \\
\text { Shale, dark gray } \\
\text { Shale, gray, calcareous } \\
\text { Limestone, gray, silt-grade, calcareous } \\
\text { Shale, gray } \\
\text { Dolostone, gray, argillaceous, silt-grade; shale } \\
\text { Dolostone, very light gray, silt-grade } \\
\text { Dolostone, light gray, silt-grade, calcareous } \\
\text { Dolostone, very light gray, silt-grade } \\
\text { Dolostone, very light gray, light gray, silt-grade }\end{array}$}} \\
\hline & & 102 & to & 103 & & & \\
\hline & & 103 & to & 104 & & & \\
\hline & & 104 & to & 107 & & & \\
\hline & & 107 & to & 109 & & & \\
\hline & & 109 & to & 110 & & & \\
\hline & & 110 & to & 111 & & & \\
\hline & & 111 & to & 112 & & & \\
\hline & & 112 & & 114 & & & \\
\hline & & 114 & to & 115 & & & \\
\hline & & 115 & to & 117 & & & \\
\hline & & 117 & to & 120 & & & \\
\hline & & 120 & to & 121 & & & \\
\hline
\end{tabular}


Table 1. Geologic logs of test holes and observation wells drilled in southwest Iowa, 1985-87--Continued

\begin{tabular}{|c|c|c|c|c|c|c|c|}
\hline \multirow{2}{*}{$\begin{array}{c}\begin{array}{c}\text { Southwest } \\
\text { Iowa study } \\
\text { identification } \\
\text { number } \\
\text { (fig. 1) }\end{array} \\
\text { SW49 }\end{array}$} & \multicolumn{2}{|c|}{$\begin{array}{l}\text { Geological } \\
\text { Survey Bureau } \\
\text { identification } \\
\text { number }\end{array}$} & \multicolumn{2}{|c|}{$\begin{array}{l}\text { Township- } \\
\text { range-section } \\
\text { identification } \\
\text { number }\end{array}$} & \multirow{2}{*}{$\begin{array}{c}\begin{array}{c}\text { Latitude-longitude } \\
\text { identification } \\
\text { number }\end{array} \\
\text { (DDMMSS-DDDMMSS) }\end{array}$} & $\begin{array}{l}\text { Land- } \\
\text { surface } \\
\text { altitude } \\
\text { (feet above } \\
\text { sea level) }\end{array}$ & \multirow{2}{*}{ County } \\
\hline & W-2 & & & 6-31BCCA & & 960 & \\
\hline \multicolumn{2}{|c|}{$\begin{array}{l}\text { Stratigraphic } \\
\text { unit }\end{array}$} & \multicolumn{3}{|c|}{$\begin{array}{l}\text { Depth interval } \\
\text { (feet) }\end{array}$} & Description & & \\
\hline \multicolumn{2}{|c|}{ Quaternary deposits } & $\begin{array}{r}0 \\
5 \\
12 \\
14 \\
20\end{array}$ & $\begin{array}{l}\text { to } \\
\text { to } \\
\text { to } \\
\text { to } \\
\text { to }\end{array}$ & $\begin{array}{r}5 \\
12 \\
14 \\
20 \\
27\end{array}$ & \multicolumn{3}{|c|}{$\begin{array}{l}\text { Roadbed and topsoil (driller's log) } \\
\text { Clay, brown, silty } \\
\text { Clay, gray and dark brown, silty } \\
\text { Clay, medium light gray, silty } \\
\text { Gravel; sand, medium, subrounded to } \\
\text { subangular; trace silty, argillaceous matrix }\end{array}$} \\
\hline \multicolumn{2}{|c|}{$\begin{array}{l}\text { Pennsylvanian rocks, } \\
\text { undifferentiated }\end{array}$} & $\begin{array}{l}27 \\
28 \\
30 \\
31 \\
33 \\
34 \\
36\end{array}$ & $\begin{array}{l}\text { to } \\
\text { to } \\
\text { to } \\
\text { to } \\
\text { to } \\
\text { to } \\
\text { to }\end{array}$ & $\begin{array}{l}28 \\
30 \\
31 \\
33 \\
34 \\
36 \\
\\
38\end{array}$ & \multicolumn{3}{|c|}{$\begin{array}{l}\text { Shale, gray, yellow, lumpy, calcareous } \\
\text { Shale, gray, lumpy, calcareous } \\
\text { Shale, light gray, flaky, silty, calcareous } \\
\text { Limestone, light gray, argillaceous } \\
\text { Limestone, light gray, argillaceous; shale } \\
\text { Dolostone, very light gray, silt-grade to coarse, } \\
\text { crystalline, very calcareous } \\
\text { Dolostone, very light gray, silt-grade to coarse, } \\
\text { crystalline, very calcareous; limestone, dark } \\
\text { gray, mottled, argillaceous }\end{array}$} \\
\hline $\begin{array}{l}\text { Southwest } \\
\text { Iowa study } \\
\text { identification } \\
\text { number } \\
\text { (fig. 1) }\end{array}$ & \multicolumn{2}{|c|}{$\begin{array}{l}\text { Geological } \\
\text { Survey Bureau } \\
\text { identification } \\
\text { number }\end{array}$} & \multicolumn{2}{|c|}{$\begin{array}{l}\text { Township- } \\
\text { range-section } \\
\text { identification } \\
\text { number }\end{array}$} & $\begin{array}{c}\text { Latitude-longitude } \\
\text { identification } \\
\text { number } \\
\text { (DDMMSS-DDDMMSS) }\end{array}$ & $\begin{array}{l}\text { Land- } \\
\text { surface } \\
\text { altitude } \\
\text { (feet above } \\
\text { sea level) }\end{array}$ & County \\
\hline SW50 & \multicolumn{2}{|c|}{ W-28049 } & \multicolumn{2}{|c|}{ 69-36-16CBCB } & 404634-0950010 & 992 & Taylor \\
\hline $\begin{array}{c}\text { Stratigra } \\
\text { unit }\end{array}$ & & & & val & Description & & \\
\hline \multicolumn{2}{|c|}{ Quaternary deposits } & $\begin{array}{r}0 \\
5 \\
10 \\
15 \\
21 \\
25\end{array}$ & $\begin{array}{l}\text { to } \\
\text { to } \\
\text { to } \\
\text { to } \\
\text { to } \\
\text { to }\end{array}$ & $\begin{array}{r}5 \\
10 \\
15 \\
21 \\
25 \\
27\end{array}$ & \multicolumn{3}{|c|}{$\begin{array}{l}\text { Roadbed and topsoil (driller's log) } \\
\text { Clay, gray, slightly silty } \\
\text { Clay, medium light gray, slightly silty } \\
\text { Clay, light gray with orange mottling, slightly silty } \\
\text { Clay, gray, medium light gray, slightly silty } \\
\text { Clay, gray and orange mottled, silty, with plant } \\
\text { fossils }\end{array}$} \\
\hline \multicolumn{2}{|c|}{ Pleistocene deposits } & 27 & to & 30 & \multicolumn{3}{|c|}{ Till, gray, unoxidized, unleached } \\
\hline \multicolumn{2}{|c|}{$\begin{array}{l}\text { Pennsylvanian rocks, } \\
\text { undifferentiated }\end{array}$} & $\begin{array}{l}30 \\
32 \\
35\end{array}$ & $\begin{array}{l}\text { to } \\
\text { to }\end{array}$ & $\begin{array}{l}32 \\
35 \\
36\end{array}$ & \multicolumn{3}{|c|}{$\begin{array}{l}\text { Shale, gray, lumpy, soft, calcareous, micaceous } \\
\text { Shale, green-gray, lumpy, soft, calcareous, } \\
\text { micaceous } \\
\text { Shale, blue-gray, silty, calcareous, lumpy }\end{array}$} \\
\hline
\end{tabular}


Table 1. Geologic logs of test holes and observation wells drilled in southwest Iowa, 1985-87--Continued

\begin{tabular}{|c|c|c|c|c|c|c|c|}
\hline \multicolumn{2}{|c|}{$\begin{array}{c}\text { Stratigraphic } \\
\text { unit }\end{array}$} & \multicolumn{3}{|c|}{$\begin{array}{c}\text { Depth interval } \\
\text { (feet) }\end{array}$} & Description & & \\
\hline \multicolumn{8}{|c|}{ SW50--Continued } \\
\hline \multirow{3}{*}{\multicolumn{2}{|c|}{$\begin{array}{l}\text { Pennsylvanian rocks, } \\
\text { undifferentiated-- } \\
\text { Continued }\end{array}$}} & $\begin{array}{l}36 \\
37\end{array}$ & $\begin{array}{l}\text { to } \\
\text { to }\end{array}$ & $\begin{array}{l}37 \\
38\end{array}$ & \multirow{3}{*}{\multicolumn{3}{|c|}{$\begin{array}{l}\text { Shale, blue-gray, silty, very calcareous, lumpy; } \\
\text { limestone } \\
\text { Dolostone, medium light gray, very argillaceous; } \\
\text { shale } \\
\text { Shale, brown and medium dark gray, silty, } \\
\text { calcareous, subflaky } \\
\text { Shale, medium light gray, lumpy, silty, calcareous; } \\
\text { shale, dark gray, subflaky, silty, calcareous }\end{array}$}} \\
\hline & & 38 & to & 40 & & & \\
\hline & & 40 & to & 41 & & & \\
\hline $\begin{array}{l}\text { Southwest } \\
\text { Iowa study } \\
\text { identification } \\
\text { number } \\
\text { (fig. 1) }\end{array}$ & \multicolumn{2}{|c|}{$\begin{array}{l}\text { Geological } \\
\text { Survey Bureau } \\
\text { identification } \\
\text { number }\end{array}$} & \multicolumn{2}{|c|}{$\begin{array}{l}\text { Township- } \\
\text { range-section } \\
\text { identification } \\
\text { number }\end{array}$} & $\begin{array}{c}\text { Latitude-longitude } \\
\text { identification } \\
\text { number } \\
\text { (DDMMSS-DDDMMSS) }\end{array}$ & $\begin{array}{c}\text { Land- } \\
\text { surface } \\
\text { altitude } \\
\text { (feet above } \\
\text { sea level) }\end{array}$ & County \\
\hline SW51 & \multicolumn{2}{|c|}{ W-28050 } & \multicolumn{2}{|c|}{ 69-36-13ACCB } & 404648-0945614 & 1,015 & Page \\
\hline \multirow{2}{*}{\multicolumn{2}{|c|}{$\begin{array}{l}\text { Stratigraphic } \\
\text { unit }\end{array}$}} & \multicolumn{3}{|c|}{$\begin{array}{l}\text { Depth interval } \\
\quad(\text { feet })\end{array}$} & Description & & \\
\hline & & 0 & to & 4 & Roadbed (driller's log) & & \\
\hline \multirow{7}{*}{\multicolumn{2}{|c|}{ Quaternary deposits }} & 4 & to & 13 & Clay, gray, silty & & \\
\hline & & 13 & to & 15 & Clay, very light brown, & ilty & \\
\hline & & 15 & to & 17 & Clay, very light gray, si & & \\
\hline & & 17 & to & 20 & Clay, pale orange, pale & rown, silty & \\
\hline & & 20 & to & 27 & Clay, very light gray, si & & \\
\hline & & 27 & to & 30 & Clay, medium light bro & in-gray, silty & \\
\hline & & 30 & to & 32 & $\begin{array}{l}\text { Gravel, varicolored; san } \\
\text { argillaceous matrix }\end{array}$ & d, coarse, with & \\
\hline \multirow{6}{*}{\multicolumn{2}{|c|}{$\begin{array}{l}\text { Pennsylvanian rocks, } \\
\text { undifferentiated }\end{array}$}} & 32 & to & 35 & Shale & & \\
\hline & & 35 & to & 36 & Shale, gray-brown, very & calcareous & \\
\hline & & 36 & to & 38.5 & Shale, gray, flaky, silty & & \\
\hline & & 38.5 & to & 39 & Shale, very dark gray, b & locky, carbona & eous \\
\hline & & 39 & to & 40 & $\begin{array}{l}\text { Shale, very light gray, } \\
\text { calcareous; dolostone, } \\
\text { argillaceous }\end{array}$ & $\begin{array}{l}\text { locky, carbona } \\
\text { light brown, s }\end{array}$ & eous, \\
\hline & & 40 & to & 41 & $\begin{array}{l}\text { Shale, very light gray, b } \\
\text { calcareous; limestone }\end{array}$ & $\begin{array}{l}\text { locky, carbona } \\
\text { gray, silt-gra }\end{array}$ & eous, \\
\hline
\end{tabular}


Table 1. Geologic logs of test holes and observation wells drilled in southwest Iowa, 1985-87--Continued

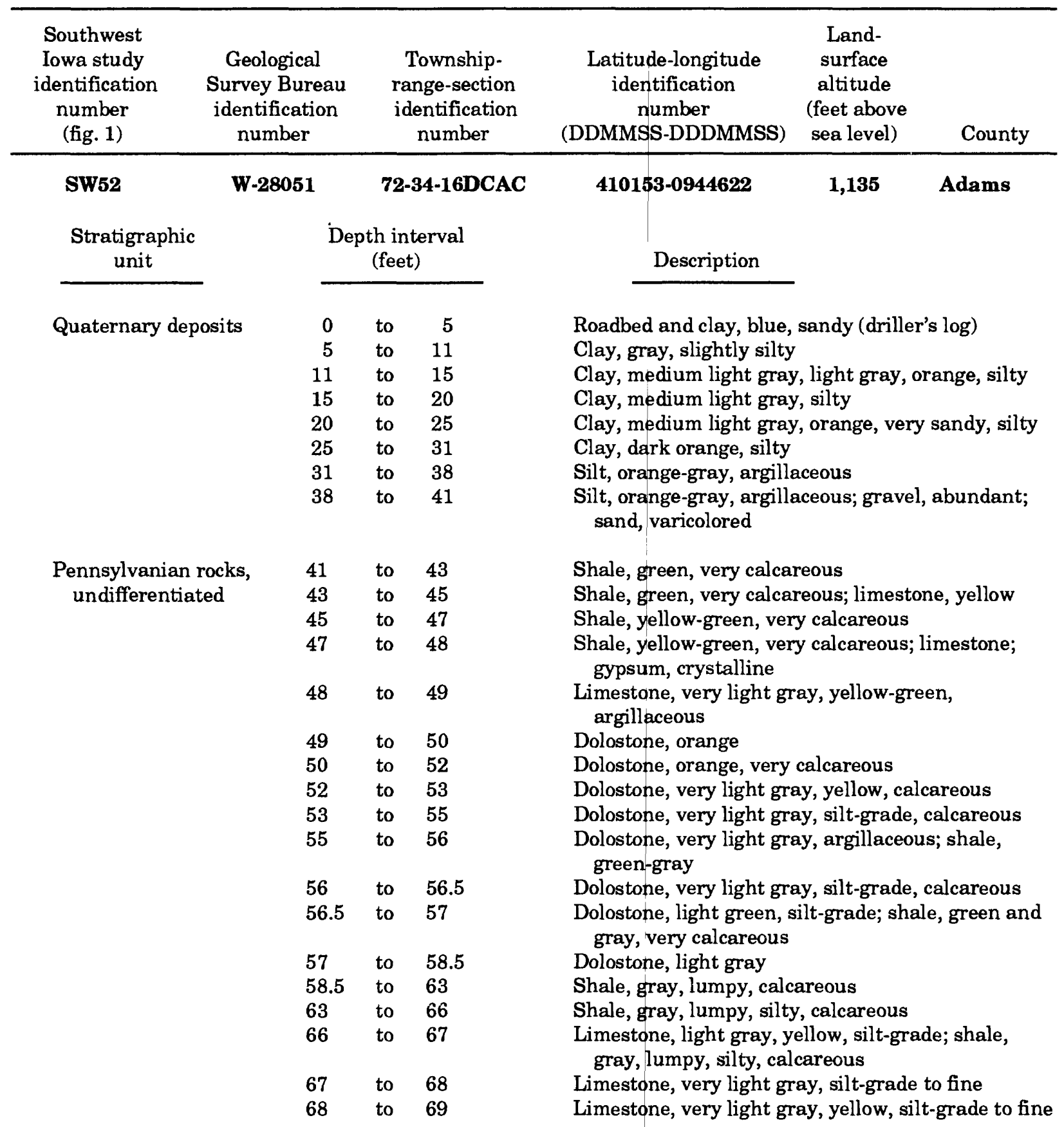


Table 1. Geologic logs of test holes and observation wells drilled in southwest Iowa, 1985-87--Continued

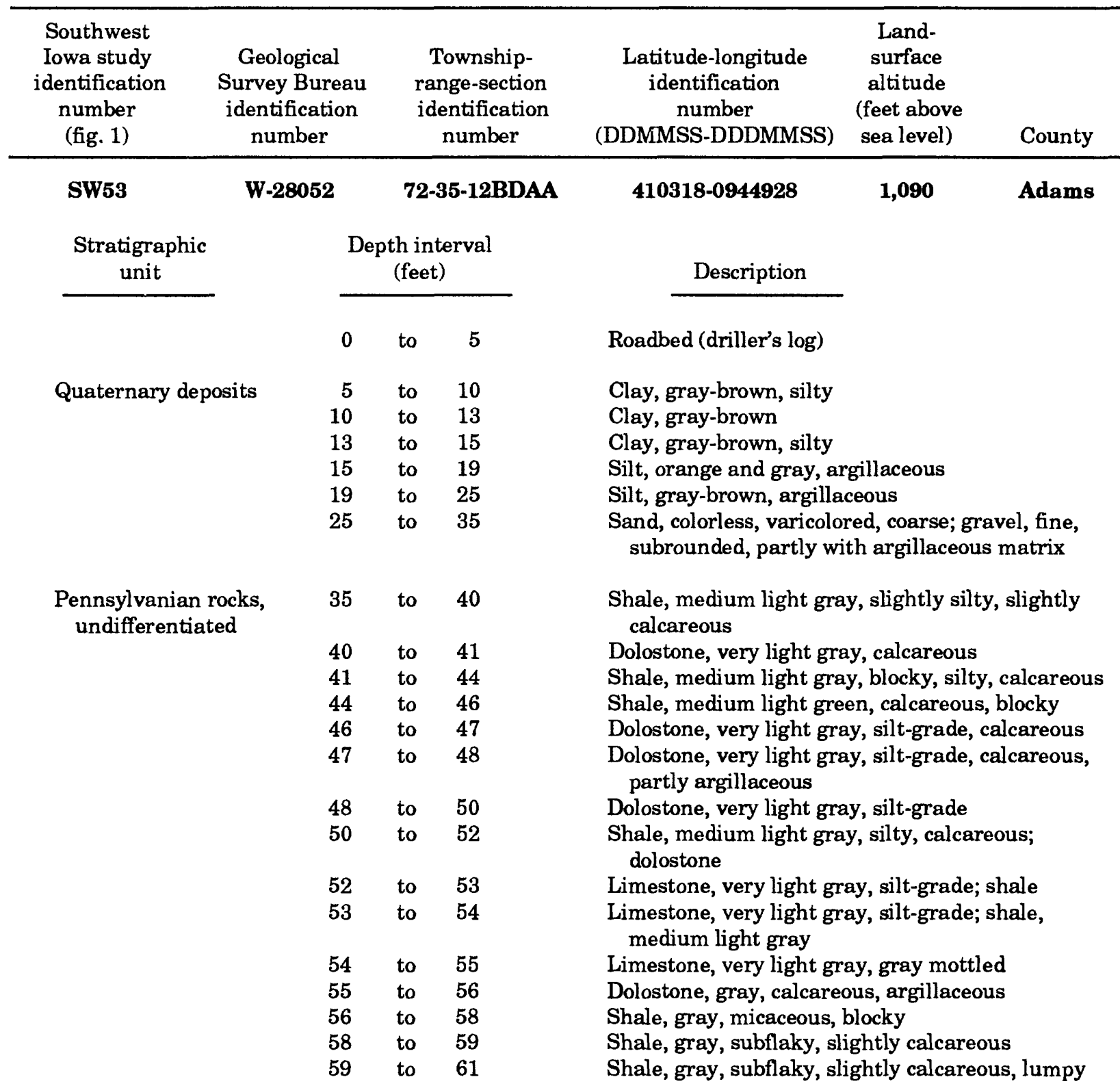


Table 1. Geologic logs of test holes and observation wells drilled in southwest Iowa, 1985-87--Continued

\begin{tabular}{|c|c|c|c|c|c|c|c|}
\hline \multirow{2}{*}{$\begin{array}{c}\begin{array}{c}\text { Southwest } \\
\text { Iowa study } \\
\text { identification } \\
\text { number } \\
\text { (fig. 1) }\end{array} \\
\text { SW54 }\end{array}$} & \multicolumn{2}{|c|}{$\begin{array}{l}\text { Geological } \\
\text { Survey Bureau } \\
\text { identification } \\
\text { number }\end{array}$} & \multicolumn{2}{|c|}{$\begin{array}{l}\text { Township- } \\
\text { range-section } \\
\text { identification } \\
\text { number }\end{array}$} & $\begin{array}{l}\text { Latitude-longitude } \\
\text { identification } \\
\text { number } \\
\text { (DDMMSS-DDDMMSS) }\end{array}$ & \multirow{2}{*}{$\begin{array}{c}\begin{array}{c}\text { Land- } \\
\text { surface } \\
\text { altitude } \\
\text { (feet above } \\
\text { sea level) }\end{array} \\
\mathbf{1 , 1 3 0}\end{array}$} & \multirow{2}{*}{$\begin{array}{l}\text { County } \\
\text { Cass }\end{array}$} \\
\hline & W-2 & & & 35-31CBBC & $410951-0945537$ & & \\
\hline \multicolumn{2}{|c|}{$\begin{array}{l}\text { Stratigraphic } \\
\text { unit }\end{array}$} & \multicolumn{3}{|c|}{$\begin{array}{l}\text { Depth interval } \\
\text { (feet) }\end{array}$} & Description & & \\
\hline & & 0 & to & 5 & Roadbed (driller's log) & & \\
\hline \multirow{8}{*}{\multicolumn{2}{|c|}{ Quaternary deposits }} & 5 & to & 8 & \multirow{3}{*}{\multicolumn{3}{|c|}{$\begin{array}{l}\text { Clay, brown, silty } \\
\text { Clay, medium dark gray, silty } \\
\text { Clay, gray with orange mottling, silty }\end{array}$}} \\
\hline & & 8 & to & 13 & & & \\
\hline & & 13 & to & 18 & & & \\
\hline & & 18 & to & 20 & \multicolumn{3}{|c|}{ Clay, darker gray with orange mottling, silty } \\
\hline & & 20 & to & 31 & \multicolumn{3}{|c|}{ Silt, light yellow-gray } \\
\hline & & 31 & to & 36 & \multicolumn{3}{|c|}{$\begin{array}{l}\text { Sand, colorless, varicolored, coarse to fine; gravel, } \\
\text { subrounded }\end{array}$} \\
\hline & & 36 & to & 40 & \multicolumn{3}{|c|}{$\begin{array}{l}\text { Sand, colorless, varicolored, coarse to fine, trace } \\
\text { medium to fine; gravel, subrounded }\end{array}$} \\
\hline & & 40 & to & 43.5 & \multicolumn{3}{|c|}{$\begin{array}{l}\text { Sand, colorless, varicolored, coarse to fine; gravel, } \\
\text { subrounded; partly with argillaceous matrix }\end{array}$} \\
\hline \multirow{12}{*}{\multicolumn{2}{|c|}{$\begin{array}{l}\text { Pennsylvanian rocks, } \\
\text { undifferentiated }\end{array}$}} & 43.5 & to & 44 & \multirow{3}{*}{\multicolumn{3}{|c|}{$\begin{array}{l}\text { Shale, gray, blocky, hard } \\
\text { Shale, gray, lumpy, calcareous; trace dolostone } \\
\text { Shale, gray, lumpy, calcareous, with calcareous } \\
\text { fossils }\end{array}$}} \\
\hline & & 44 & to & 45 & & & \\
\hline & & 45 & to & 46 & & & \\
\hline & & 46 & to & 47 & \multicolumn{3}{|c|}{ Shale, gray, lumpy, calcareous, with fusulinids } \\
\hline & & 47 & to & 48 & \multicolumn{3}{|c|}{ Shale, light green-gray and gray, calcareous } \\
\hline & & 48 & to & 50 & \multicolumn{3}{|c|}{ Dolostone, very light gray, silt-grade, calcareous } \\
\hline & & 50 & to & 51 & \multicolumn{3}{|c|}{ Shale, very dark gray, flaky } \\
\hline & & 51 & to & 53 & \multicolumn{3}{|c|}{ Shale, medium dark gray, calcareous, silty, lumpy } \\
\hline & & 53 & to & 54 & \multicolumn{3}{|c|}{$\begin{array}{l}\text { Dolostone, orange, calcareous; shale, green, } \\
\text { calcareous }\end{array}$} \\
\hline & & 54 & to & 55 & \multirow{2}{*}{\multicolumn{3}{|c|}{ Dolostone, very light gray, calcareous }} \\
\hline & & 55 & to & 58 & \multirow{2}{*}{\multicolumn{3}{|c|}{$\begin{array}{l}\text { Limestone, very light gray, yellow, silt-grade } \\
\text { Limestone, very light gray, light yellow, silt-grade }\end{array}$}} \\
\hline & & 58 & to & 60 & & & \\
\hline
\end{tabular}


Table 1. Geologic logs of test holes and observation wells drilled in southwest Iowa, 1985-87--Continued

\begin{tabular}{|c|c|c|c|c|c|c|c|}
\hline \multirow{2}{*}{$\begin{array}{c}\begin{array}{c}\text { Southwest } \\
\text { Iowa study } \\
\text { identification } \\
\text { number } \\
\text { (fig. 1) }\end{array} \\
\text { SW55 }\end{array}$} & \multicolumn{2}{|c|}{$\begin{array}{c}\text { Geological } \\
\text { Survey Bureau } \\
\text { identification } \\
\text { number } \\
\end{array}$} & \multicolumn{2}{|c|}{$\begin{array}{l}\text { Township- } \\
\text { range-section } \\
\text { identification } \\
\text { number } \\
\end{array}$} & \multirow{2}{*}{$\begin{array}{c}\begin{array}{c}\text { Latitude-longitude } \\
\text { identification } \\
\text { number }\end{array} \\
\text { (DDMMSS-DDDMMSS) }\end{array}$} & \multirow{2}{*}{$\begin{array}{c}\begin{array}{c}\text { Land- } \\
\text { surface } \\
\text { altitude } \\
\text { (feet above } \\
\text { sea level) }\end{array} \\
1,080\end{array}$} & \multirow{2}{*}{$\begin{array}{l}\text { County } \\
\text { Page }\end{array}$} \\
\hline & & & & 37-06AADD & & & \\
\hline SW55 casing & & $\begin{array}{r}0 \\
58\end{array}$ & & $\begin{array}{l}58 \\
62\end{array}$ & Slotted & & \\
\hline $\begin{array}{c}\text { Stratigraph } \\
\text { unit }\end{array}$ & \multicolumn{4}{|c|}{$\begin{array}{c}\text { Depth interval } \\
\text { (feet) }\end{array}$} & Description & & \\
\hline \multicolumn{2}{|c|}{ Quaternary deposits } & $\begin{array}{r}0 \\
3 \\
5 \\
14 \\
18 \\
26 \\
30 \\
36 \\
50 \\
58 \\
\end{array}$ & $\begin{array}{l}\text { to } \\
\text { to } \\
\text { to } \\
\text { to } \\
\text { to } \\
\text { to } \\
\text { to } \\
\text { to } \\
\text { to } \\
\text { to } \\
\text { to }\end{array}$ & $\begin{array}{r}3 \\
5 \\
14 \\
18 \\
26 \\
30 \\
36 \\
50 \\
58 \\
60 \\
62\end{array}$ & \multicolumn{3}{|c|}{$\begin{array}{l}\text { Topsoil (driller's log) } \\
\text { Clay, blue-gray (driller's log) } \\
\text { Clay, gray, silty, blocky } \\
\text { Clay, light gray, silty, blocky } \\
\text { Clay, light gray, slightly silty, blocky } \\
\text { Silt, very light gray, very argillaceous } \\
\text { Clay, very light gray, very silty } \\
\text { Clay, light gray, silty } \\
\text { Silt, medium light gray, argillaceous } \\
\text { Sand, colorless, varicolored, coarse; gravel, } \\
\text { medium, dirty } \\
\text { Sand, colorless, varicolored, coarse; gravel, } \\
\text { medium, dirty; with argillaceous and silty matrix }\end{array}$} \\
\hline $\begin{array}{l}\text { Pennsylvania } \\
\text { undifferenti }\end{array}$ & $\begin{array}{l}\text { rocks, } \\
\text { ated }\end{array}$ & 62 & to & 65 & \multicolumn{3}{|c|}{ Dolostone, medium light gray, very argillaceous } \\
\hline $\begin{array}{l}\text { Southwest } \\
\text { Iowa study } \\
\text { identification } \\
\text { number } \\
\text { (fig. 1) }\end{array}$ & \multicolumn{2}{|c|}{$\begin{array}{l}\text { Geological } \\
\text { Survey Bureau } \\
\text { identification } \\
\text { number }\end{array}$} & \multicolumn{2}{|c|}{$\begin{array}{l}\text { Township- } \\
\text { range-section } \\
\text { identification } \\
\text { number }\end{array}$} & $\begin{array}{c}\text { Latitude-longitude } \\
\text { identification } \\
\text { number } \\
\text { (DDMMSS-DDDMMSS) }\end{array}$ & $\begin{array}{c}\text { Land- } \\
\text { surface } \\
\text { altitude } \\
\text { (feet above } \\
\text { sea level) }\end{array}$ & County \\
\hline SW56 & \multicolumn{2}{|c|}{ W-28117 } & \multicolumn{2}{|c|}{ 69-38-11ABAB } & 404801-0951053 & 1,040 & Page \\
\hline SW56 casing & & $\begin{array}{r}0 \\
50\end{array}$ & $\begin{array}{l}\text { to } \\
\text { to }\end{array}$ & $\begin{array}{l}50 \\
54\end{array}$ & Slotted & & \\
\hline $\begin{array}{c}\text { Stratigraphi } \\
\text { unit }\end{array}$ & & \multicolumn{3}{|c|}{$\begin{array}{c}\text { Depth interval } \\
\text { (feet) }\end{array}$} & Description & & \\
\hline \multicolumn{2}{|c|}{ Quaternary deposits } & $\begin{array}{r}0 \\
5 \\
12 \\
19 \\
28 \\
31\end{array}$ & $\begin{array}{l}\text { to } \\
\text { to } \\
\text { to } \\
\text { to } \\
\text { to } \\
\text { to }\end{array}$ & $\begin{array}{r}5 \\
12 \\
19 \\
28 \\
31 \\
40\end{array}$ & \multicolumn{3}{|c|}{$\begin{array}{l}\text { Topsoil and fill (driller's log) } \\
\text { Clay, gray, silty } \\
\text { Clay, medium light gray, silty } \\
\text { Silt, light yellow, argillaceous } \\
\text { Clay, brown-gray, silty } \\
\text { Silt, light yellow, argillaceous }\end{array}$} \\
\hline
\end{tabular}


Table 1. Geologic logs of test holes and observation wells drilled in southwest Iowa, 1985-87--Continued

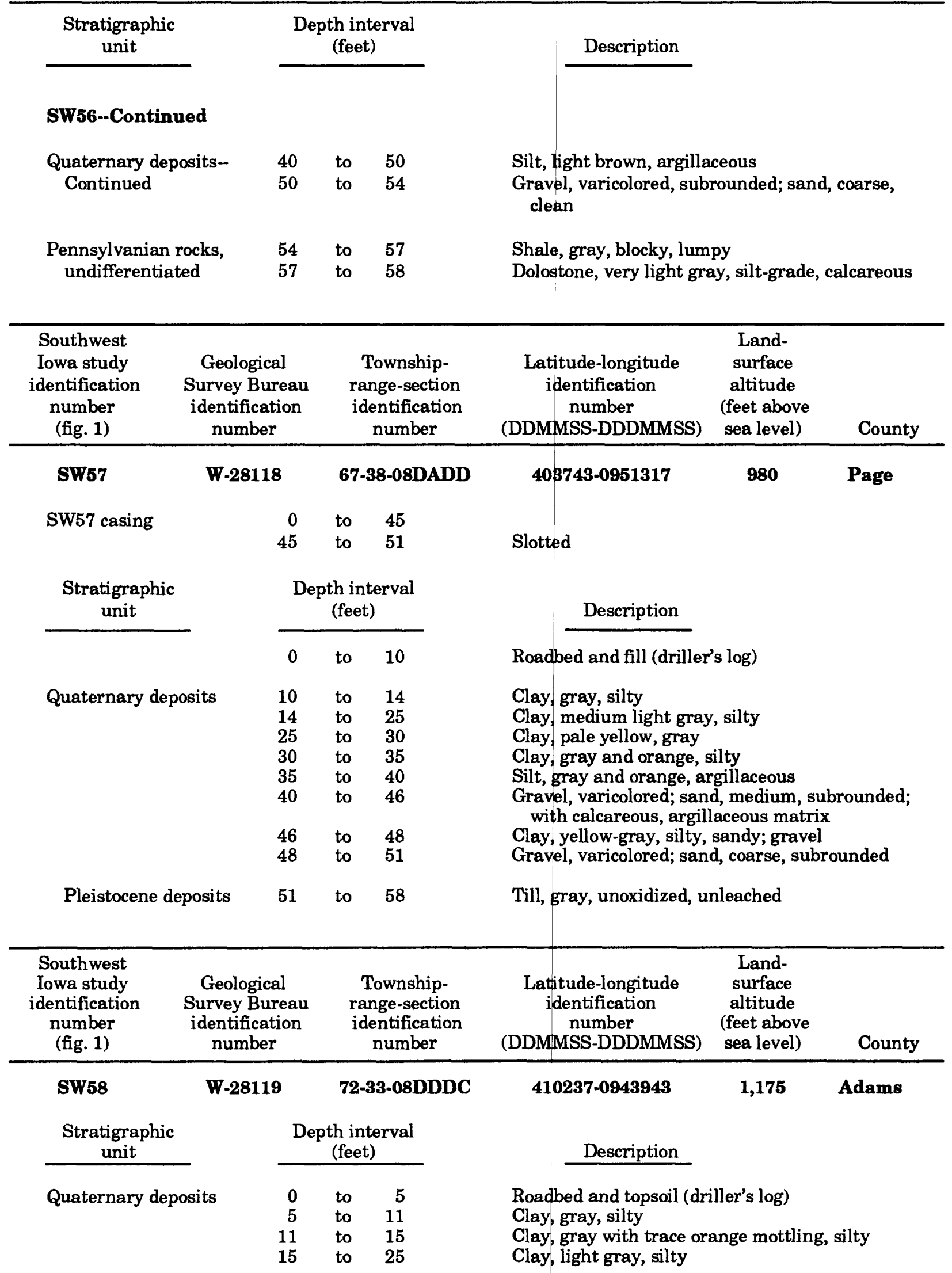


Table 1. Geologic logs of test holes and observation wells drilled in southwest lowa, 1985-87--Continued

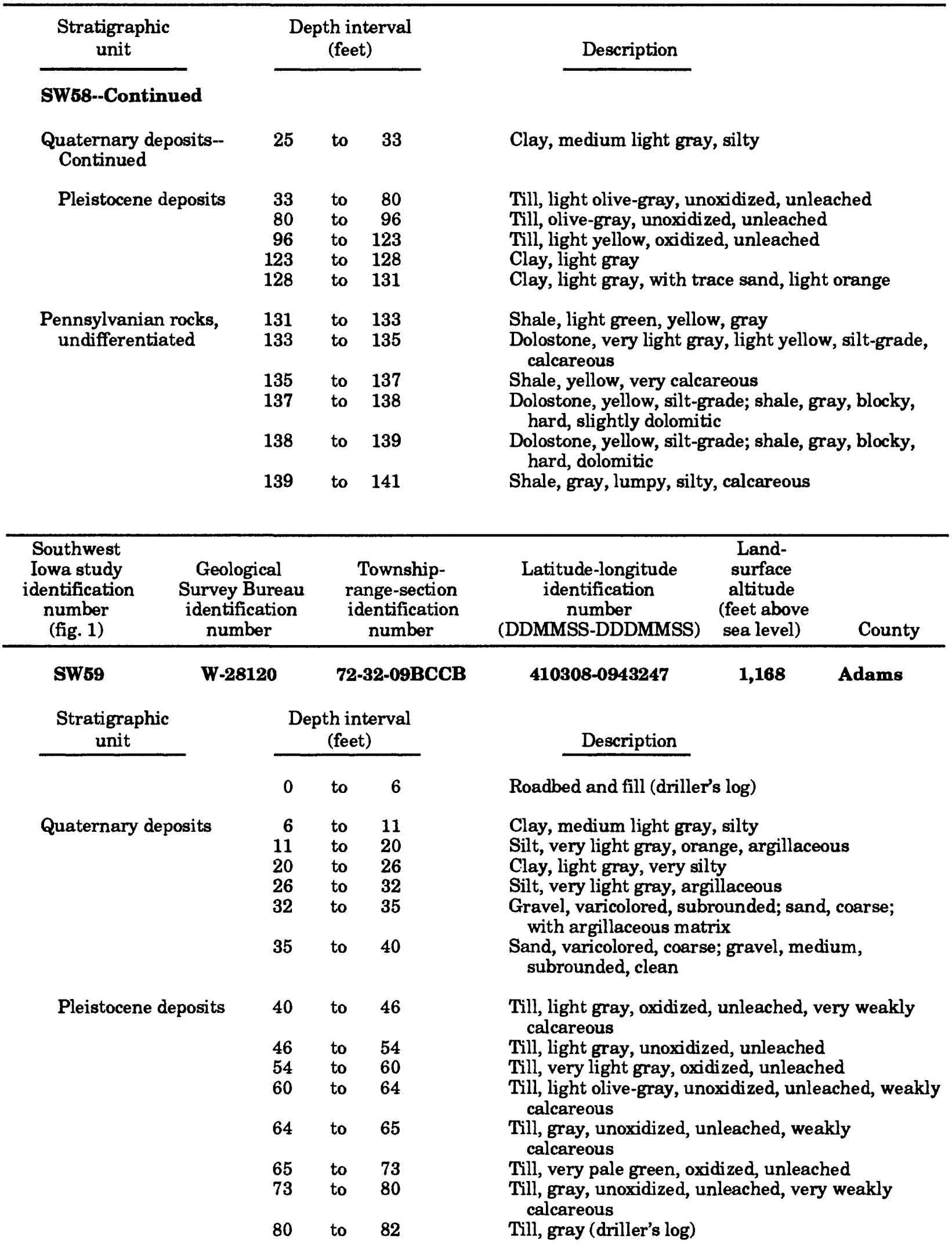


Table 1. Geologic logs of test holes and observation wells drilled in southwest Iowa, 1985-87--Continued

\begin{tabular}{l|c|c}
$\begin{array}{c}\text { Stratigraphic } \\
\text { unit }\end{array}$ & $\begin{array}{c}\text { Depth interval } \\
\text { (feet) }\end{array}$ & Description \\
\cline { 2 - 3 } SW59--Continued & 82 & Sand and gravel (driller's log)
\end{tabular}

Note: Well flows at the land surface from 300 to 400 gallons per minute from 82 feet below land surface.

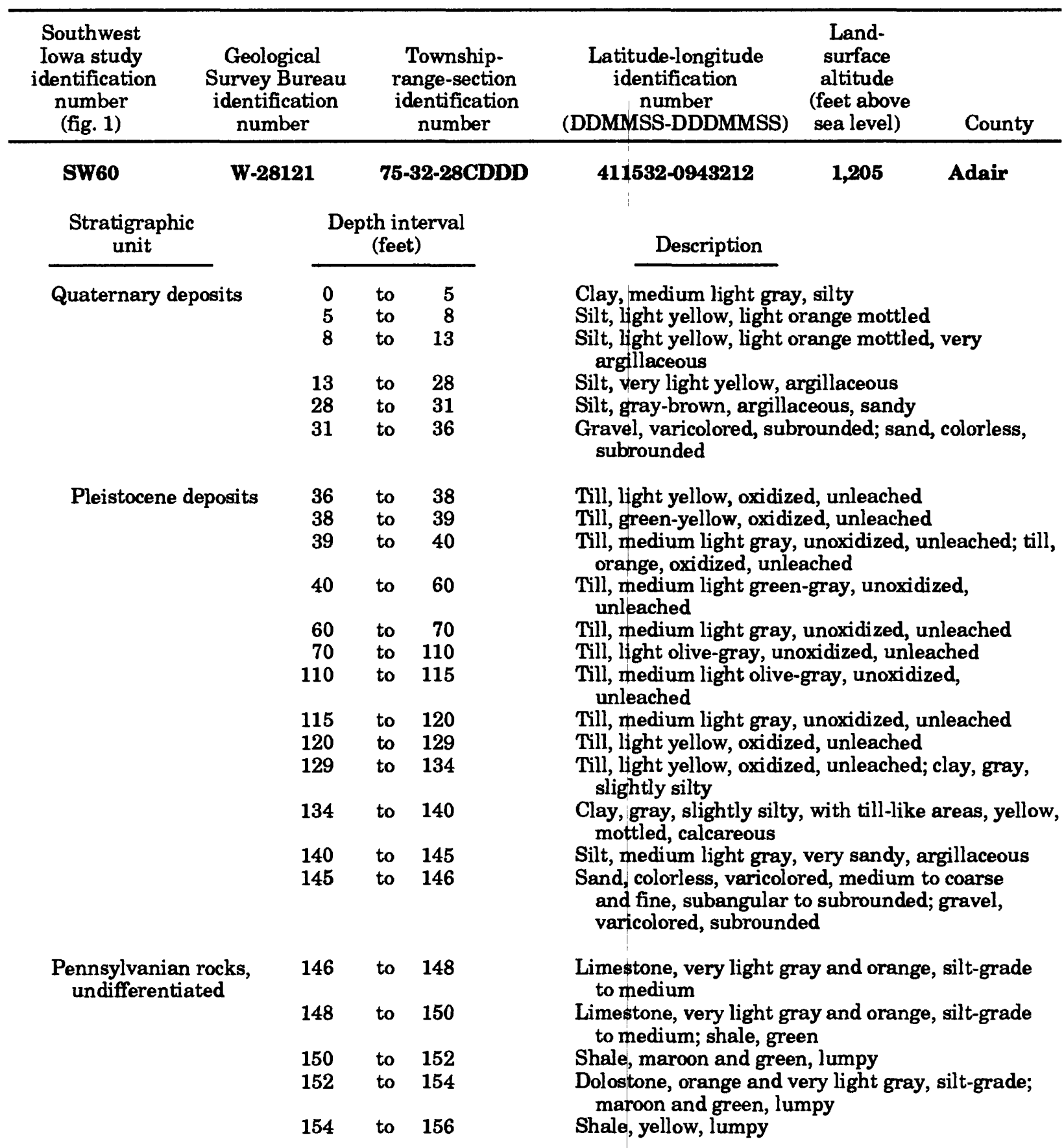


Table 1. Geologic logs of test holes and observation wells drilled in southwest Iowa, 1985-87--Continued

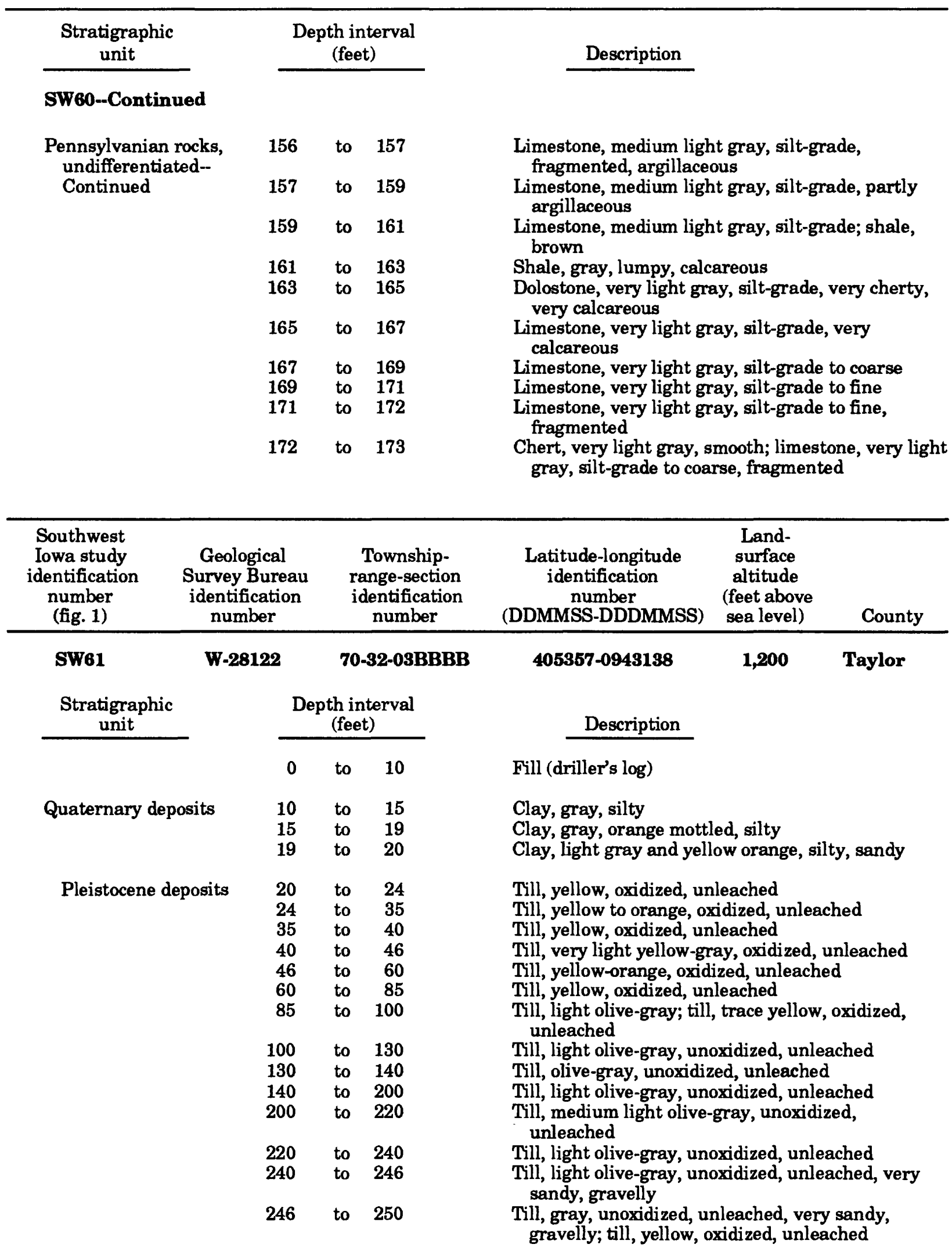


Table 1. Geologic logs of test holes and observation wells drilled in southwest Iowa, 1985-87-Continued

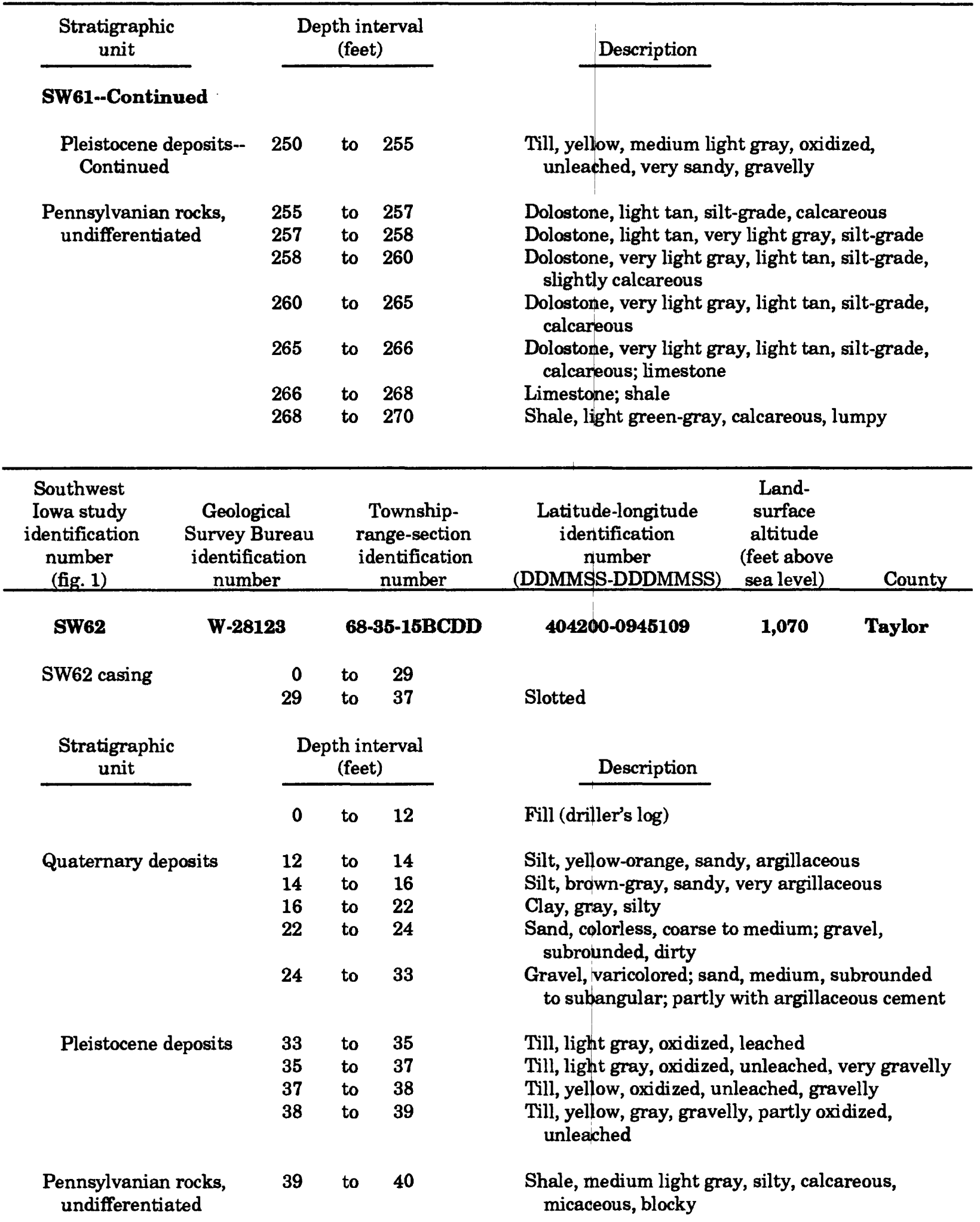


Table 1. Geologic logs of test holes and observation wells drilled in southwest Iowa, 1985-87--Continued

\begin{tabular}{|c|c|c|c|c|c|c|c|}
\hline \multirow{2}{*}{$\begin{array}{c}\begin{array}{c}\text { Southwest } \\
\text { Iowa study } \\
\text { identification } \\
\text { number } \\
\text { (fig. 1) }\end{array} \\
\text { SW63 }\end{array}$} & \multicolumn{2}{|c|}{$\begin{array}{c}\text { Geological } \\
\text { Survey Bureau } \\
\text { identification } \\
\text { number } \\
\end{array}$} & \multicolumn{2}{|c|}{$\begin{array}{l}\text { Township- } \\
\text { range-section } \\
\text { identification } \\
\text { number }\end{array}$} & \multirow{2}{*}{$\begin{array}{c}\begin{array}{c}\text { Latitude-longitude } \\
\text { identification } \\
\text { number }\end{array} \\
\text { (DDMMSS-DDDMMSS) }\end{array}$} & $\begin{array}{l}\text { Land- } \\
\text { surface } \\
\text { altitude } \\
\text { (feet above } \\
\text { sea level) }\end{array}$ & \multirow{2}{*}{$\frac{\text { County }}{\text { Page }}$} \\
\hline & $\mathbf{W} \cdot \mathbf{2}$ & & & 6-02AAAA & & 1,020 & \\
\hline \multicolumn{2}{|c|}{$\begin{array}{l}\text { Stratigraphic } \\
\text { unit }\end{array}$} & \multicolumn{3}{|c|}{$\begin{array}{l}\text { Depth interval } \\
\text { (feet) }\end{array}$} & Description & & \\
\hline & & 0 & to & 7 & Roadbed and fill (driller' & 's log) & \\
\hline \multirow{6}{*}{\multicolumn{2}{|c|}{ Quaternary deposits }} & 7 & to & 10 & \multirow{6}{*}{\multicolumn{3}{|c|}{$\begin{array}{l}\text { Clay, medium dark gray, silty } \\
\text { Clay, medium light gray } \\
\text { Silt, yellow, argillaceous } \\
\text { Silt, yellow, very argillaceous } \\
\text { Silt, gray and orange, very argillaceous } \\
\text { Silt, gray, argillaceous; sand, coarse; gravel }\end{array}$}} \\
\hline & & 10 & to & 16 & & & \\
\hline & & 16 & to & 20 & & & \\
\hline & & 20 & to & 26 & & & \\
\hline & & 26 & to & 27 & & & \\
\hline & & 27 & to & 35 & & & \\
\hline \multirow{23}{*}{\multicolumn{2}{|c|}{$\begin{array}{l}\text { Pennsylvanian rocks, } \\
\text { undifferentiated }\end{array}$}} & 35 & to & 38 & \multirow{5}{*}{\multicolumn{3}{|c|}{$\begin{array}{l}\text { Shale, medium light gray, flaky } \\
\text { Shale, medium light gray, flaky; shale, very dark } \\
\text { gray, carbonaceous } \\
\text { Shale, medium light gray, flaky } \\
\text { Shale, very dark gray, flaky, carbonaceous } \\
\text { Shale, light green-gray, micaceous, subflaky, } \\
\text { slightly calcareous }\end{array}$}} \\
\hline & & 38 & to & 40 & & & \\
\hline & & 40 & to & 42 & & & \\
\hline & & 42 & to & 43 & & & \\
\hline & & 43 & to & 45 & & & \\
\hline & & 45 & to & 50 & \multicolumn{3}{|c|}{$\begin{array}{l}\text { Shale, light green-gray, micaceous, subflaky, } \\
\text { calcareous }\end{array}$} \\
\hline & & 50 & to & 53 & \multirow{3}{*}{\multicolumn{3}{|c|}{$\begin{array}{l}\text { Shale, gray, soft, lumpy, subflaky, silty } \\
\text { Shale, gray, subflaky, micaceous, calcareous } \\
\text { Shale, gray, subflaky, micaceous, calcareous; } \\
\text { limestone, gray }\end{array}$}} \\
\hline & & 53 & to & 56 & & & \\
\hline & & 56 & to & 60 & & & \\
\hline & & 60 & to & 61 & \multicolumn{3}{|c|}{$\begin{array}{l}\text { Shale, light green-gray, subflaky, micaceous, } \\
\text { calcareous; limestone, gray }\end{array}$} \\
\hline & & 61 & to & 63 & \multicolumn{3}{|c|}{$\begin{array}{l}\text { Shale, light green-gray, subflaky, micaceous, } \\
\text { calcareous; dolostone }\end{array}$} \\
\hline & & 63 & to & 64 & \multicolumn{3}{|c|}{ Dolostone, gray, argillaceous } \\
\hline & & 64 & to & 66 & \multicolumn{3}{|c|}{ Shale, very dark gray, gray, blocky } \\
\hline & & 66 & to & 67 & \multicolumn{3}{|c|}{ Dolostone, gray, argillaceous, silt-grade to coarse } \\
\hline & & 67 & to & 69 & \multicolumn{3}{|c|}{ Dolostone, gray, calcareous, argillaceous } \\
\hline & & 69 & to & 70 & \multicolumn{3}{|c|}{ Dolostone, light green, silt-grade, argillaceous } \\
\hline & & 70 & to & 71 & \multicolumn{3}{|c|}{ Shale, gray, lumpy, dolomitic } \\
\hline & & 71 & to & 74 & \multicolumn{3}{|c|}{ Shale, gray, lumpy, dolomitic; dolostone } \\
\hline & & 74 & to & 75 & \multicolumn{3}{|c|}{ Limestone, light brown-gray, silt-grade to coarse } \\
\hline & & 75 & to & 77 & \multicolumn{3}{|c|}{ Shale, pale green, lumpy, calcareous } \\
\hline & & 77 & to & 78 & \multirow{2}{*}{\multicolumn{3}{|c|}{$\begin{array}{l}\text { Dolostone, very light gray, silt-grade, argillaceous } \\
\text { Dolostone, very light gray, silt-grade, calcareous, } \\
\text { argillaceous }\end{array}$}} \\
\hline & & 78 & to & 80 & & & \\
\hline & & 80 & to & 81 & \multicolumn{3}{|c|}{ Shale, medium light green-gray, very calcareous } \\
\hline
\end{tabular}


Table 1. Geologic logs of test holes and observation wells drilled in southwest Iowa, 1985-87--Continued

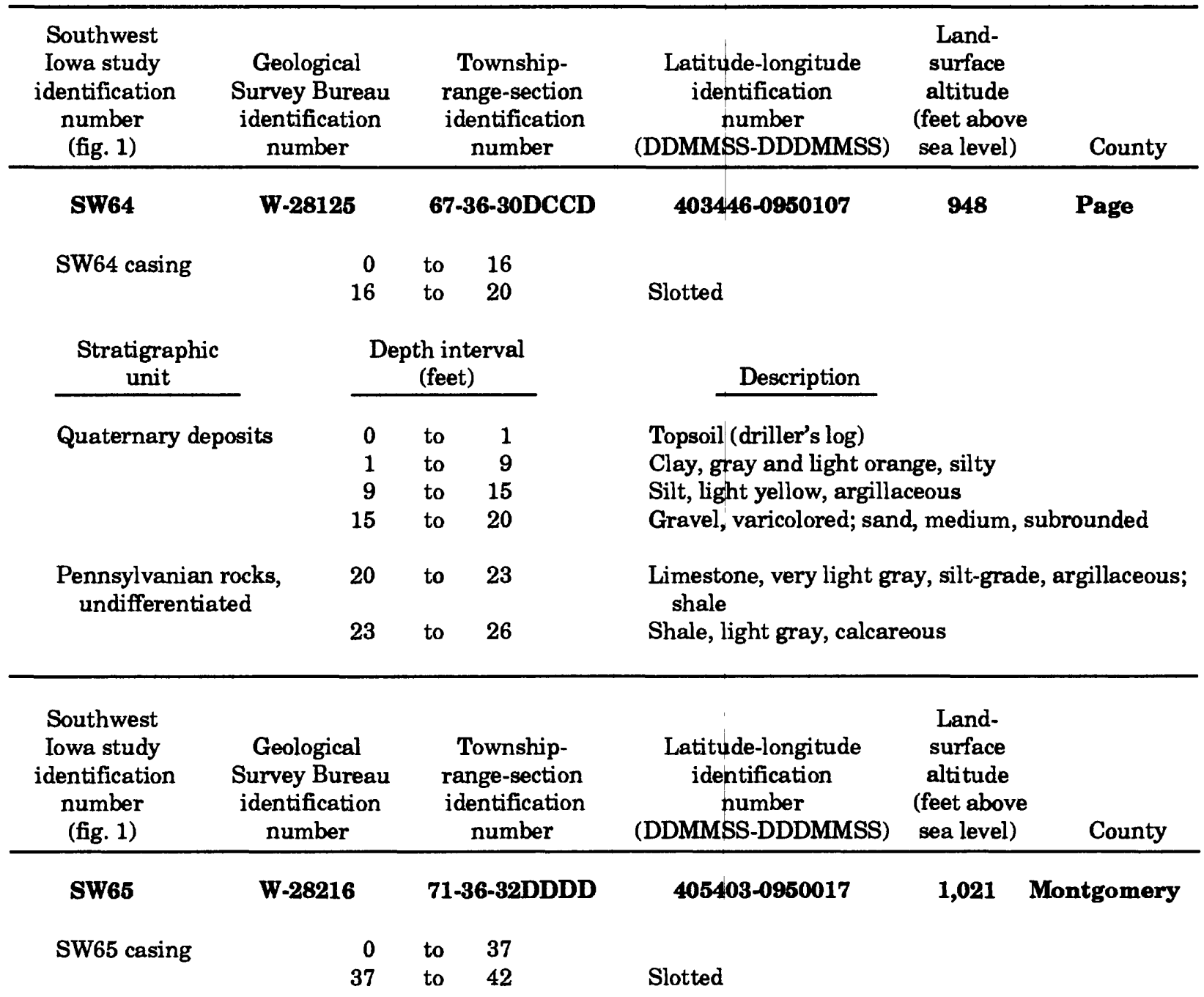

Same location as SW42, see log for SW42 for description. 
Table 1. Geologic logs of test holes and observation wells drilled in southwest Iowa, 1985-87--Continued

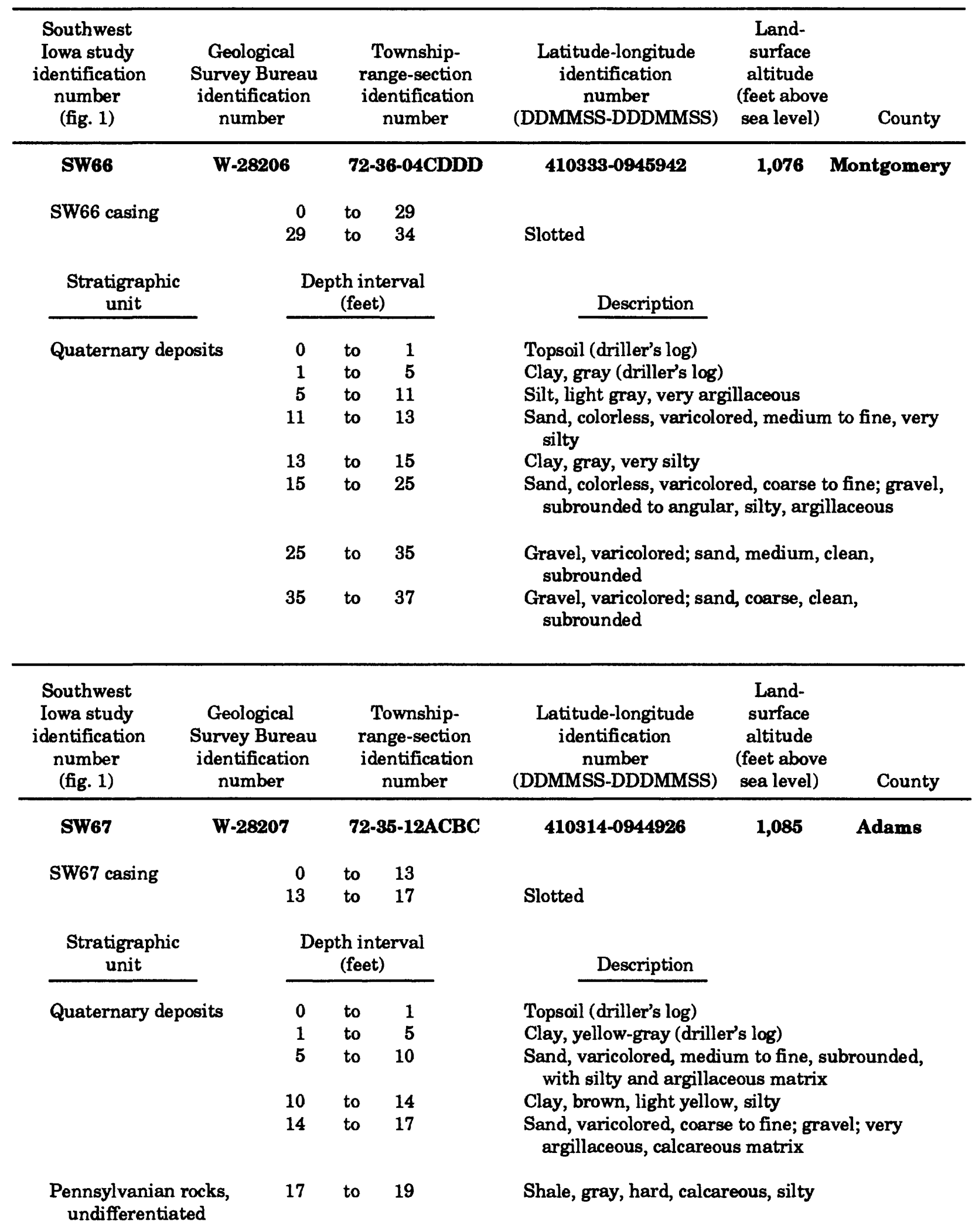


Table 1. Geologic logs of test holes and observation wells drilled in southwest Iowa, 1985-87--Continued

\begin{tabular}{|c|c|c|c|c|c|c|c|}
\hline \multirow{2}{*}{$\begin{array}{c}\begin{array}{c}\text { Southwest } \\
\text { Iowa study } \\
\text { identification } \\
\text { number } \\
\text { (fig. 1) }\end{array} \\
\text { SW68 }\end{array}$} & \multicolumn{2}{|c|}{$\begin{array}{c}\text { Geological } \\
\text { Survey Bureau } \\
\text { identification } \\
\text { number }\end{array}$} & \multicolumn{2}{|c|}{$\begin{array}{l}\text { Township- } \\
\text { range-section } \\
\text { identification } \\
\text { number }\end{array}$} & $\begin{array}{c}\text { Latitude-longitude } \\
\text { identification } \\
\text { number } \\
\text { (DDMMSS-DDDMMSS) }\end{array}$ & $\begin{array}{l}\text { Land- } \\
\text { surface } \\
\text { altitude } \\
\text { (feet above } \\
\text { sea level) }\end{array}$ & County \\
\hline & $\mathbf{W}-\mathbf{2}$ & 205 & & -34-22ABAB & 411215-0944419 & 1,328 & Cass \\
\hline \multirow{2}{*}{\multicolumn{2}{|c|}{$\begin{array}{c}\text { Stratigraphic } \\
\text { unit }\end{array}$}} & \multicolumn{3}{|c|}{$\begin{array}{l}\text { Depth interval } \\
\text { (feet) }\end{array}$} & Description & & \\
\hline & & 0 & to & 15 & \multicolumn{3}{|c|}{ Roadbed and fill (driller's log) } \\
\hline \multirow{24}{*}{\multicolumn{2}{|c|}{ Pleistocene deposits }} & 15 & to & 20 & \multirow{5}{*}{\multicolumn{3}{|c|}{$\begin{array}{l}\text { Till, bright yellow-orange, oxidized, leached } \\
\text { Till, light yellow, oxidized, unleached } \\
\text { Till, yellow, oxidized, unleached } \\
\text { Till, gray, orange mottling, oxidized, unleached } \\
\text { Till, yellow, very light gray mottling, oxidized, } \\
\text { unleached }\end{array}$}} \\
\hline & & 20 & to & 40 & & & \\
\hline & & 40 & to & 46 & & & \\
\hline & & 46 & to & 48 & & & \\
\hline & & 48 & to & 52 & & & \\
\hline & & 52 & to & 60 & \multicolumn{3}{|l|}{ Clay, light gray } \\
\hline & & 60 & to & 64 & \multicolumn{3}{|c|}{ Till, very light gray, unoxidized, unleached } \\
\hline & & 64 & to & 66 & \multicolumn{3}{|c|}{ Till, yellow, orange, oxidized, unleached } \\
\hline & & 66 & to & 80 & \multicolumn{3}{|c|}{ Till, very pale yellow, oxidized, unleached } \\
\hline & & 80 & to & 105 & \multicolumn{3}{|c|}{ Till, light yellow, oxidized, unleached } \\
\hline & & 105 & to & 110 & \multicolumn{3}{|c|}{ Till, very light yellow, unoxidized, unleached } \\
\hline & & 110 & to & 114 & \multicolumn{3}{|c|}{$\begin{array}{l}\text { Till, very light yellow, unoxidized, unleached; clay, } \\
\text { light gray }\end{array}$} \\
\hline & & 114 & to & 115 & \multicolumn{3}{|c|}{ Clay, light gray, slightly calcareous } \\
\hline & & 115 & to & 117 & \multicolumn{3}{|c|}{ Clay, light yellow, slightly calcareous } \\
\hline & & 117 & to & 120 & \multirow{2}{*}{\multicolumn{3}{|c|}{ Till, very light yellow-gray, oxidized, unleached }} \\
\hline & & 120 & to & 147 & & & Till, light yellow, oxidized, unleached \\
\hline & & 147 & to & 155 & \multicolumn{3}{|c|}{$\begin{array}{l}\text { Sand, colorless, dark, medium to fine, subrounded, } \\
\text { with argillaceous, calcareous cement }\end{array}$} \\
\hline & & 155 & to & 160 & \multicolumn{3}{|c|}{$\begin{array}{l}\text { Till, olive-gray and orange, partly oxidized, } \\
\text { unleached }\end{array}$} \\
\hline & & 160 & to & 164 & \multirow{2}{*}{\multicolumn{3}{|c|}{$\begin{array}{l}\text { Till, orange and gray, partly oxidized, unleached } \\
\text { Till, olive-gray and orange, partly oxidized, } \\
\text { unleached }\end{array}$}} \\
\hline & & 164 & to & 170 & & & \\
\hline & & 170 & to & 180 & \multirow{4}{*}{\multicolumn{3}{|c|}{$\begin{array}{l}\text { Till, very light gray, unoxidized, unleached } \\
\text { Till, light gray, sandy, gravelly, slightly calcareous } \\
\text { Till, very light yellow, oxidized, unleached } \\
\text { Till, light yellow, very light gray, very argillaceous, } \\
\text { oxidized, unleached }\end{array}$}} \\
\hline & & 180 & to & 195 & & & \\
\hline & & 195 & to & 199 & & & \\
\hline & & 199 & to & 203 & & & \\
\hline \multicolumn{2}{|c|}{$\begin{array}{l}\text { Pennsylvanian rocks, } \\
\text { undifferentiated }\end{array}$} & 203 & to & 208 & \multicolumn{3}{|c|}{ Limestone, very light yellow, silt-grade } \\
\hline
\end{tabular}


Table 1. Geologic logs of test holes and observation wells drilled in southwest Iowa, 1985-87--Continued

\begin{tabular}{|c|c|c|c|c|c|c|c|}
\hline \multirow{2}{*}{$\begin{array}{c}\begin{array}{c}\text { Southwest } \\
\text { Iowa study } \\
\text { identification } \\
\text { number } \\
\text { (fig. 1) }\end{array} \\
\text { SW69 }\end{array}$} & \multicolumn{2}{|c|}{$\begin{array}{l}\text { Geological } \\
\text { Survey Bureau } \\
\text { identification } \\
\text { number }\end{array}$} & \multicolumn{2}{|c|}{$\begin{array}{l}\text { Township- } \\
\text { range-section } \\
\text { identification } \\
\text { number }\end{array}$} & $\begin{array}{c}\text { Latitude-longitude } \\
\text { identification } \\
\text { number } \\
\text { (DDMMSS-DDDMMSS) }\end{array}$ & \multirow{2}{*}{$\begin{array}{c}\begin{array}{c}\text { Land- } \\
\text { surface } \\
\text { altitude } \\
\text { (feet above } \\
\text { sea level) }\end{array} \\
\mathbf{1 , 3 1 5}\end{array}$} & \multirow{2}{*}{$\frac{\text { County }}{\text { Adair }}$} \\
\hline & & & & 32-28CCCD & 412555-0943242 & & \\
\hline \multirow{2}{*}{\multicolumn{2}{|c|}{$\begin{array}{l}\text { Stratigraphic } \\
\text { unit }\end{array}$}} & \multicolumn{3}{|c|}{$\begin{array}{l}\text { Depth interval } \\
\text { (feet) }\end{array}$} & Description & & \\
\hline & & 0 & to & 3 & Roadbed (driller's log) & & \\
\hline \multirow{7}{*}{\multicolumn{2}{|c|}{ Quaternary deposits }} & 3 & to & 6 & \multirow{7}{*}{\multicolumn{3}{|c|}{$\begin{array}{l}\text { Clay, black (driller's log) } \\
\text { Clay, dark gray to gray (driller's log) } \\
\text { Clay, medium light gray, silty } \\
\text { Clay, gray, slightly silty } \\
\text { Silt, yellow and orange, very argillaceous } \\
\text { Silt, light yellow and orange, very argillaceous } \\
\text { Gravel; sand, varicolored, medium, subrounded, } \\
\quad \text { with silty, argillaceous, calcareous matrix }\end{array}$}} \\
\hline & & 6 & to & 8 & & & \\
\hline & & 8 & to & 11 & & & \\
\hline & & 11 & to & 16 & & & \\
\hline & & 16 & to & 20 & & & \\
\hline & & 20 & to & 24 & & & \\
\hline & & 24 & to & 28 & & & \\
\hline \multirow{19}{*}{\multicolumn{2}{|c|}{ Pleistocene deposits }} & 28 & to & 40 & \multirow{2}{*}{\multicolumn{3}{|c|}{$\begin{array}{l}\text { Till, gray, yellow, partly oxidized, unleached } \\
\text { Gravel, varicolored; sand, medium, subrounded, } \\
\text { partly dolomitic, with till-like matrix }\end{array}$}} \\
\hline & & 40 & to & 57 & & & \\
\hline & & 57 & to & 70 & \multicolumn{3}{|c|}{$\begin{array}{l}\text { Till, gray, unoxidized, unleached; gravel, } \\
\text { varicolored; sand, medium subrounded, partly } \\
\text { dolomitic, with till-like matrix }\end{array}$} \\
\hline & & 70 & to & 80 & \multirow{2}{*}{\multicolumn{3}{|c|}{$\begin{array}{l}\text { Till, gray, unoxidized, unleached, very gravelly } \\
\text { Till, light yellow-orange, gray, partly oxidized, } \\
\text { unleached }\end{array}$}} \\
\hline & & 80 & to & 100 & & & \\
\hline & & 100 & to & 110 & \multicolumn{3}{|c|}{$\begin{array}{l}\text { Till, light yellow-orange, gray, partly oxidized, } \\
\text { unleached, gravelly }\end{array}$} \\
\hline & & 110 & to & 120 & \multicolumn{3}{|c|}{ Till, yellow, light gray, oxidized, unleached } \\
\hline & & 120 & to & 135 & \multicolumn{3}{|c|}{ Till, light yellow, oxidized, unleached } \\
\hline & & 135 & to & 150 & \multicolumn{3}{|c|}{$\begin{array}{l}\text { Till, light yellow, oxidized, unleached; till, medium } \\
\text { light gray, unoxidized, unleached till }\end{array}$} \\
\hline & & 150 & to & 160 & \multicolumn{3}{|c|}{ Till, medium light gray, unoxidized, unleached } \\
\hline & & 160 & to & 174 & \multicolumn{3}{|c|}{ Till, yellow, mottled, oxidized, unleached } \\
\hline & & 174 & to & 180 & \multicolumn{3}{|c|}{ Till, yellow, oxidized, unleached } \\
\hline & & 180 & to & 189 & \multicolumn{3}{|c|}{ Till, yellow, oxidized, unleached, sandy } \\
\hline & & 189 & to & 203 & \multicolumn{3}{|c|}{$\begin{array}{l}\text { Till, medium light gray, unoxidized, unleached; till, } \\
\text { light yellow, oxidized, unleached }\end{array}$} \\
\hline & & 203 & to & 220 & \multicolumn{3}{|c|}{$\begin{array}{l}\text { Sand, colorless, yellow, orange, dark, heavy, fine } \\
\text { to medium, subrounded to subangular, clean, } \\
\text { quartz, with trace heavy minerals }\end{array}$} \\
\hline & & 220 & to & 239 & \multicolumn{3}{|c|}{$\begin{array}{l}\text { Sand, colorless, yellow, orange, dark, heavy, fine } \\
\text { to medium, subrounded to subangular, clean, } \\
\text { quartz, with trace heavy minerals; gravel, trace } \\
\text { metamorphic rocks }\end{array}$} \\
\hline & & 239 & to & 243 & \multirow{2}{*}{\multicolumn{3}{|c|}{$\begin{array}{l}\text { Sandstone; gravel, quartz, metamorphic rocks } \\
\text { Gravel, subrounded to angular; sand, medium; } \\
\text { much till, orange }\end{array}$}} \\
\hline & & 243 & to & 250 & & & \\
\hline & & 250 & to & 252 & \multicolumn{3}{|c|}{$\begin{array}{l}\text { Gravel, subrounded to angular; sand, medium; } \\
\text { with Inoceramus fragments }\end{array}$} \\
\hline
\end{tabular}


Table 1. Geologic logs of test holes and observation wells drilled in southwest Iowa, 1985-87--Continued

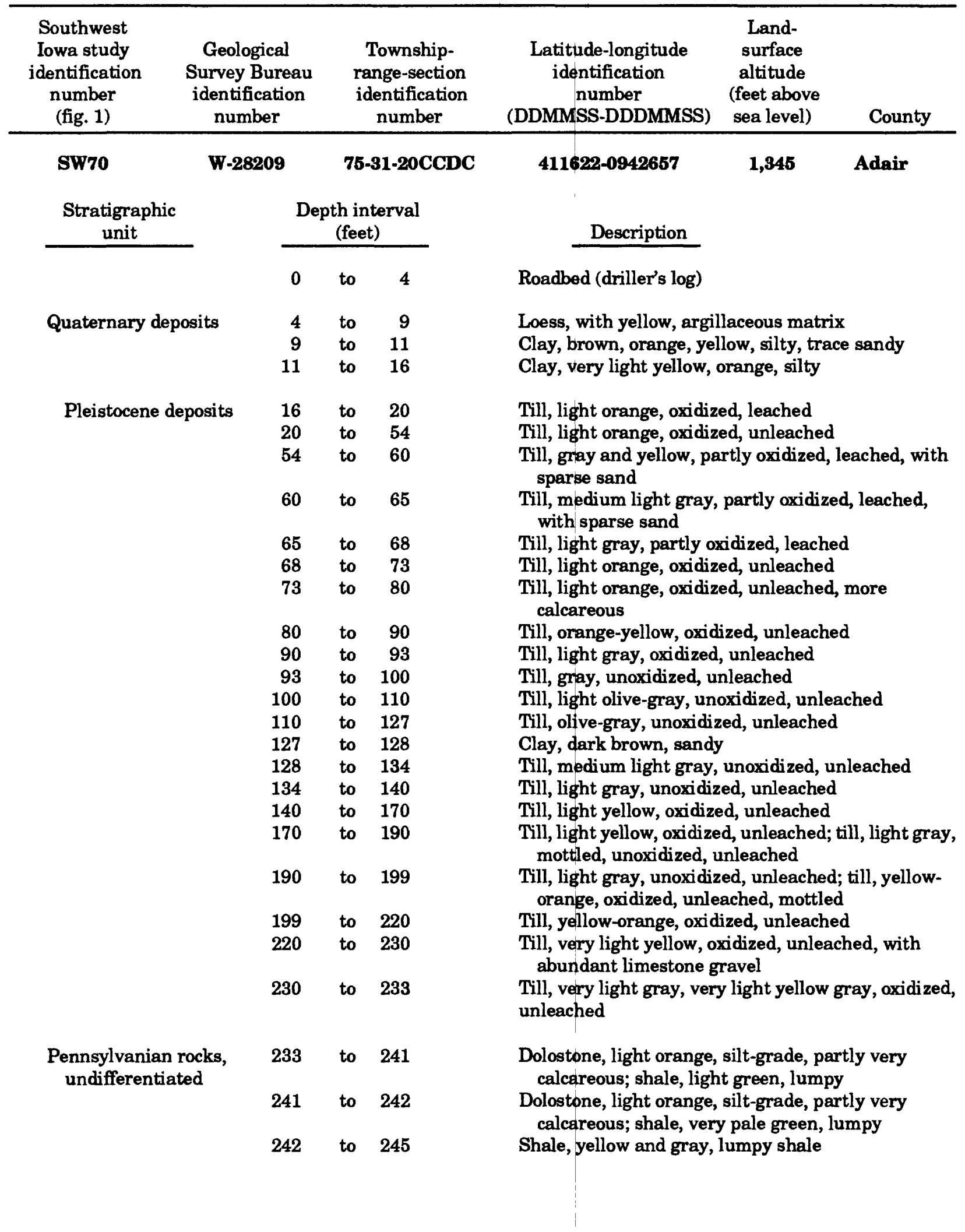


Table 1. Geologic logs of test holes and observation wells drilled in southwest Iowa, 1985-87--Continued

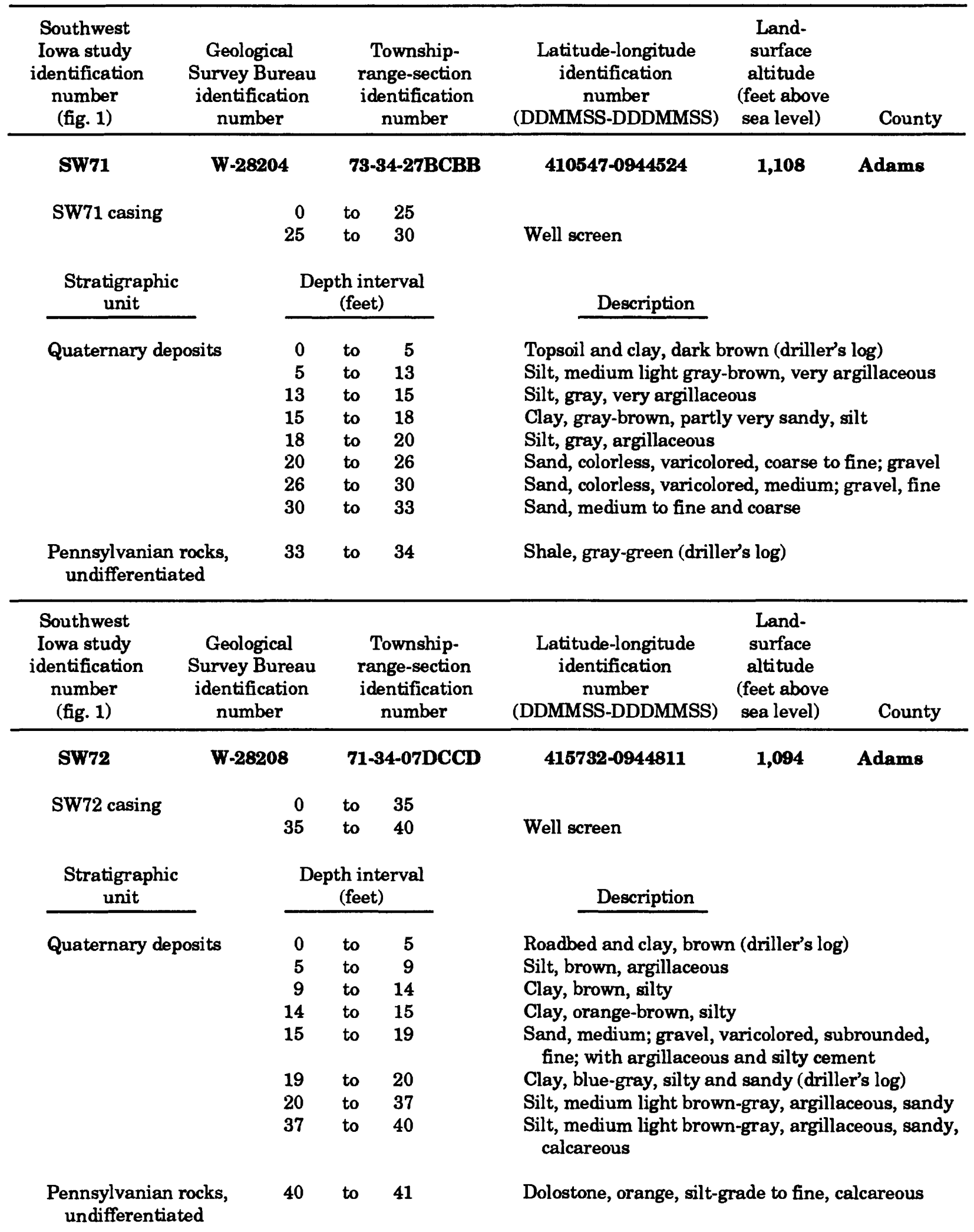


Table 1. Geologic logs of test holes and observation wells drilled in southwest Iowa, 1985-87--Continued

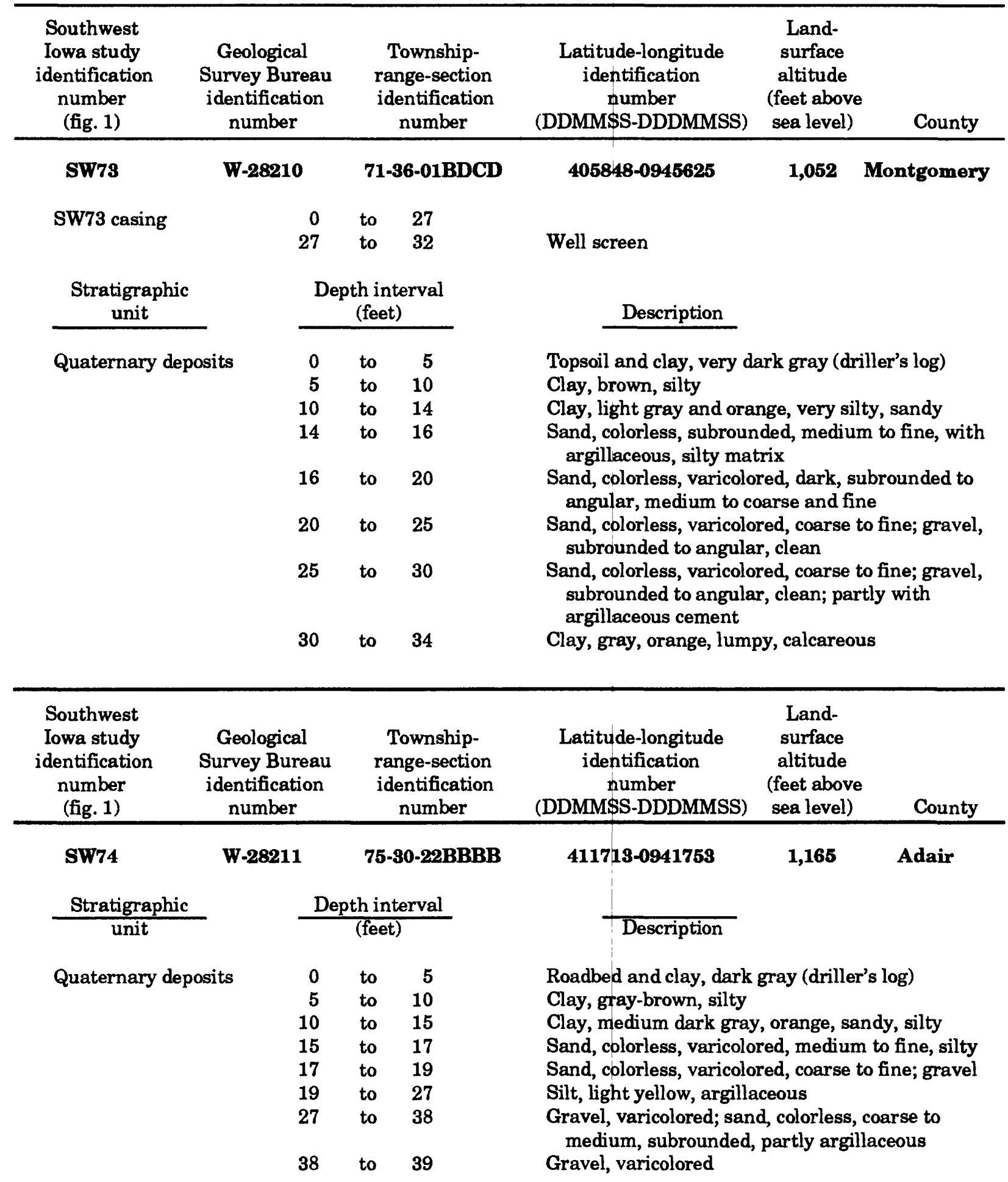


Table 1. Geologic logs of test holes and observation wells drilled in southwest Iowa, 1985-87--Continued

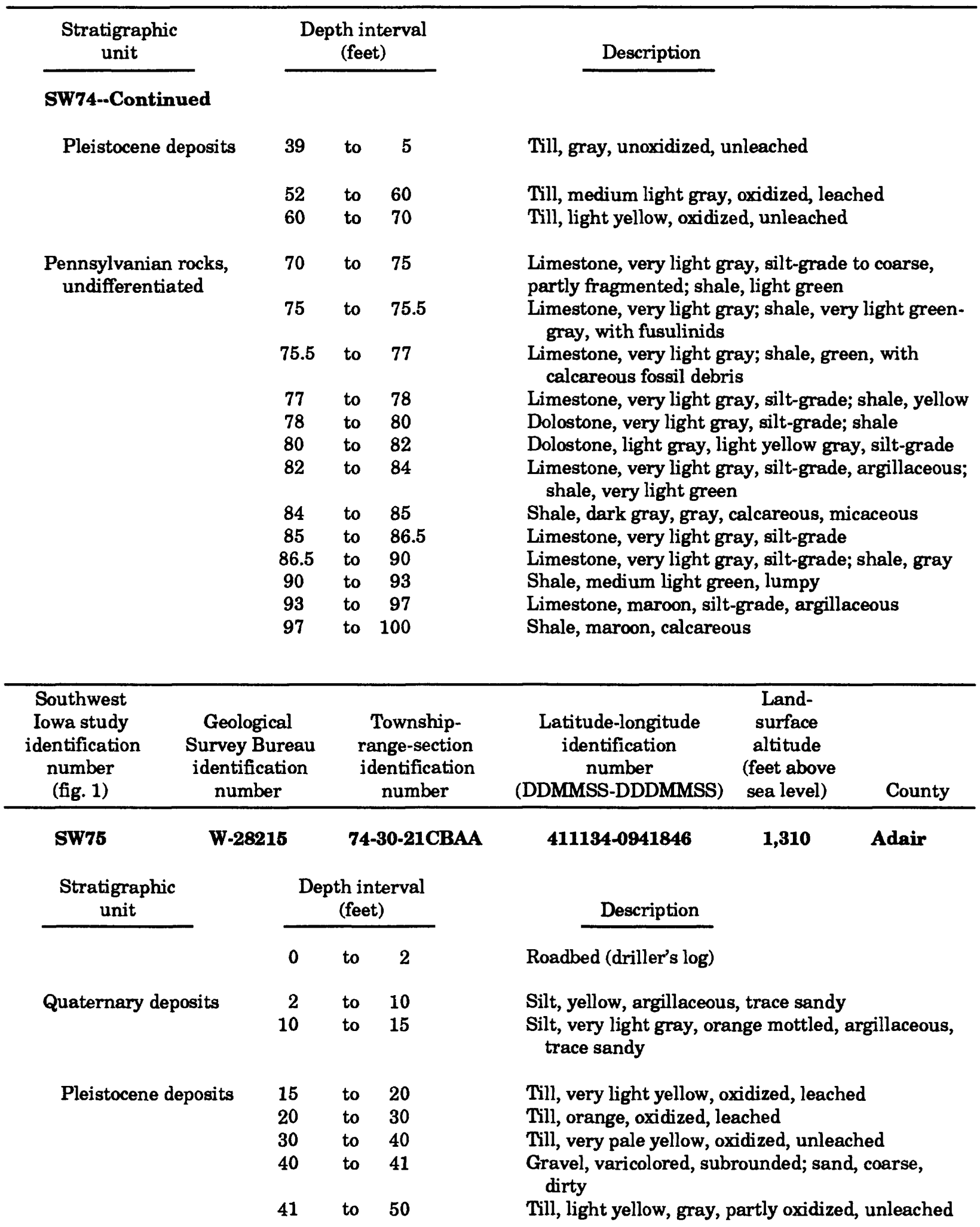


Table 1. Geologic logs of test holes and observation wells drilled in southwest Iowa, 1985-87--Continued

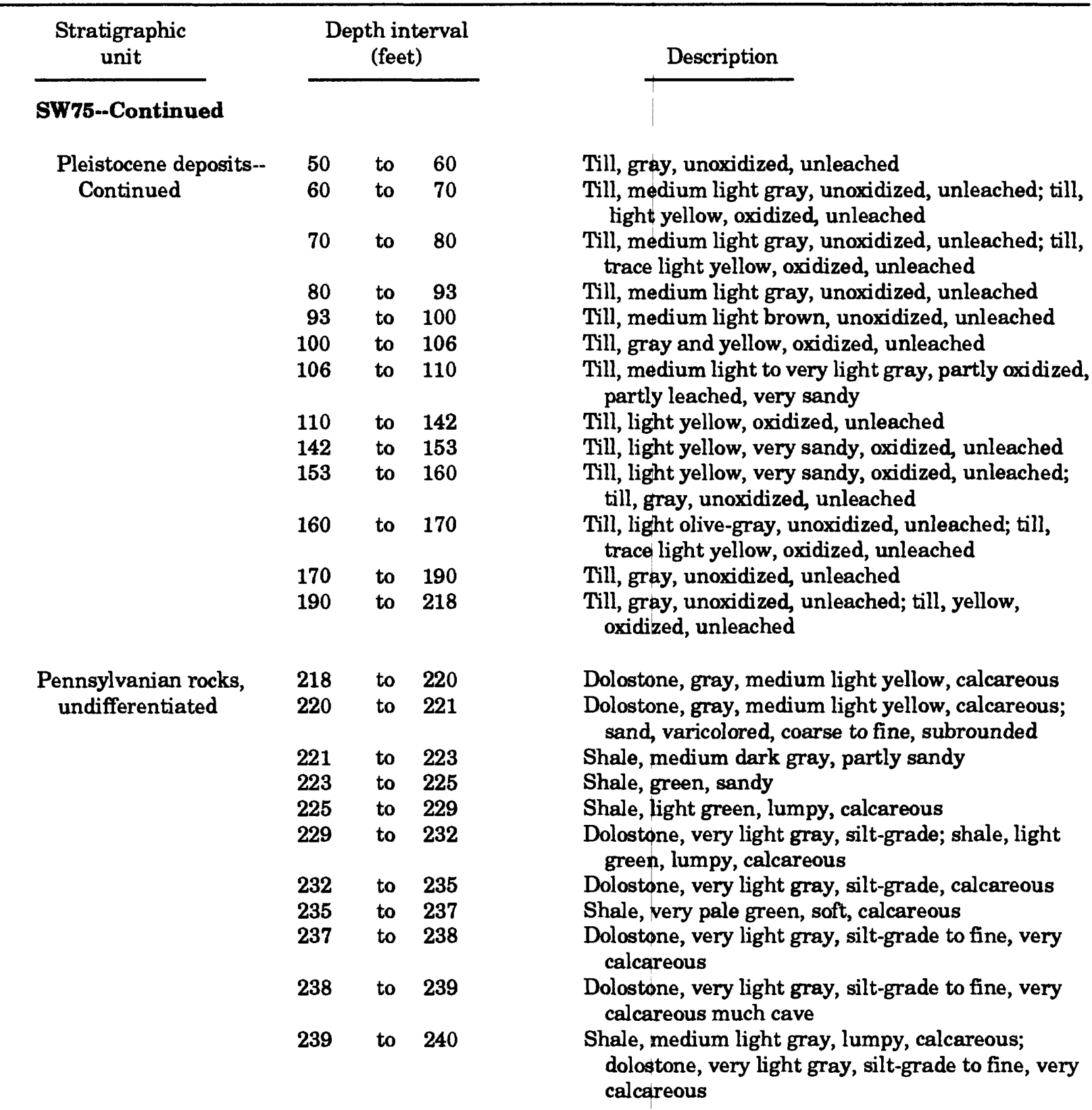


Table 1. Geologic logs of test holes and observation wells drilled in southwest lowa, 1985-87--Continued

\begin{tabular}{|c|c|c|c|c|c|c|c|}
\hline \multirow{2}{*}{$\begin{array}{c}\begin{array}{c}\text { Southwest } \\
\text { Iowa study } \\
\text { identification } \\
\text { number } \\
\text { (fig. 1) }\end{array} \\
\text { SW76 }\end{array}$} & \multicolumn{2}{|c|}{$\begin{array}{c}\text { Geological } \\
\text { Survey Bureau } \\
\text { identification } \\
\text { number }\end{array}$} & \multicolumn{2}{|c|}{$\begin{array}{l}\text { Township- } \\
\text { range-section } \\
\text { identification } \\
\text { number }\end{array}$} & \multirow{2}{*}{$\begin{array}{c}\begin{array}{c}\text { Latitude-longitude } \\
\text { identification } \\
\text { number }\end{array} \\
\text { (DDMMSS-DDDMMSS) } \\
\mathbf{4 1 0 8 1 6 - 0 9 4 3 6 5 0}\end{array}$} & $\begin{array}{l}\text { Land- } \\
\text { surface } \\
\text { altitude } \\
\text { (feet above } \\
\text { sea level) }\end{array}$ & \multirow{2}{*}{$\frac{\text { County }}{\text { Adams }}$} \\
\hline & & & & 33-11BDDA & & 1,274 & \\
\hline \multirow{2}{*}{\multicolumn{2}{|c|}{$\begin{array}{l}\text { Stratigraphic } \\
\text { unit }\end{array}$}} & \multicolumn{3}{|c|}{$\begin{array}{l}\text { Depth interval } \\
\text { (feet) }\end{array}$} & Description & & \\
\hline & & 0 & to & 5 & Roadbed (driller's log) & & \\
\hline \multirow{23}{*}{\multicolumn{2}{|c|}{ Quaternary deposits }} & 5 & to & 9 & \\
\hline & & 9 & to & 13 & \multirow{2}{*}{\multicolumn{3}{|c|}{ Clay, yellow-orange, silty }} \\
\hline & & 13 & to & 17 & & & \\
\hline & & 17 & to & 19 & \multirow{3}{*}{\multicolumn{3}{|c|}{$\begin{array}{l}\text { Clay, light gray with orange mottling, trace sandy } \\
\text { Till, light yellow-orange, oxidized, unleached } \\
\text { Till, medium light yellow-orange, oxidized, } \\
\text { unleached }\end{array}$}} \\
\hline & & 19 & to & 39 & & & \\
\hline & & 39 & to & 50 & & & \\
\hline & & 50 & to & 60 & \multirow{2}{*}{\multicolumn{3}{|c|}{$\begin{array}{l}\text { Till, pale light yellow-gray, oxidized, unleached } \\
\text { Till, medium light gray, oxidized, unleached }\end{array}$}} \\
\hline & & 60 & to & 90 & & & \\
\hline & & 90 & & 99 & \multicolumn{3}{|c|}{ Till, medium light gray, unoxidized, unleached } \\
\hline & & 99 & to & 102 & \multirow{2}{*}{\multicolumn{3}{|c|}{$\begin{array}{l}\text { Till, light olive-gray, unoxidized, unleached } \\
\text { Till, medium light brown, unoxidized, unleached }\end{array}$}} \\
\hline & & 102 & to & 111 & & & \\
\hline & & 111 & to & 114 & \multicolumn{3}{|c|}{ Till, very light brown, unoxidized, unleached } \\
\hline & & 114 & to & 117 & \multicolumn{3}{|c|}{ Till, pale yellow, oxidized, unleached } \\
\hline & & 117 & to & 120 & \multicolumn{3}{|c|}{ Till, medium light gray, oxidized, unleached } \\
\hline & & 120 & to & 138 & \multicolumn{3}{|c|}{ Till, pale yellow-orange, oxidized, unleached } \\
\hline & & 138 & to & 145 & \multicolumn{3}{|c|}{$\begin{array}{l}\text { Till, pale yellow-orange, oxidized, unleached, } \\
\text { sandy }\end{array}$} \\
\hline & & 145 & to & 160 & \multirow{2}{*}{\multicolumn{3}{|c|}{$\begin{array}{l}\text { Till, medium light gray, unoxidized, unleached } \\
\text { Till, medium light gray, unoxidized, unleached; till, } \\
\text { trace yellow, oxidized, unleached }\end{array}$}} \\
\hline & & 160 & to & 170 & & & \\
\hline & & 170 & to & 260 & \multicolumn{3}{|c|}{ Till, light olive-gray, unoxidized, unleached } \\
\hline & & 260 & to & 280 & \multicolumn{3}{|c|}{$\begin{array}{l}\text { Gravel, varicolored, subrounded, quartz, } \\
\text { metamorphic, and limestone rocks, with till-like } \\
\text { matrix; till, light olive-gray, unoxidized, } \\
\text { unleached }\end{array}$} \\
\hline & & 280 & to & 300 & \multicolumn{3}{|c|}{$\begin{array}{l}\text { Gravel, varicolored, subrounded, quartz, } \\
\text { metamorphic, and limestone rocks, with till-like } \\
\text { matrix; till, light olive-gray, unoxidized, } \\
\text { unleached; sand, medium }\end{array}$} \\
\hline & & 300 & to & 320 & \multicolumn{3}{|c|}{$\begin{array}{l}\text { Gravel, varicolored, subrounded, quartz, } \\
\text { metamorphic, and limestone rocks, with till-like } \\
\text { matrix; till, light olive-gray, unoxidized, } \\
\text { unleached; sand, partly subangular }\end{array}$} \\
\hline & & 320 & to & 329 & \multicolumn{3}{|c|}{$\begin{array}{l}\text { Gravel, varicolored, subrounded, quartz, } \\
\text { metamorphic, and limestone rocks, with till-like } \\
\text { matrix }\end{array}$} \\
\hline $\begin{array}{r}\text { Pennsylvani } \\
\text { undifferen }\end{array}$ & $\begin{array}{l}\text { rocks, } \\
\text { ted }\end{array}$ & 329 & to & 340 & \multicolumn{3}{|c|}{$\begin{array}{l}\text { Shale, gray; possible limestone layer at top } \\
\text { (driller's log) }\end{array}$} \\
\hline
\end{tabular}


Table 1. Geologic logs of test holes and observation wells drilled in southwest lowa, 1985-87--Continued

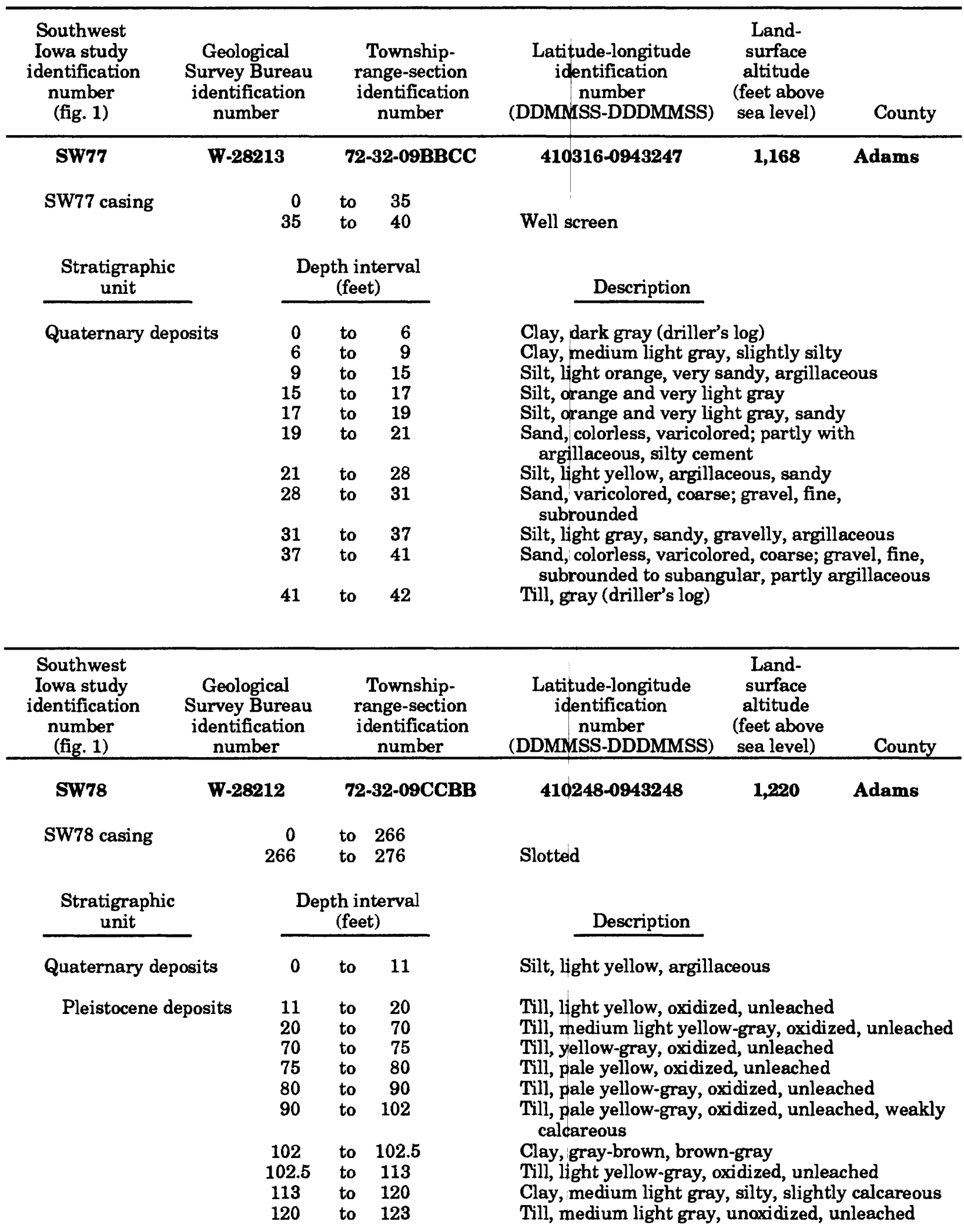


Table 1. Geologic logs of test holes and observation wells drilled in southwest Iowa, 1985-87--Continued

\begin{tabular}{|c|c|c|c|c|c|c|c|}
\hline \multicolumn{2}{|c|}{$\begin{array}{l}\text { Stratigraphic } \\
\text { unit }\end{array}$} & \multicolumn{3}{|c|}{$\begin{array}{l}\text { Depth interval } \\
\text { (feet) }\end{array}$} & Description & & \\
\hline \multicolumn{8}{|c|}{ SW78--Continued } \\
\hline \multirow{7}{*}{\multicolumn{2}{|c|}{$\begin{array}{l}\text { Pleistocene deposits-- } \\
\text { Continued }\end{array}$}} & 123 & & 132 & \multicolumn{3}{|c|}{$\begin{array}{l}\text { Gravel, colorless, varicolored, quartz and } \\
\text { metamorphic rock; sand, coarse, subrounded, } \\
\text { dirty, quartz }\end{array}$} \\
\hline & & 132 & to & 240 & \multirow{3}{*}{\multicolumn{3}{|c|}{$\begin{array}{l}\text { Till, light olive-gray, unoxidized, unleached } \\
\text { Till, medium light gray, unoxidized, unleached } \\
\text { Till, medium light gray, unoxidized, unleached, } \\
\text { gravelly }\end{array}$}} \\
\hline & & 240 & & 244 & & & \\
\hline & & 244 & to & 251 & & & \\
\hline & & 251 & to & 256 & \multicolumn{3}{|c|}{$\begin{array}{l}\text { Till, gray, maroon, partly oxidized, unleached, very } \\
\text { gravelly }\end{array}$} \\
\hline & & 256 & to & 263 & \multirow{2}{*}{\multicolumn{3}{|c|}{$\begin{array}{l}\text { Clay, gray, maroon, calcareous, very sandy } \\
\text { Gravel, varicolored, dirty, quartz, limestone, trace } \\
\text { chert rocks }\end{array}$}} \\
\hline & & 263 & to & 275 & & & \\
\hline \multicolumn{2}{|c|}{$\begin{array}{l}\text { Pennsylvanian rocks, } \\
\text { undifferentiated }\end{array}$} & 275 & to & 279 & \multicolumn{3}{|c|}{$\begin{array}{l}\text { Limestone, very light gray, silt-grade, } \\
\text { sublithographic }\end{array}$} \\
\hline $\begin{array}{l}\text { Southwest } \\
\text { Iowa study } \\
\text { identification } \\
\text { number } \\
\text { (fig. 1) }\end{array}$ & \multicolumn{2}{|c|}{$\begin{array}{l}\text { Geological } \\
\text { Survey Bureau } \\
\text { identification } \\
\text { number }\end{array}$} & \multicolumn{2}{|c|}{$\begin{array}{l}\text { Township- } \\
\text { range-section } \\
\text { identification } \\
\text { number }\end{array}$} & $\begin{array}{l}\text { Latitude-longitude } \\
\text { identification } \\
\text { number } \\
\text { (DDMMSS-DDDMMSS) }\end{array}$ & $\begin{array}{l}\text { Land- } \\
\text { surface } \\
\text { altitude } \\
\text { (feet above } \\
\text { sea level) }\end{array}$ & County \\
\hline SW79 & \multicolumn{2}{|c|}{ W-28652 } & \multicolumn{2}{|c|}{ 70-34-22AAAA } & 405123-0944419 & $\mathbf{1 , 1 5 8}$ & Taylor \\
\hline \multicolumn{2}{|c|}{$\begin{array}{l}\text { Stratigraphic } \\
\text { unit }\end{array}$} & \multicolumn{3}{|c|}{$\begin{array}{l}\text { Depth interval } \\
\text { (feet) }\end{array}$} & Description & & \\
\hline \multirow{11}{*}{\multicolumn{2}{|c|}{ Pleistocene deposits }} & 0 & to & 5 & \multicolumn{3}{|c|}{ Clay, yellow-gray sandy (driller's log) } \\
\hline & & 5 & to & 6 & \multicolumn{3}{|c|}{ Silt; clay, very light gray } \\
\hline & & 6 & to & 7 & \multicolumn{3}{|c|}{$\begin{array}{l}\text { Sand, varicolored, coarse; gravel; silt and clay } \\
\text { matrix }\end{array}$} \\
\hline & & 7 & to & 16 & \multicolumn{3}{|c|}{ Till, pale orange, oxidized, unleached } \\
\hline & & 16 & to & 18 & \multicolumn{3}{|c|}{ Till, light yellow-gray, oxidized, unleached } \\
\hline & & 18 & to & 27 & \multicolumn{3}{|c|}{$\begin{array}{l}\text { Till, light yellow-gray, oxidized, unleached; till, gray, } \\
\text { unoxidized, unleached }\end{array}$} \\
\hline & & 27 & to & 32 & \multicolumn{3}{|c|}{$\begin{array}{l}\text { Till, yellow, oxidized, unleached; till, brown, } \\
\text { unoxidized, unleached }\end{array}$} \\
\hline & & 32 & to & 37 & \multicolumn{3}{|c|}{$\begin{array}{l}\text { Till, yellow, oxidized, unleached; till, gray, } \\
\text { unoxidized, unleached }\end{array}$} \\
\hline & & 37 & to & 40 & \multicolumn{3}{|c|}{$\begin{array}{l}\text { Till, gray, yellow and orange mottling, unoxidized, } \\
\text { unleached }\end{array}$} \\
\hline & & 40 & to & 61 & \multirow{2}{*}{\multicolumn{3}{|c|}{$\begin{array}{l}\text { Till, gray, trace orange, unoxidized, unleached } \\
\text { Silt, very light gray, orange, argillaceous, } \\
\text { calcareous }\end{array}$}} \\
\hline & & 61 & to & 70 & & & \\
\hline \multicolumn{2}{|c|}{$\begin{array}{l}\text { Pennsylvanian rocks, } \\
\text { undifferentiated }\end{array}$} & $\begin{array}{l}70 \\
78\end{array}$ & $\begin{array}{l}\text { to } \\
\text { to }\end{array}$ & $\begin{array}{l}78 \\
81\end{array}$ & \multicolumn{3}{|c|}{$\begin{array}{l}\text { Shale, yellow, silty, blocky, slightly calcareous } \\
\text { Shale, yellow, silty, blocky, slightly calcareous; } \\
\text { limestone, gray }\end{array}$} \\
\hline
\end{tabular}


Table 1. Geologic logs of test holes and observation wells drilled in southwest Iowa, 1985-87--Continued

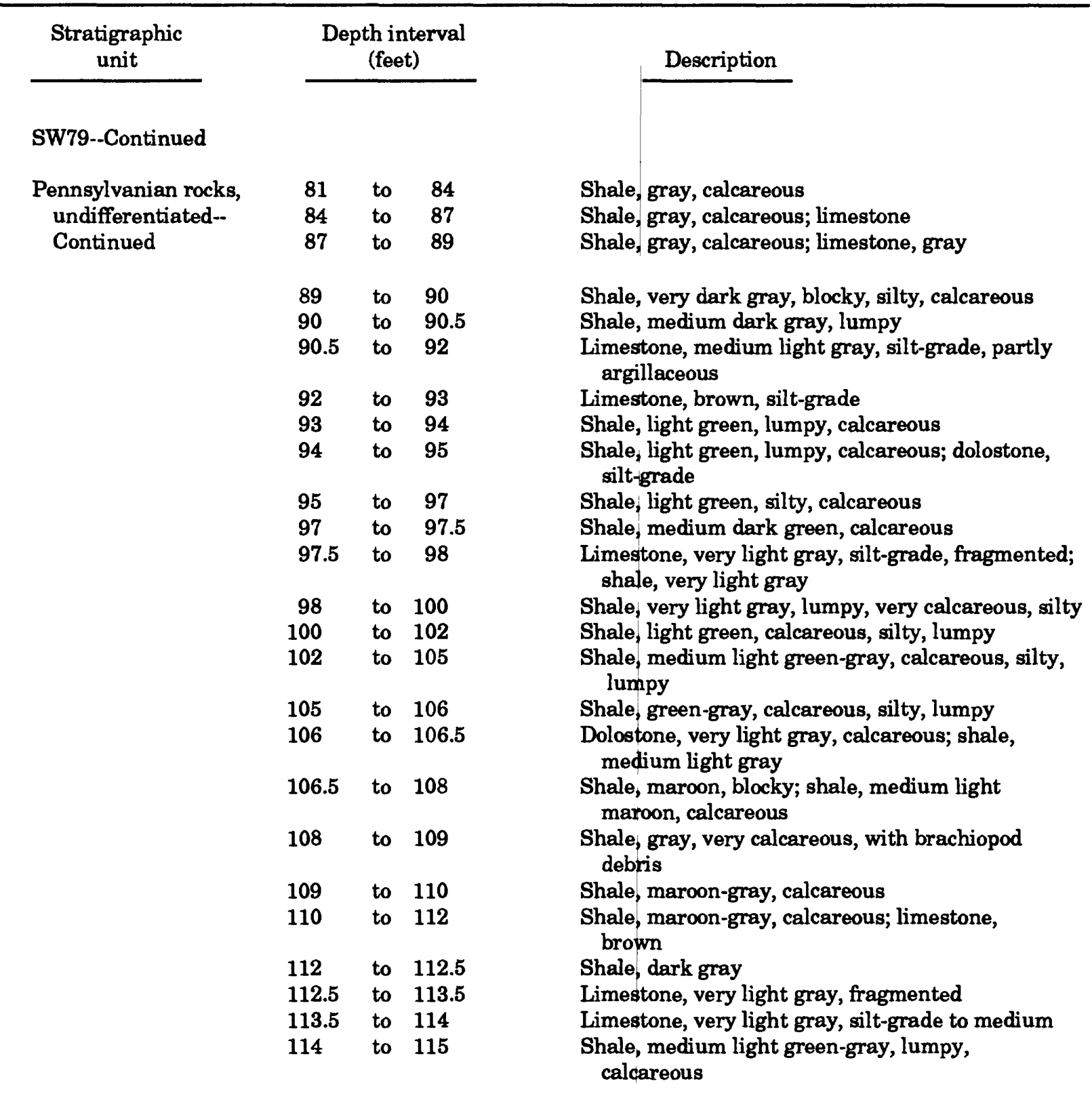


Table 1. Geologic logs of test holes and observation wells drilled in southwest Iowa, 1985-87--Continued

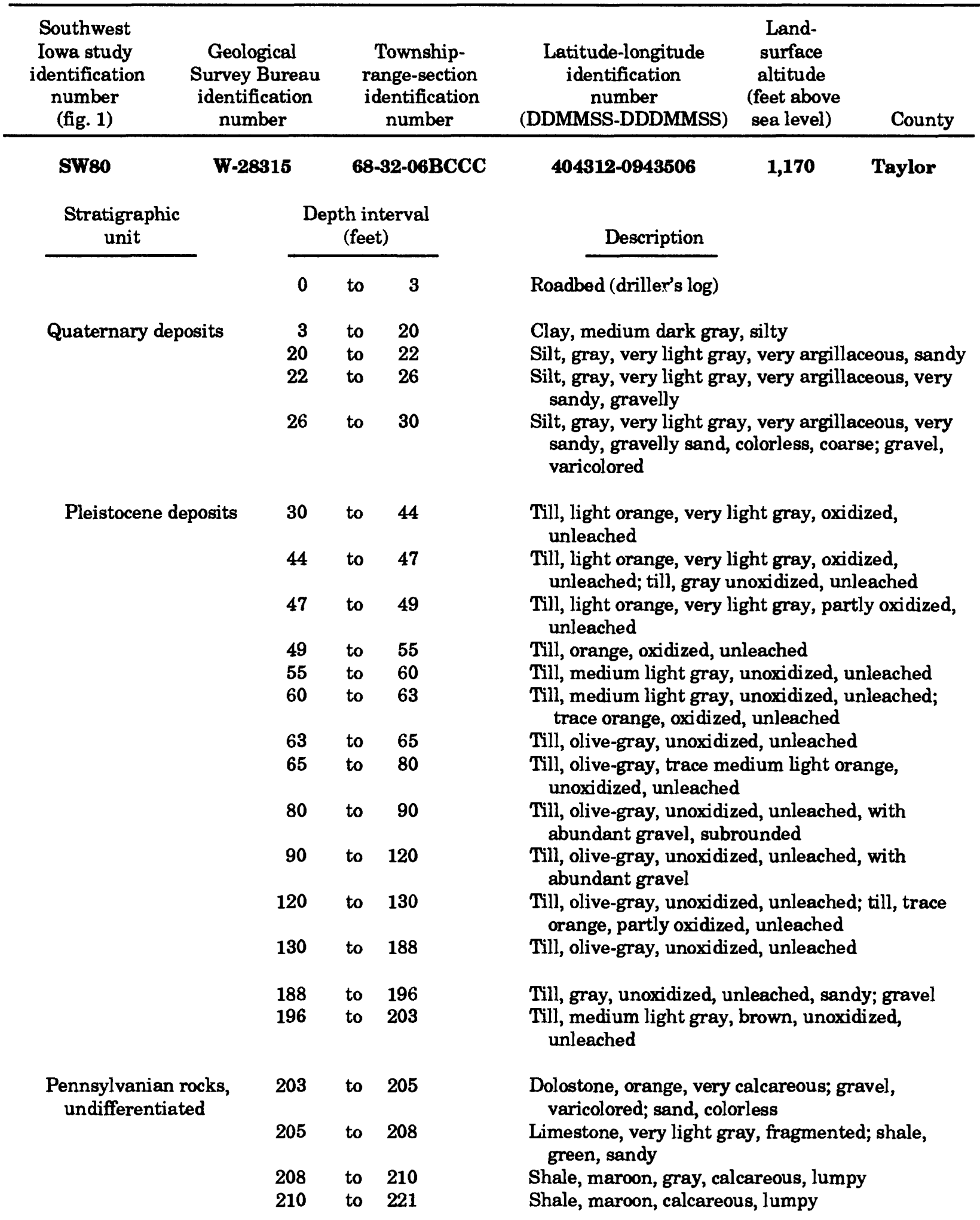


Table 1. Geologic logs of test holes and observation wells drilled in southwest Iowa, 1985-87--Continued

\begin{tabular}{|c|c|c|c|c|c|c|c|}
\hline \multirow{2}{*}{$\begin{array}{c}\begin{array}{c}\text { Southwest } \\
\text { Iowa study } \\
\text { identification } \\
\text { number } \\
\text { (fig. 1) }\end{array} \\
\text { SW81 }\end{array}$} & \multicolumn{2}{|c|}{$\begin{array}{l}\text { Geological } \\
\text { Survey Bureau } \\
\text { identification } \\
\text { number }\end{array}$} & \multicolumn{2}{|c|}{$\begin{array}{l}\text { Township- } \\
\text { range-section } \\
\text { identification } \\
\text { number }\end{array}$} & $\begin{array}{c}\text { Latitude-longitude } \\
\text { identification } \\
\text { number } \\
\text { (DDMMSS-DDDMMSS) }\end{array}$ & $\begin{array}{l}\text { Land- } \\
\text { surface } \\
\text { altitude } \\
\text { (feet above } \\
\text { sea level) }\end{array}$ & County \\
\hline & W-2 & & & 32-11AADD & $403718-0942926$ & 1,077 & Taylor \\
\hline \multirow{2}{*}{\multicolumn{2}{|c|}{$\begin{array}{l}\text { Stratigraphic } \\
\text { unit }\end{array}$}} & \multicolumn{3}{|c|}{$\begin{array}{l}\text { Depth interval } \\
\text { (feet) }\end{array}$} & Description & & \\
\hline & & 0 & to & 4 & Fill (driller's log) & & \\
\hline \multirow{9}{*}{\multicolumn{2}{|c|}{ Quaternary deposits }} & 4 & to & 6 & \multirow{9}{*}{\multicolumn{3}{|c|}{$\begin{array}{l}\text { Clay, gray, silty } \\
\text { Clay, medium light brown-gray, silty } \\
\text { Clay, light yellow with orange mottling, silty } \\
\text { Clay, brown, silty } \\
\text { Clay, orange, very silty } \\
\text { Silt, medium light gray, with trace orange, very } \\
\text { argillaceous } \\
\text { Silt, medium light gray, argillaceous } \\
\text { Sand, colorless, orange, subrounded to } \\
\text { subangular, very argillaceous, silty, medium } \\
\text { to fine } \\
\text { Gravel, colorless, varicolored; sand, fine }\end{array}$}} \\
\hline & & 6 & to & 8 & & & \\
\hline & & 8 & to & 15 & & & \\
\hline & & 15 & to & 16 & & & \\
\hline & & 16 & to & 17 & & & \\
\hline & & 17 & to & 18 & & & \\
\hline & & 18 & to & 20 & & & \\
\hline & & 20 & to & 24 & & & \\
\hline & & 24 & to & 30 & & & \\
\hline \multirow{14}{*}{\multicolumn{2}{|c|}{ Pleistocene deposits }} & 30 & to & 60 & \multirow{8}{*}{\multicolumn{3}{|c|}{$\begin{array}{l}\text { Till, light olive-gray, unoxidized, unleached } \\
\text { Till, gray, unoxidized, unleached } \\
\text { Till, medium dark gray, unoxidized, unleached } \\
\text { Till, gray, unoxidized, unleached } \\
\text { Till, light olive-gray, unoxidized, unleached } \\
\text { Till, medium light gray, unoxidized, unleached } \\
\text { Till, light olive-gray, unoxidized, unleached } \\
\text { Gravel, varicolored; sand, colorless, medium; till, } \\
\text { light olive-gray, unoxidized, unleached }\end{array}$}} \\
\hline & & 60 & to & 72 & & & \\
\hline & & 72 & to & 74 & & & \\
\hline & & 74 & to & 80 & & & \\
\hline & & 80 & to & 110 & & & \\
\hline & & 110 & to & 120 & & & \\
\hline & & 120 & to & 129 & & & \\
\hline & & 129 & to & 140 & & & \\
\hline & & 140 & to & 180 & \multirow{3}{*}{\multicolumn{3}{|c|}{$\begin{array}{l}\text { Till, olive-gray, unoxidized, unleached } \\
\text { Till, light olive-gray, unoxidized, unleached } \\
\text { Till, medium light olive-gray, unoxidized, } \\
\text { unleached }\end{array}$}} \\
\hline & & 180 & to & 200 & & & \\
\hline & & 200 & to & 220 & & & \\
\hline & & 220 & to & 225 & \multirow{2}{*}{\multicolumn{3}{|c|}{$\begin{array}{l}\text { Till, light olive-gray, unoxidized, unleached } \\
\text { Sand, colorless, dark trace varicolored, medium to } \\
\text { fine and coarse, subrounded }\end{array}$}} \\
\hline & & 225 & to & 240 & & & \\
\hline & & 240 & to & 252 & \multicolumn{3}{|c|}{ Till, medium light gray, unoxidized, unleached } \\
\hline \multirow{2}{*}{\multicolumn{2}{|c|}{$\begin{array}{l}\text { Pennsylvanian rocks, } \\
\text { undifferentiated }\end{array}$}} & 252 & to & 260 & \multicolumn{3}{|c|}{$\begin{array}{l}\text { Shale, medium light green, gray, slightly } \\
\text { micaceous }\end{array}$} \\
\hline & & 260 & to & 267 & \multicolumn{3}{|c|}{$\begin{array}{l}\text { Shale, medium light green, gray, slightly } \\
\text { micaceous, unoxidized, unleached }\end{array}$} \\
\hline
\end{tabular}


Table 1. Geologic logs of test holes and observation wells drilled in southwest Iowa, 1985-87--Continued

\begin{tabular}{|c|c|c|c|c|c|c|c|}
\hline \multirow{2}{*}{$\begin{array}{c}\begin{array}{c}\text { Southwest } \\
\text { Iowa study } \\
\text { identification } \\
\text { number } \\
\text { (fig. 1) }\end{array} \\
\text { SW82 }\end{array}$} & \multicolumn{2}{|c|}{$\begin{array}{c}\text { Geological } \\
\text { Survey Bureau } \\
\text { identification } \\
\text { number }\end{array}$} & \multicolumn{2}{|c|}{$\begin{array}{l}\text { Township- } \\
\text { range-section } \\
\text { identification } \\
\text { number }\end{array}$} & \multirow{2}{*}{$\begin{array}{c}\begin{array}{c}\text { Latitude-longitude } \\
\text { identification } \\
\text { number }\end{array} \\
\text { (DDMMSS-DDDMMSS) } \\
\mathbf{4 0 5 5 1 4 - 0 9 4 4 4 1 6}\end{array}$} & \multirow{2}{*}{$\begin{array}{c}\begin{array}{c}\text { Land- } \\
\text { surface } \\
\text { altitude } \\
\text { (feet above } \\
\text { sea level) }\end{array} \\
1,280\end{array}$} & \multirow{2}{*}{$\frac{\text { County }}{\text { Adams }}$} \\
\hline & W-2 & & & 34-26CBBC & & & \\
\hline \multicolumn{2}{|c|}{$\begin{array}{l}\text { Stratigraphic } \\
\text { unit }\end{array}$} & \multicolumn{3}{|c|}{$\begin{array}{l}\text { Depth interval } \\
\quad \text { (feet) }\end{array}$} & Description & & \\
\hline \multicolumn{2}{|c|}{ Quaternary deposits } & 0 & to & 2 & \multicolumn{3}{|c|}{ Fill and topsoil (driller's log) } \\
\hline \multirow{13}{*}{\multicolumn{2}{|c|}{ Pleistocene deposits }} & 2 & to & 8 & \\
\hline & & 8 & to & 10 & \multicolumn{3}{|c|}{ Clay, gray to yellow-gray (driller's log) } \\
\hline & & 10 & to & 19 & \multicolumn{3}{|c|}{ Clay, yellow-gray (driller's log) } \\
\hline & & 19 & to & 38 & \multirow{2}{*}{\multicolumn{3}{|c|}{ Till, yellow-orange and yellow-gray (driller's log) }} \\
\hline & & 38 & to & 55 & & & \\
\hline & & $\mathbf{5 5}$ & to & 62 & \multicolumn{3}{|c|}{$\begin{array}{l}\text { Grading to till, yellow-brown and yellow-gray } \\
\text { (driller's log) }\end{array}$} \\
\hline & & 62 & to & 78 & \multicolumn{3}{|c|}{ Till, yellow-brown (driller's log) } \\
\hline & & 78 & to & 81 & \multicolumn{3}{|c|}{ Till, grading to till, blue-gray (driller's log) } \\
\hline & & 81 & to & 86 & \multicolumn{3}{|c|}{ Till, blue-gray (driller's log) } \\
\hline & & 86 & to & 101 & \multicolumn{3}{|c|}{ Till, blue-gray and yellow-brown (driller's log) } \\
\hline & & 101 & to & 104 & \multicolumn{3}{|l|}{ Till (driller's log) } \\
\hline & & 104 & to & 150 & \multicolumn{3}{|c|}{ Till, yellow-brown (driller's log) } \\
\hline & & 150 & to & 165 & \multicolumn{3}{|c|}{ Till, blue-gray (driller's log) } \\
\hline
\end{tabular}

Note: This is a core reposited at the Iowa Department of Natural Resources, Geological Survey Bureau.

\begin{tabular}{|c|c|c|c|c|c|}
\hline $\begin{array}{c}\text { Southwest } \\
\text { Iowa study } \\
\text { identification } \\
\text { number } \\
\text { (fig. 1) }\end{array}$ & $\begin{array}{c}\text { Geological } \\
\text { Survey Bureau } \\
\text { identification } \\
\text { number }\end{array}$ & $\begin{array}{l}\text { Township- } \\
\text { range-section } \\
\text { identification } \\
\text { number }\end{array}$ & $\begin{array}{c}\text { Latitude-longitude } \\
\text { identification } \\
\text { number } \\
\text { (DDMMSS-DDDMMSS) }\end{array}$ & $\begin{array}{c}\text { Land- } \\
\text { surface } \\
\text { altitude } \\
\text { (feet above } \\
\text { sea level) }\end{array}$ & County \\
\hline SW83 & W-28318 & 72-32-09CCBB & $410248-0943248$ & 1,220 & Adams \\
\hline SW83 casing & $\begin{array}{r}0 \\
130\end{array}$ & $\begin{array}{ll}\text { to } & 130 \\
\text { to } & 136\end{array}$ & Slotted & & \\
\hline
\end{tabular}

Same location as SW78, see log for SW78 for description. 
Table 1. Geologic logs of test holes and observation wells drilled in southwest lowa, 1985-87--Continued

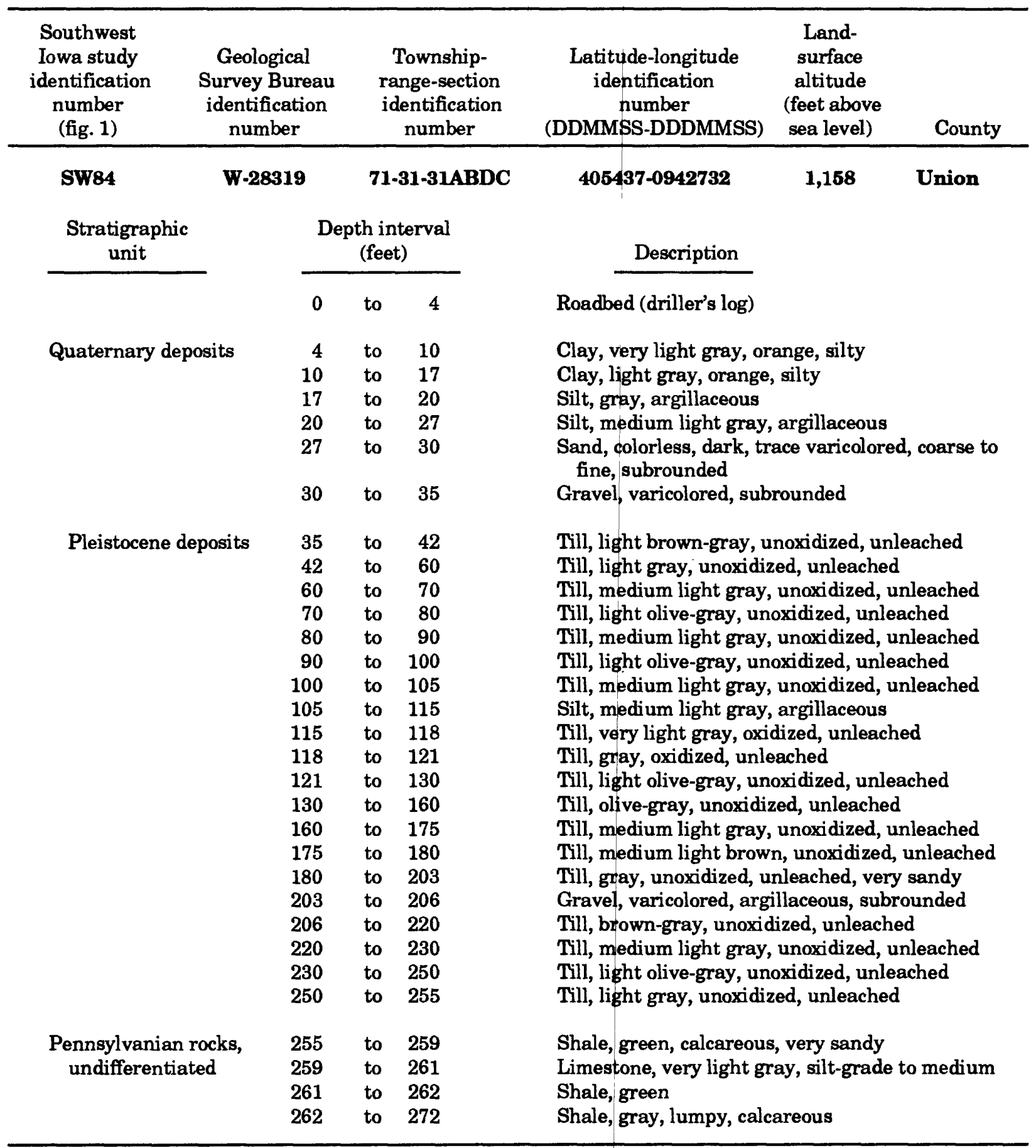


Table 2. Ranges of hydraulic conductivity of selected earth materials (modified from Freeze and Cherry, 1979)

[ft/d, feet per day; >, greater than; <, less than]

\begin{tabular}{lccc}
\hline \multicolumn{1}{c}{ Material } & $\begin{array}{c}\text { Hydraulic conductivity } \\
\text { (ft/d) }\end{array}$ \\
& Unconsolidated material & & \\
& & & \\
Glacial till & 0.00000011 & to & 1.1 \\
Silt, loess & .0011 & to & 13 \\
Silty sand & .1 & to & 650 \\
Clean sand & 1.5 & to & 6,700 \\
Gravel & 650 & to & $>150,000$ \\
& & & \\
& Bedrock & & \\
Shale & $<.000000067$ & to & .00067 \\
Limestone and dolostone & .00067 & to & 1.5 \\
Sandstone & .000067 & to & \\
& & & \\
& & & \\
\end{tabular}


Table 3. U.S. Environmental Protection Agency drinking-water regulations

[MCL, maximum contaminant level; SMCL, secondary maximum contaminant level; --, no established regulation; $\mathrm{mg} / \mathrm{L}$, milligrams per liter; $\mu \mathrm{g} / \mathrm{L}$, micrograms per liter; $\mathrm{pCi} / \mathrm{L}$, picocuries per liter; source, U.S. Environmental Protection Agency, 1988a, 1988b, 1988c, 1988d, 1989]

\begin{tabular}{|c|c|c|}
\hline $\begin{array}{l}\text { Property or } \\
\text { constituent }\end{array}$ & $\begin{array}{l}\text { Primary regulation } \\
\text { (MCL) }\end{array}$ & $\begin{array}{c}\text { Secondary regulation } \\
\text { (SMCL) }\end{array}$ \\
\hline $\begin{array}{l}\mathrm{pH} \\
\text { Sulfate } \\
\text { Chloride } \\
\text { Fluoride } \\
\text { Dissolved solids }\end{array}$ & $\begin{array}{l}-- \\
-- \\
-- \\
4.0 \mathrm{mg} / \mathrm{L} \\
--\end{array}$ & $\begin{array}{c}6.5-8.5 \mathrm{pH} \text { units } \\
250 \mathrm{mg} / \mathrm{L} \\
250 \mathrm{mg} / \mathrm{L} \\
2.0 \mathrm{mg} / \mathrm{L} \\
500 \mathrm{mg} / \mathrm{L}\end{array}$ \\
\hline Nitrate as nitrogen & $10 \mathrm{mg} / \mathrm{L}$ & -- \\
\hline $\begin{array}{l}\text { Arsenic } \\
\text { Barium } \\
\text { Cadmium } \\
\text { Chromium } \\
\text { Copper }\end{array}$ & $\begin{array}{c}50 \mu \mathrm{g} / \mathrm{L} \\
1,000 \mu \mathrm{g} / \mathrm{L} \\
10 \mu \mathrm{g} / \mathrm{L} \\
50 \mu \mathrm{g} / \mathrm{L} \\
--\end{array}$ & $\begin{array}{c}-- \\
-- \\
-- \\
-- \\
1,000 \mu \mathrm{g} / \mathrm{L}\end{array}$ \\
\hline $\begin{array}{l}\text { Iron } \\
\text { Lead } \\
\text { Manganese } \\
\text { Mercury } \\
\text { Selenium }\end{array}$ & $\begin{array}{c}-- \\
50 \mu \mathrm{g} / \mathrm{L} \\
. . \\
2 \mu \mathrm{g} / \mathrm{L} \\
10 \mu \mathrm{g} / \mathrm{L}\end{array}$ & $\begin{array}{l}300 \mu \mathrm{g} / \mathrm{L} \\
-- \\
50 \mu \mathrm{g} / \mathrm{L} \\
-- \\
--\end{array}$ \\
\hline $\begin{array}{l}\text { Silver } \\
\text { Zinc }\end{array}$ & $50 \mu \mathrm{g} / \mathrm{L}$ & $5,000 \mu \mathrm{g} / \mathrm{L}$ \\
\hline $\begin{array}{l}\text { Radium (radium-226 } \\
\text { and radium-228 combined) }\end{array}$ & $5 \mathrm{pCi} / \mathrm{L}$ & - \\
\hline $\begin{array}{l}\text { Gross-alpha activity } \\
\text { (including radium-226 but } \\
\text { not radon or uranium) }\end{array}$ & $15 \mathrm{pCi} / \mathrm{L}$ & -- \\
\hline $\begin{array}{l}\text { Gross-beta activity } \\
\text { as Cesium } 137\end{array}$ & $200 \mathrm{pCi} / \mathrm{L}$ & - \\
\hline $\begin{array}{l}\text { Endrin } \\
\text { Lindane } \\
\text { Methoxychlor } \\
\text { Toxaphene } \\
\text { 2,4-D }\end{array}$ & $\begin{aligned} .2 \mu \mathrm{g} / \mathrm{L} \\
4 \mu \mathrm{g} / \mathrm{L} \\
100 \mu \mathrm{g} / \mathrm{L} \\
5 \mu \mathrm{g} / \mathrm{L} \\
100 \mu \mathrm{g} / \mathrm{L}\end{aligned}$ & $\begin{array}{l}- \\
-- \\
-- \\
-- \\
--\end{array}$ \\
\hline $\begin{array}{l}\text { 2,4,5-TP (Silvex) } \\
\text { Benzene } \\
\text { Carbon tetrachloride } \\
\text { 1,2-dichloroethane } \\
\text { 1,1-dichloroethylene } \\
\text { Paradichlorobenzene }\end{array}$ & $\begin{aligned} 10 & \mu \mathrm{g} / \mathrm{L} \\
5 & \mu \mathrm{g} / \mathrm{L} \\
5 & \mu \mathrm{g} / \mathrm{L} \\
5 & \mu \mathrm{g} / \mathrm{L} \\
7 & \mu \mathrm{g} / \mathrm{L} \\
75 & \mu \mathrm{g} / \mathrm{L}\end{aligned}$ & $\begin{array}{l}-- \\
-- \\
- \\
- \\
-- \\
--\end{array}$ \\
\hline $\begin{array}{l}\text { 1,1,1-trichloroethane } \\
\text { Trichloroethylene } \\
\text { Vinyl chloride }\end{array}$ & $\begin{array}{r}200 \mu \mathrm{g} / \mathrm{L} \\
5 \mu \mathrm{g} / \mathrm{L} \\
2 \mu \mathrm{g} / \mathrm{L}\end{array}$ & $\begin{array}{l}-- \\
-- \\
-\end{array}$ \\
\hline
\end{tabular}


Table 4. Health advisory and risk-assessment concentrations for selected pesticides in drinking water

$[\mu \mathrm{g} / \mathrm{L}$, micrograms per liter; --, no data; source, U.S. Environmental

Protection Agency, 1987, 1989]

\begin{tabular}{lcc}
\hline & $\begin{array}{c}\text { Health advisory } \\
(\mu \mathrm{g} / \mathrm{L})\end{array}$ & $\begin{array}{c}\text { Risk-assessment } \\
\text { concentration }(\mu \mathrm{g} / \mathrm{L})\end{array}$ \\
\hline Alachlor & & \\
Atrazine & 0 & $0.15-1.5$ \\
Cyanazine & 3.0 & -- \\
Metolachlor & 9.0 & - \\
Simazine & 10 & - \\
\hline
\end{tabular}


Table 5. Summary of nitrate analyses of samples from private wells, 1981-86

[Data from University of Iowa Hygienic Laboratory, written commun., 1988]

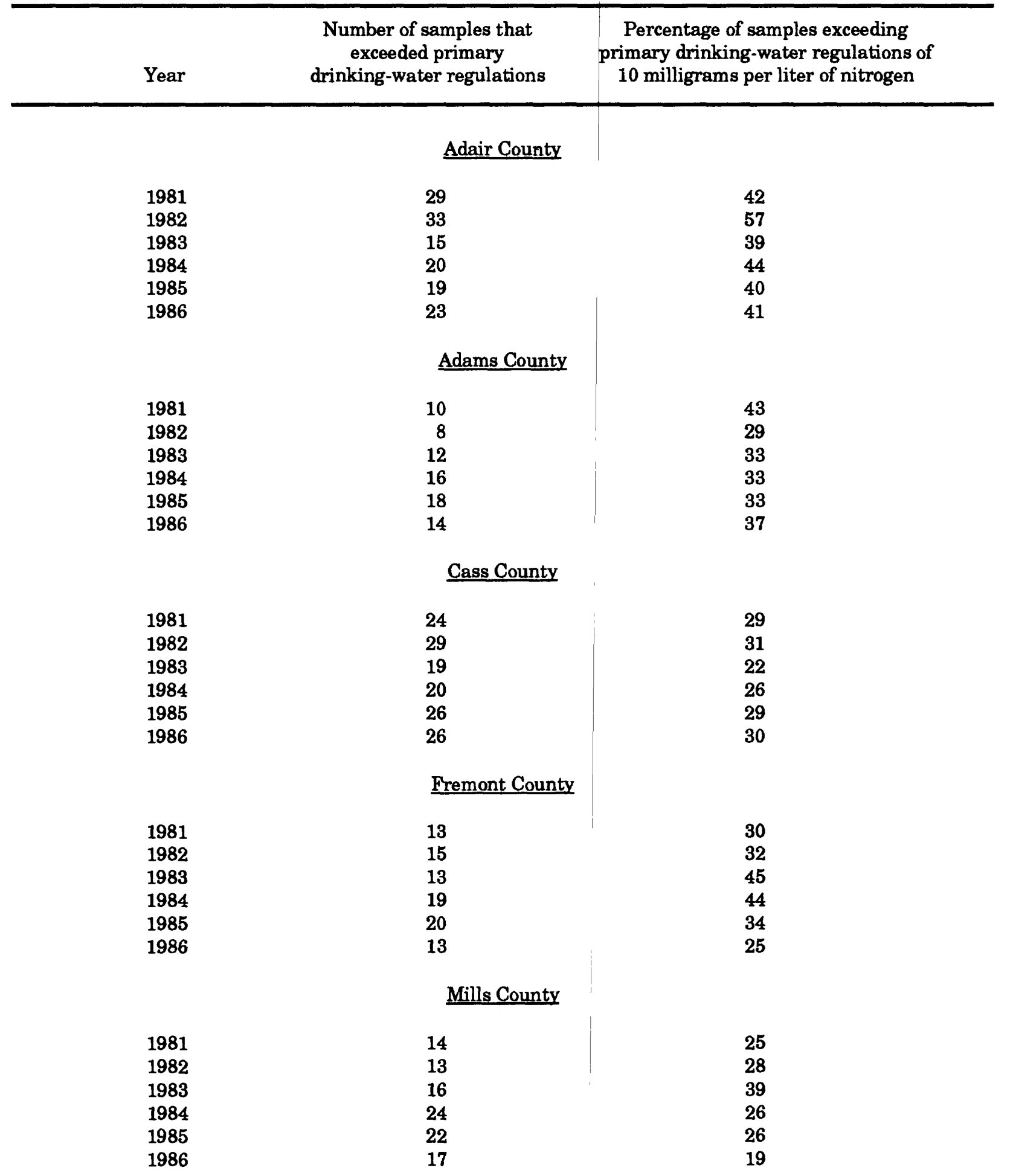


Table 5. Summary of nitrate analyses of samples from private wells, 1981-86--Continued

\begin{tabular}{|c|c|c|}
\hline Year & $\begin{array}{l}\text { Number of samples that } \\
\text { exceeded primary } \\
\text { drinking-water regulation }\end{array}$ & $\begin{array}{l}\text { Percentage of samples exceeding } \\
\text { primary drinking-water regulation of } \\
10 \text { milligrams per liter of nitrogen }\end{array}$ \\
\hline \multicolumn{3}{|c|}{ Montgomery County } \\
\hline 1981 & 9 & 20 \\
\hline 1982 & 16 & 33 \\
\hline 1983 & 20 & 39 \\
\hline 1984 & 36 & 53 \\
\hline 1985 & 23 & 42 \\
\hline 1986 & 16 & 26 \\
\hline \multicolumn{3}{|c|}{ Page County } \\
\hline 1981 & 11 & 48 \\
\hline 1982 & 21 & 57 \\
\hline 1983 & 18 & 44 \\
\hline 1984 & 15 & 42 \\
\hline 1985 & 14 & 35 \\
\hline 1986 & 25 & 39 \\
\hline \multicolumn{3}{|c|}{ Pottawattamie County } \\
\hline 1981 & 25 & 21 \\
\hline 1982 & 22 & 19 \\
\hline 1983 & 36 & 28 \\
\hline 1984 & 55 & 33 \\
\hline 1985 & 39 & 23 \\
\hline 1986 & 39 & 20 \\
\hline \multicolumn{3}{|c|}{ Taylor County } \\
\hline 1981 & 12 & 35 \\
\hline 1982 & 7 & 26 \\
\hline 1983 & 20 & 45 \\
\hline 1984 & 19 & 39 \\
\hline 1985 & 16 & 39 \\
\hline 1986 & 11 & 26 \\
\hline \multicolumn{3}{|c|}{ Statewide } \\
\hline 1981 & 1,382 & 18 \\
\hline 1982 & 1,449 & 21 \\
\hline 1983 & 1,763 & 23 \\
\hline 1984 & 1,568 & 21 \\
\hline 1985 & 1,393 & 19 \\
\hline 1986 & 1,632 & 18 \\
\hline
\end{tabular}


Table 6. Stratigraphic units in the study area

[The stratigraphic nomenclature used herein is that of the Iowa Department of Natural Resources, Geological Survey Bureau]

\begin{tabular}{|c|c|c|c|c|c|}
\hline Era & Period & Epoch & Formation & Member & Lithology \\
\hline \multirow[t]{2}{*}{ Cenozoic } & Quaternary & $\begin{array}{l}\text { Holocene } \\
\text { Pleistocene }\end{array}$ & & & $\begin{array}{l}\text { Alluvium, } \\
\text { loess, and } \\
\text { glacial drift }\end{array}$ \\
\hline & Tertiary & Pliocene & & & \\
\hline \multirow[t]{2}{*}{ Mesozoic } & Cretaceous & & Dakota & Woodbury & $\begin{array}{l}\text { Shale, } \\
\text { sandstone }\end{array}$ \\
\hline & & & & Nishnabotna & $\begin{array}{l}\text { Sandstone, } \\
\text { shale }\end{array}$ \\
\hline \multirow[t]{6}{*}{ Paleozoic } & Pennsylvanian & (Late) & $\begin{array}{l}\text { Und } \\
\text { (for }\end{array}$ & $\begin{array}{l}\text { iated } \\
\text { port) }\end{array}$ & $\begin{array}{l}\text { Limestone, } \\
\text { shale }\end{array}$ \\
\hline & Mississippian & & $\begin{array}{l}\text { Und } \\
\text { (for }\end{array}$ & $\begin{array}{l}\text { iated } \\
\text { sort) }\end{array}$ & $\begin{array}{l}\text { Limestone, } \\
\text { dolomite, } \\
\text { shale }\end{array}$ \\
\hline & Devonian & & $\begin{array}{l}\text { Und } \\
\text { (for }\end{array}$ & $\begin{array}{l}\text { iated } \\
\text { sort) }\end{array}$ & $\begin{array}{l}\text { Limestone, } \\
\text { dolomite, } \\
\text { shale }\end{array}$ \\
\hline & Silurian & & $\begin{array}{l}\text { Und } \\
\text { (for }\end{array}$ & $\begin{array}{l}\text { iated } \\
\text { oort) }\end{array}$ & Dolomite \\
\hline & Ordovician & & $\begin{array}{l}\text { Unc } \\
\text { (for }\end{array}$ & $\begin{array}{l}\text { iated } \\
\text { port) }\end{array}$ & $\begin{array}{l}\text { Dolomite, } \\
\text { shale, } \\
\text { limestone, } \\
\text { sandstone }\end{array}$ \\
\hline & Cambrian & & $\begin{array}{l}\text { Unc } \\
\text { (for }\end{array}$ & $\begin{array}{l}\text { iated } \\
\text { port) }\end{array}$ & $\begin{array}{l}\text { Sandstone, } \\
\text { shale, } \\
\text { dolomite }\end{array}$ \\
\hline
\end{tabular}




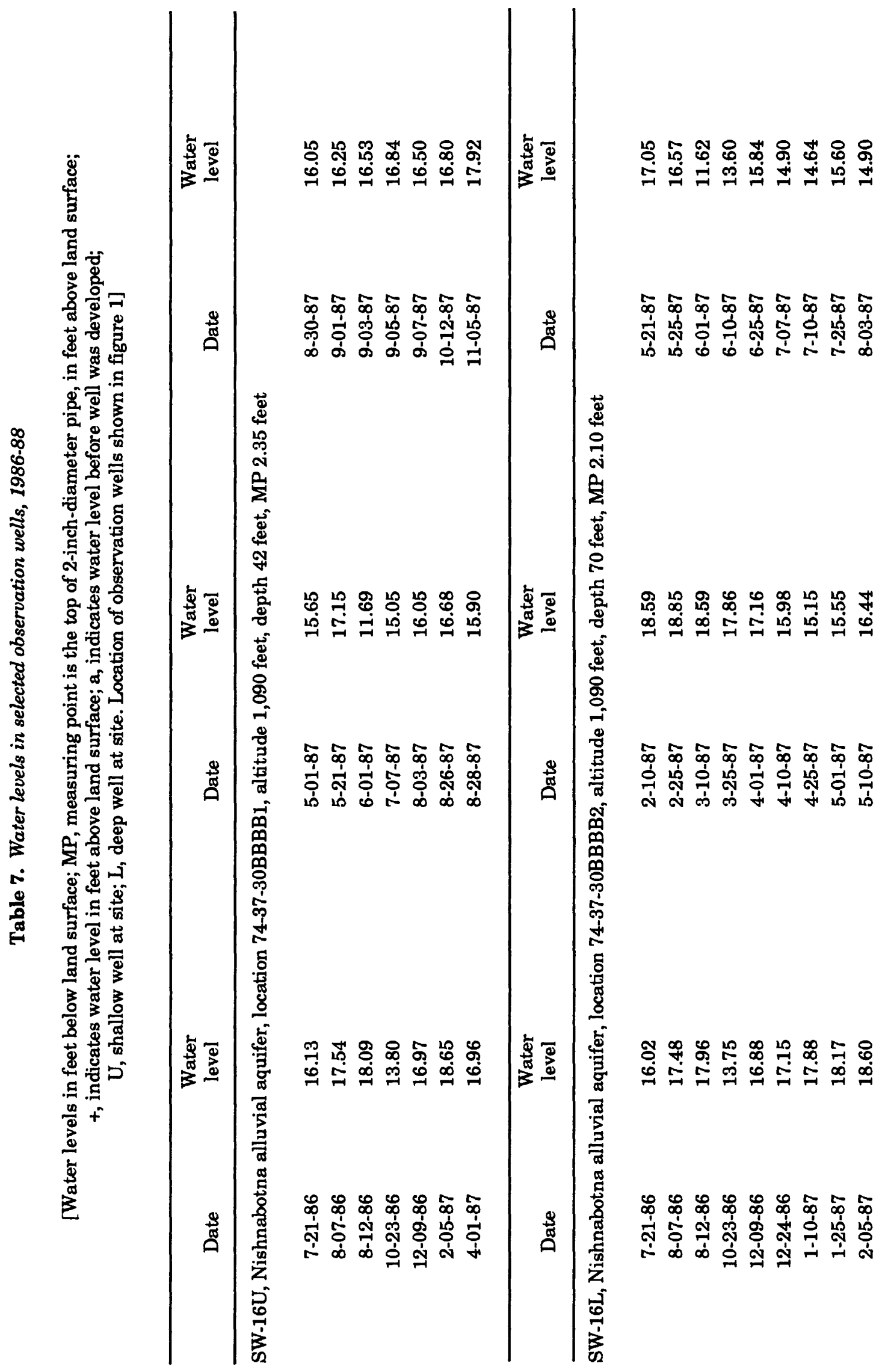




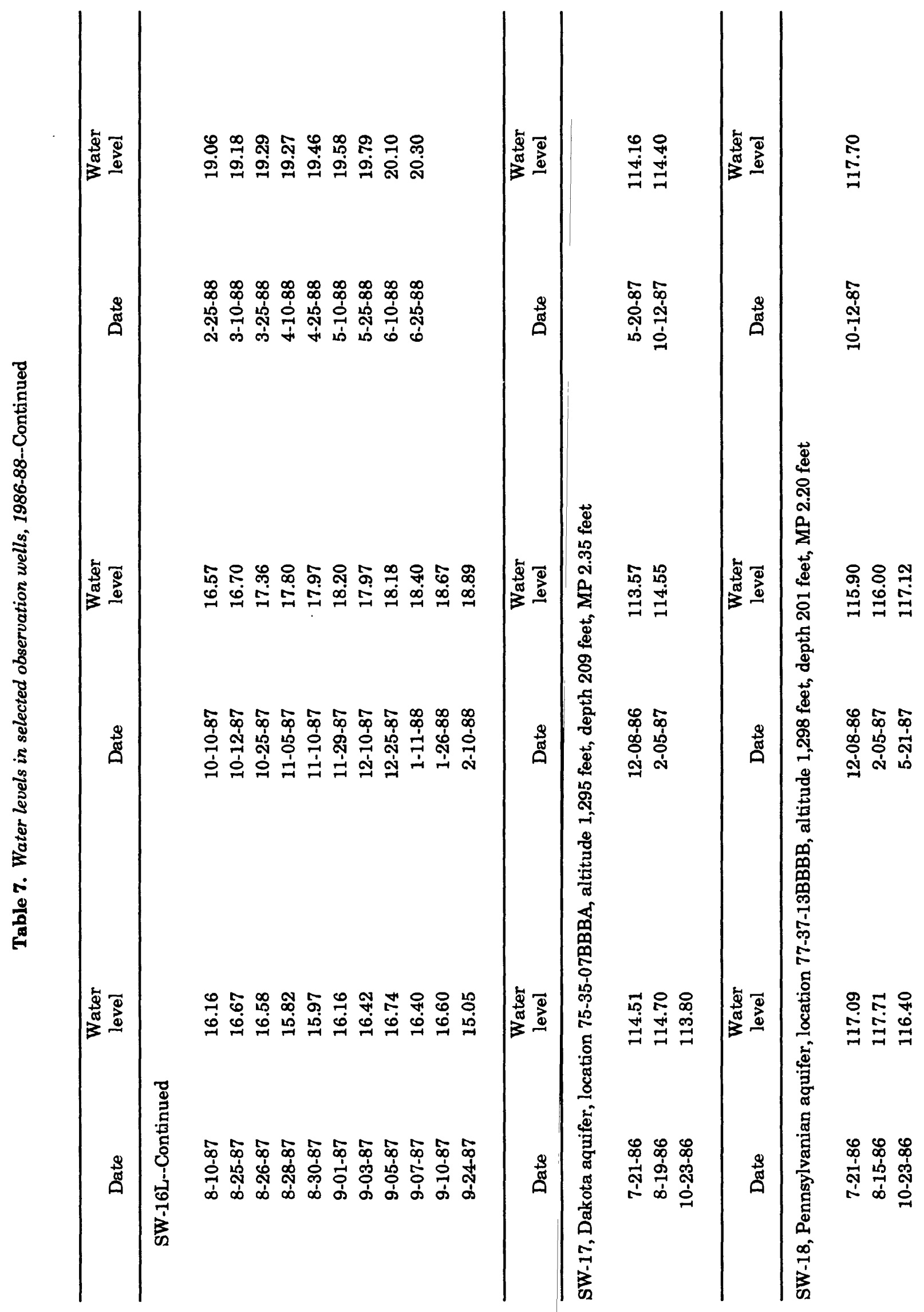




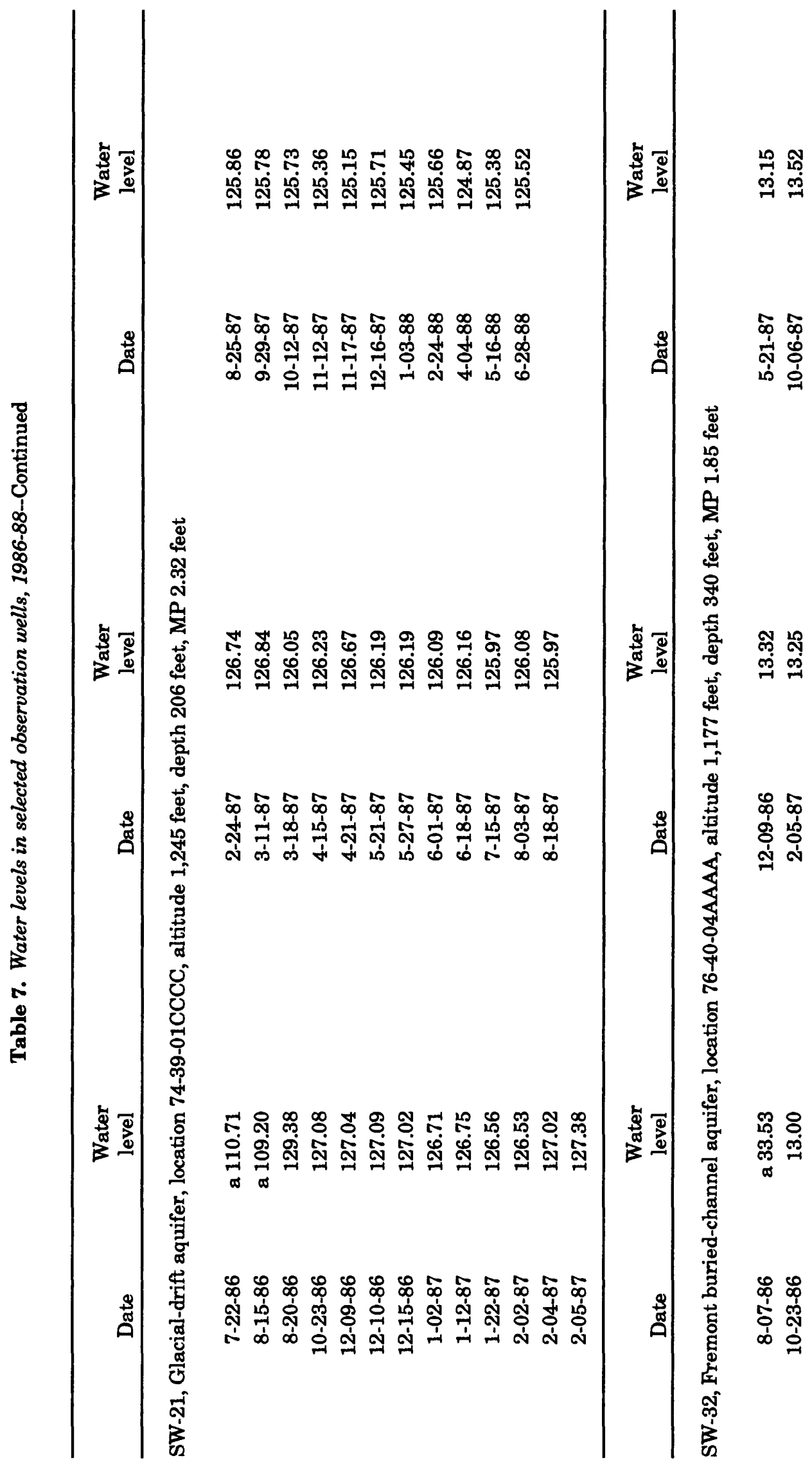




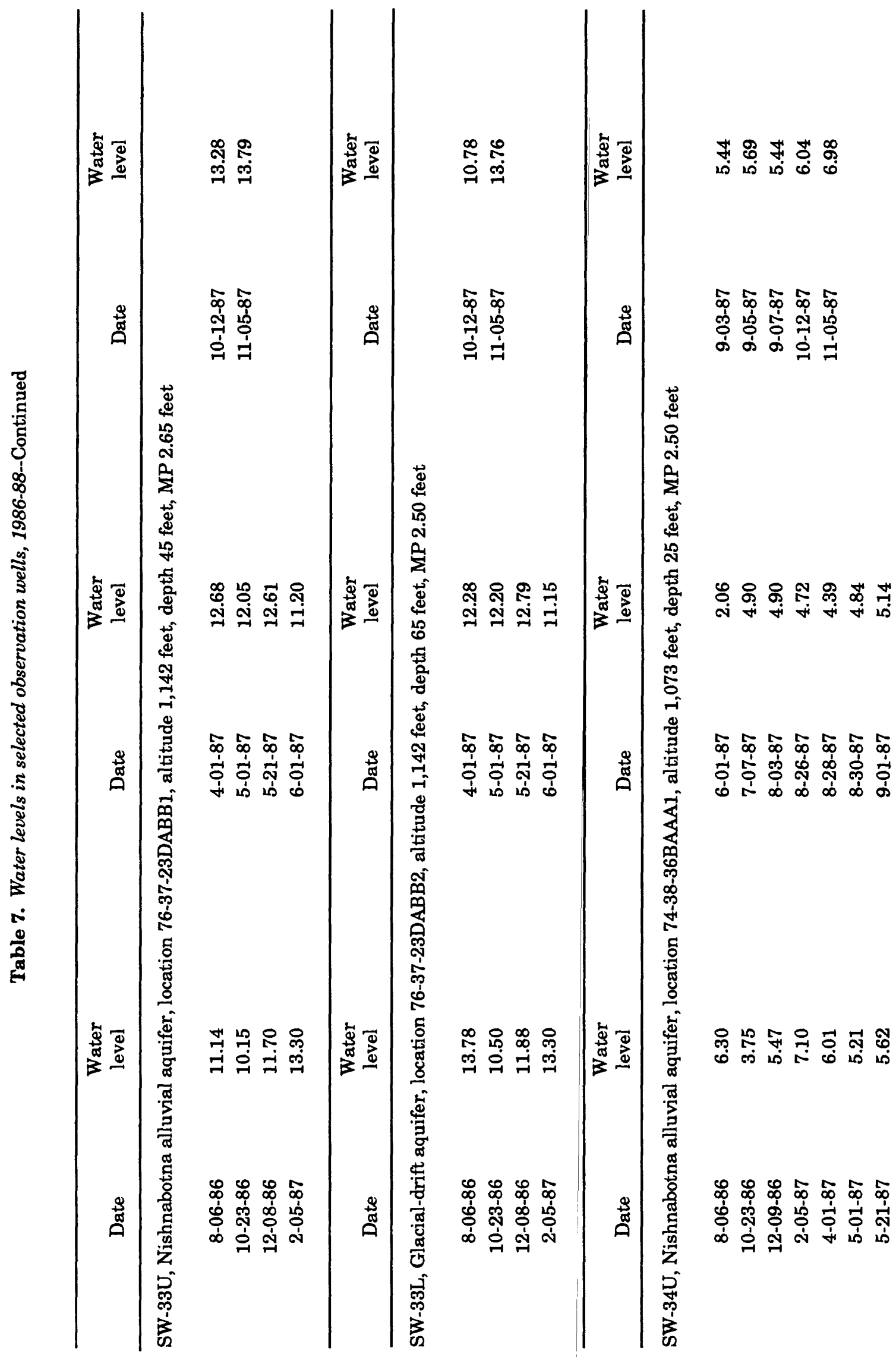




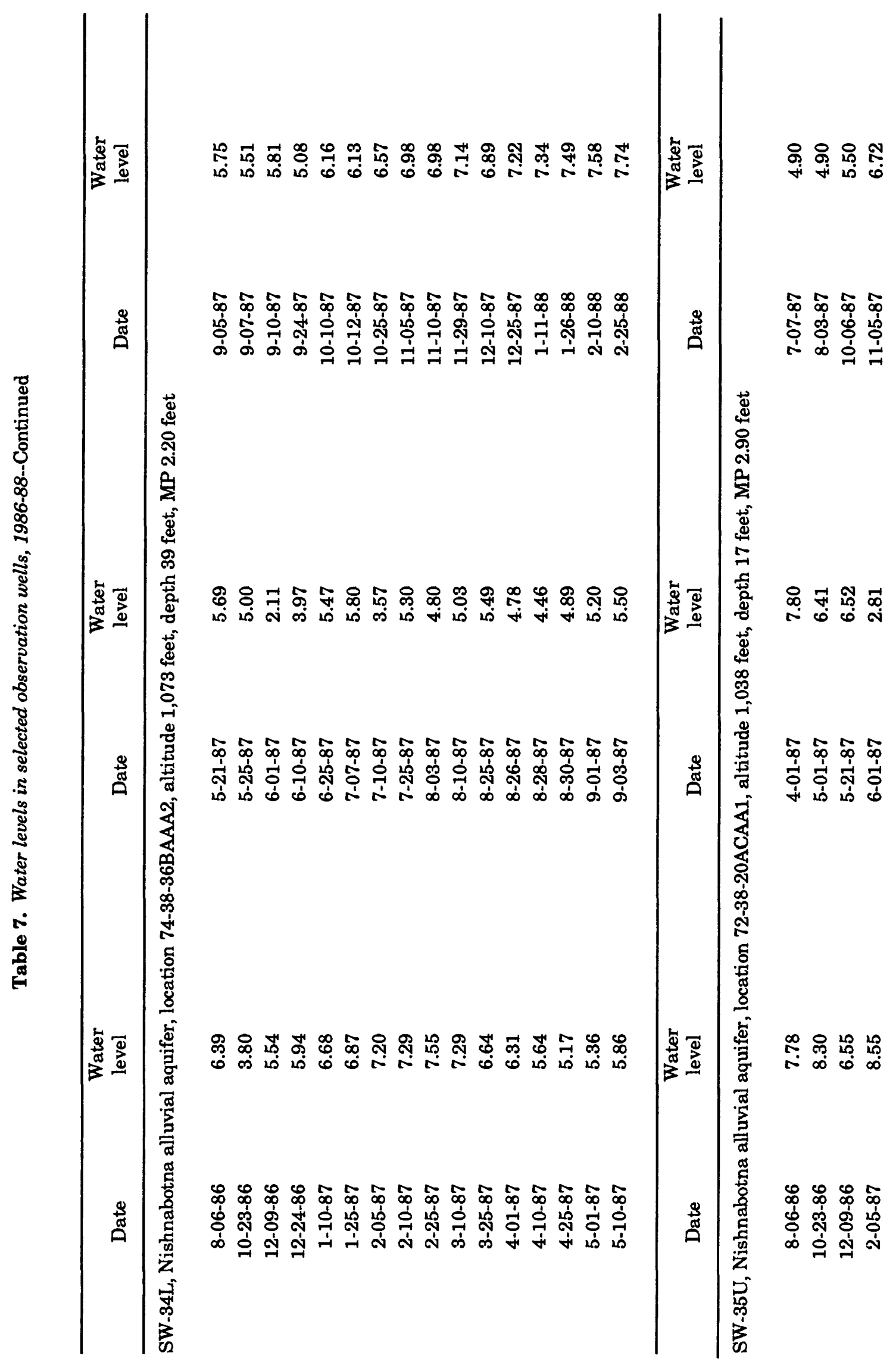




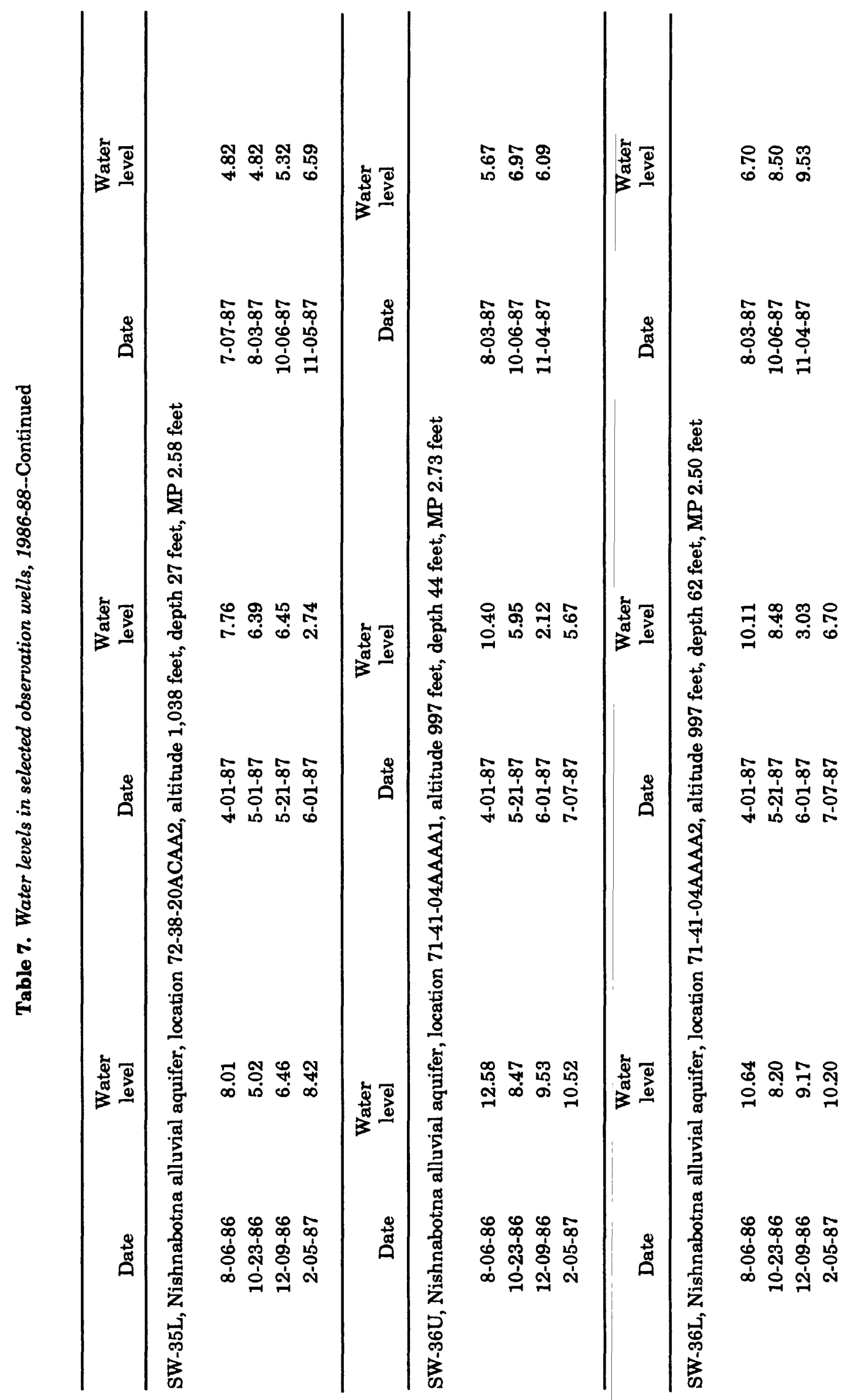




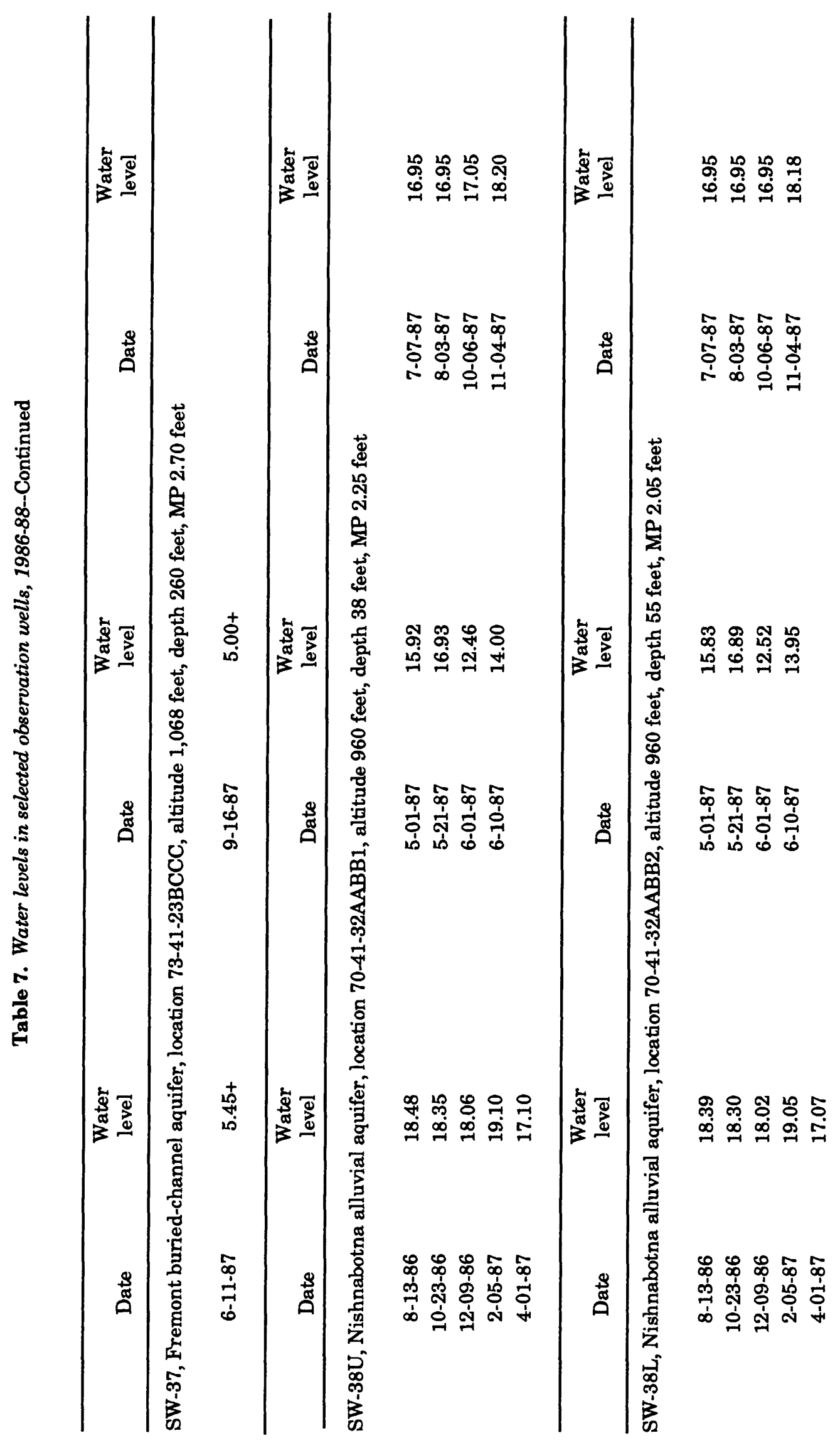




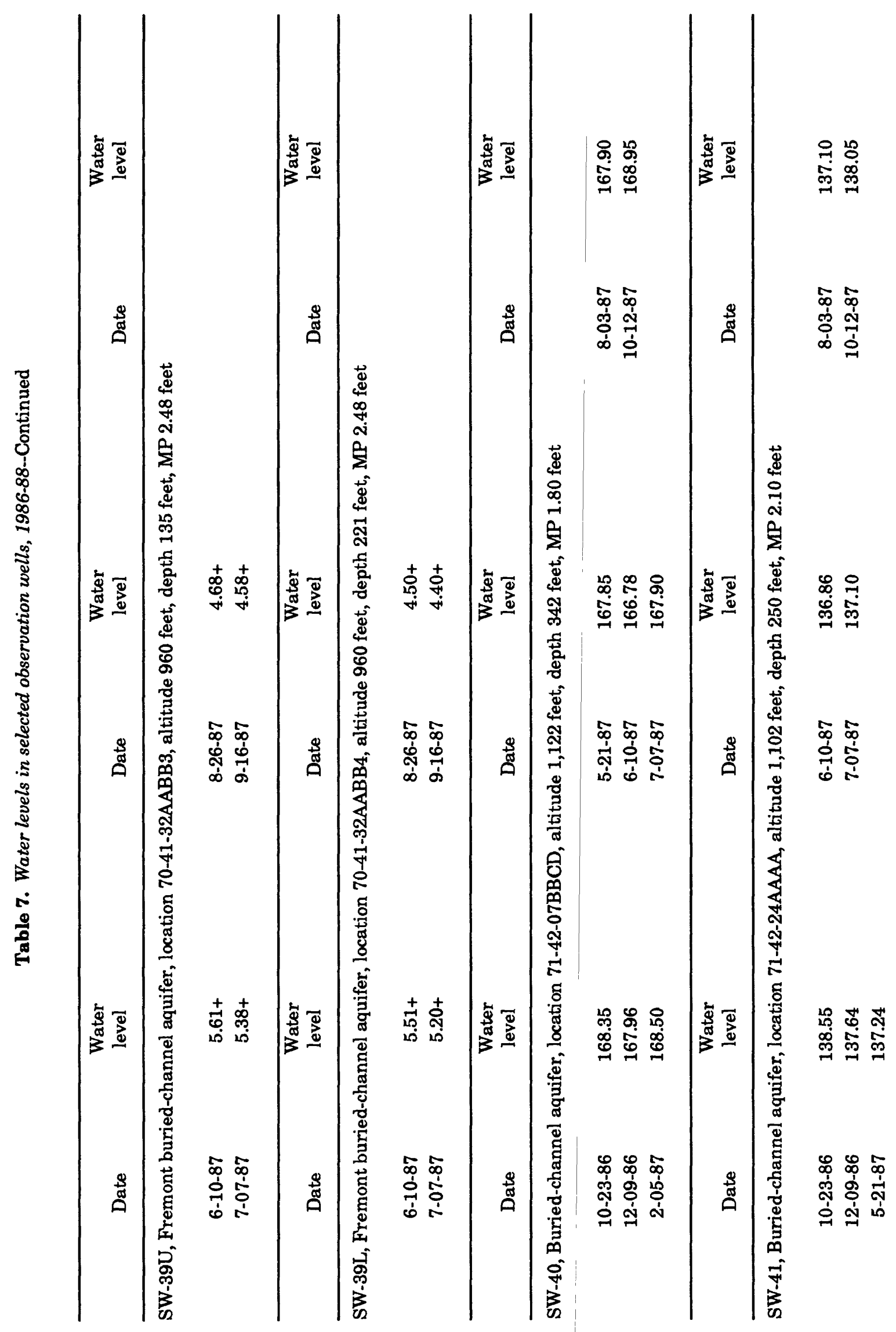




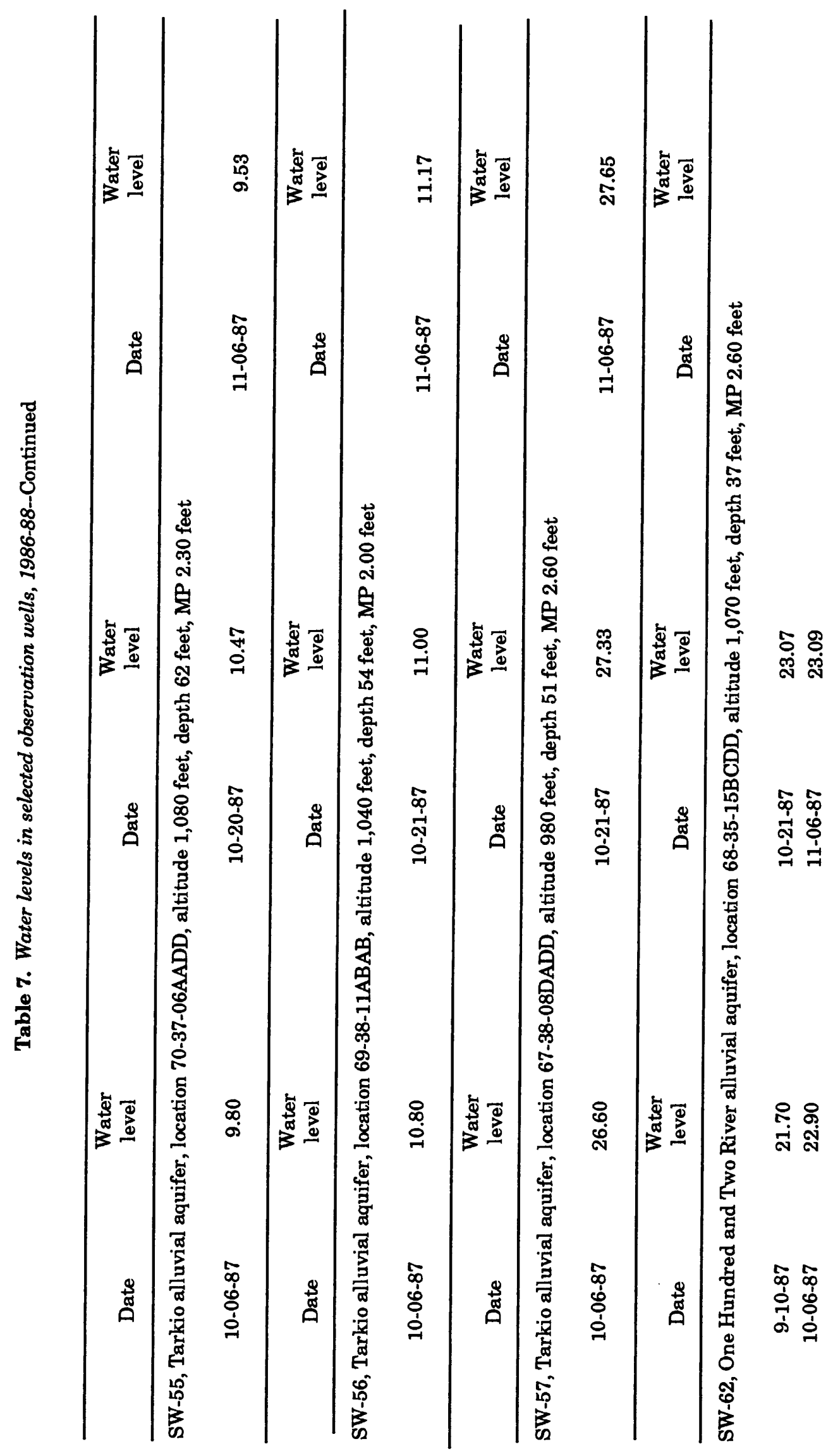




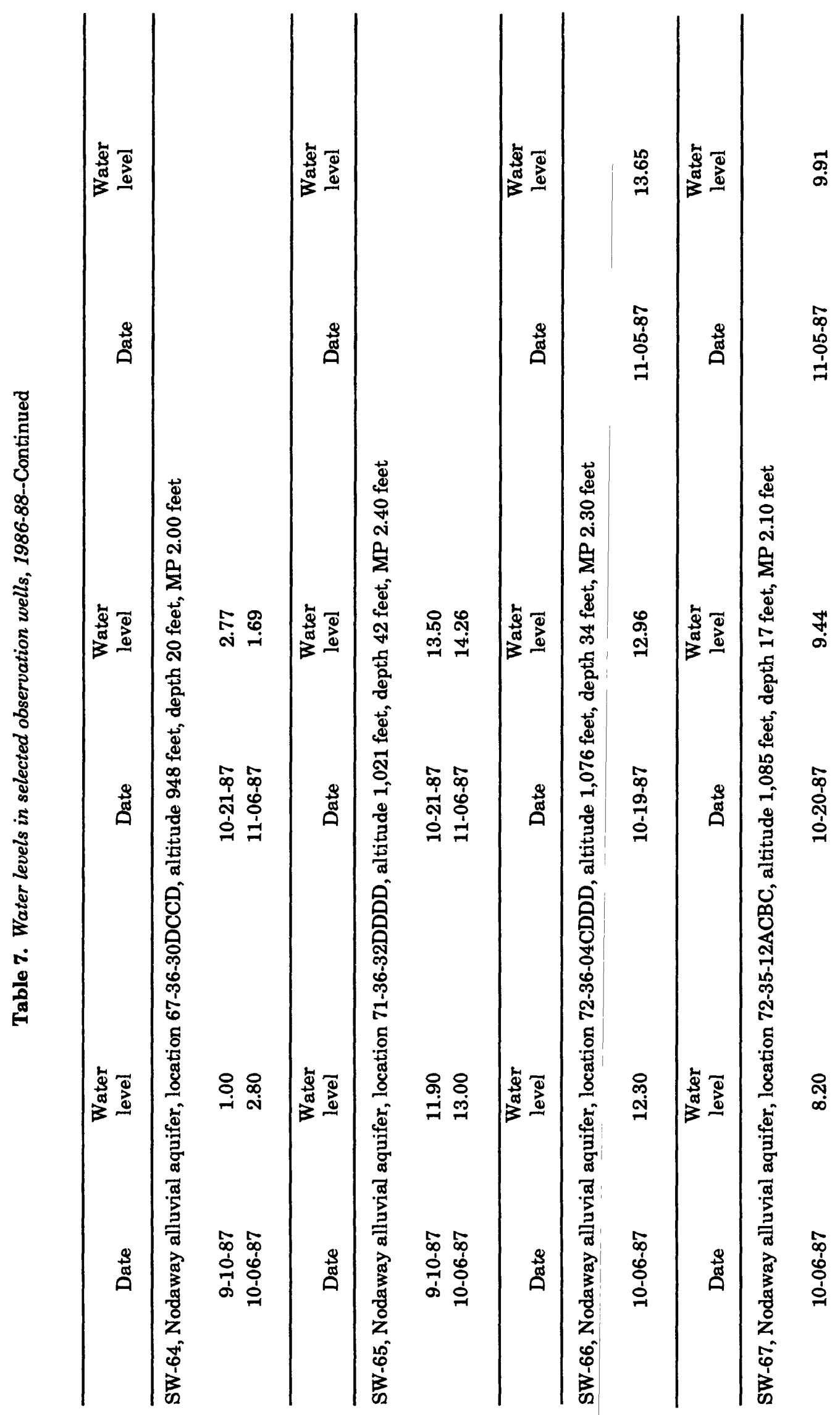

132 GROUND-WATER RESOURCES IN SOUTHWEST IOWA 


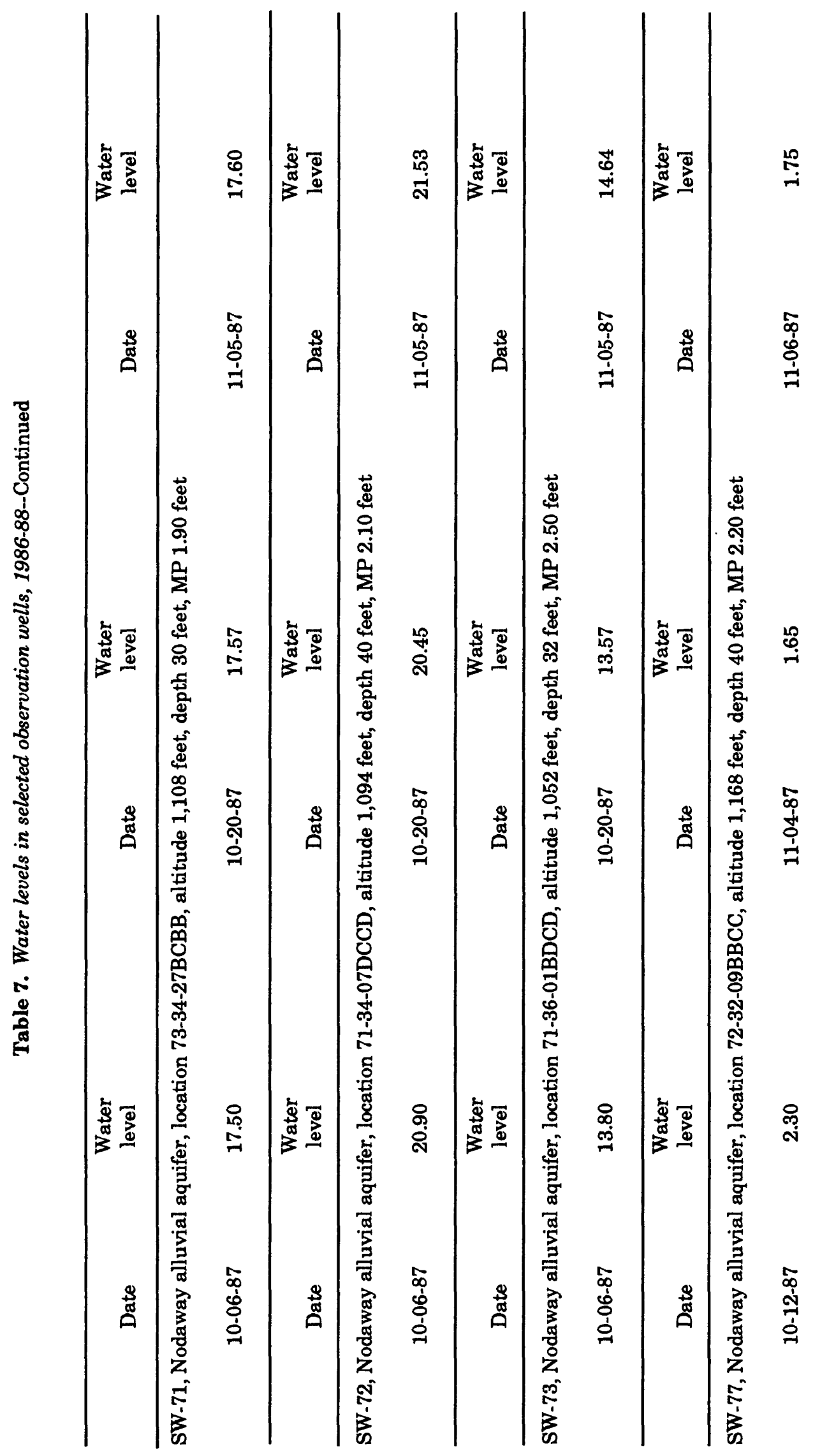




$$
\text { 㖪 }
$$




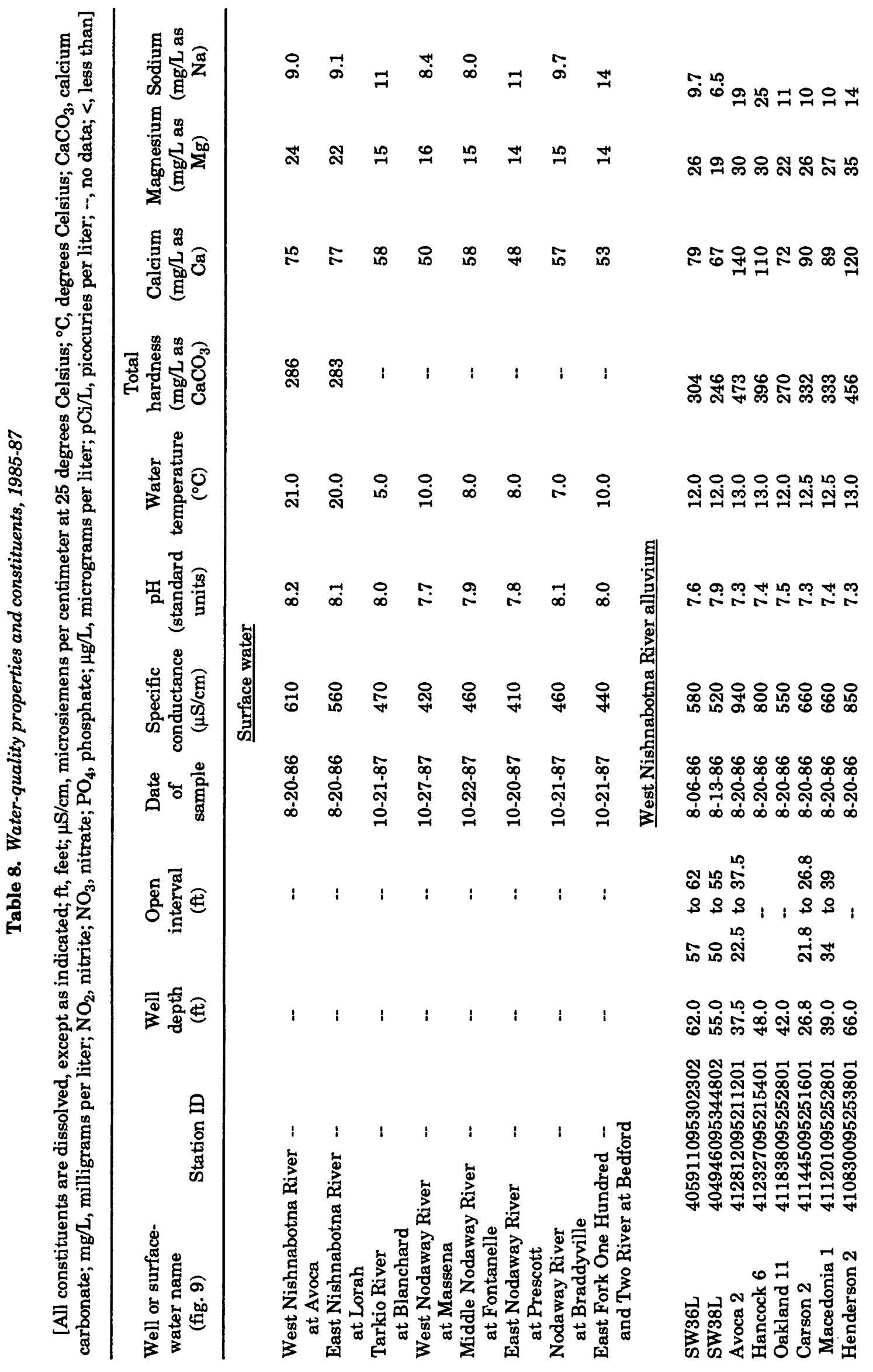




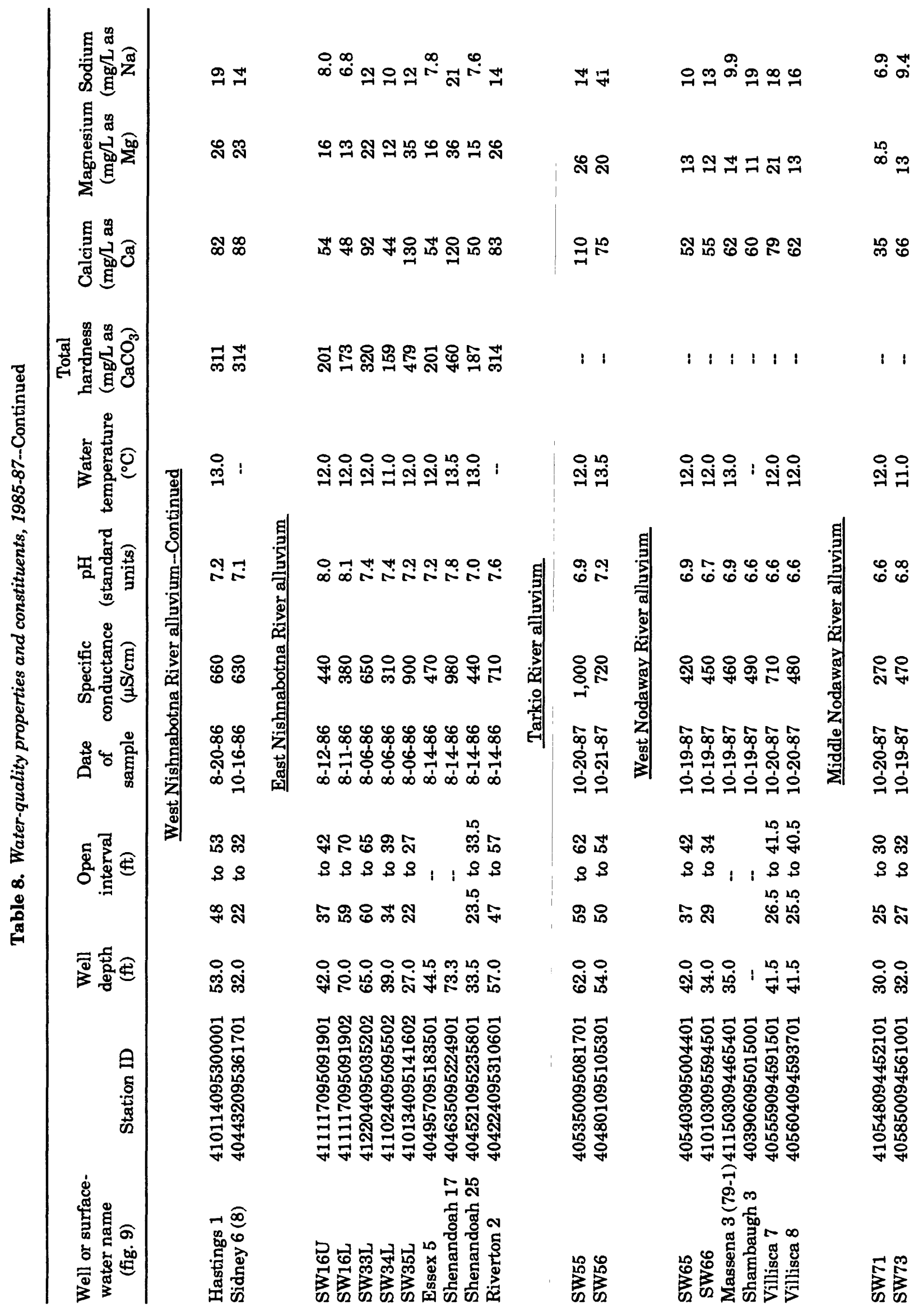




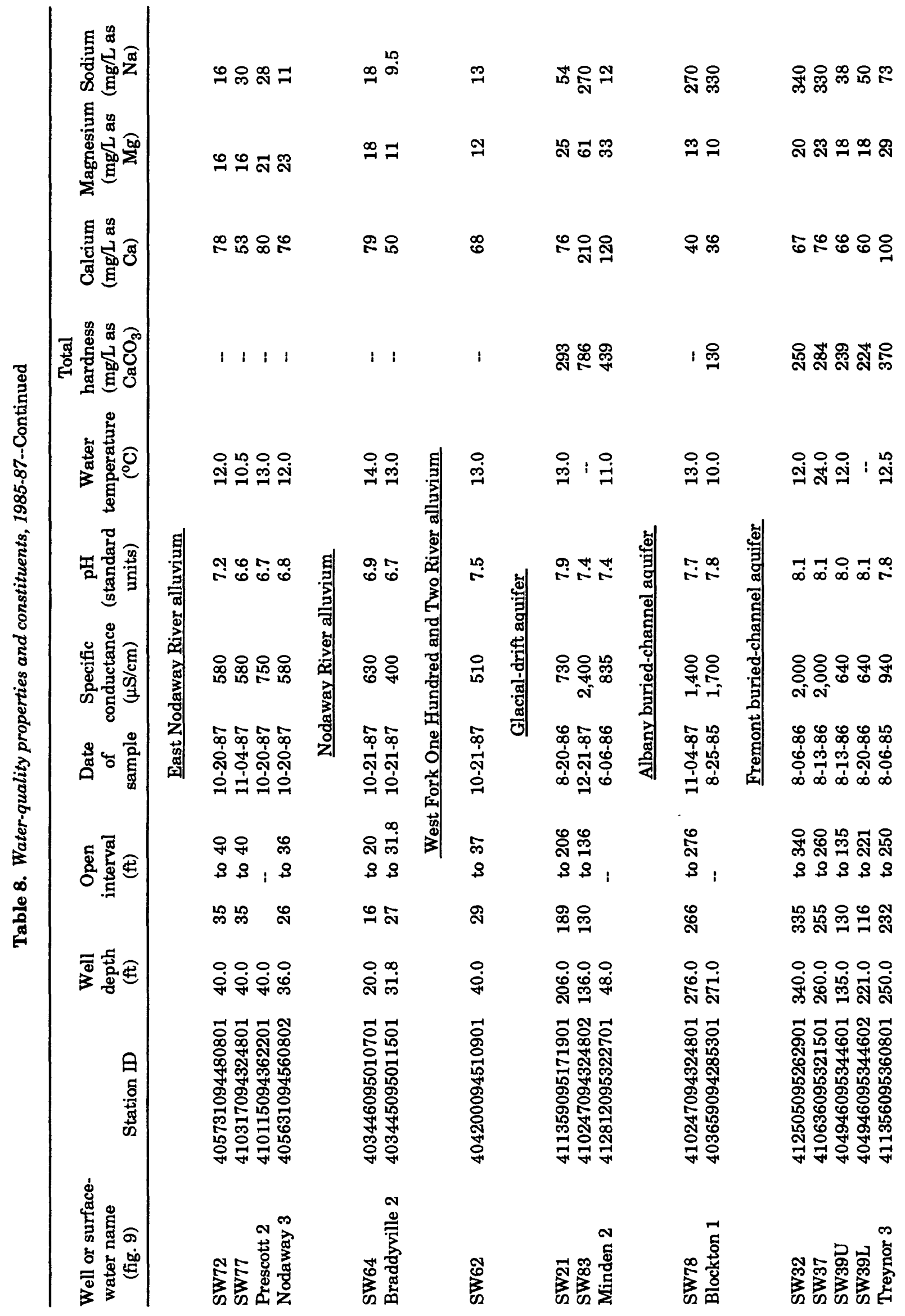




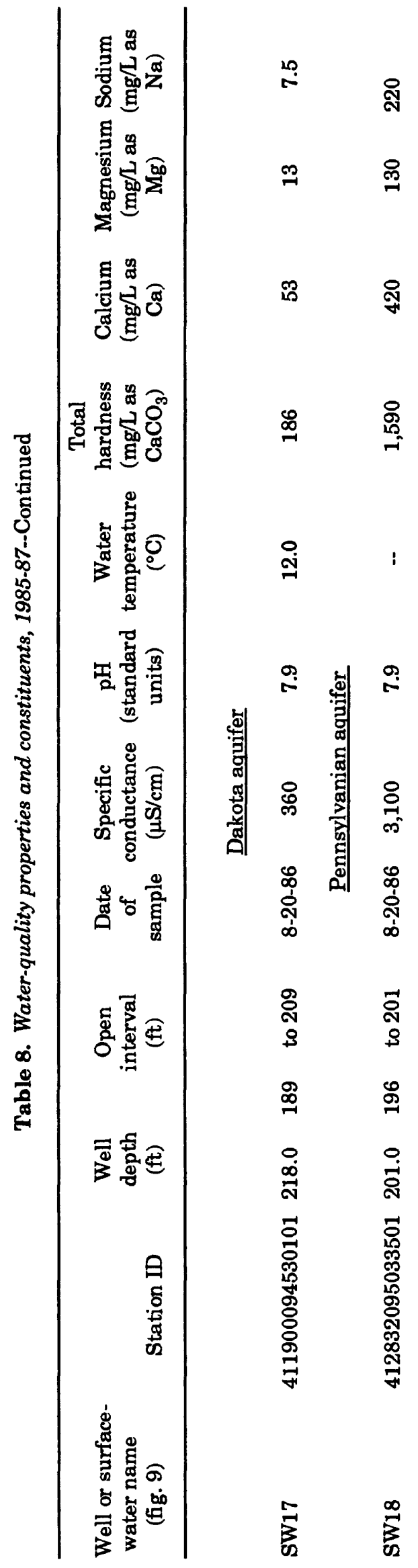

138 GROUND-WATER RESOURCES IN SOUTHWEST IOWA 


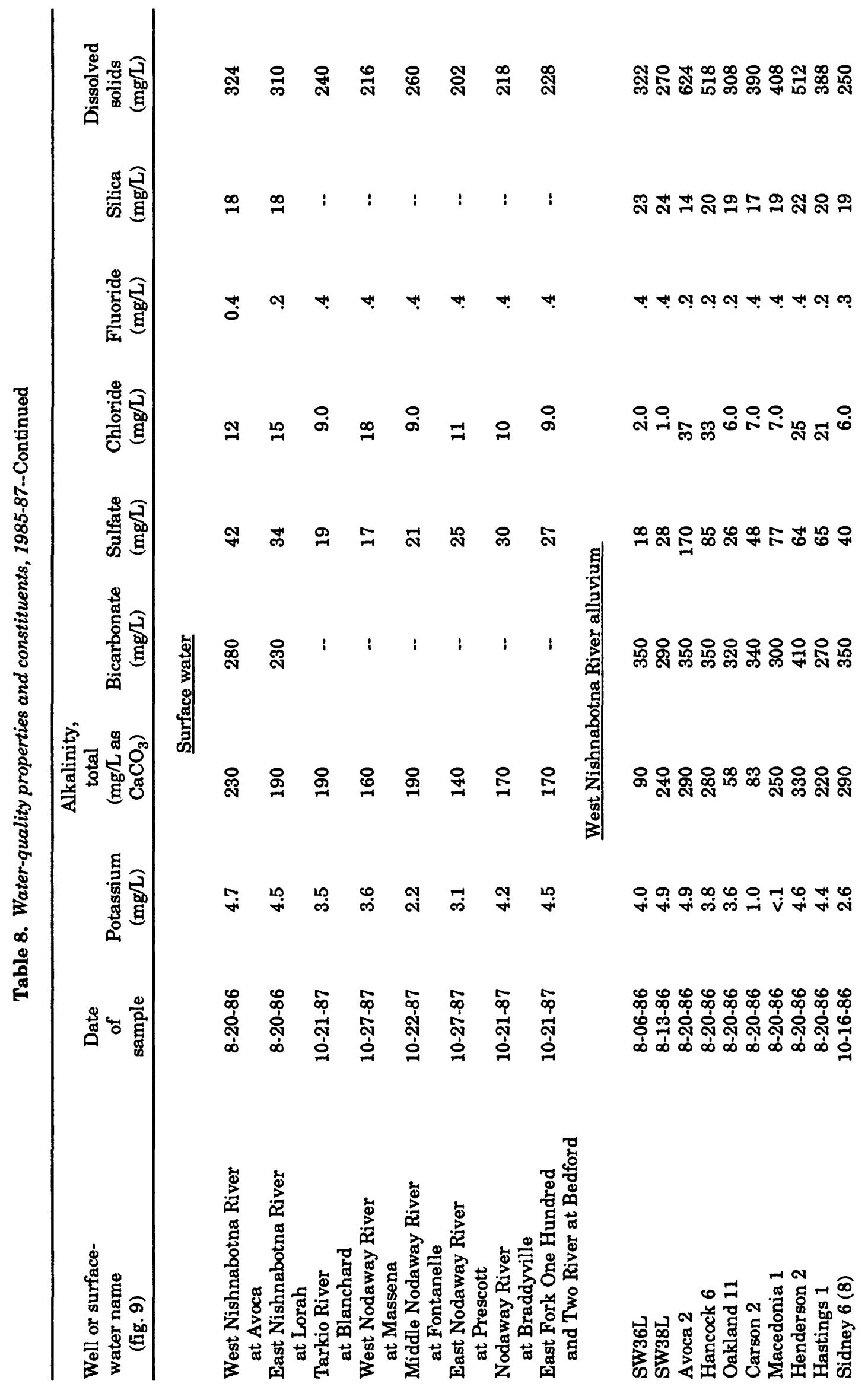




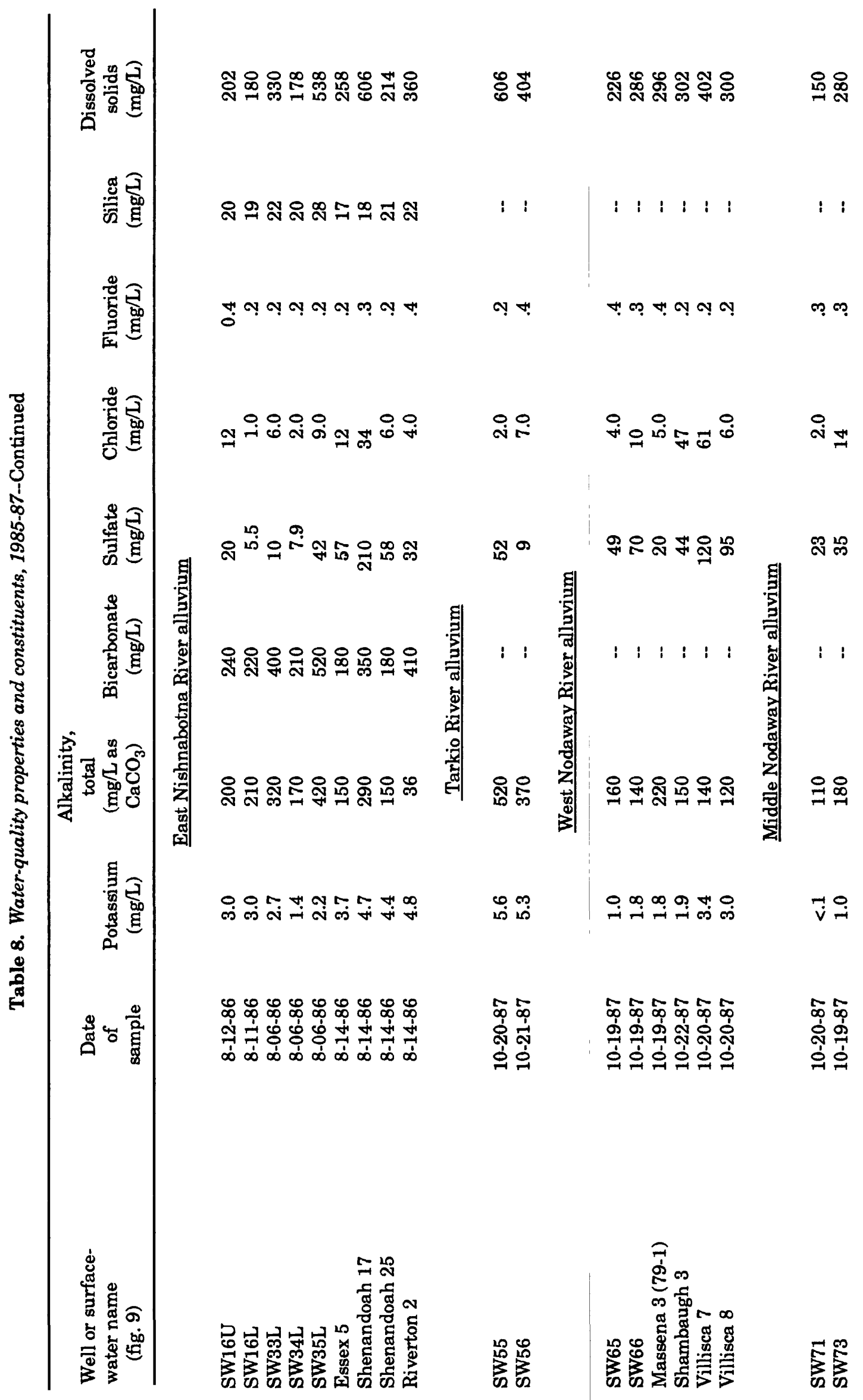




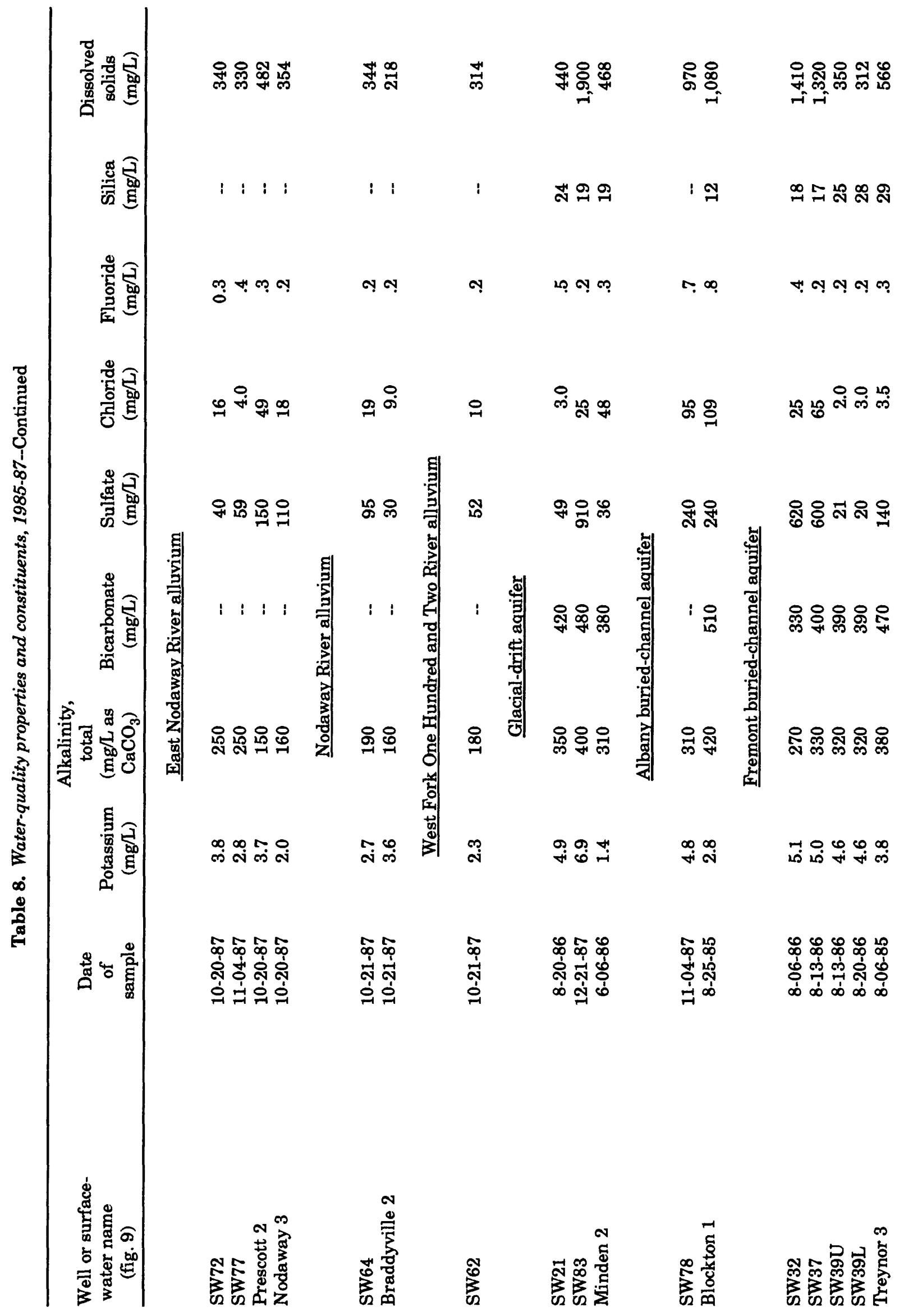




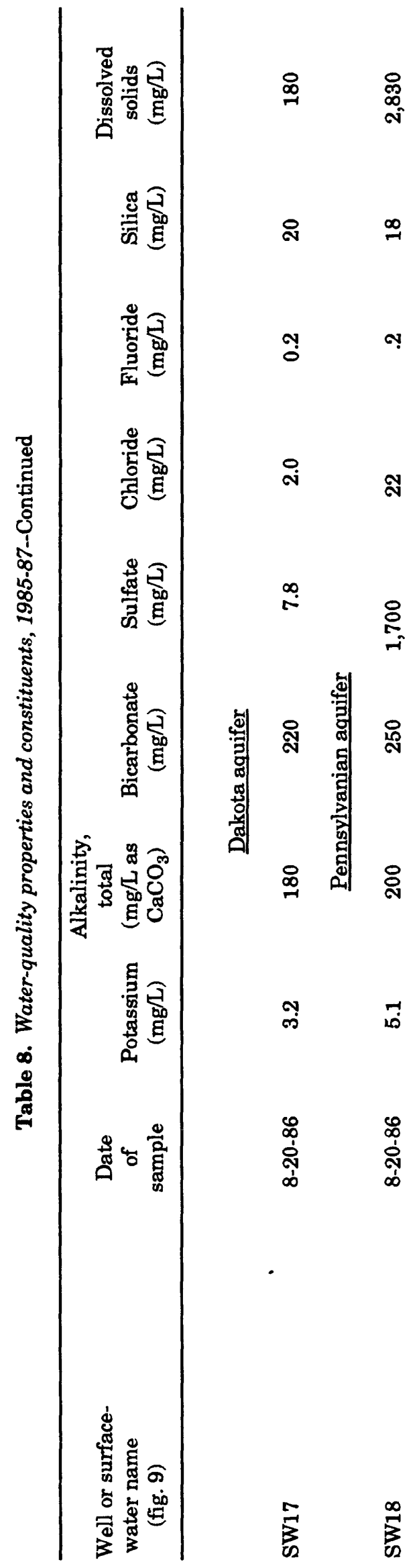




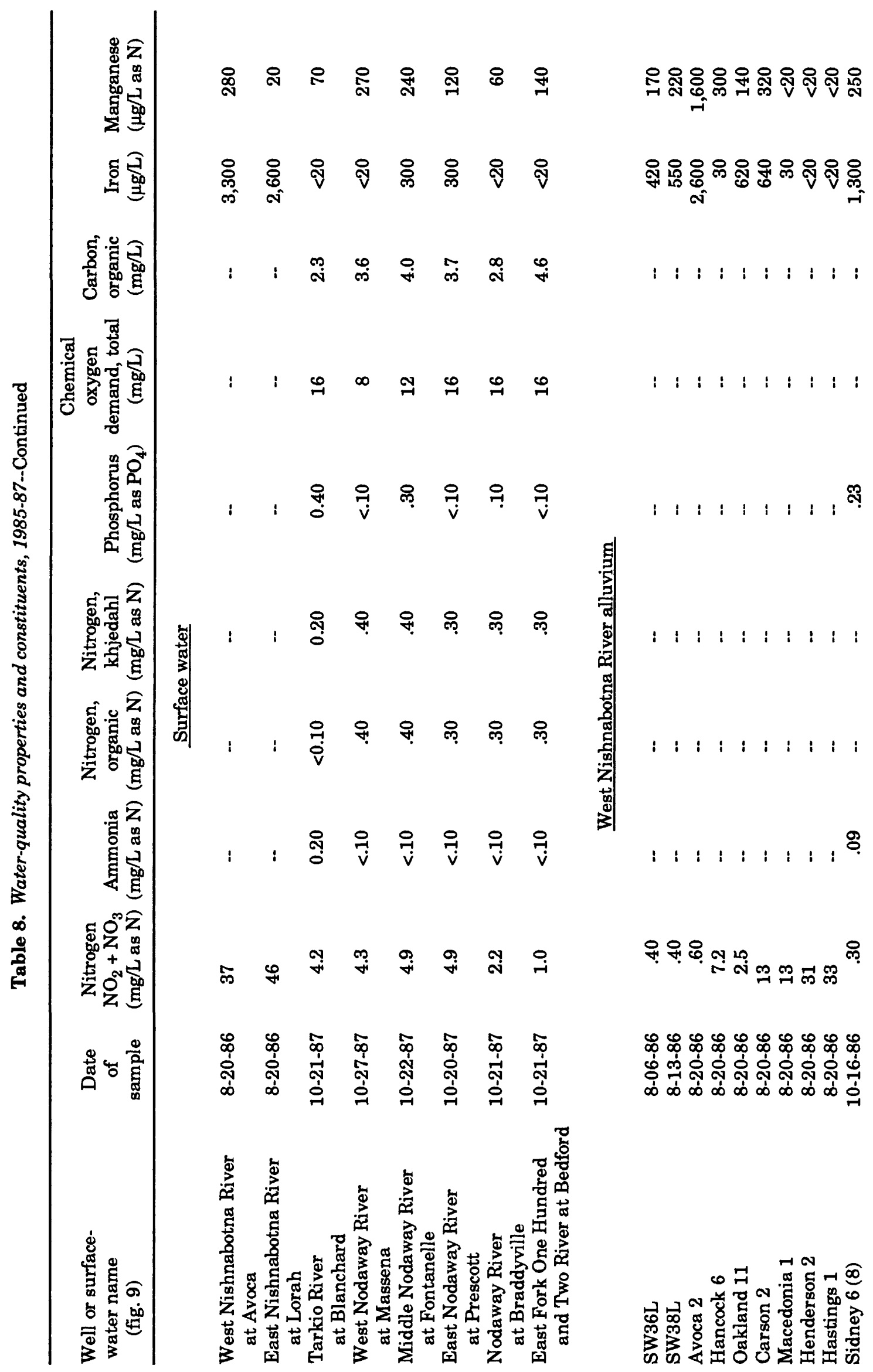




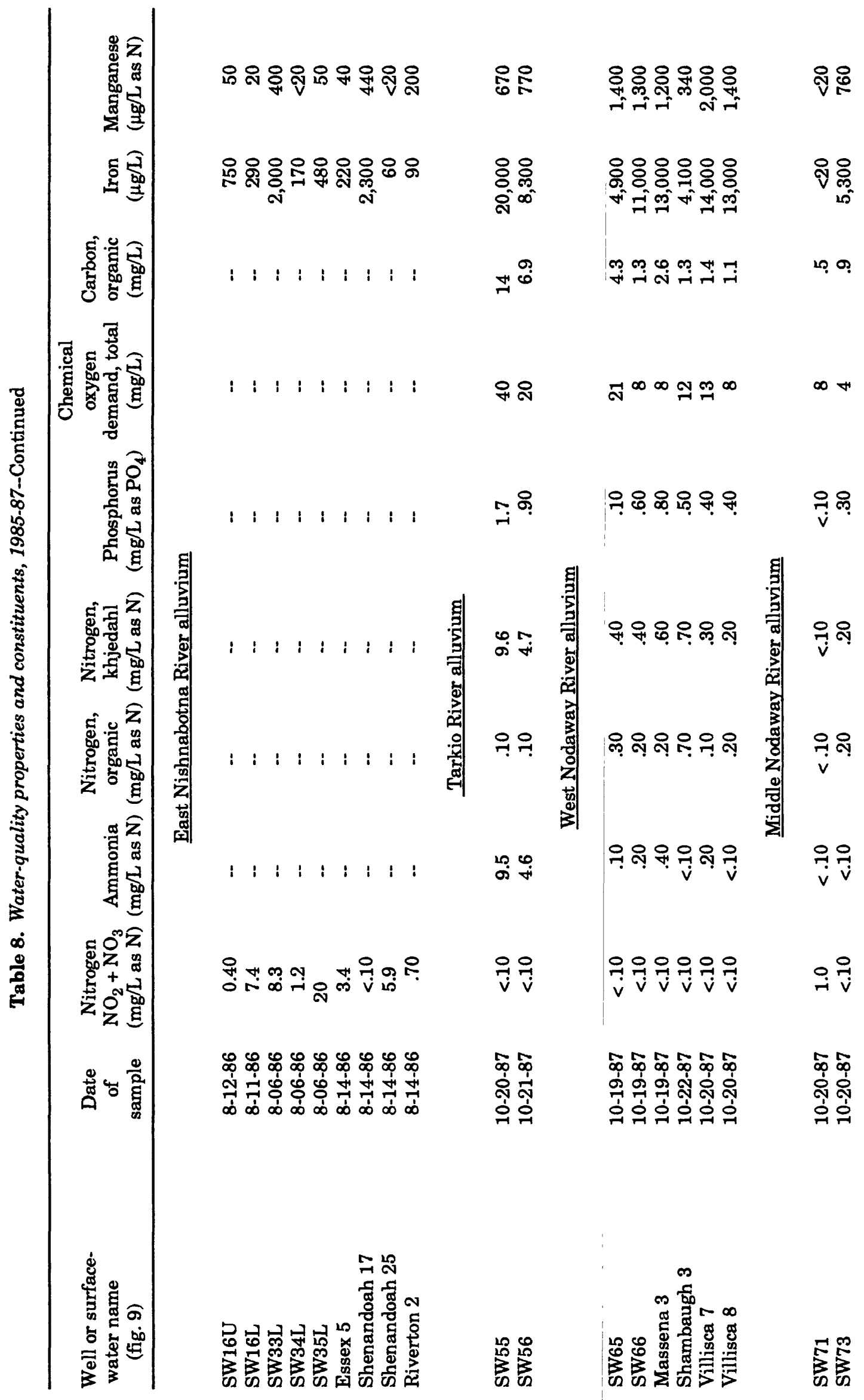




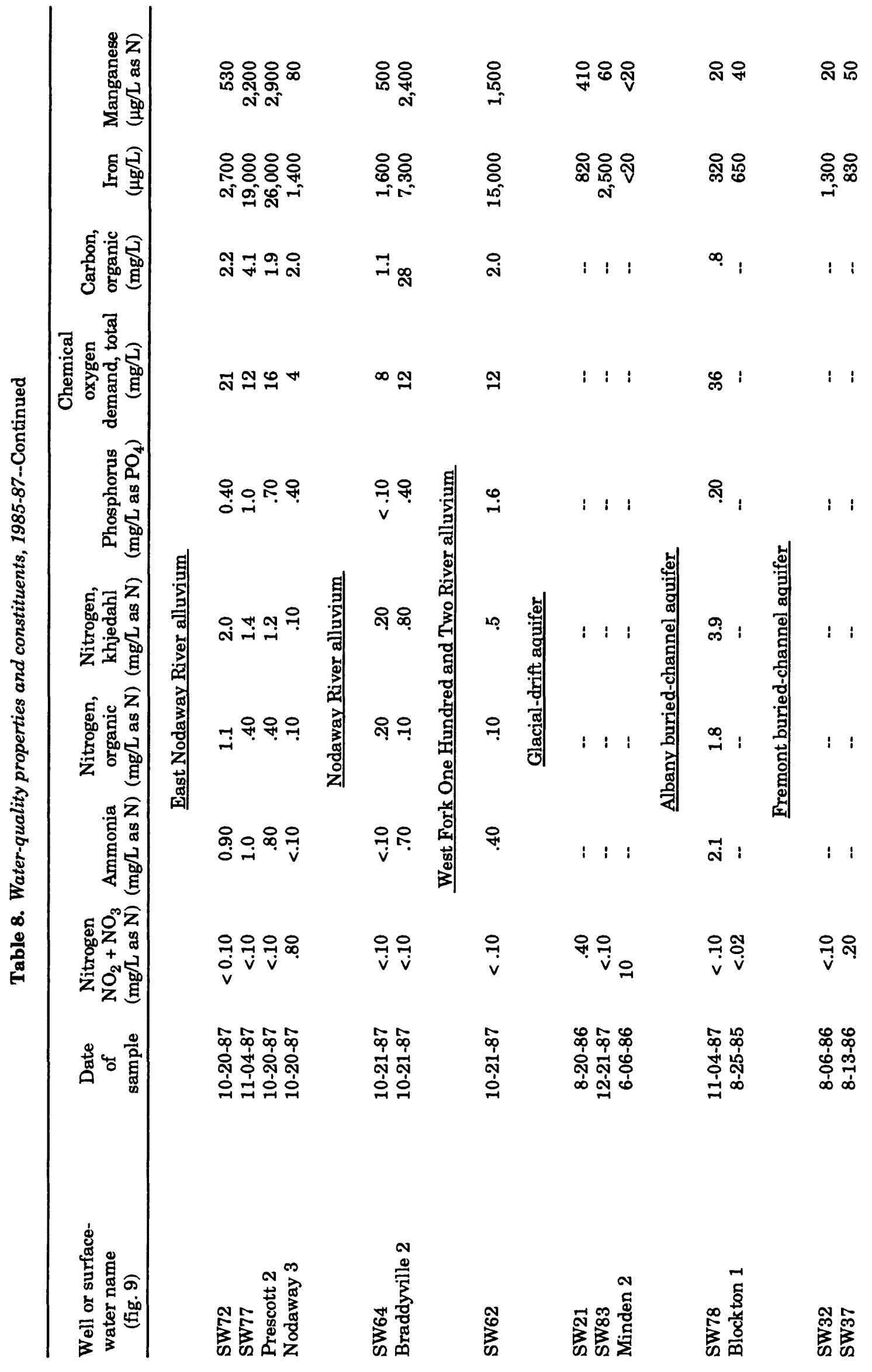




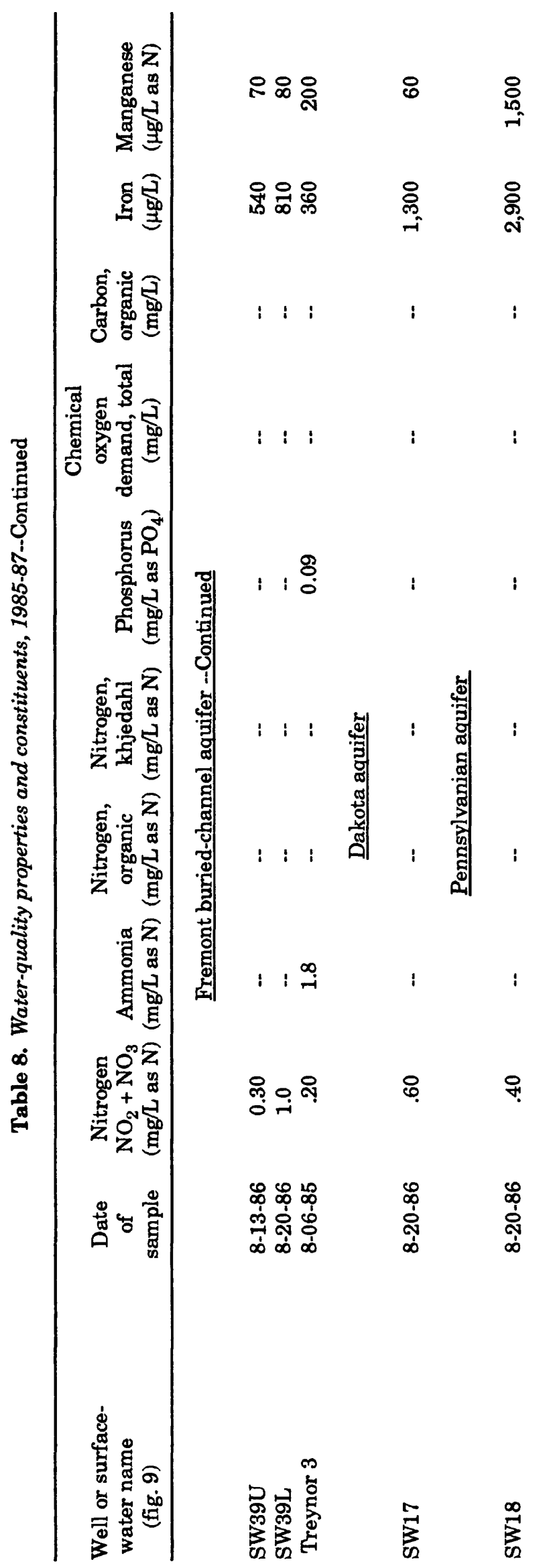




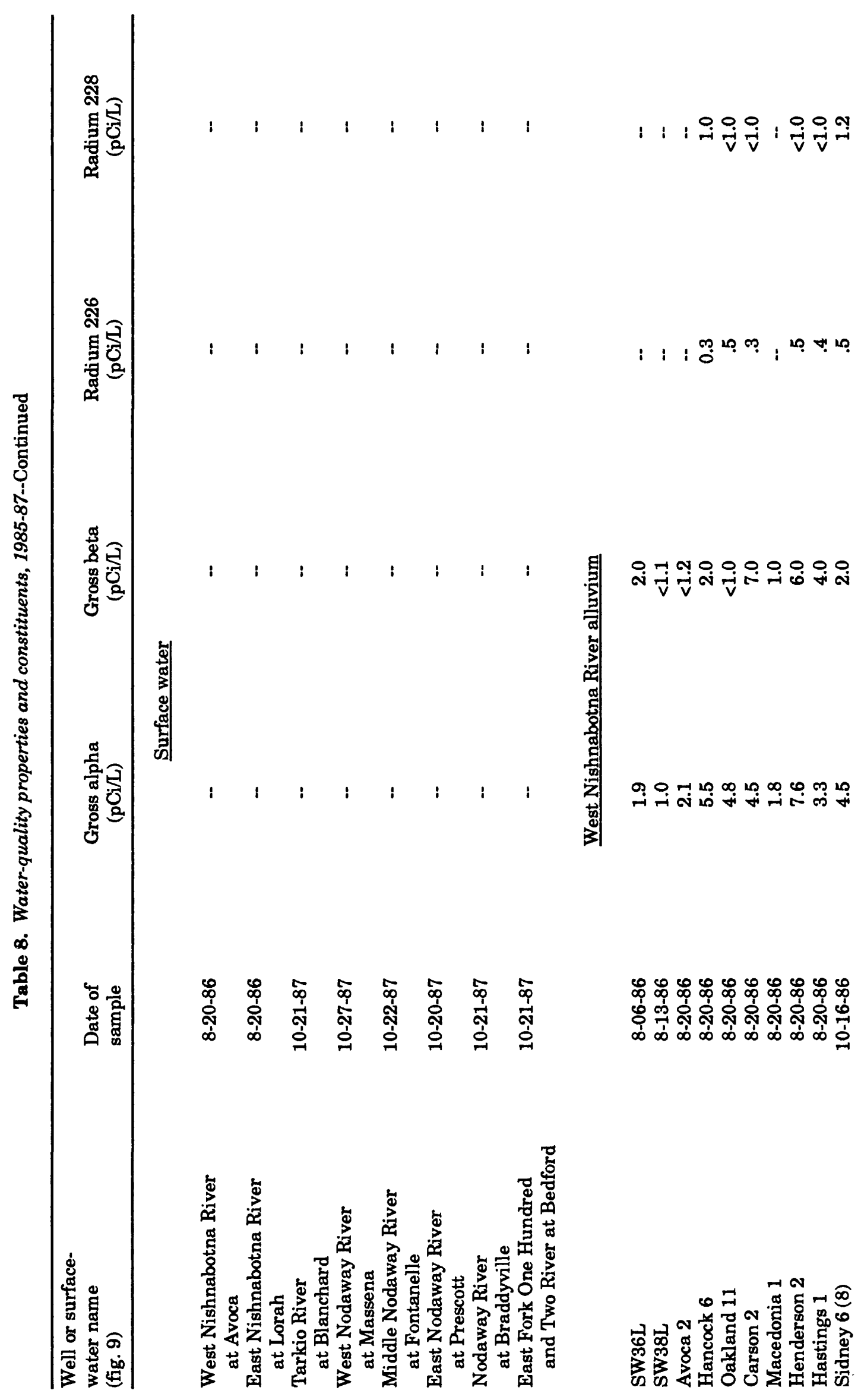




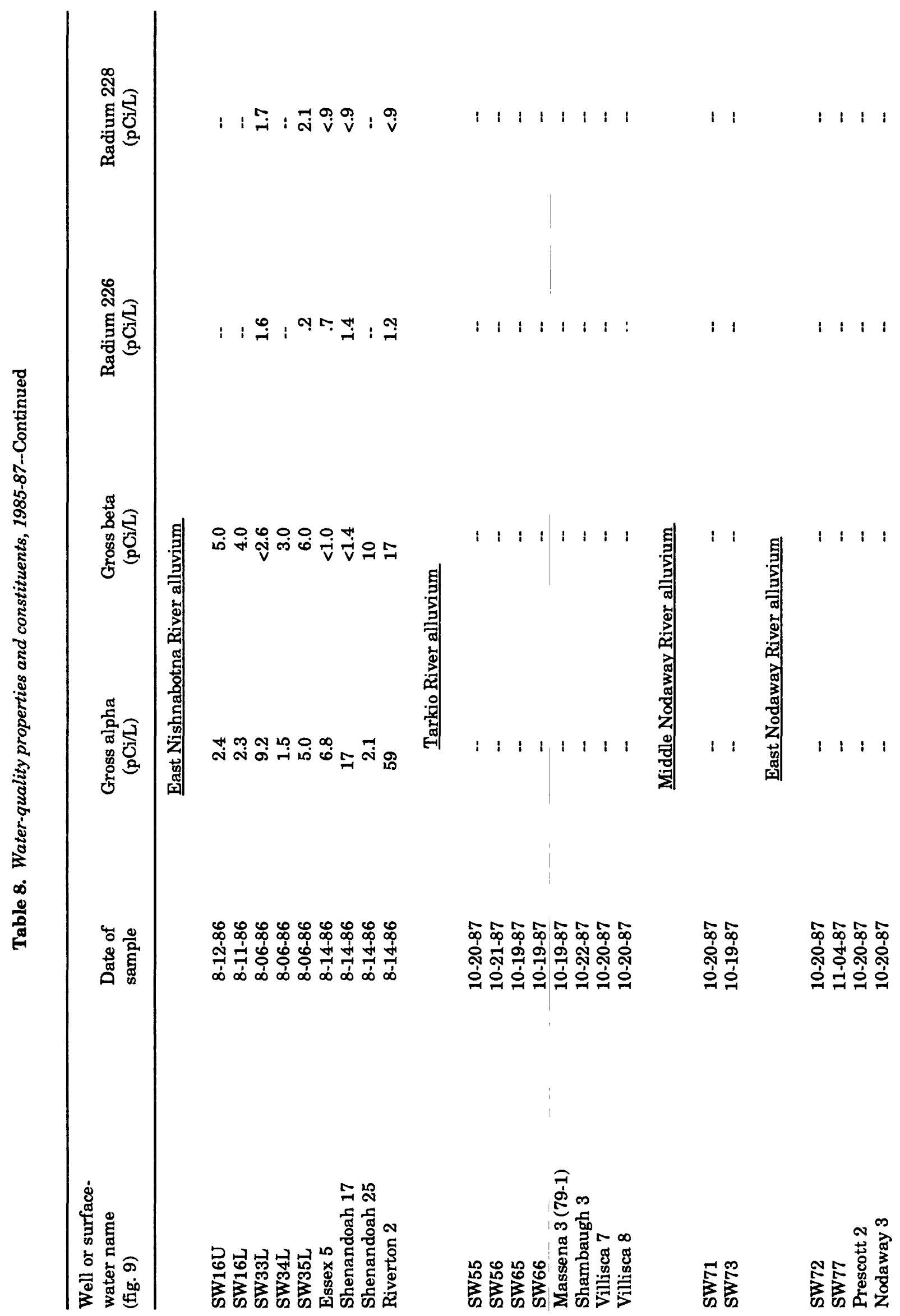




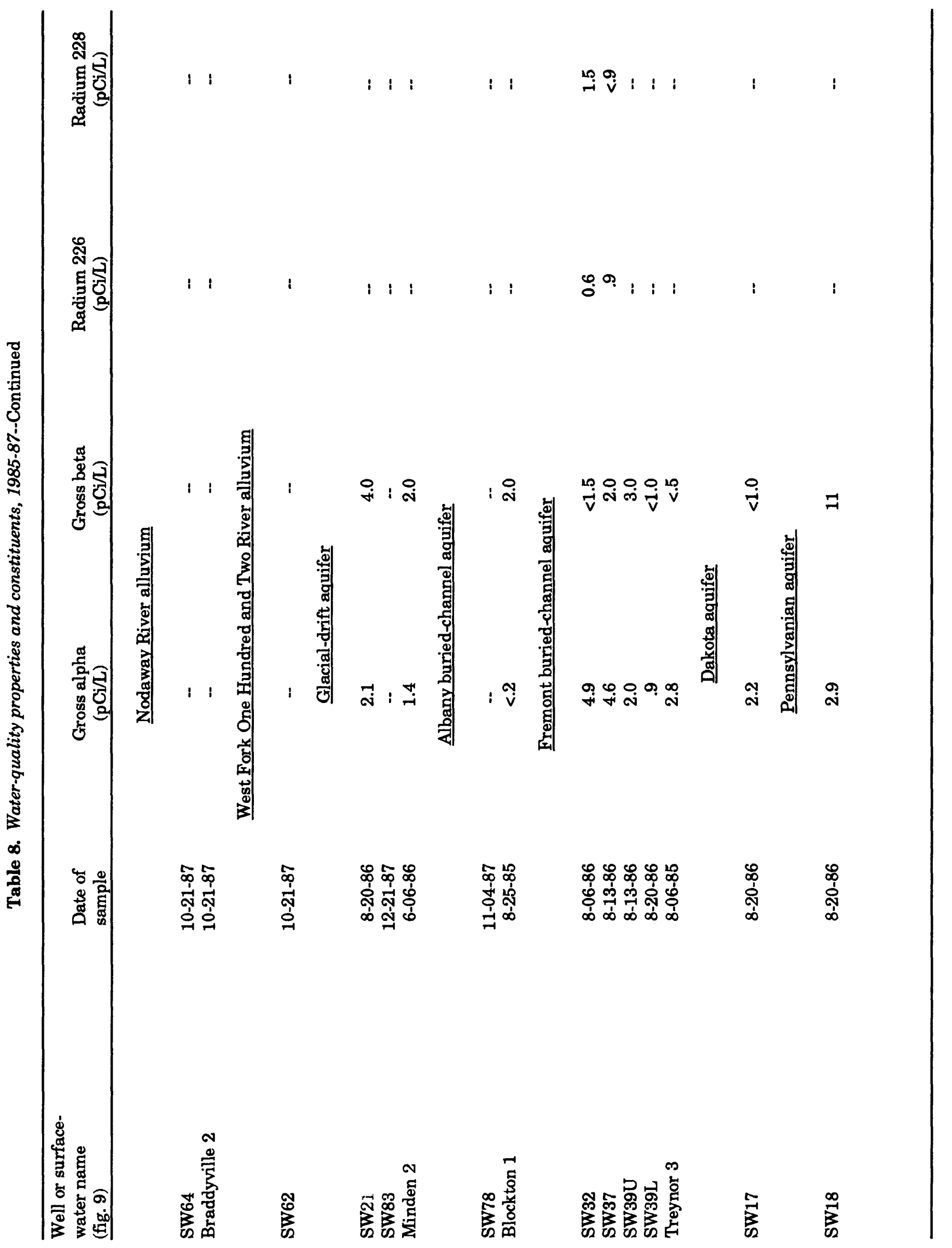

WATER-QUALITY PROPERTIES AND CONSTITUENTS, 1985-87 149 


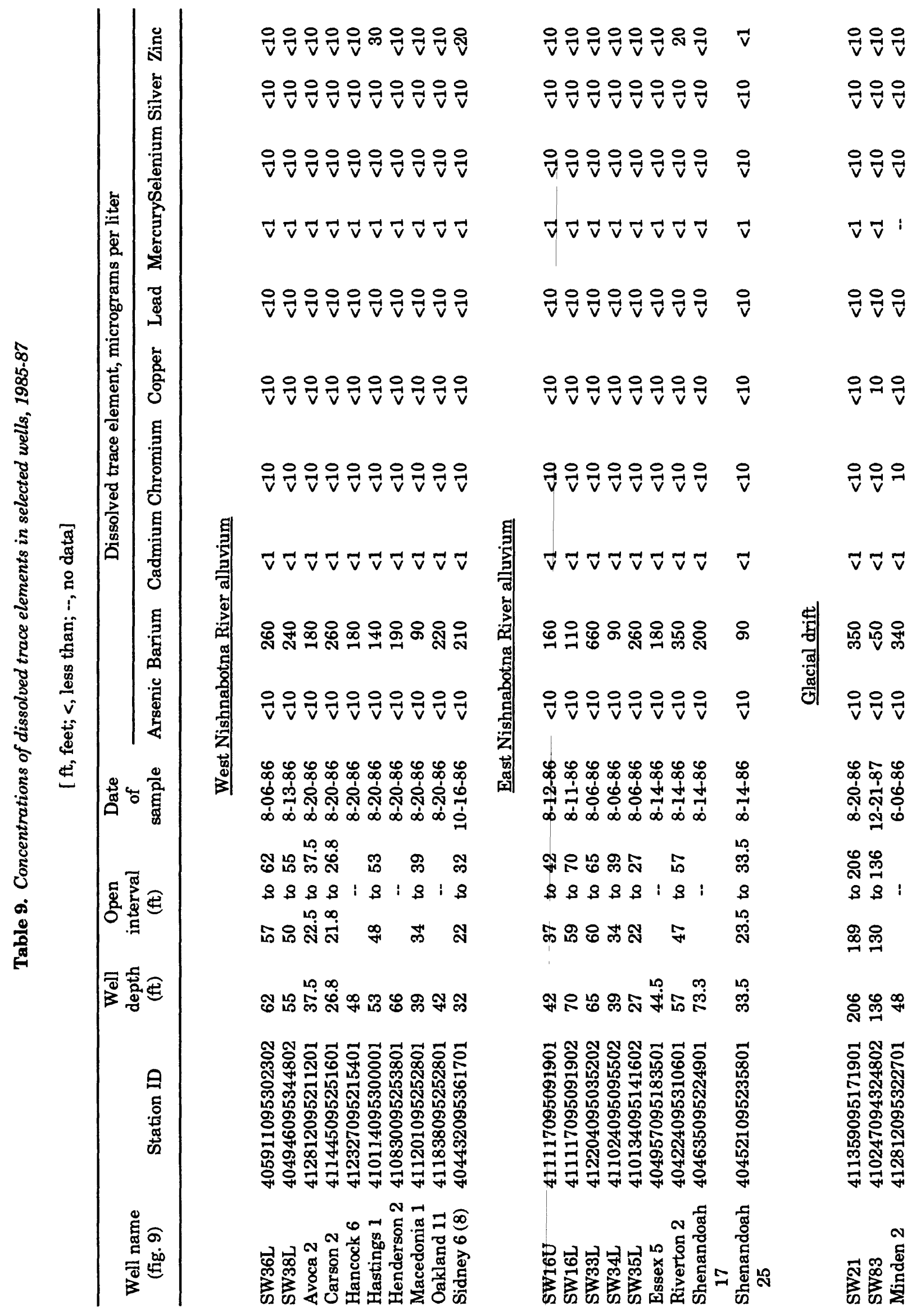




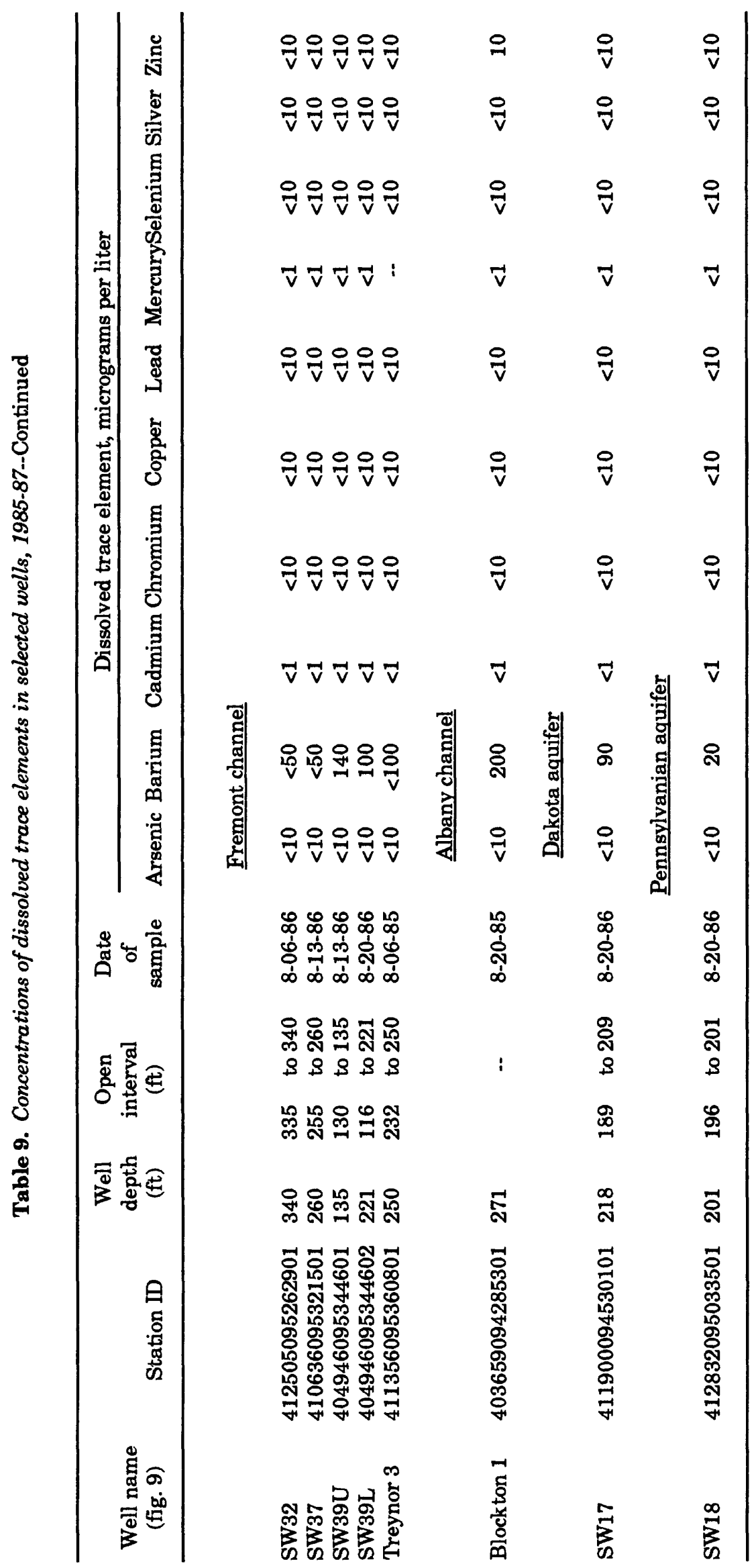




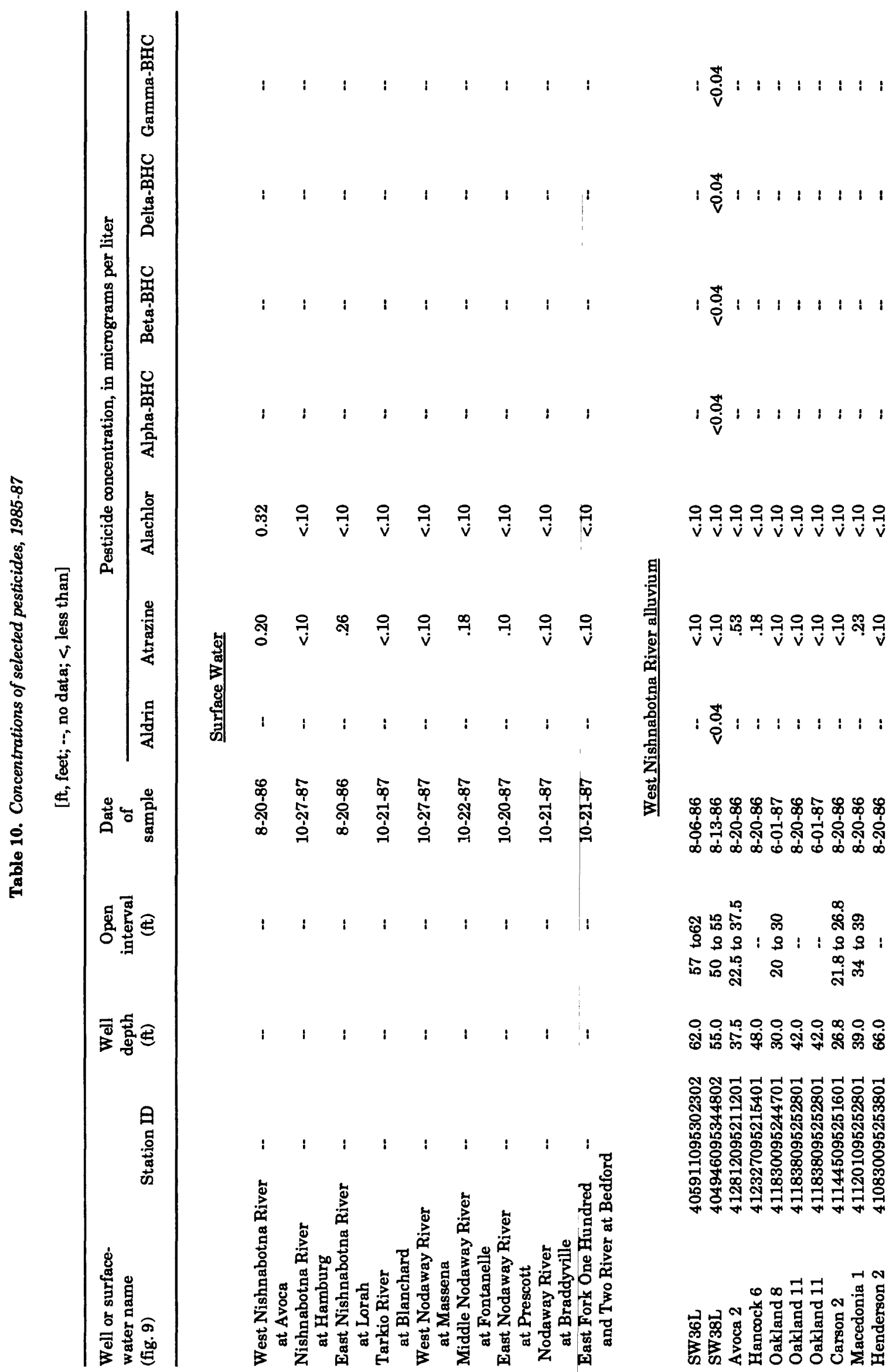




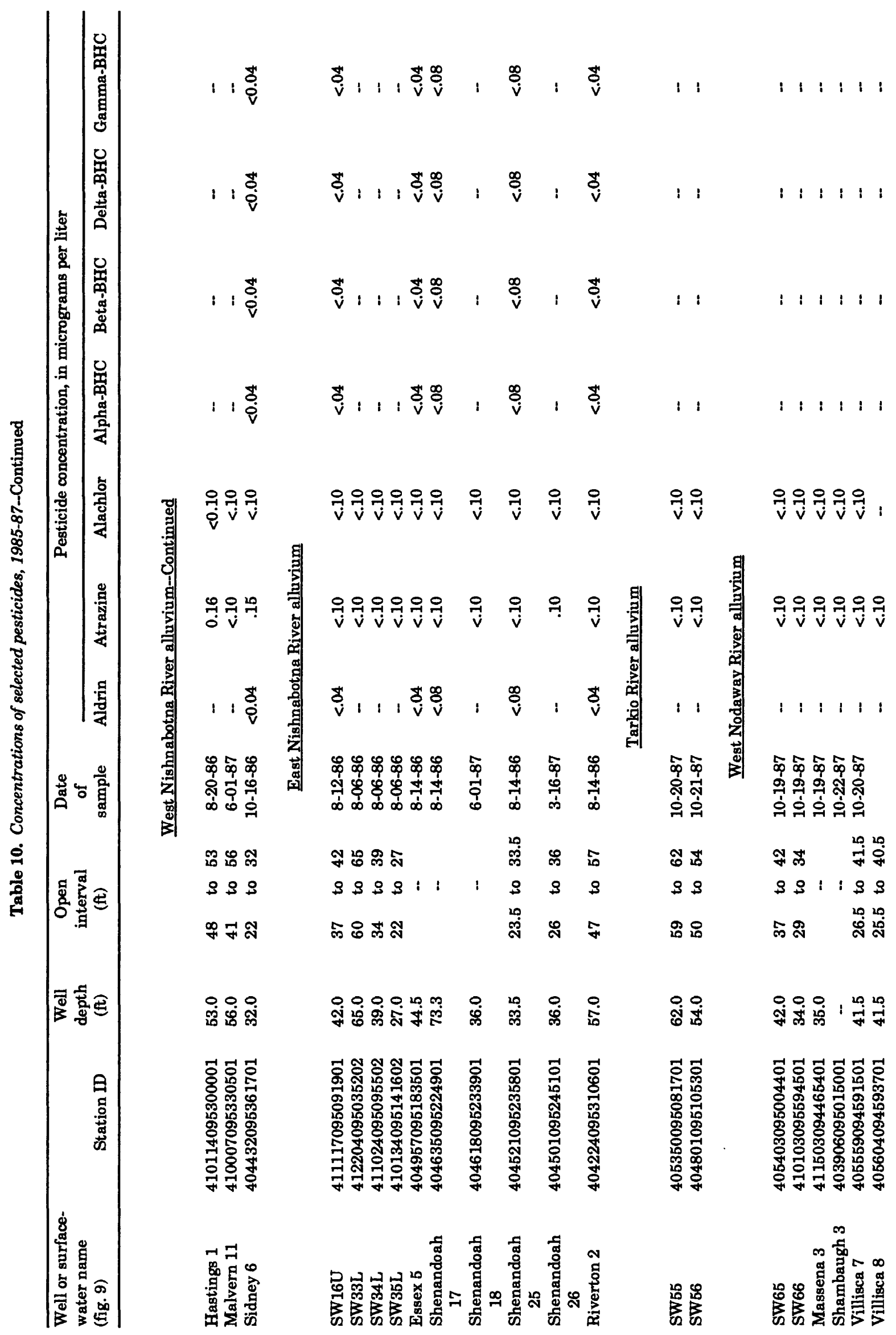




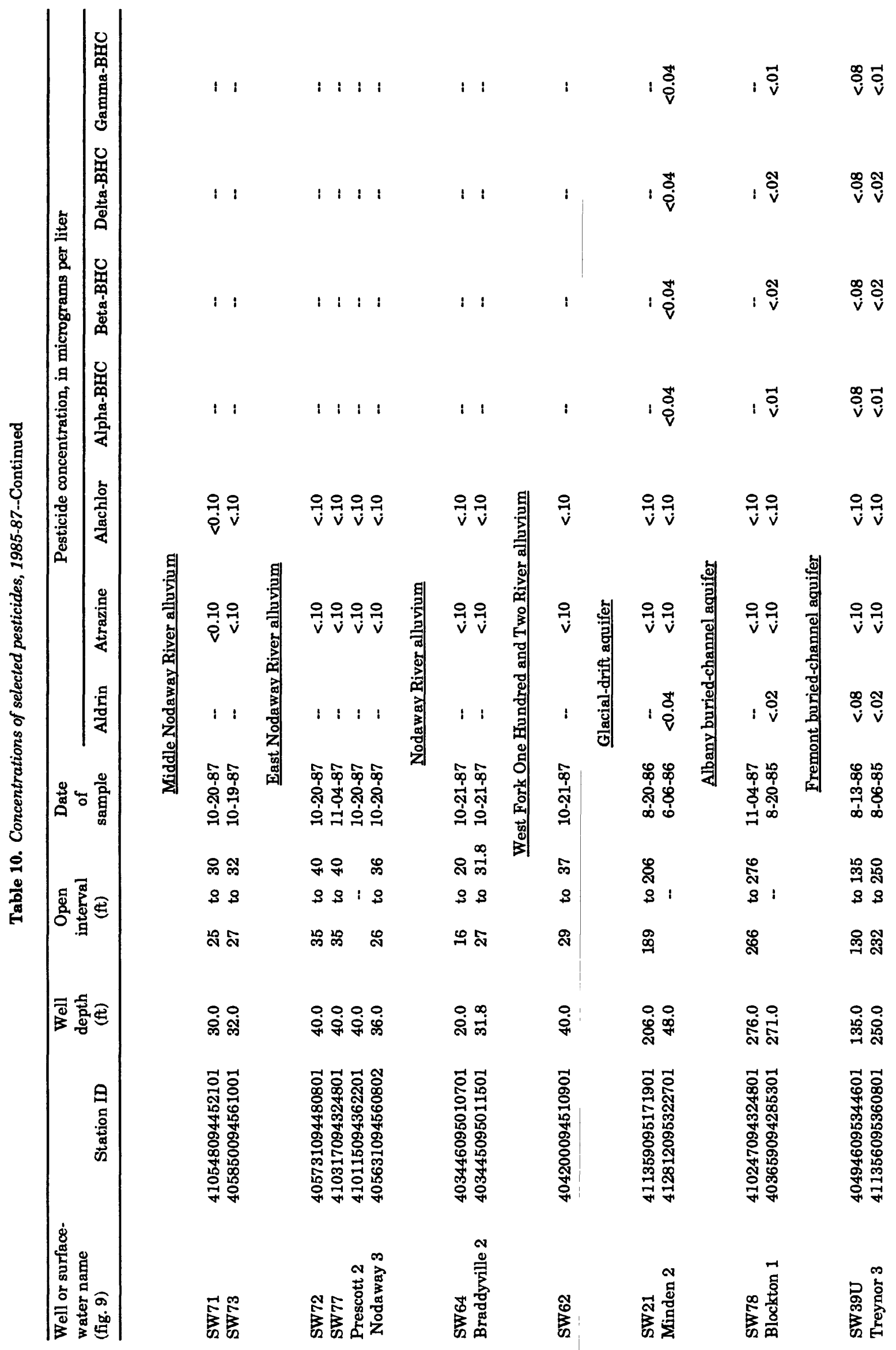




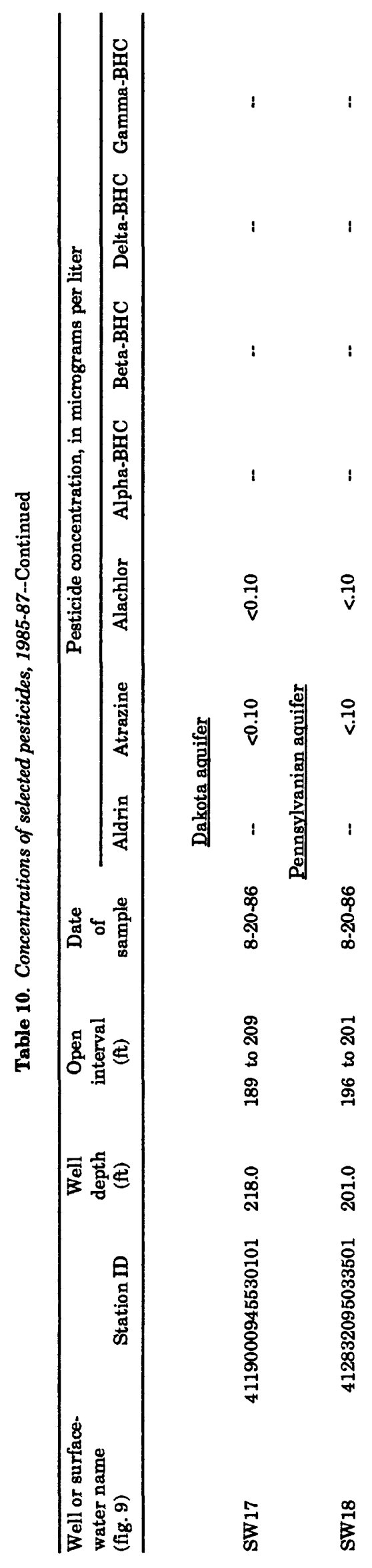




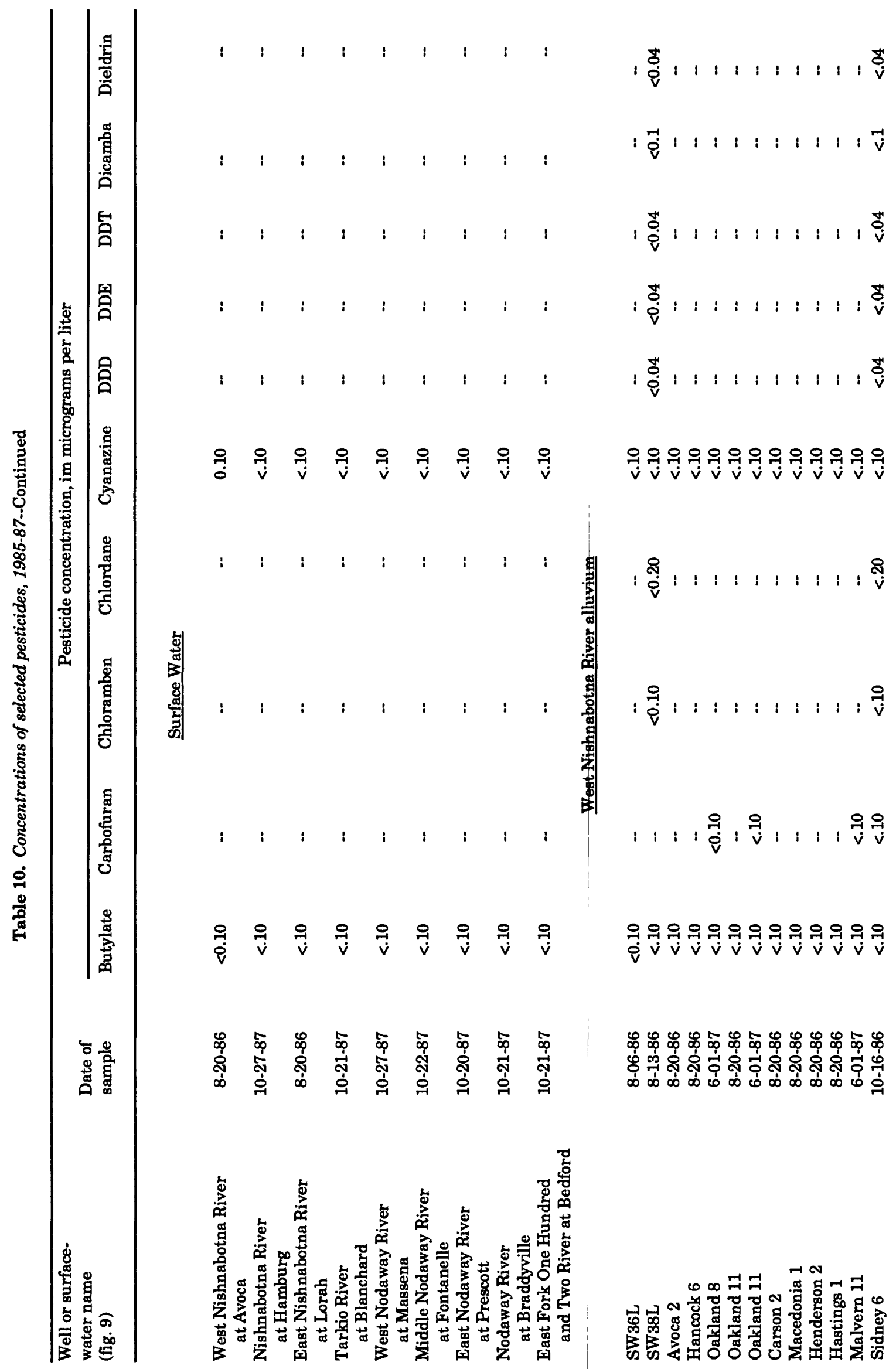




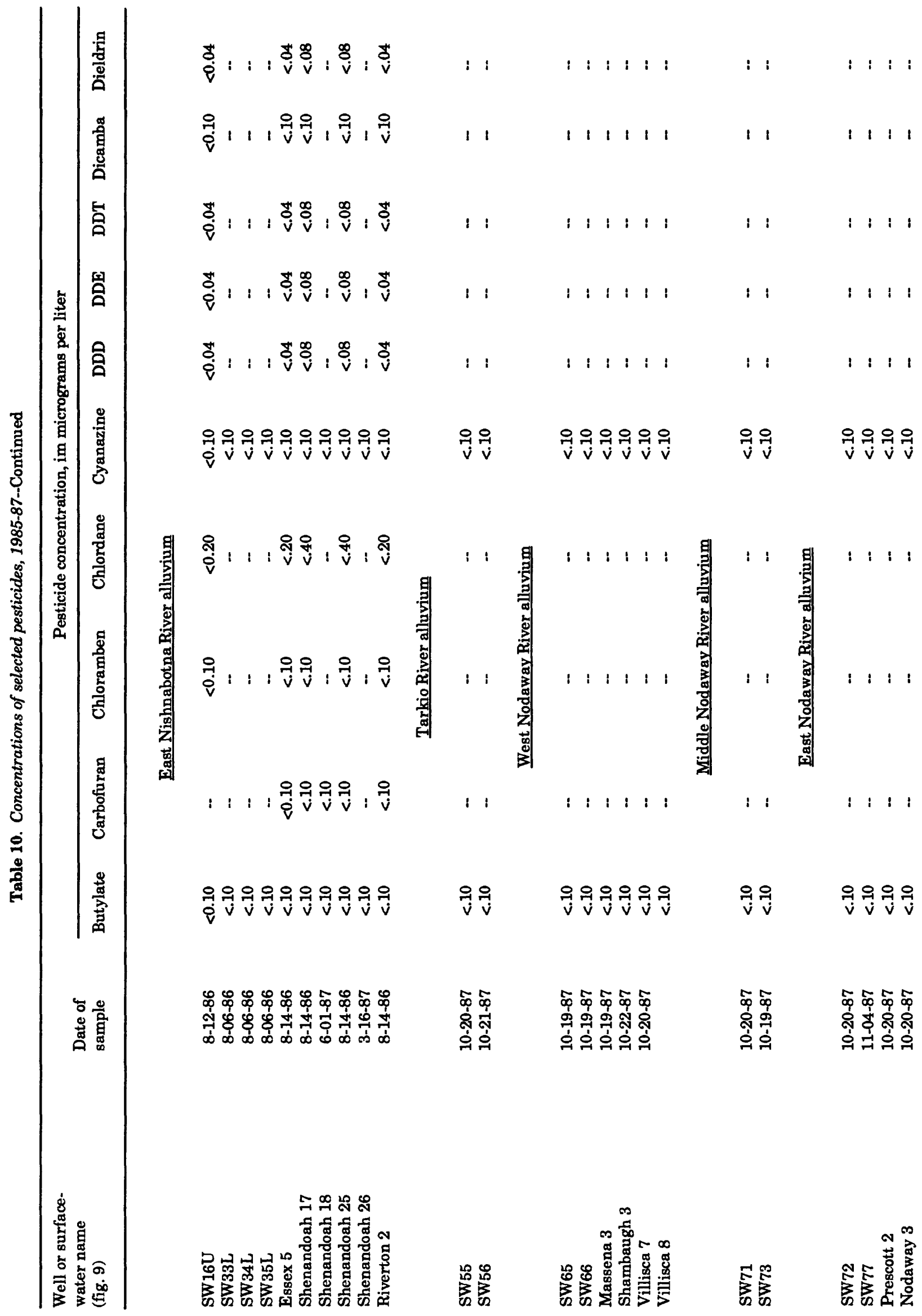




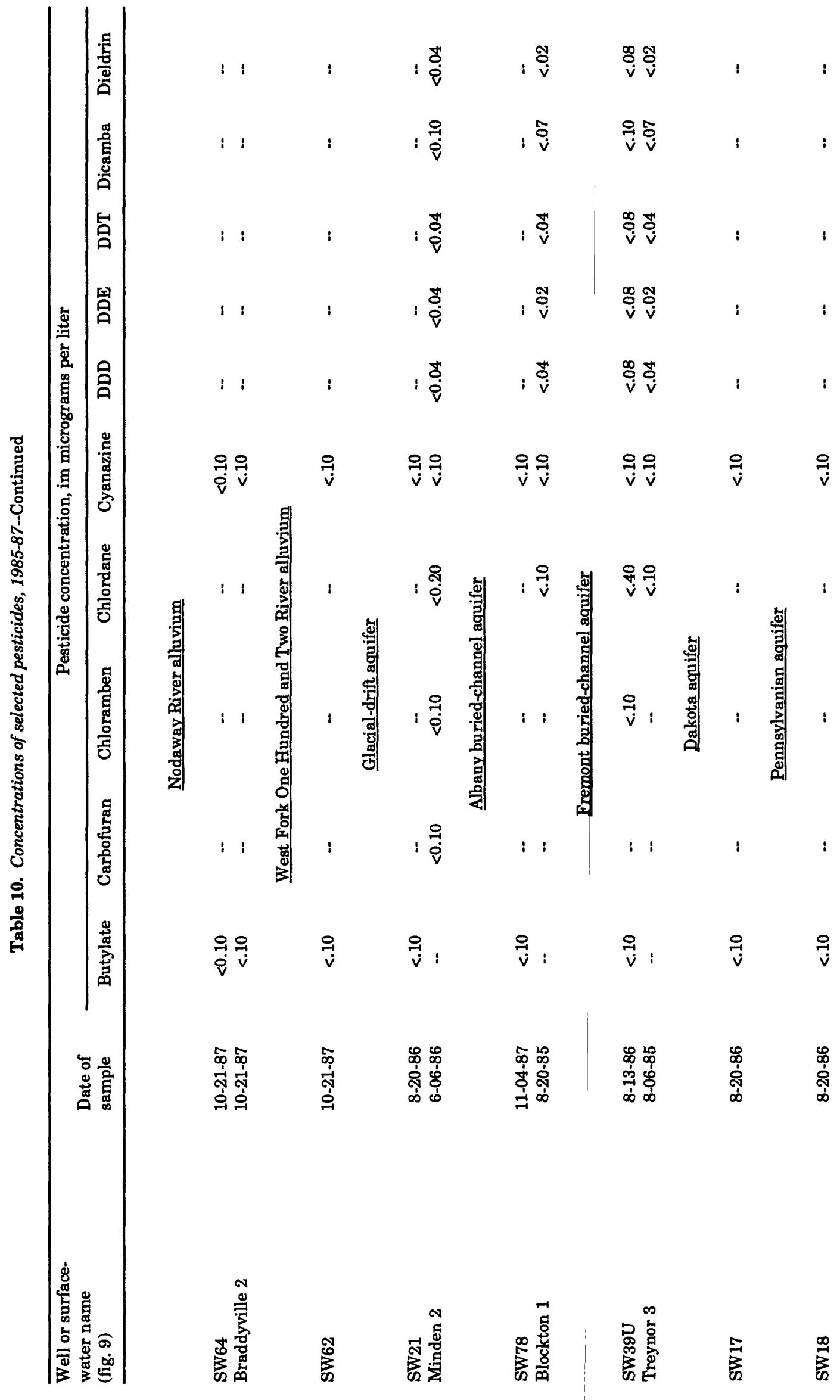




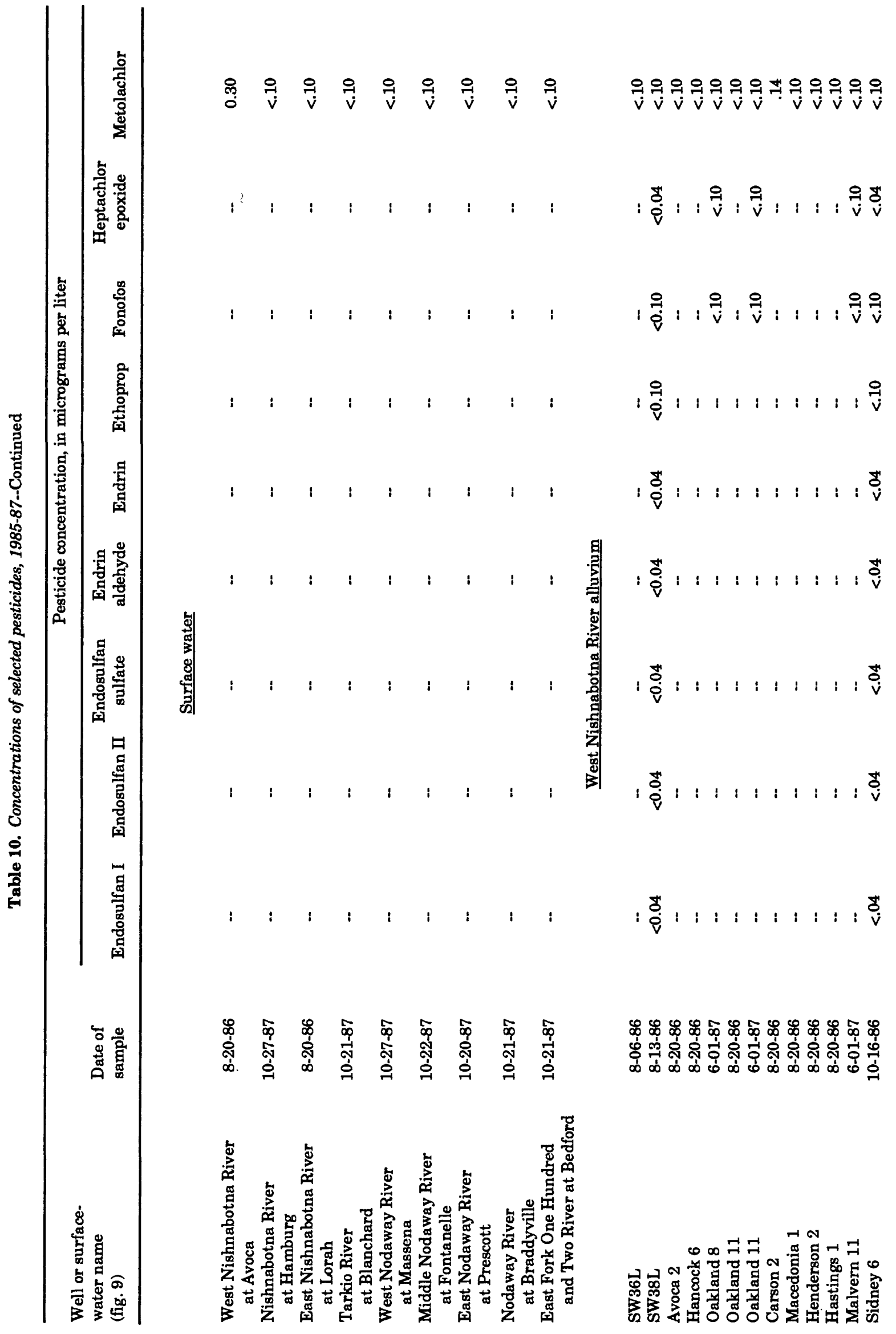




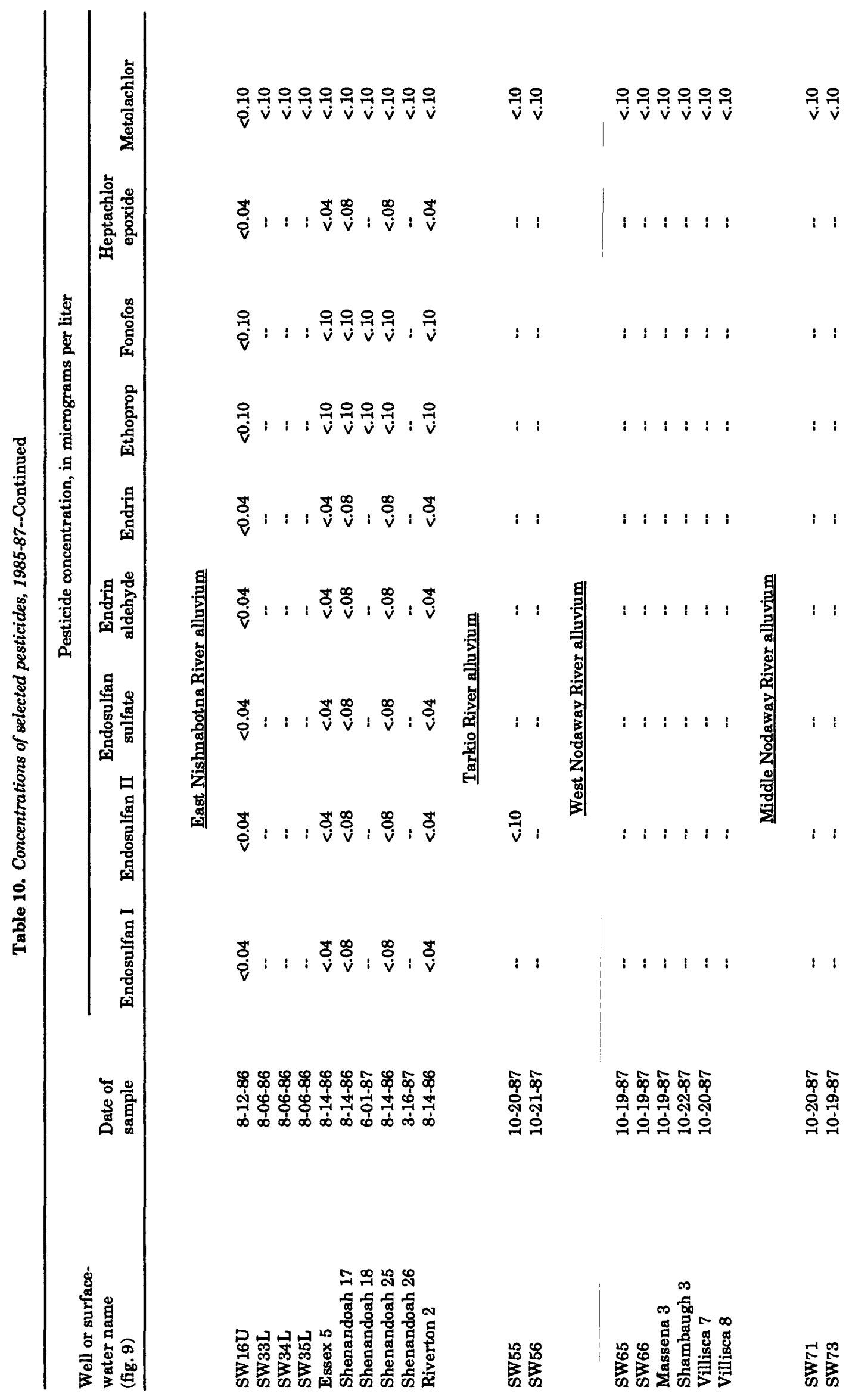




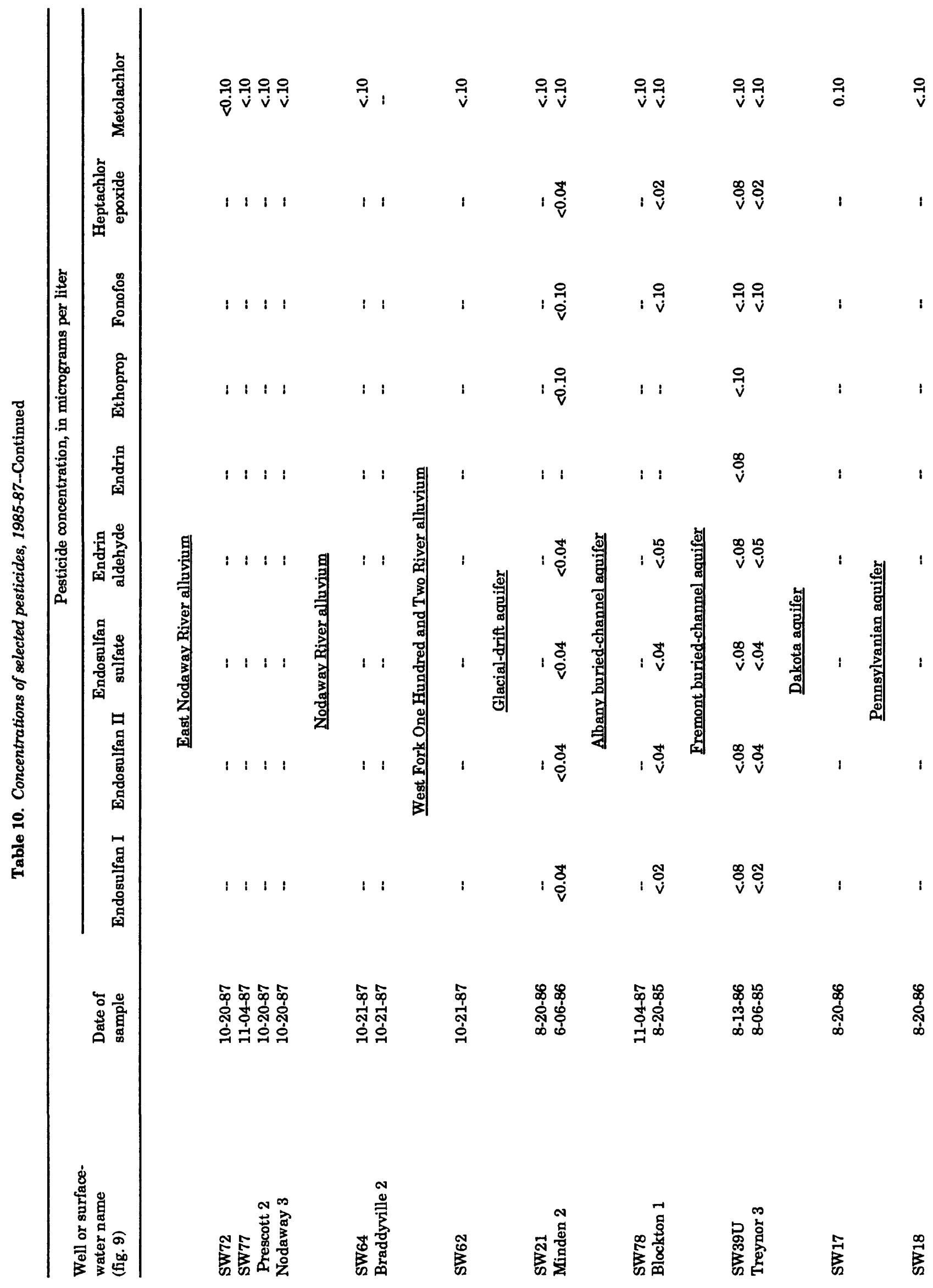




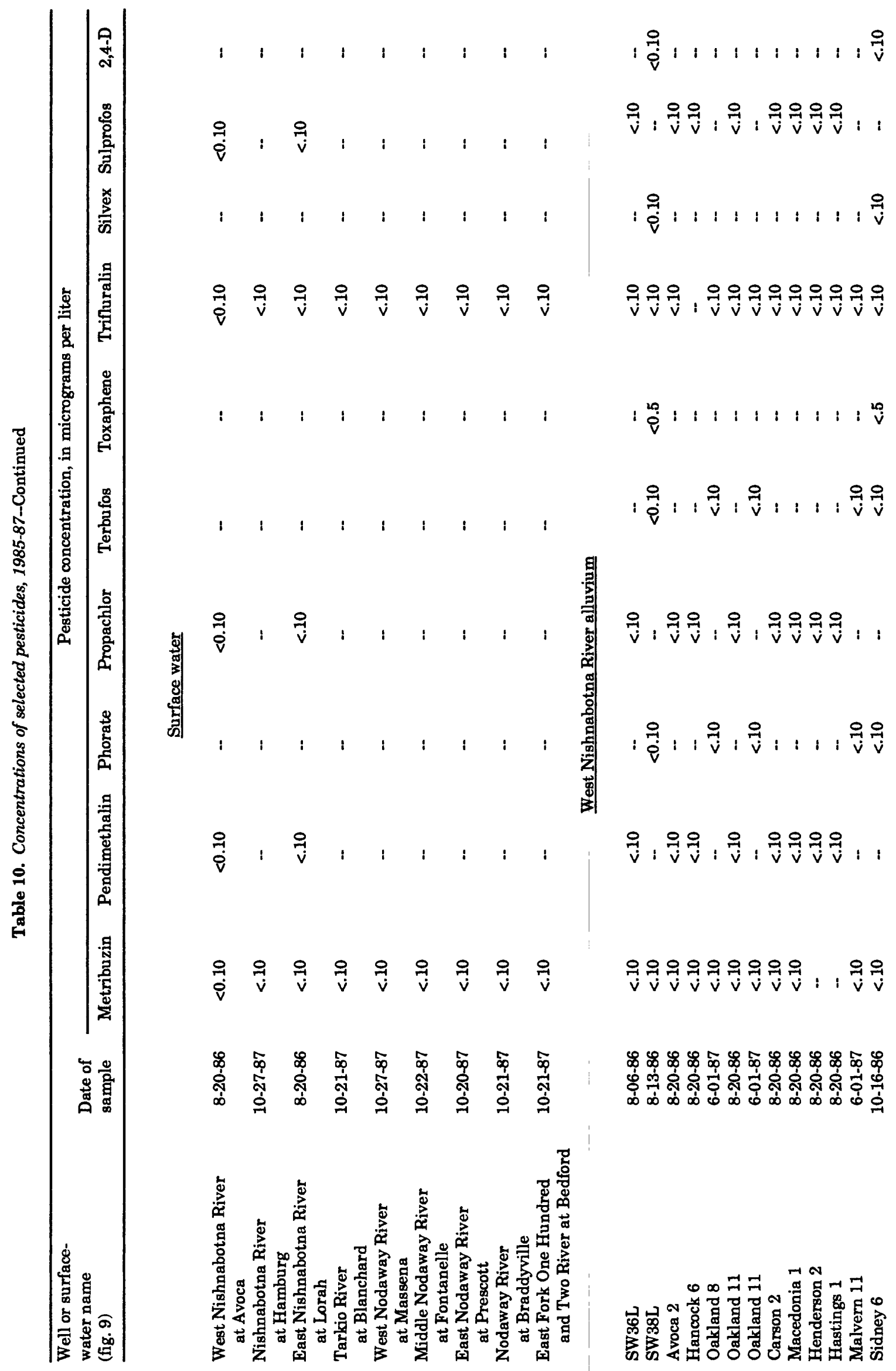




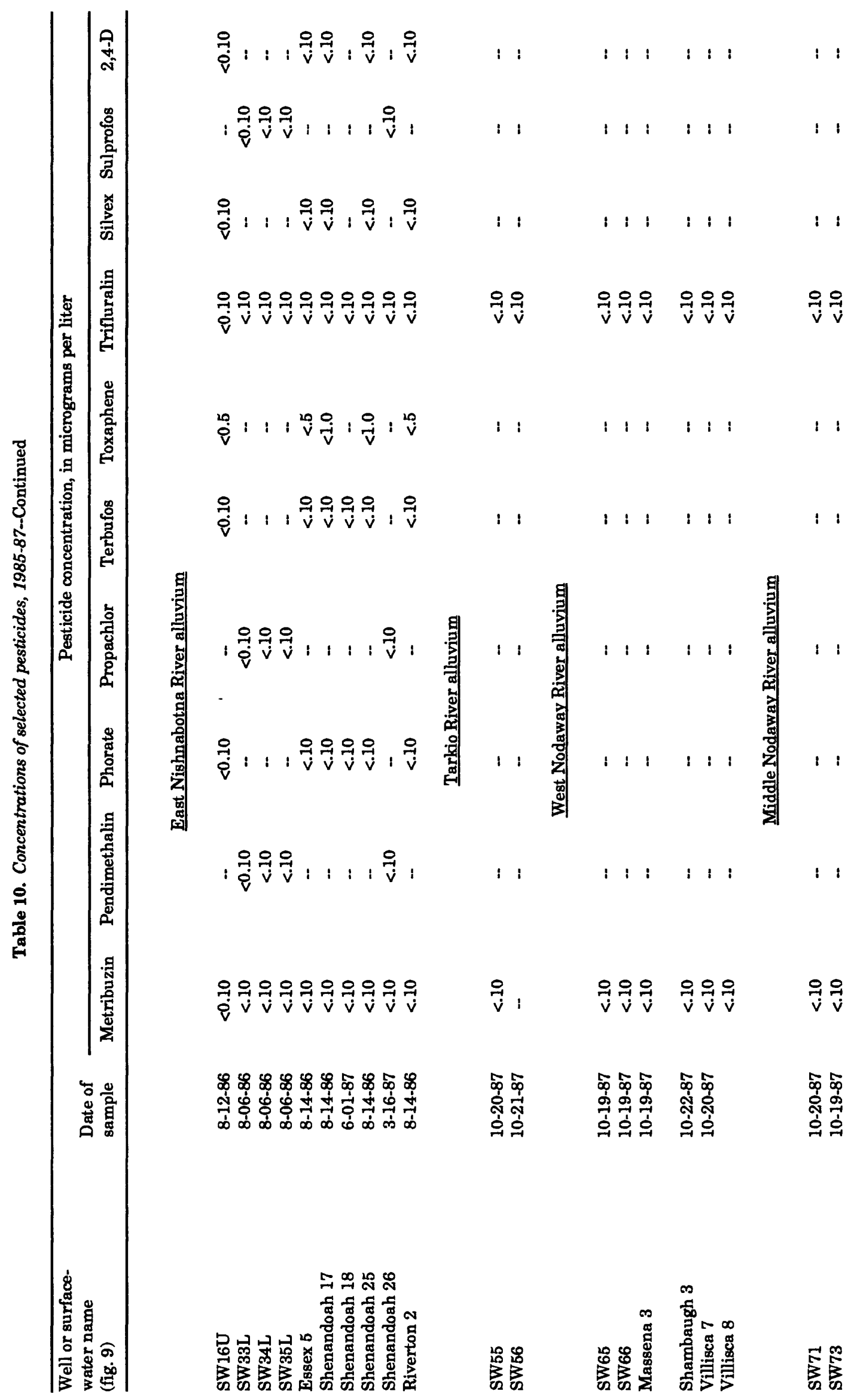




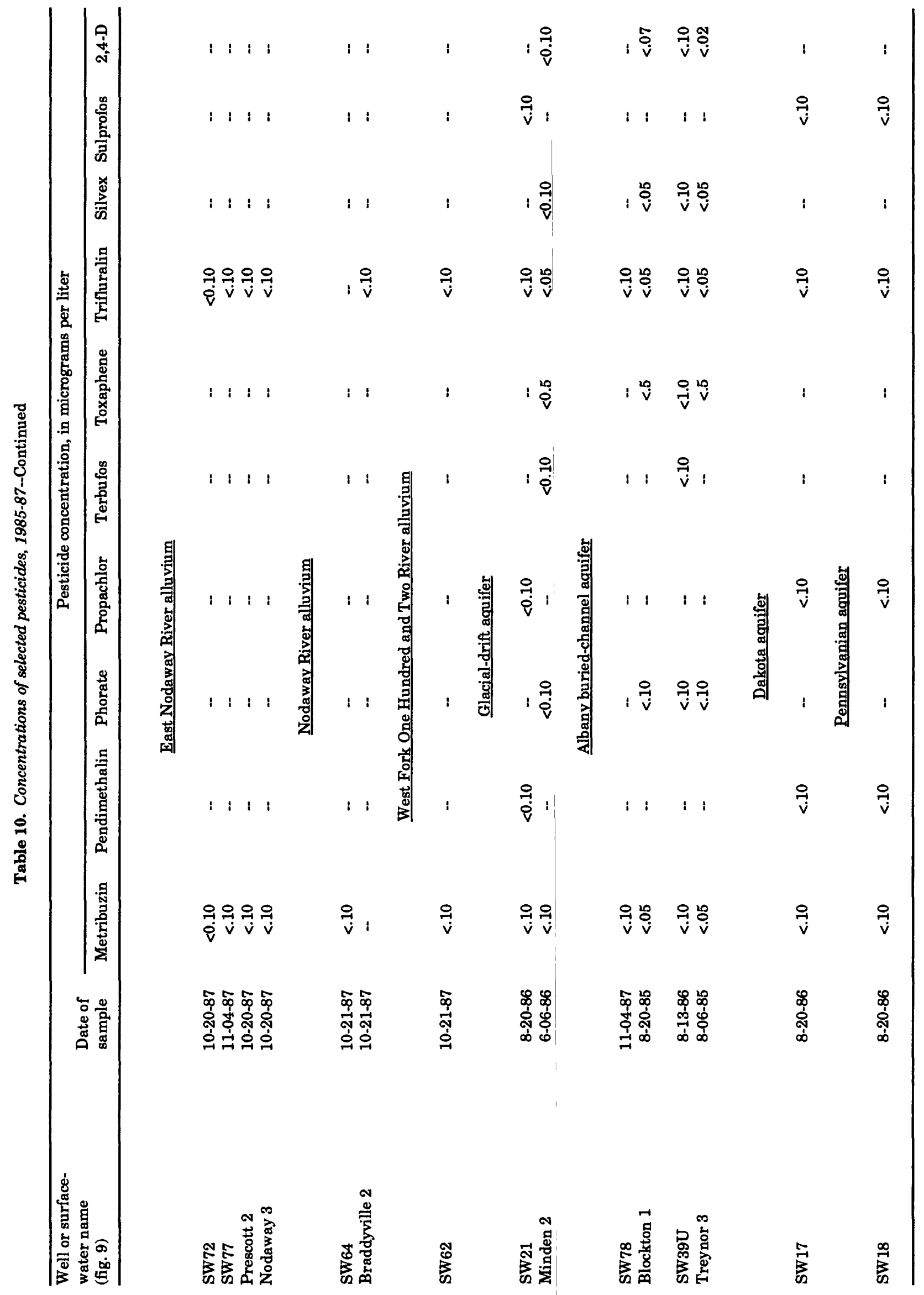




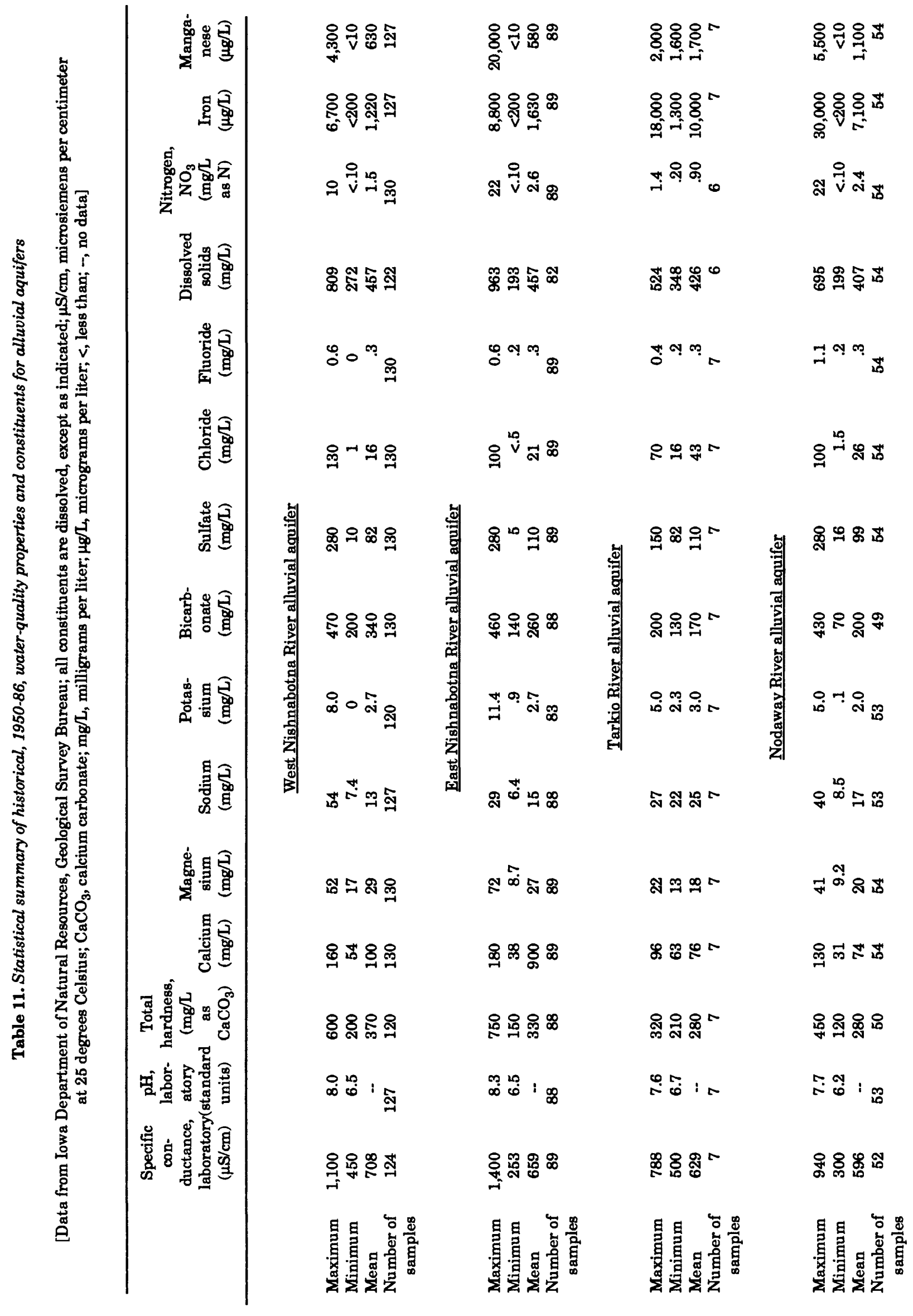




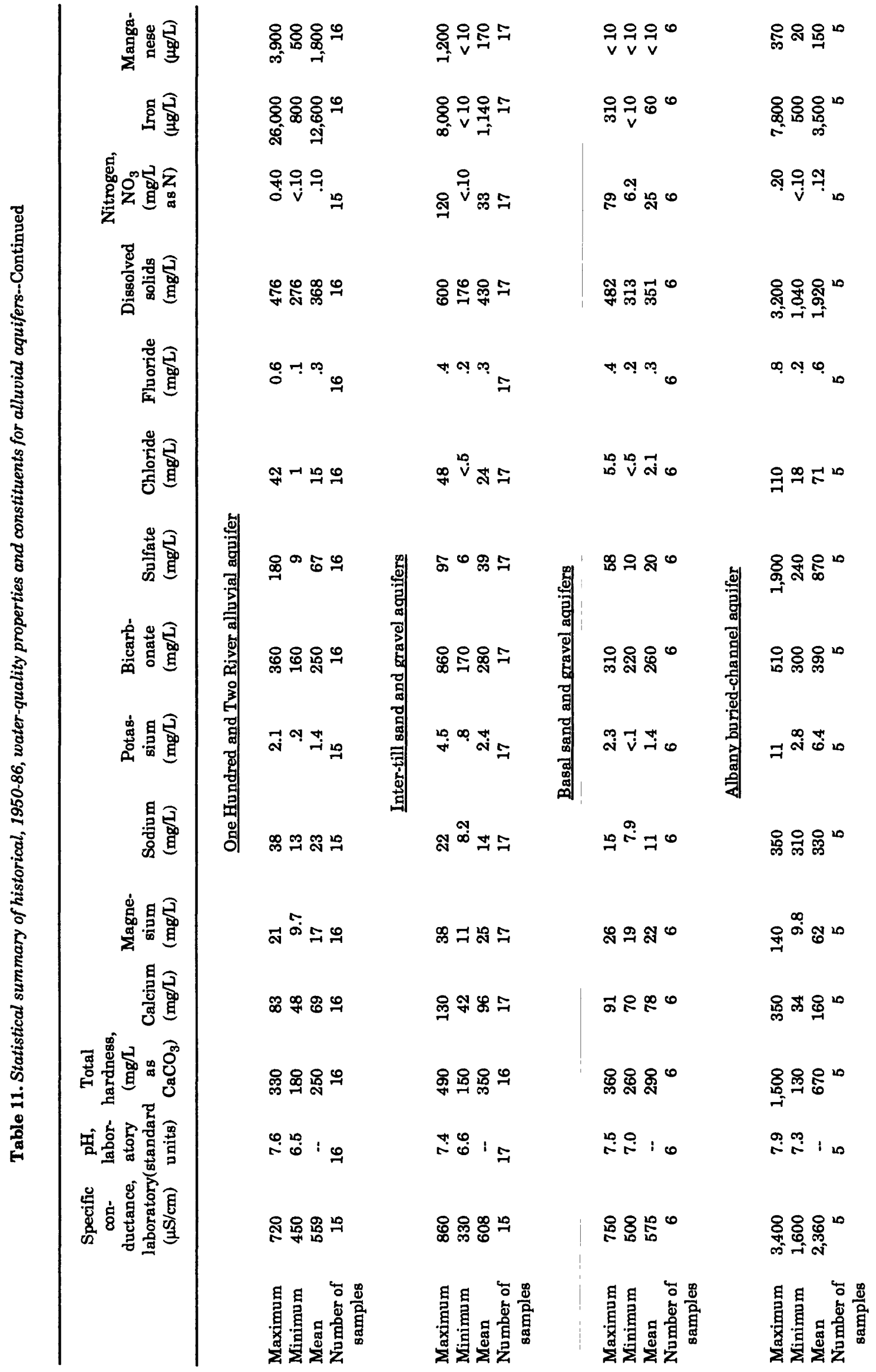




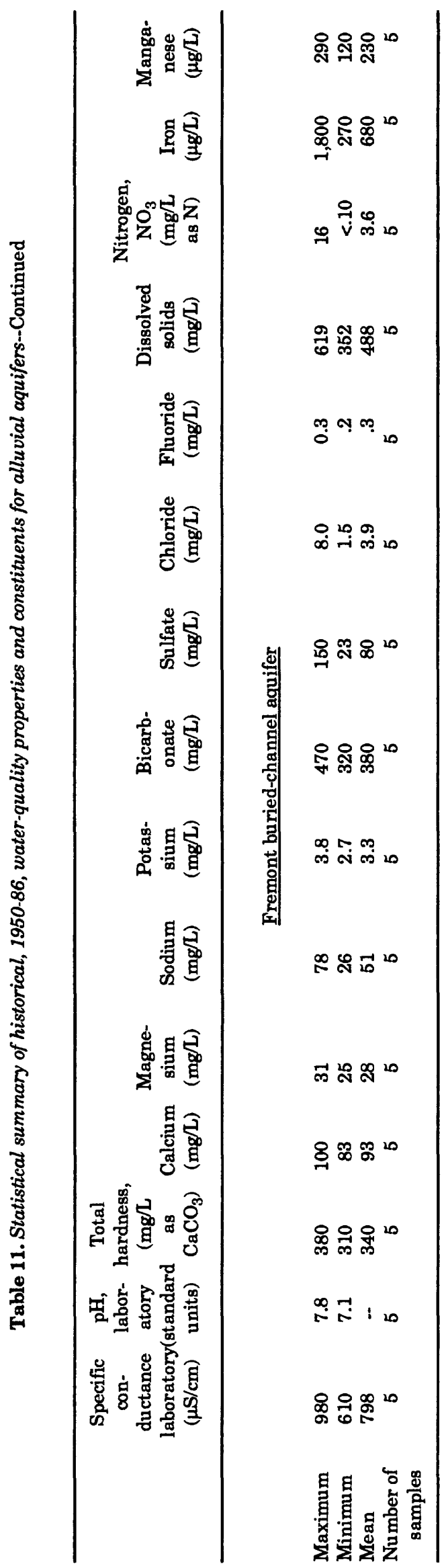




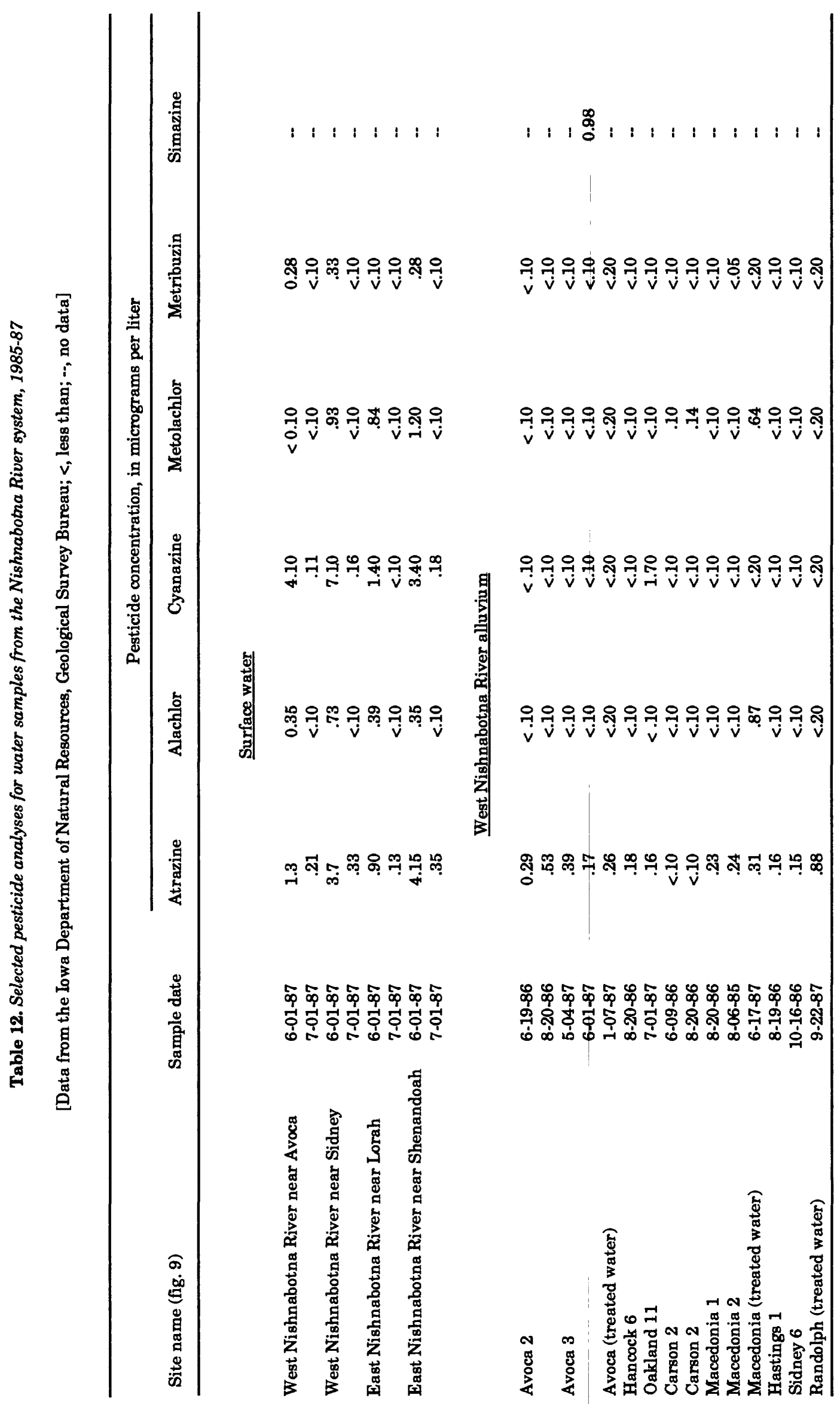


Table 13. Selected pesticide analyses for water samples from the Tarkio, Nodaway, and One Hundred and Two River systems, 1986-87

[Data from Iowa Department of Natural Resources, Geological Survey Bureau; <, less than; --, no data]

\begin{tabular}{|c|c|c|c|c|c|c|}
\hline \multirow[b]{2}{*}{ Site name (fig. 9) } & \multirow[b]{2}{*}{ Sample date } & \multicolumn{5}{|c|}{ Pesticide concentration, in micrograms per liter } \\
\hline & & Atrazine & Alachlor & Cyanazine & Metolachlor & 2,4-D \\
\hline \multicolumn{7}{|c|}{ Surface water } \\
\hline $\begin{array}{l}\text { Middle Nodaway River } \\
\text { at Fontanelle }\end{array}$ & $10-22-87$ & 0.10 & $<0.10$ & $<0.10$ & $<0.10$ & -- \\
\hline $\begin{array}{l}\text { East Nodaway River } \\
\text { at Prescott }\end{array}$ & $10-20-87$ & .10 & $<.10$ & $<.10$ & $<.10$ & -- \\
\hline \multicolumn{7}{|c|}{ Tarkio River alluvium } \\
\hline $\begin{array}{l}\text { Blanchard } \\
\text { (treated water) }\end{array}$ & $11-18-86$ & .25 & $<.20$ & $<.20$ & $<.20$ & $<0.20$ \\
\hline \multicolumn{7}{|c|}{ Middle Nodaway River alluvium } \\
\hline Fontanelle 5 & $\begin{array}{l}8-15-86 \\
4-04-87\end{array}$ & $\begin{array}{l}.28 \\
.11\end{array}$ & $\begin{array}{r}.10 \\
<.10\end{array}$ & $\begin{array}{l}<.10 \\
<.10\end{array}$ & $\begin{array}{l}<.10 \\
<.10\end{array}$ & $<.10$ \\
\hline \multicolumn{7}{|c|}{ One Hundred and Two River alluvium } \\
\hline Gravity 3 & $7-11-86$ & $<.10$ & .32 & $<.10$ & .36 & $<.10$ \\
\hline $\begin{array}{l}\text { Gravity } \\
\quad \text { (treated water) }\end{array}$ & $4-13-87$ & $<.20$ & $<.20$ & $<.20$ & $<.20$ & .25 \\
\hline \multirow[t]{2}{*}{ Conway 1} & $7-18-86$ & .31 & .73 & $<.10$ & $<.10$ & $<.10$ \\
\hline & 8-04-87 & 1.4 & 2.1 & $<.10$ & $<.10$ & -. \\
\hline Conway & $11-12-86$ & $<.20$ & 1.1 & $<.20$ & $<.20$ & $<.20$ \\
\hline
\end{tabular}

Table 14. Thickness of glacial drift in southwest Iowa

\begin{tabular}{lc}
\hline County & $\begin{array}{c}\text { Thickness } \\
\text { (feet) }\end{array}$ \\
\hline Adair & $50-293$ \\
Adams & $11-329$ \\
Cass & $18-260$ \\
Fremont & $24-398$ \\
Mills & $40-263$ \\
Montgomery & $6-230$ \\
Page & $25-220$ \\
Pottawattamie & $6-452$ \\
Taylor & $20-274$ \\
\hline
\end{tabular}


Table 15. Water levels and potential yields of the Dakota aquifer

[ft, feet; gal/min, gallons per minute; $\mathrm{ft}^{2} / \mathrm{d}$, feet squared per day; >, greater than; --, no data]

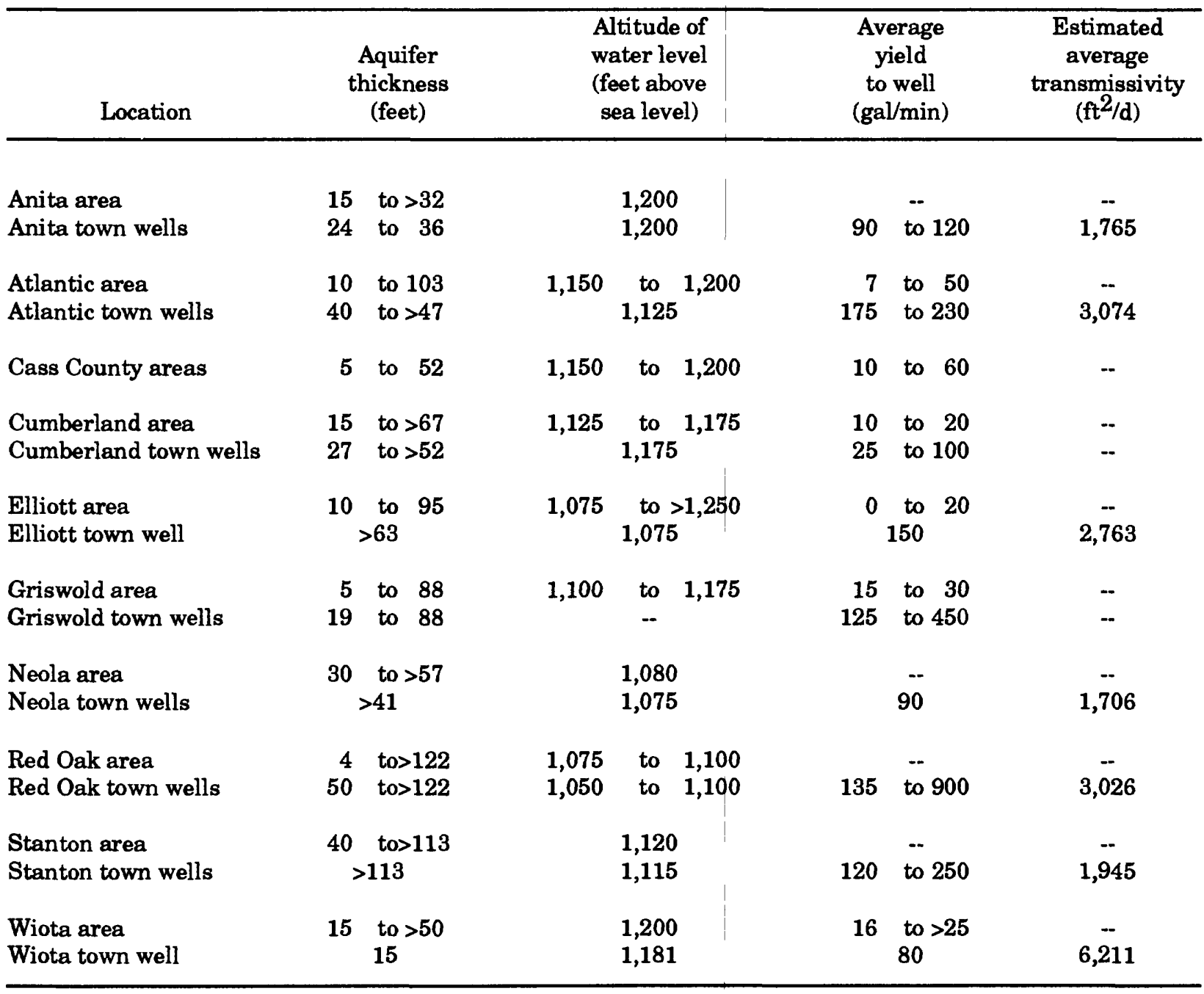




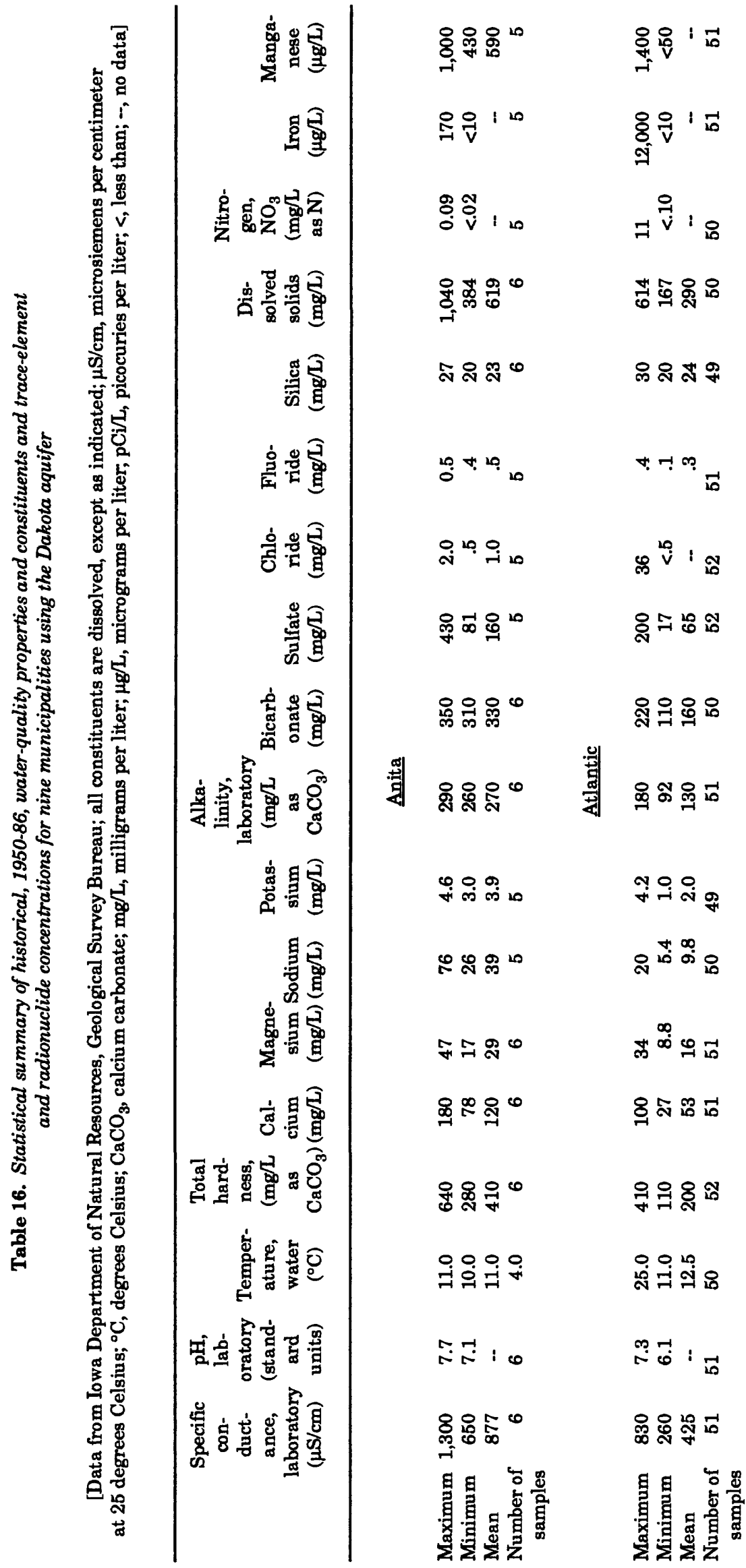




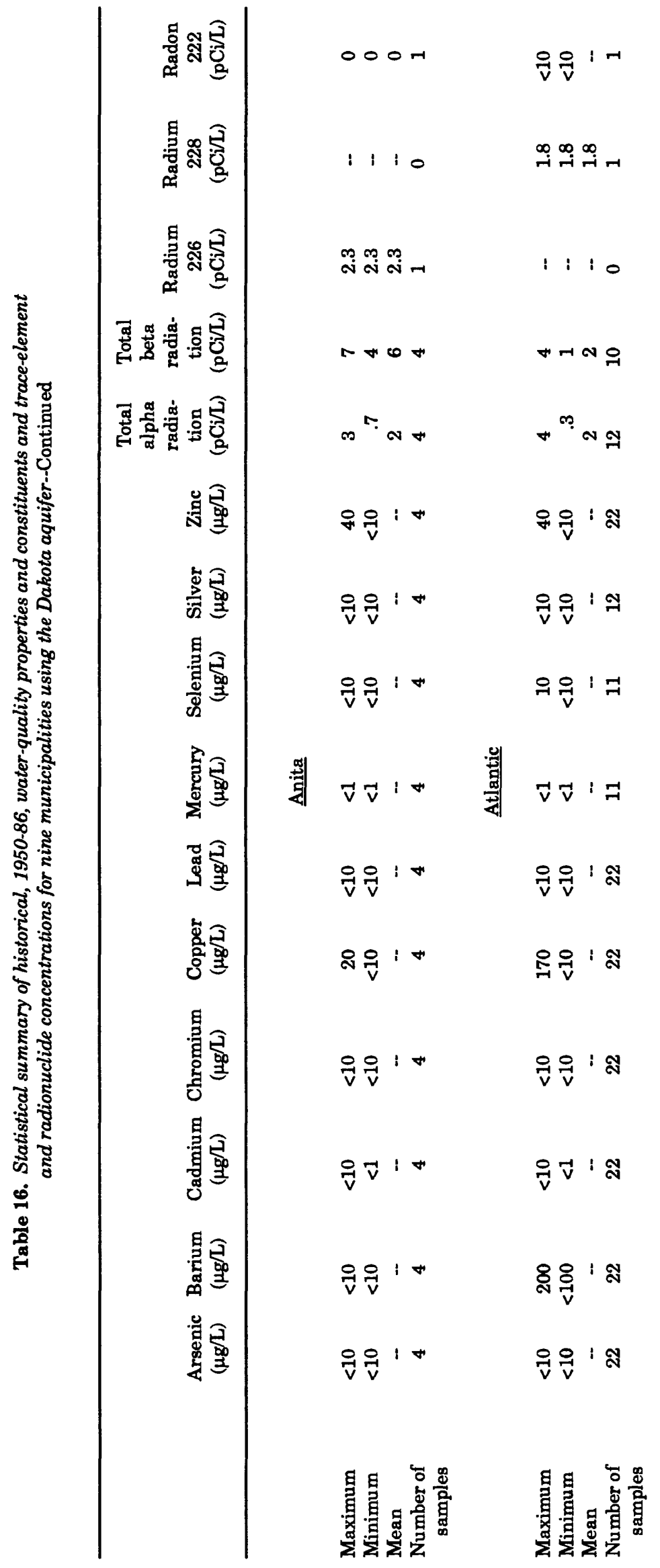




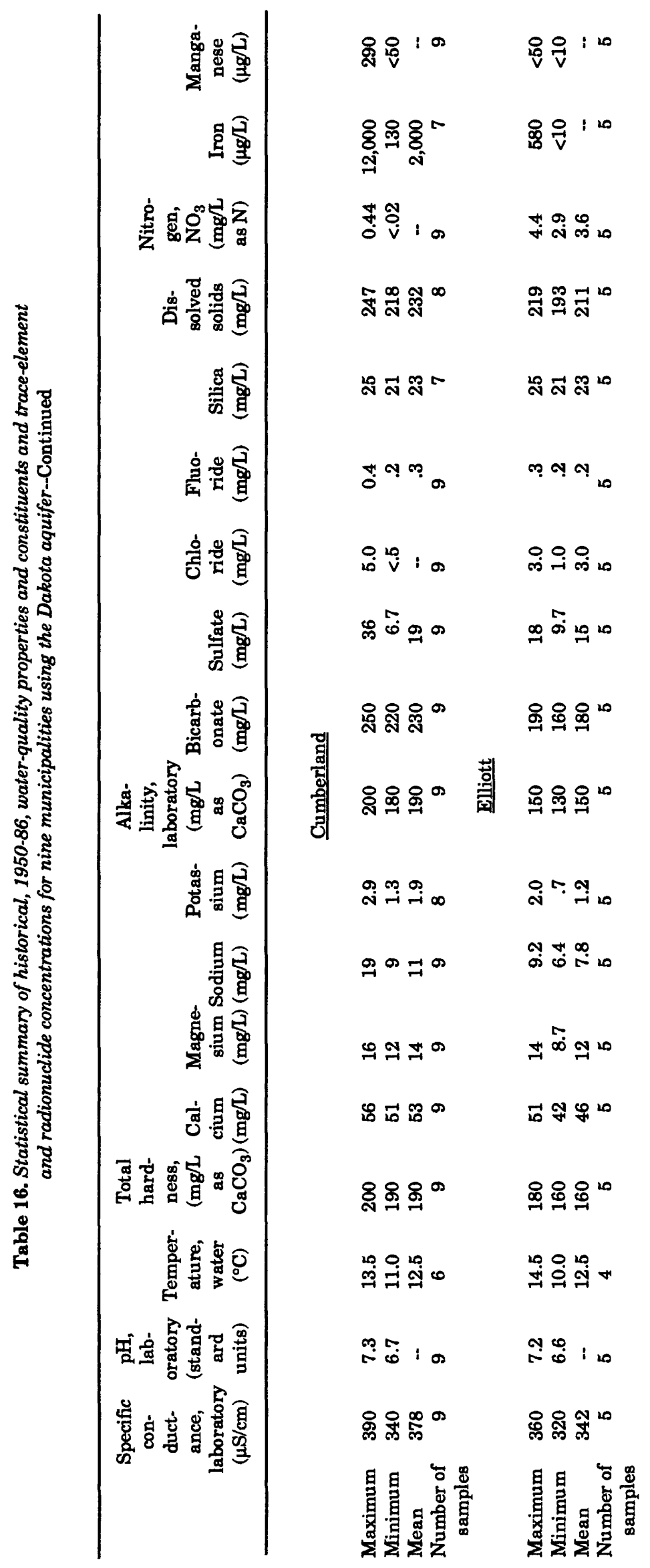




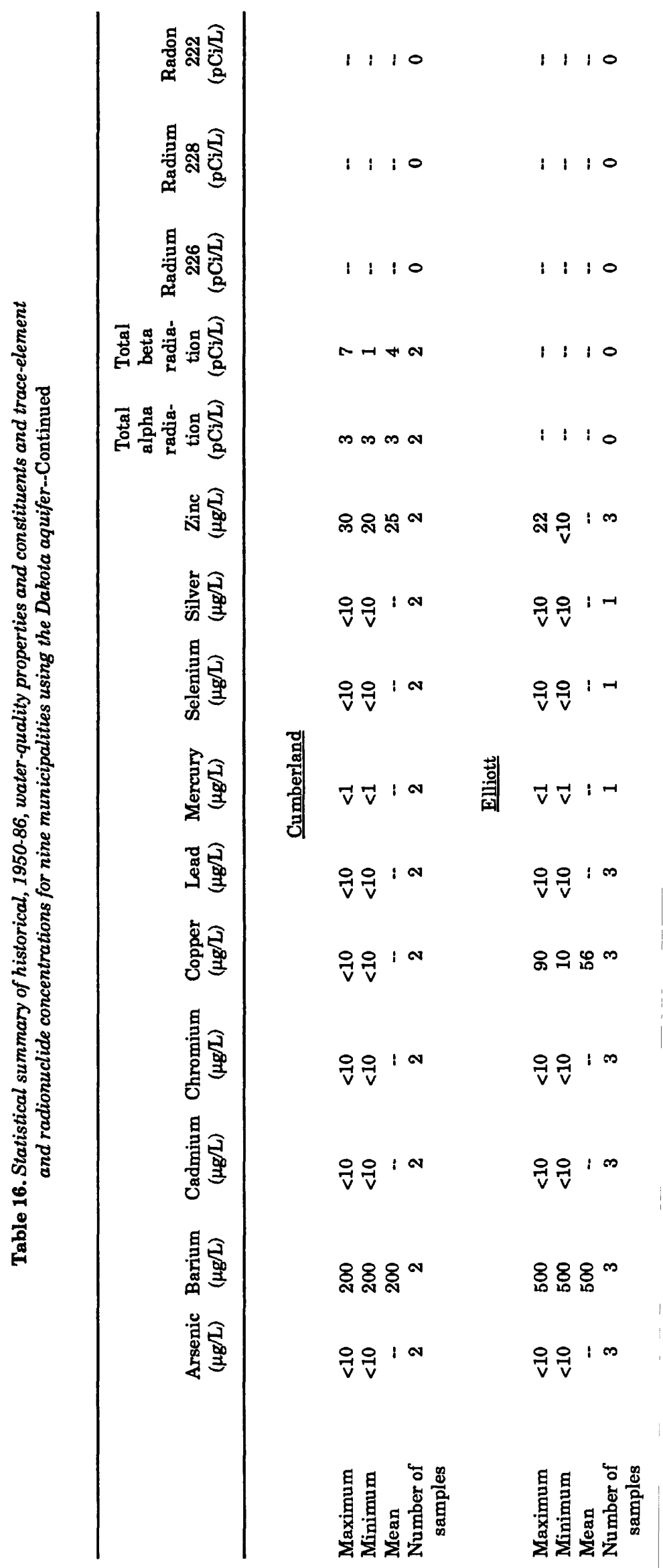




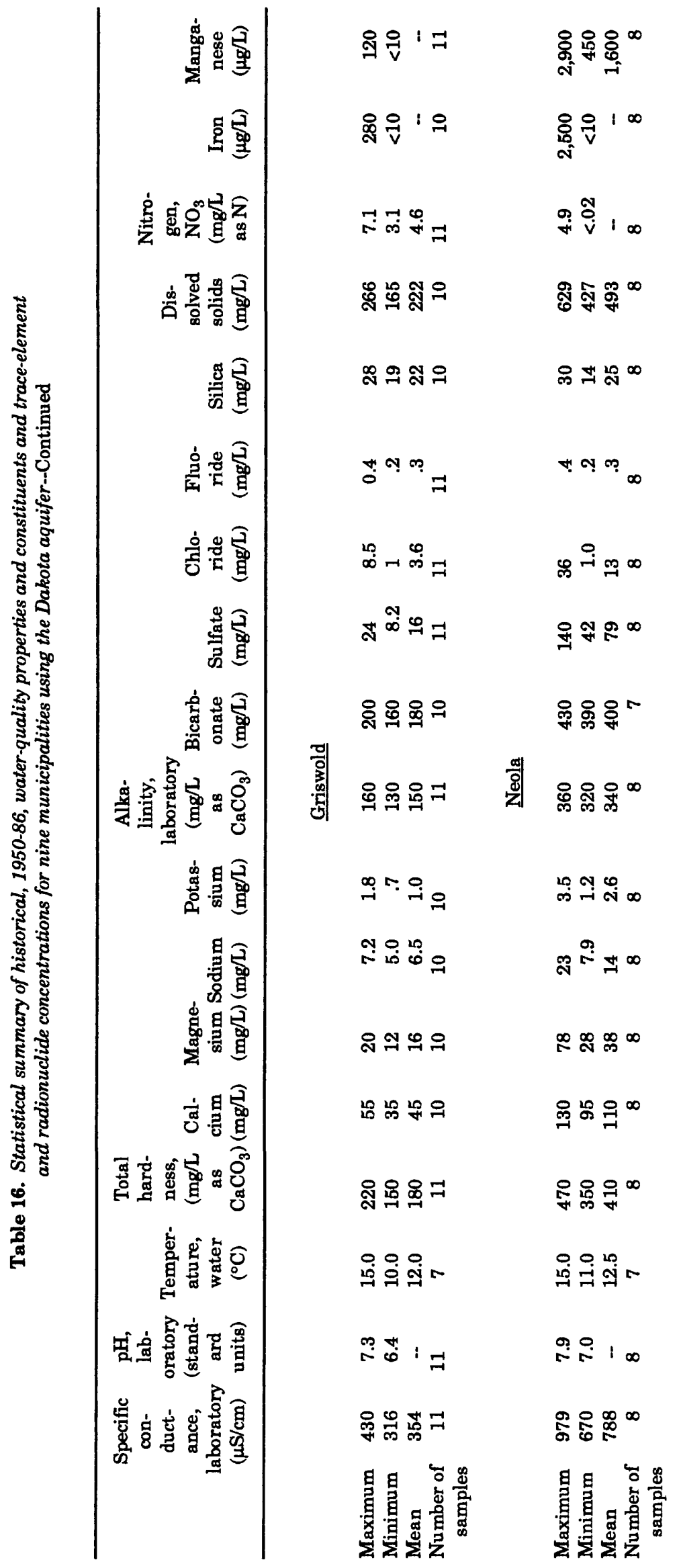




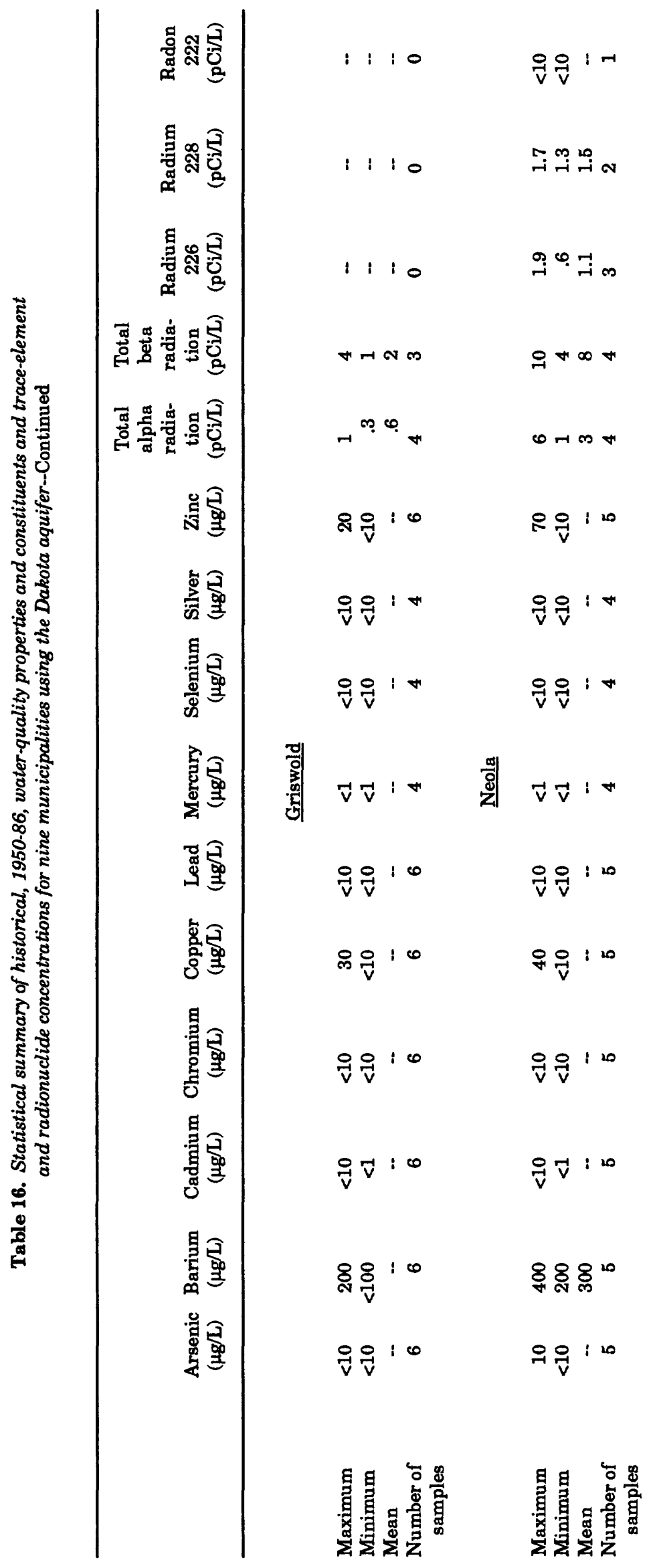




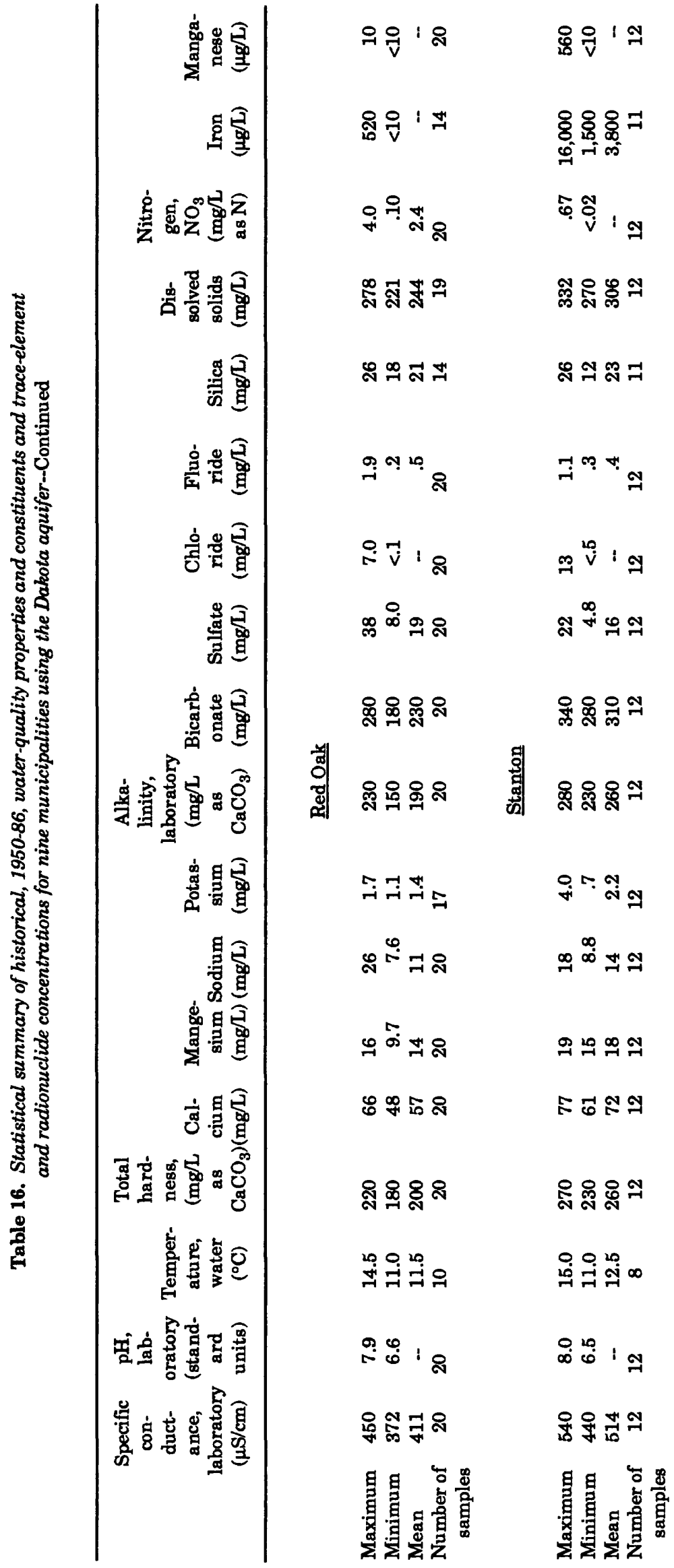




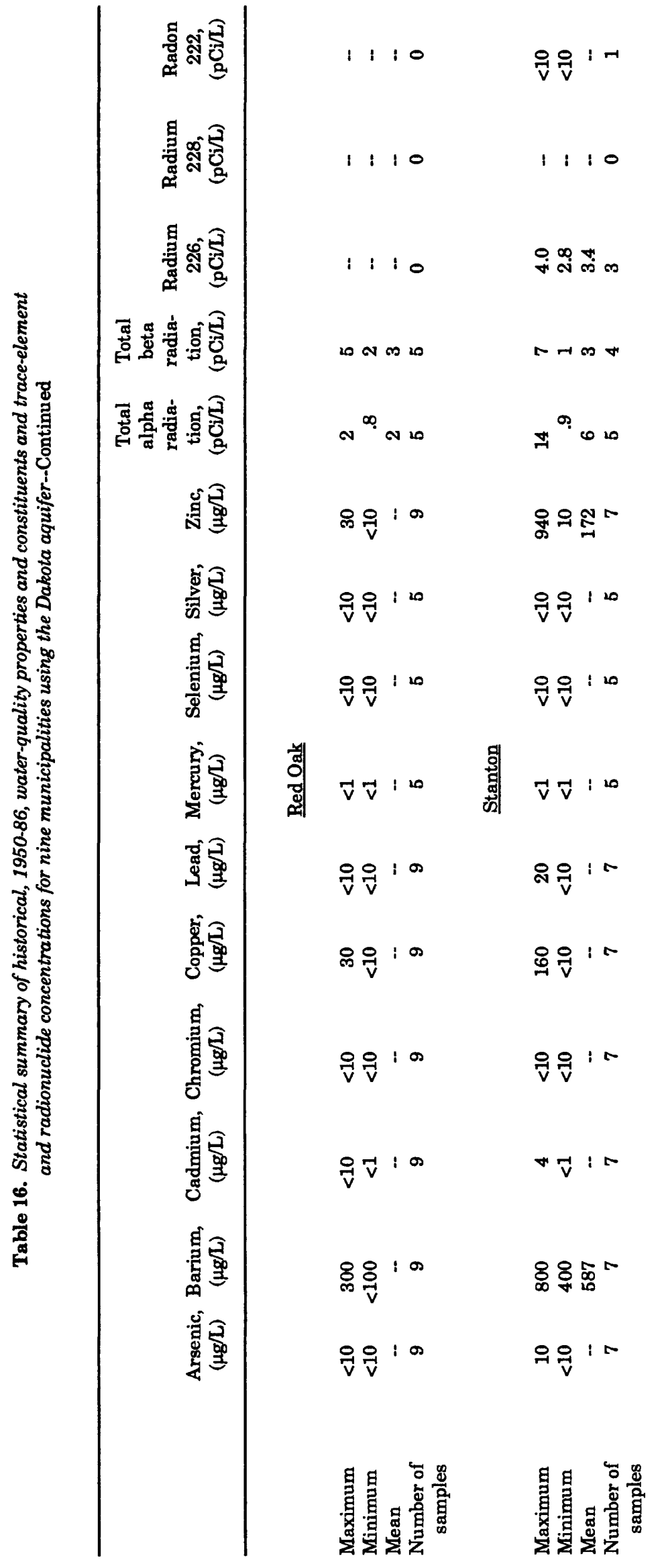




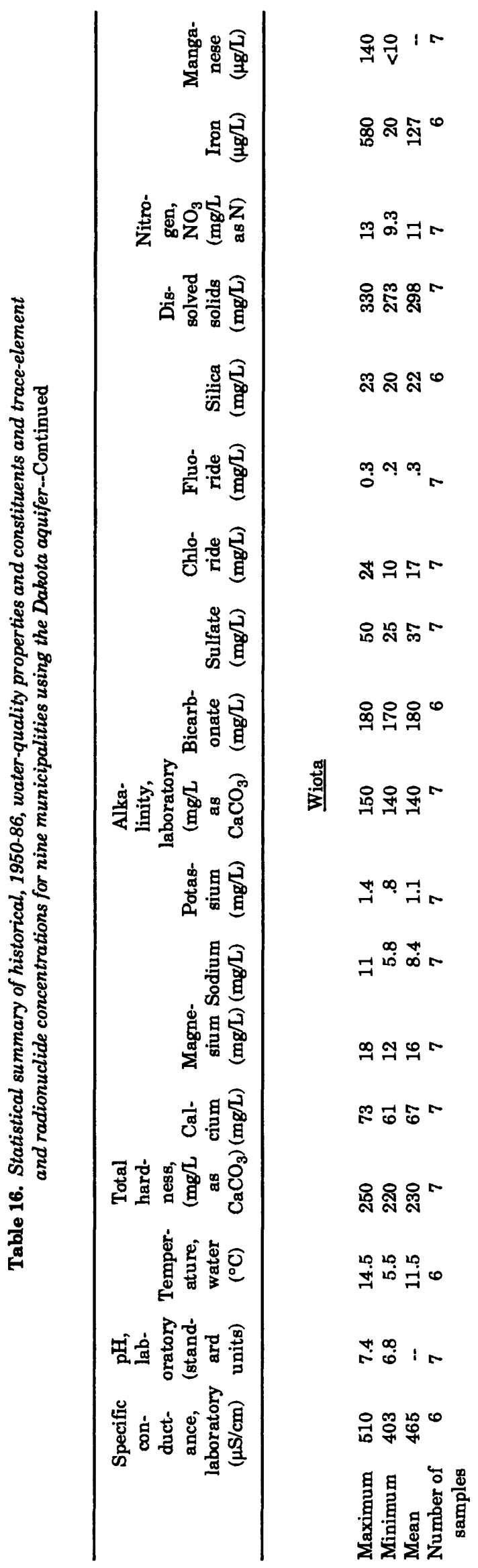




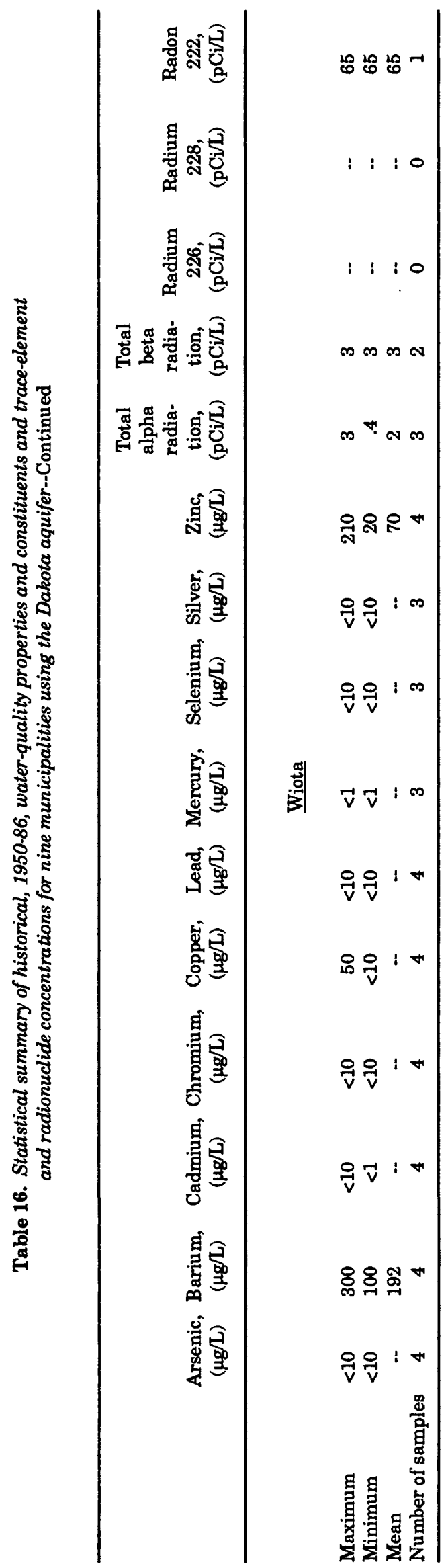


Table 17. Water use by category, 1984

[Mgal/d, million gallons per day; gal/d, gallons per day; --, no estimate; NA, not applicable]

\begin{tabular}{|c|c|c|c|c|c|c|c|}
\hline \multirow[b]{2}{*}{$\begin{array}{l}\text { County } \\
\text { and } \\
\text { source } \\
\text { of } \\
\text { water }\end{array}$} & \multirow[b]{2}{*}{ Population } & \multicolumn{4}{|c|}{ Municipal and rural systems } & \multirow[b]{2}{*}{$\begin{array}{c}\text { Estimated } \\
\text { domestic } \\
\text { rural } \\
\text { use } \\
(\mathrm{Mgal} / \mathrm{d})\end{array}$} & \multirow[b]{2}{*}{$\begin{array}{c}\text { Total } \\
\text { domestic } \\
\text { average } \\
\text { use } \\
(\mathrm{Mgal} / \mathrm{d})\end{array}$} \\
\hline & & $\begin{array}{c}\text { Population } \\
\text { served }\end{array}$ & $\begin{array}{c}\text { Percent } \\
\text { of } \\
\text { county } \\
\text { population }\end{array}$ & $\begin{array}{c}\text { Average } \\
\text { use } \\
\text { (Mgal/d) }\end{array}$ & $\begin{array}{c}\text { Maximum } \\
\text { use } \\
\text { (Mgal/d) }\end{array}$ & & \\
\hline Adair & 9,509 & 6,230 & 65.5 & 0.560 & 1.091 & 0.328 & 0.888 \\
\hline All aquifers & & 3,571 & 37.6 & .314 & .648 & .328 & .642 \\
\hline Alluvial aquifers & & 998 & 10.5 & .070 & .177 & - & .070 \\
\hline Adams & 5,731 & 2,473 & 43.2 & .282 & .596 & .326 & .608 \\
\hline All aquifers & & 534 & 9.3 & .032 & .098 & .326 & .358 \\
\hline Alluvial aquifers & & 534 & 9.3 & .032 & .098 & -- & .032 \\
\hline Cass & 16,932 & 11,827 & 69.8 & 1.458 & 2.335 & .511 & 1.969 \\
\hline All aquifers & & 11,827 & 69.8 & 1.458 & 2.335 & .511 & 1.969 \\
\hline Alluvial aquifers & & 680 & 4.0 & .060 & .170 & - & .060 \\
\hline Fremont & 9,401 & 5,800 & 61.7 & .757 & 1.837 & .360 & 1.117 \\
\hline All aquifers & & 3,564 & 37.9 & .685 & 1.234 & .360 & 1.045 \\
\hline Alluvial aquifers & & 3,564 & 37.9 & .685 & 1.234 & -- & .685 \\
\hline Mills & 13,406 & 8,279 & 61.8 & .973 & 3.585 & .513 & 1.486 \\
\hline All aquifers & & 2,488 & 18.6 & .973 & .695 & .513 & 1.486 \\
\hline Alluvial aquifers & & 1,986 & 14.8 & .897 & .433 & -- & .897 \\
\hline Montgomery & 13,413 & 9,602 & 71.6 & 1.474 & 2.829 & .381 & 1.855 \\
\hline All aquifers & & 9,484 & 70.7 & 1.464 & 2.829 & .381 & 1.845 \\
\hline Alluvial aquifers & & 1,681 & 12.5 & .276 & .481 & -- & .276 \\
\hline Page & 19,063 & 16,993 & 89.1 & 1.906 & 3.557 & .207 & 2.113 \\
\hline All aquifers & & 8,079 & 42.4 & 1.002 & 1.879 & .207 & 1.209 \\
\hline Alluvial aquifers & & 8,079 & 42.4 & 1.002 & 1.879 & -- & 1.002 \\
\hline Pottawattamie & 86,561 & 68,574 & 79.2 & 9.295 & 18.176 & 1.799 & 11.094 \\
\hline All aquifers & & 8,582 & 9.9 & 4.945 & 2.577 & 1.799 & 6.744 \\
\hline Alluvial aquifers & & 4,612 & 5.3 & 4.584 & 1.566 & -- & 4.584 \\
\hline Taylor & 8,353 & 4,831 & $\mathbf{5 7 . 8}$ & .544 & .874 & .352 & .896 \\
\hline All aquifers & & 618 & 7.4 & .037 & .063 & .352 & .389 \\
\hline Alluvial aquifers & & 338 & 4.0 & .022 & .048 & -- & .022 \\
\hline \multicolumn{8}{|l|}{ TOTAL: } \\
\hline All counties & 182,369 & 134,609 & 73.8 & 17.249 & 34.880 & 4.777 & 22.026 \\
\hline All aquifers & & 48,747 & 26.7 & 10.910 & 12.358 & 4.777 & 15.687 \\
\hline Alluvial aquifers & & 22,472 & 12.3 & 7.628 & 6.086 & -- & 7.628 \\
\hline
\end{tabular}


Table 17. Water use by category, 1984--Continued

\begin{tabular}{|c|c|c|c|c|c|c|c|}
\hline County & $\begin{array}{c}\text { Total } \\
\text { livestock } \\
\text { (Mgal/d) }\end{array}$ & $\begin{array}{l}\text { Irrigation, } \\
\text { permitted, } \\
\text { ground } \\
\text { water } \\
\text { (Mgal/d) }\end{array}$ & $\begin{array}{l}\text { Irrigation, } \\
\text { permitted, } \\
\text { surface } \\
\text { water } \\
(\mathrm{Mgal} / \mathrm{d})\end{array}$ & $\begin{array}{l}\text { Industrial } \\
\text { permitted, } \\
\text { ground } \\
\text { water } \\
\text { (Mgal/d) }\end{array}$ & $\begin{array}{l}\text { Industrial } \\
\text { permitted, } \\
\text { surface } \\
\text { water } \\
\text { (Mgal/d) }\end{array}$ & $\begin{array}{l}\text { Feedlots, } \\
\text { permitted, } \\
\text { ground } \\
\text { water } \\
(\mathrm{Mgal} / \mathrm{d})\end{array}$ & $\begin{array}{c}\text { Feedlots, } \\
\text { permitted } \\
\text { surface } \\
\text { water } \\
(\mathrm{Mgal} / \mathrm{d})\end{array}$ \\
\hline Adair & 1.708 & 0 & 0 & 0 & 3.655 & 0 & 0 \\
\hline All aquifers & -. & 0 & NA & 0 & NA & 0 & NA \\
\hline Alluvial aquifers & - & 0 & NA & 0 & NA & 0 & NA \\
\hline Adams & .988 & 0 & 0 & 0 & 2.116 & 0 & 0 \\
\hline All aquifers & -- & 0 & NA & 0 & NA & 0 & NA \\
\hline Alluvial aquifers & -- & 0 & NA & 0 & NA & 0 & NA \\
\hline Cass & 1.264 & .521 & 1.435 & 0 & 4.564 & 0 & 0 \\
\hline All aquifers & -- & .521 & NA & 0 & NA & 0 & NA \\
\hline Alluvial aquifers & -- & 0 & NA & 0 & NA & 0 & NA \\
\hline Fremont & .681 & 6.725 & 1.583 & .241 & .089 & .144 & 0 \\
\hline All aquifers & -- & 6.725 & NA & .241 & NA & .144 & NA \\
\hline Alluvial aquifers & -- & 6.725 & NA & .241 & NA & 0 & NA \\
\hline Mills & .661 & 6.075 & 1.039 & 0 & .313 & .145 & 0 \\
\hline All aquifers & -- & 6.075 & NA & 0 & NA & .145 & NA \\
\hline Alluvial aquifers & -- & 6.075 & NA & 0 & NA & .145 & NA \\
\hline Montgomery & .881 & 0 & .193 & 0 & .295 & .085 & .150 \\
\hline All aquifers & -- & 0 & NA & 0 & NA & .085 & NA \\
\hline Alluvial aquifers & -- & 0 & NA & 0 & NA & .085 & NA \\
\hline Page & 1.062 & 0.914 & 1.192 & 0 & 4.104 & 0 & 0 \\
\hline All aquifers & -- & .914 & NA & 0 & NA & 0 & NA \\
\hline Alluvial aquifers & -- & .914 & NA & 0 & NA & 0 & NA \\
\hline Pottawattamie & 1.983 & 6.056 & 1.179 & 3.534 & 3.096 & .299 & 0 \\
\hline All aquifers & -- & 6.056 & NA & 3.534 & NA & .299 & NA \\
\hline Alluvial aquifers & -- & 6.056 & NA & 3.534 & NA & 0 & NA \\
\hline Taylor & 1.051 & 0 & .006 & 0 & .045 & 0 & 0 \\
\hline All aquifers & -- & 0 & NA & 0 & NA & 0 & NA \\
\hline Alluvial aquifers & -- & 0 & NA & 0 & NA & 0 & NA \\
\hline \multicolumn{8}{|l|}{ TOTAL: } \\
\hline All counties & 10.285 & 20.291 & 6.627 & 3.775 & 18.278 & .673 & .150 \\
\hline All aquifers & -- & 20.291 & NA & 3.775 & NA & .673 & NA \\
\hline Alluvial aquifers & -- & 19.609 & NA & 3.775 & NA & .230 & NA \\
\hline
\end{tabular}


Table 17. Water use by category, 1984--Continued

\begin{tabular}{|c|c|c|c|c|c|}
\hline County & $\begin{array}{l}\text { Miscellaneous } \\
\text { permitted, } \\
\text { ground water } \\
(\mathrm{Mgal} / \mathrm{d})\end{array}$ & $\begin{array}{l}\text { Miscellaneous } \\
\text { permitted, } \\
\text { surface water } \\
(\mathrm{Mgal} / \mathrm{d})\end{array}$ & $\begin{array}{c}\text { Total, } \\
\text { permitted use } \\
(\mathrm{Mgal} / \mathrm{d})\end{array}$ & $\begin{array}{l}\text { Total permitted, } \\
\text { without } \\
\text { feedlots } \\
\text { (Mgal/d) }\end{array}$ & $\begin{array}{c}\text { Total } \\
\text { water use } \\
\text { (Mgal/d) }\end{array}$ \\
\hline Adair & 0 & 0 & 3.656 & 3.656 & 6.258 \\
\hline All aquifers & 0 & NA & 0 & 0 & ${ }^{2} .642$ \\
\hline Alluvial aquifers & 0 & NA & 0 & 0 & ${ }^{2} .070$ \\
\hline Adams & 0 & 0 & 2.116 & 2.116 & 3.712 \\
\hline All aquifers & 0 & NA & 0 & 0 & ${ }^{2} .358$ \\
\hline Alluvial aquifers & 0 & NA & 0 & 0 & ${ }^{2} .032$ \\
\hline Cass & 0 & 0 & 6.520 & 6.520 & 9.753 \\
\hline All aquifers & 0 & NA & .521 & .521 & 22.490 \\
\hline Alluvial aquifers & 0 & NA & 0 & 0 & 2.060 \\
\hline Fremont & .947 & 4.192 & 13.921 & 13.777 & 15.575 \\
\hline All aquifers & .947 & NA & 8.057 & 7.913 & 28.958 \\
\hline Alluvial aquifers & .947 & NA & 7.752 & 7.752 & 28.437 \\
\hline Mills & .108 & .002 & 7.682 & 7.537 & 9.684 \\
\hline All aquifers & .108 & NA & 6.328 & 6.183 & 27.669 \\
\hline Alluvial aquifers & .108 & NA & 6.328 & 6.183 & 27.080 \\
\hline Montgomery & 0 & 0 & .723 & .488 & 3.224 \\
\hline All aquifers & 0 & NA & .085 & 0 & ${ }^{2} 1.845$ \\
\hline Alluvial aquifers & 0 & NA & .085 & 0 & 2.276 \\
\hline Page & 0.055 & 0 & 6.265 & 6.265 & 9.440 \\
\hline All aquifers & .055 & NA & .969 & .969 & 22.178 \\
\hline Alluvial aquifers & .055 & NA & .969 & .969 & 21.971 \\
\hline Pottawattamie & .060 & 5.112 & 19.336 & 19.037 & 32.114 \\
\hline All aquifers & .060 & NA & 9.949 & 9.650 & ${ }^{2} 16.394$ \\
\hline Alluvial aquifers & .060 & NA & 9.650 & 9.650 & ${ }^{2} 14.234$ \\
\hline Taylor & 0 & 0 & .051 & .051 & 1.998 \\
\hline All aquifers & 0 & NA & 0 & 0 & ${ }^{2} .389$ \\
\hline Alluvial aquifers & 0 & NA & 0 & 0 & ${ }^{2} .022$ \\
\hline \multicolumn{6}{|l|}{ TOTAL: } \\
\hline All counties & 1.170 & 9.306 & 60.270 & 59.447 & 91.758 \\
\hline All aquifers & 1.170 & NA & 25.909 & 25.236 & ${ }^{2} 40.923$ \\
\hline Alluvial aquifers & 1.154 & NA & 24.768 & 24.538 & ${ }^{2} 32.166$ \\
\hline
\end{tabular}

${ }^{1}$ Domestic rural use estimated as 100 gallons per day per capita for those not served by water systems.

${ }^{2}$ Does not include livestock use. 
Table 18. Water source and use for municipal and rural-water systems in southwest Iowa

$$
\text { [Mgal/d, million gallons per day; --, no data] }
$$

\begin{tabular}{cccccc}
\hline $\begin{array}{c}\text { Municipal } \\
\text { water } \\
\text { use }\end{array}$ & Water source & $\begin{array}{c}\text { Source } \\
\text { (percent } \\
\text { of total) }\end{array}$ & $\begin{array}{c}\text { Population } \\
\text { served } \\
\text { during 1980 }\end{array}$ & $\begin{array}{c}\text { Average use } \\
\text { during 1984 } \\
(\mathrm{Mgal} / \mathrm{d})\end{array}$ & $\begin{array}{c}\text { Maximum use } \\
\text { during 1984 } \\
(\mathrm{Mgal} / \mathrm{d})\end{array}$ \\
\hline
\end{tabular}

\begin{tabular}{|c|c|c|c|c|c|}
\hline \multicolumn{6}{|c|}{ Adair County } \\
\hline \multirow[t]{2}{*}{ Adair } & $\begin{array}{l}\text { Cambrian/Ordovician } \\
\text { aquifer }\end{array}$ & 90 & 883 & 0.094 & 0.181 \\
\hline & $\begin{array}{l}\text { Silurian/Devonian } \\
\text { aquifer }\end{array}$ & 10 & -- & -- & -- \\
\hline Bridgewater & $\begin{array}{l}\text { West Fork Middle } \\
\text { Nodaway River } \\
\text { alluvium }\end{array}$ & 100 & 233 & .019 & .096 \\
\hline \multirow[t]{2}{*}{ Fontanelle } & $\begin{array}{l}\text { West Fork Middle } \\
\text { Nodaway River } \\
\text { alluvium }\end{array}$ & 95 & 805 & .054 & .085 \\
\hline & Albany channel & 5 & -. & -- & -- \\
\hline Greenfield & $\begin{array}{l}\text { Lake Nodaway and } \\
\text { Lake Greenfield }\end{array}$ & 100 & 2,243 & .203 & .388 \\
\hline Orient & Lake Orient & 100 & 416 & .044 & .055 \\
\hline \multirow[t]{2}{*}{ Stuart } & $\begin{array}{l}\text { Cambrian/Ordovician } \\
\text { aquifer }\end{array}$ & 90 & 1,650 & .147 & .286 \\
\hline & $\begin{array}{l}\text { Inter-till sand } \\
\text { and gravel aquifer }\end{array}$ & 10 & - & -- & -- \\
\hline \multicolumn{6}{|c|}{ Adams County } \\
\hline Corning & $\begin{array}{l}\text { Lake Binder, city } \\
\text { reservoir, and } \\
\text { Lake Icaria }\end{array}$ & 100 & 1,939 & .250 & .498 \\
\hline Nodaway & $\begin{array}{l}\text { East Nodaway } \\
\text { River alluvium }\end{array}$ & 100 & 185 & .011 & .048 \\
\hline Prescott & $\begin{array}{l}\text { East Nodaway } \\
\text { River alluvium }\end{array}$ & 100 & 349 & .021 & .050 \\
\hline \multicolumn{6}{|c|}{ Cass County } \\
\hline Anita & Dakota aquifer & 100 & 1,153 & .139 & .239 \\
\hline Atlantic & Dakota aquifer & 100 & 7,789 & .919 & 1.35 \\
\hline \multirow[t]{2}{*}{ Cumberland } & Dakota aquifer & 75 & 351 & .026 & .070 \\
\hline & $\begin{array}{l}\text { Inter-till sand and } \\
\text { gravel aquifer }\end{array}$ & 25 & -- & -- & -- \\
\hline Griswold & Dakota aquifer & 100 & 1,176 & .250 & .400 \\
\hline Lewis & Glacial drift aquifer & 100 & 497 & .042 & .080 \\
\hline Marne & Camp Creek alluvium & 100 & 162 & .013 & .018 \\
\hline Massena & $\begin{array}{l}\text { West Nodaway River } \\
\text { alluvium }\end{array}$ & 100 & 518 & .047 & .152 \\
\hline Wiota & Dakota aquifer & 100 & 181 & .023 & .025 \\
\hline
\end{tabular}


Table 18. Water source and use for municipal and rural-water systems in southwest lowa--Continued

\begin{tabular}{cccccc}
\hline $\begin{array}{c}\text { Municipal } \\
\text { water } \\
\text { use }\end{array}$ & Water source & $\begin{array}{c}\text { Source } \\
\text { (percent } \\
\text { of total) }\end{array}$ & $\begin{array}{c}\text { Population } \\
\text { served } \\
\text { during 1980 }\end{array}$ & $\begin{array}{c}\text { Average use } \\
\text { during 1984 } \\
(\mathrm{Mgal} / \mathrm{d})\end{array}$ & $\begin{array}{c}\text { Maximum use } \\
\text { during 1984 } \\
(\mathrm{Mgal} / \mathrm{d})\end{array}$ \\
\hline
\end{tabular}

\begin{tabular}{|c|c|c|c|c|c|}
\hline \multicolumn{6}{|c|}{ Fremont County } \\
\hline Farragut & $\begin{array}{l}\text { East Nishnabotna } \\
\text { River alluvium }\end{array}$ & 100 & 603 & 0.055 & 0.404 \\
\hline Hamburg & $\begin{array}{l}\text { Missouri River } \\
\text { alluvium }\end{array}$ & 100 & 1,597 & .240 & .475 \\
\hline Imogene & $\begin{array}{l}\text { Nodaway River; } \\
\text { from Page I Rural } \\
\text { Water Association }\end{array}$ & 100 & 188 & .052 & -- \\
\hline Randolph & $\begin{array}{l}\text { West Nishnabotna } \\
\text { River alluvium }\end{array}$ & 100 & 223 & .037 & .167 \\
\hline Riverton & $\begin{array}{l}\text { East Nishnabotna } \\
\text { River alluvium }\end{array}$ & 100 & 342 & .006 & .103 \\
\hline Sidney & $\begin{array}{l}\text { West Nishnabotna } \\
\text { River alluvium }\end{array}$ & 100 & 1,308 & .184 & .360 \\
\hline Tabor & $\begin{array}{l}\text { West Nishnabotna } \\
\text { River alluvium }\end{array}$ & 100 & 1,088 & .125 & .200 \\
\hline Thurman & $\begin{array}{l}\text { Missouri River } \\
\text { alluvium }\end{array}$ & 100 & 221 & .038 & .110 \\
\hline $\begin{array}{l}\text { Page I Rural } \\
\text { Water }\end{array}$ & $\begin{array}{l}\text { Nodaway River; } \\
\text { from Clarinda }\end{array}$ & 100 & 230 & .020 & -- \\
\hline \multicolumn{6}{|c|}{ Mills County } \\
\hline Emerson & $\begin{array}{l}\text { Basal sand and } \\
\text { gravel aquifer }\end{array}$ & 100 & 502 & .076 & .262 \\
\hline Glenwood & $\begin{array}{l}\text { Missouri River } \\
\text { alluvium }\end{array}$ & 100 & 5,280 & .711 & 2.89 \\
\hline Hastings & $\begin{array}{l}\text { West Nishnabotna } \\
\text { River alluvium }\end{array}$ & 100 & 215 & .010 & .065 \\
\hline Henderson & $\begin{array}{l}\text { West Nishnabotna } \\
\text { River alluvium }\end{array}$ & 100 & 236 & .022 & .103 \\
\hline Malvern & $\begin{array}{l}\text { West Nishnabotna } \\
\text { River alluvium }\end{array}$ & 90 & 1,244 & .123 & .229 \\
\hline & Silver Creek alluvium & 10 & -- & -- & -- \\
\hline $\begin{array}{l}\text { Pacific } \\
\text { Junction }\end{array}$ & $\begin{array}{l}\text { Missouri River } \\
\text { alluvium; from Glenwood }\end{array}$ & 100 & 511 & -- & -- \\
\hline Silver City & Silver Creek alluvium & 100 & 291 & .031 & .036 \\
\hline \multicolumn{6}{|c|}{ Montgomery County } \\
\hline Elliott & $\begin{array}{l}\text { East Nishnabotna } \\
\text { River alluvium }\end{array}$ & 50 & 493 & .099 & .079 \\
\hline & Dakota aquifer & 50 & -- & -- & -- \\
\hline Red Oak & Dakota aquifer & 100 & 6,810 & 1.049 & 2.19 \\
\hline Stanton & Dakota aquifer & 100 & 747 & .089 & .120 \\
\hline Villisca & $\begin{array}{l}\text { West Nodaway } \\
\text { River alluvium }\end{array}$ & 100 & 1,434 & .226 & .441 \\
\hline
\end{tabular}


Table 18. Water source and use for municipal and rural-water systems in southwest Iowa--Continued

\begin{tabular}{cccccc}
\hline $\begin{array}{c}\text { Municipal } \\
\text { water } \\
\text { use }\end{array}$ & Water source & $\begin{array}{c}\text { Source } \\
\text { (percent } \\
\text { of total) }\end{array}$ & $\begin{array}{c}\text { Population } \\
\text { served } \\
\text { during 1980 }\end{array}$ & $\begin{array}{c}\text { Average use } \\
\text { during 1984 } \\
\text { (Mgal/d) }\end{array}$ & $\begin{array}{c}\text { Maximum use } \\
\text { during 1984 } \\
(\text { Mgal/d) }\end{array}$ \\
\hline
\end{tabular}

\section{Montgomery County--Continued}

$\begin{array}{llccc}\begin{array}{c}\text { Page I Rural } \\ \text { Water } \\ \text { Association }\end{array} & \begin{array}{l}\text { Nodaway River; } \\ \text { from Clarinda }\end{array} & 100 & 118 & 0.011 \\ & & & & \end{array}$

\section{Page County}

\begin{tabular}{|c|c|c|c|c|c|}
\hline Blanchard & Tarkio River alluvium & 100 & 101 & .007 & 0.030 \\
\hline Braddyville & $\begin{array}{l}\text { Nodaway River } \\
\text { alluvium }\end{array}$ & 100 & 199 & .016 & .06 \\
\hline Clarinda & Nodaway River & 100 & 5.458 & .625 & 1.68 \\
\hline Coin & $\begin{array}{l}\text { Nodaway River; } \\
\text { from Page I Rural } \\
\text { Water Association }\end{array}$ & 100 & 316 & -- & -- \\
\hline $\begin{array}{l}\text { College } \\
\text { Springs }\end{array}$ & $\begin{array}{l}\text { Inter-till sand } \\
\text { and gravel aquifer }\end{array}$ & 100 & 307 & .020 & \\
\hline Essex & $\begin{array}{l}\text { East Nishnabotna } \\
\text { River alluvium }\end{array}$ & 100 & 1,001 & .122 & \\
\hline Shambaugh & $\begin{array}{l}\text { West Nodaway } \\
\text { River alluvium }\end{array}$ & 100 & 197 & .014 & \\
\hline Shenandoah & $\begin{array}{l}\text { East Nishnabotna } \\
\text { River alluvium }\end{array}$ & 100 & 6,274 & .824 & 1.50 \\
\hline $\begin{array}{l}\text { Page I Rural } \\
\text { Water }\end{array}$ & $\begin{array}{l}\text { Nodaway River; } \\
\text { from Clarinda }\end{array}$ & 100 & 3,140 & .279 & -- \\
\hline
\end{tabular}

\section{Association}

\section{Pottawattamie County}

\begin{tabular}{|c|c|}
\hline Avoca & $\begin{array}{l}\text { West Nishnabotna } \\
\text { River alluvium }\end{array}$ \\
\hline Carson & $\begin{array}{l}\text { West Nishnabotna } \\
\text { River alluvium }\end{array}$ \\
\hline $\begin{array}{l}\text { Carter Lake } \\
\text { Council Bluffs }\end{array}$ & $\begin{array}{l}\text { from Omaha, Nebraska } \\
\text { Missouri River } \\
\text { Missouri River alluvium }\end{array}$ \\
\hline Crescent & Pigeon Creek alluvium \\
\hline Hancock & $\begin{array}{l}\text { West Nishnabotna } \\
\text { River alluvium }\end{array}$ \\
\hline Macedonia & $\begin{array}{l}\text { West Nishnabotna } \\
\text { River alluvium }\end{array}$ \\
\hline Minden & $\begin{array}{l}\text { Inter-till sand } \\
\text { and gravel aquifer }\end{array}$ \\
\hline Neola & $\begin{array}{l}\text { Dakota aquifer } \\
\text { Mosquito Creek alluvium }\end{array}$ \\
\hline Oakland & $\begin{array}{l}\text { West Nishnabotna } \\
\text { River alluvium } \\
\text { Silurian/Devonian } \\
\text { aquifer }\end{array}$ \\
\hline
\end{tabular}

$\begin{array}{rrrl}100 & 1,650 & .215 & .392 \\ 100 & 716 & .098 & .218 \\ 100 & 3,438 & .350 & 1.05 \\ 50 & 56,449 & 8.000 & 4.5 \\ 50 & -- & -- & - \\ 100 & 547 & .043 & .089 \\ 100 & 254 & .025 & .076 \\ 100 & & & .063 \\ & 279 & .009 & .063 \\ 100 & 419 & .038 & .088 \\ 93.3 & 839 & .093 & .154 \\ 6.7 & -- & .- & -.450 \\ 87.5 & 1,552 & .156 & .450\end{array}$


Table 18. Water source and use for municipal and rural-water systems in southwest lowa--Continued

\begin{tabular}{|c|c|c|c|c|c|}
\hline $\begin{array}{l}\text { Municipal } \\
\text { water } \\
\text { use }\end{array}$ & Water source & $\begin{array}{l}\text { Source } \\
\text { (percent } \\
\text { of total) }\end{array}$ & $\begin{array}{c}\text { Population } \\
\text { served } \\
\text { during } 1980\end{array}$ & $\begin{array}{c}\text { Average use } \\
\text { during 1984 } \\
(\mathrm{Mgal} / \mathrm{d})\end{array}$ & $\begin{array}{c}\text { Maximum use } \\
\text { during } 1984 \\
(\mathrm{Mgal} / \mathrm{d})\end{array}$ \\
\hline \multicolumn{6}{|c|}{ Pottawattamie County--Continued } \\
\hline Treynor & $\begin{array}{l}\text { Fremont channel } \\
\text { aquifer }\end{array}$ & 100 & 981 & 0.076 & 0.225 \\
\hline \multirow[t]{3}{*}{ Underwood } & $\begin{array}{l}\text { Mosquito Creek } \\
\text { alluvium }\end{array}$ & 33.4 & 448 & .068 & .617 \\
\hline & $\begin{array}{l}\text { Inter-till sand } \\
\text { and gravel aquifer }\end{array}$ & 33.3 & - & -- & $-\cdot$ \\
\hline & $\begin{array}{l}\text { Basal sand and } \\
\text { gravel aquifer }\end{array}$ & 33.3 & - & -- & -- \\
\hline \multirow[t]{2}{*}{ Walnut } & Ordovician aquifer & 66.5 & 897 & .095 & .204 \\
\hline & $\begin{array}{l}\text { Cambrian/Ordovician } \\
\text { aquifer }\end{array}$ & 33.5 & -- & -- & - \\
\hline \multirow{3}{*}{$\begin{array}{l}\text { Shelby County } \\
\text { Rural Water } \\
\text { District }\end{array}$} & West Nishnabotna & 99.5 & 105 & .028 & .048 \\
\hline & $\begin{array}{l}\text { River alluvium } \\
\text { in Shelby County }\end{array}$ & & & & \\
\hline & $\begin{array}{l}\text { Mississippian aquifer } \\
\text { in Shelby County }\end{array}$ & .5 & -- & -- & -- \\
\hline \multicolumn{6}{|c|}{ Taylor County } \\
\hline Bedford & $\begin{array}{l}\text { East Fork One } \\
\text { Hundred and Two River, } \\
\text { East Branch One Hundred } \\
\text { and Two River, and Lake } \\
\text { of Three Fires }\end{array}$ & 100 & 1,692 & 0.176 & 0.383 \\
\hline Blockton & Albany channel aquifer & 100 & 280 & .015 & -- \\
\hline Clearfield & Platte River alluvium & 100 & 433 & .092 & .127 \\
\hline Conway & $\begin{array}{l}\text { East Fork One } \\
\text { Hundred and Two } \\
\text { River alluvium }\end{array}$ & 100 & 93 & .010 & .024 \\
\hline Gravity & $\begin{array}{l}\text { Middle Fork One } \\
\text { Hundred and Two } \\
\text { River alluvium }\end{array}$ & 100 & 245 & .012 & .024 \\
\hline Lenox & $\begin{array}{l}\text { East reservoir, } \\
\text { West reservoir, and } \\
\text { Mahary Lake }\end{array}$ & 100 & 1,338 & .188 & .203 \\
\hline New Market & $\begin{array}{l}\text { Nodaway River; from } \\
\text { Page I Rural Water } \\
\text { Association }\end{array}$ & 100 & 554 & .035 & .050 \\
\hline $\begin{array}{r}\text { Clearfield Rural } \\
\text { Water District }\end{array}$ & $\begin{array}{l}\text { Platte River } \\
\text { alluvium }\end{array}$ & 100 & 84 & .011 & .049 \\
\hline $\begin{array}{l}\text { Page I Rural } \\
\text { Water } \\
\text { Association }\end{array}$ & $\begin{array}{l}\text { Nodaway River; } \\
\text { from Clarinda }\end{array}$ & 100 & 112 & .010 & -. \\
\hline
\end{tabular}

